U.S. DEPARTMENT OF ENERGY

\title{
A STUDY OF ADVANCED TRAINING TECHNOLOGY: EMERGING ANSWERS TO TOUGH QUESTIONS
}

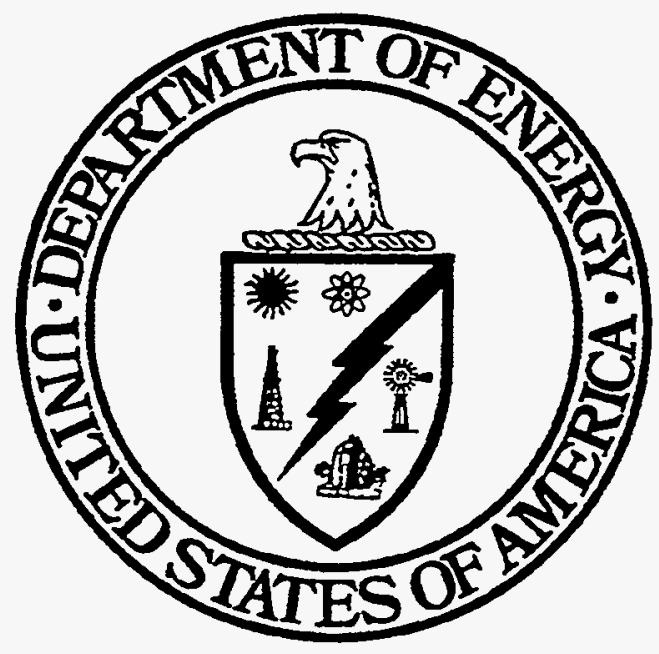

\section{U.S. Department of Energy}

Office of Training and Human Resource Development Washington, D.C. 20585

March 1, 1995 


\section{DISCLAIMER}

This report was prepared as an account of work sponsored by an agency of the United States Government. Neither the United States Government nor any agency thereof, nor any of their employees, make any warranty, express or implied, or assumes any legal liability or responsibility for the accuracy, completeness, or usefulness of any information, apparatus, product, or process disclosed, or represents that its use would not infringe privately owned rights. Reference herein to any specific commercial product, process, or service by trade name, trademark, manufacturer, or otherwise does not necessarily constitute or imply its endorsement, recommendation, or favoring by the United States Government or any agency thereof. The views and opinions of authors expressed herein do not necessarily state or reflect those of the United States Government or any agency thereof. 


\section{DISCLAIMER}

Portions of this document may be illegible in electronic image products. Images are produced from the best available original document. 


\begin{abstract}
This study reports the result of an extensive nationwide review of military, private sector, and other federal agencies and organizations that are implementing a wide variety of advanced training technologies. This report classifies the general categories of advanced training technologies found and provides an overview of each, including specific types and examples. In addition, the research findings present an organizational model for training development linking overall organizational maturity to readiness to implement specific kinds of advanced training technologies. It also presents proposed methods for selecting media, describes the organizations and the data gathered, and provides a summary of implementation success at each organization.
\end{abstract}

This study is organized as a set of five topics. Each topic raises a number of important questions and provides complete or emerging answers.

For organizations who have made advanced training selections, this study is a resource to benchmark their success with other organizations who have made similar selections. For new or developing training organizations, this study will help plan their future technology selections by comparing their level of organizational maturity to the documented experiences of similar organizations. 


\section{CONTENTS}

INTRODUCTION $\ldots \ldots \ldots \ldots \ldots \ldots \ldots \ldots \ldots \ldots \ldots \ldots \ldots \ldots \ldots \ldots \ldots$

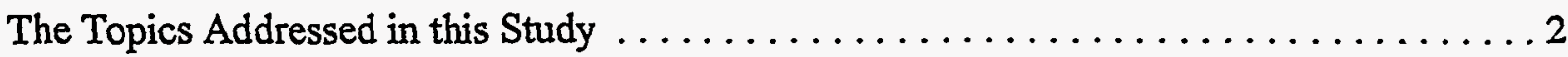

Topic 1. Availability and Considerations of ATT $\ldots \ldots \ldots \ldots \ldots \ldots \ldots \ldots \ldots$

Topic 2. Actual ATT Use and Lessons Learned . . . . . . . . . . . . . . . 4

Topic 3. Approaches for Selecting, Evaluating Cost-Benefit, and

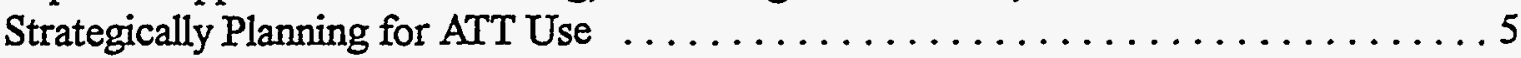

Topic 4. Current Status and Needs of DOE Relative to ATT $\ldots \ldots \ldots \ldots \ldots \ldots$

Topic 5. Final Recommendations . . . . . . . . . . . . . . .

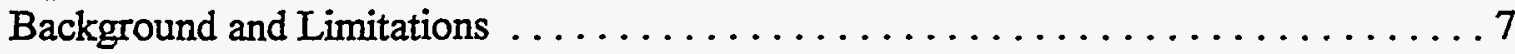

TOPIC 1. AVATLABLITY AND CONSTDERATIONS OF ATT $\ldots \ldots \ldots \ldots \ldots$

Subtopic 1.1 Overview of the Relevance of ATT to DOE . . . . . . . . . . . . 9

Subtopic 1.2 ATT Descriptions and Strengths and Limitations $\ldots \ldots \ldots \ldots \ldots \ldots$

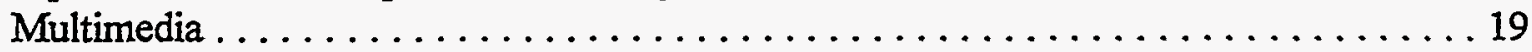

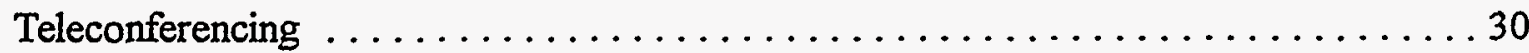

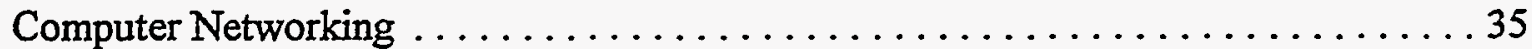

Courseware Applications . . . . . . . . . . . . . . . . . . 45

Subtopic 1.3 A Multimedia Taxonomy: A Guide to Understanding

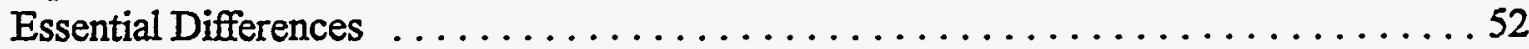

Subtopic 1.4 Logistic and Organizational Implications of

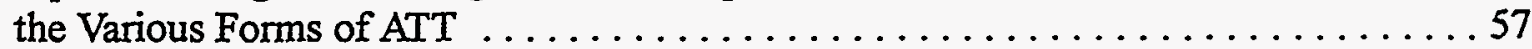

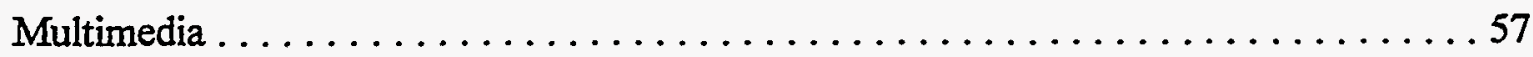

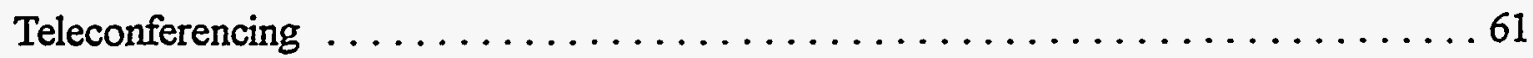

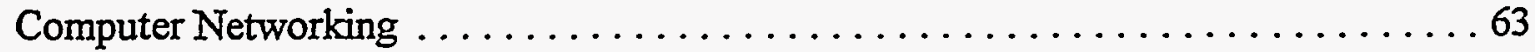

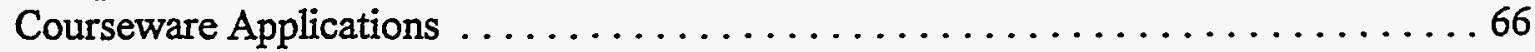

Subtopic 1.5 Suggested Approach for Learning about ATT

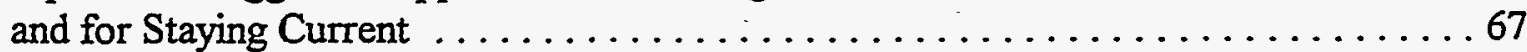

Subtopic 1.6 Emerging Technologies . . . . . . . . . . . . . . . . . 69

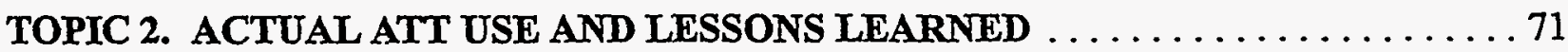

Subtopic 2.1 Use of ATT in Surveyed Organizations $\ldots \ldots \ldots \ldots \ldots \ldots \ldots \ldots \ldots \ldots$

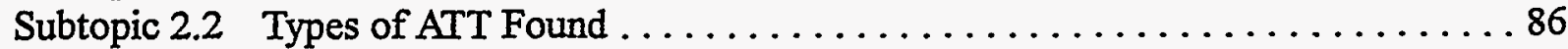

Subtopic 2.3 ATT-Related Organizational and

Implementation Strategies Observed $\ldots \ldots \ldots \ldots \ldots \ldots \ldots \ldots \ldots \ldots \ldots$

Subtopic 2.4 Exceptional ATT-Related Practices Observed . . . . . . . . . . . . 93

Subtopic 2.5 Summary of ATT-Related Lessons Learned $\ldots \ldots \ldots \ldots \ldots \ldots \ldots$

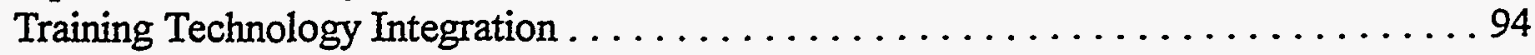

Contracting, Staffing, Logistics and Resource Management . . . . . . . . . 96

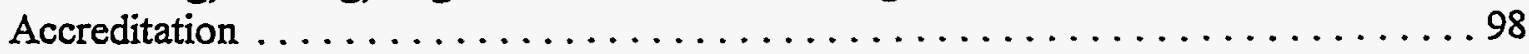

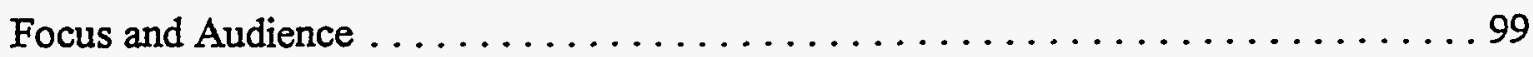

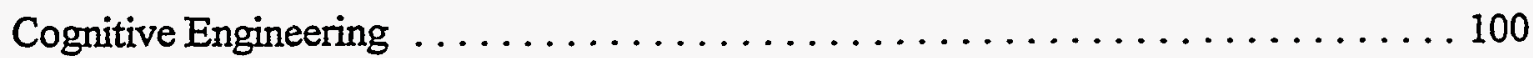

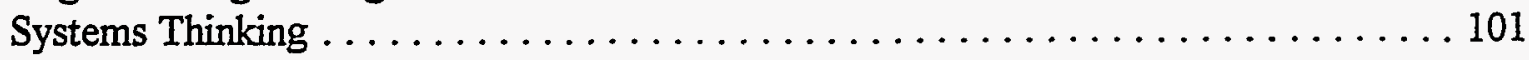


TOPIC 3. APPROACHES FOR SELECTING, EVALUATING COST-BENEFIT, AND

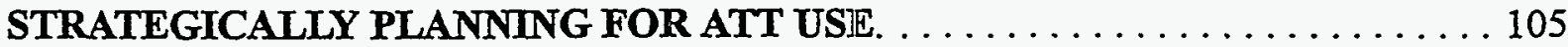

Subtopic 3.1 General Media Selection Considerations .................. 106

Subtopic 3.2 Adapting a Media-Method Selection Model for DOE ............ 111

Subtopic 3.3 Cost-Benefit Analysis for Assessing DOE's ATT Options . . . . . . . . . . 114

Subtopic 3.4 Strategic Tools to Assess DOE's Acceptance

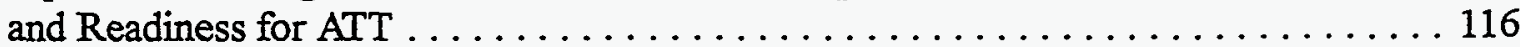

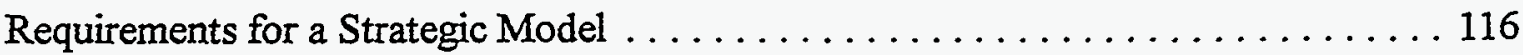

The Technology Cure-All . . . . . . . . . . . . . . . . . . . . . . . 117

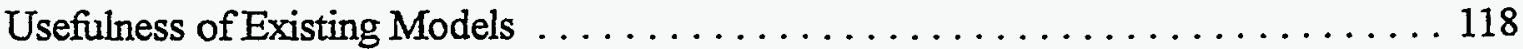

The Power of Maturity Models . ............................ 119

The General Acceptance and Readiness for Technology

Heuristic (GARTH) Model . . . . . . . . . . . . . . . . . . . . 120

Subtopic 3.5 Guidelines for Establishing a Centralized Function . . . . . . . . . 125

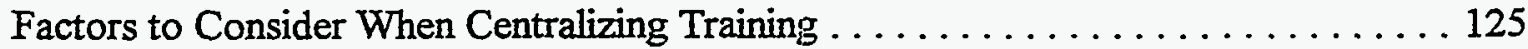

General Comments about Centralization . . . . . . . . . . . . . . . . 127

Generic Functions of a Central Training Organization

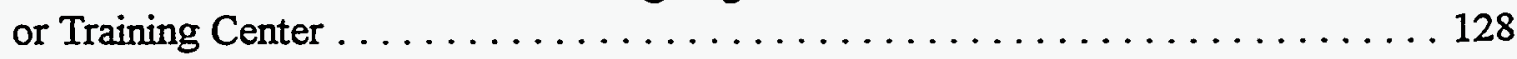

Generic Phases in Establishing a Central Training

Organization or Training Center ............................ 130

Subtopic 3.6 How PBT and SAT Relate to Discussed

Processes, Methods, and Models .......................... 134

TOPIC 4. CURRENT STATUS AND NEEDS OF DOE RELATTVE TO ATT . . . . . 135

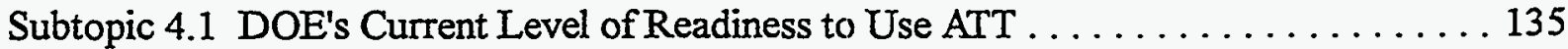

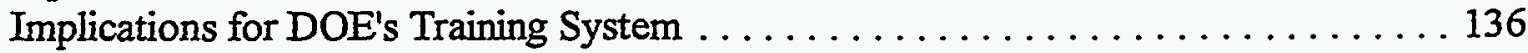

Possible Progression Scenarios for DOE's Training System ............. 136

Subtopic 4.2 DOE's Estimated Current and Comparative GARTH Level . . . . . . . . 139

Comparison of DOE with Other Organizations . . . . . . . . . . . . . . . 139

Implications of the GARTH Model for DOE $\ldots \ldots \ldots \ldots \ldots \ldots \ldots \ldots \ldots \ldots$

Subtopic 4.3 Diagnosis First, then Find ATT Solutions $\ldots \ldots \ldots \ldots \ldots \ldots \ldots \ldots \ldots$

Subtopic 4.4 The Status of DOE ATT Capabilities $\ldots \ldots \ldots \ldots \ldots \ldots \ldots \ldots \ldots \ldots \ldots \ldots$

Subtopic 4.5 Required Infrastructure Improvements to Facilitate ATT Usage . . . . . . 152

Subtopic 4.6 Organizational Changes Needed to Foster ATT $\ldots \ldots \ldots \ldots \ldots \ldots \ldots 152$

Subtopic 4.7 Availability of Cost and Benefit Data within DOE . . . . . . . . . 152

TOPIC 5. FINAL RECOMMENDATIONS $\ldots \ldots \ldots \ldots \ldots \ldots \ldots \ldots \ldots \ldots \ldots \ldots \ldots \ldots$

Subtopic 5.1 Specific Recommendations $\ldots \ldots \ldots \ldots \ldots \ldots \ldots \ldots \ldots \ldots \ldots \ldots \ldots \ldots \ldots \ldots \ldots$

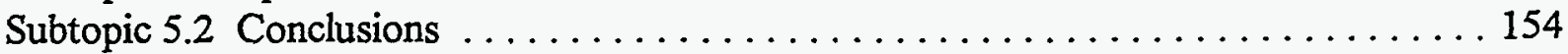

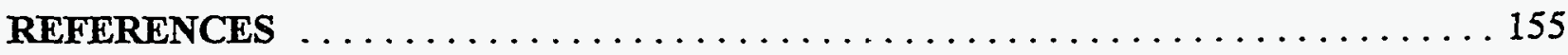

APPENDIX A: MEDIA SELECTION SURVEY INSTRUMENTS $\ldots \ldots \ldots \ldots \ldots$ A-1

APPENDIX B: SURVEY DATA MATRIX $\ldots \ldots \ldots \ldots \ldots \ldots \ldots \ldots \ldots \ldots$ B-1

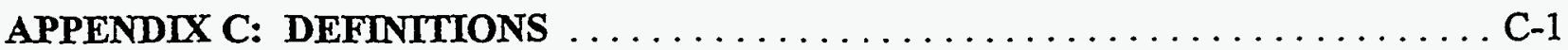




\section{FIGURES}

1. DOE progression scenarios: impossible dream, steady, or crisis . . . . . . . . . 138

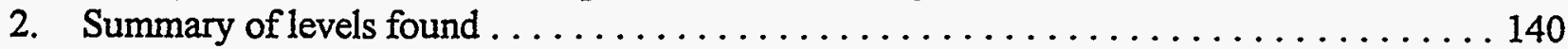

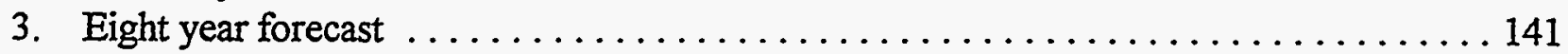

\section{TABLES}

1. Potential benefits from technology for training $\ldots \ldots \ldots \ldots \ldots \ldots \ldots \ldots \ldots$

2. Overview of the various advanced training technologies covered in this study . . . . . 14

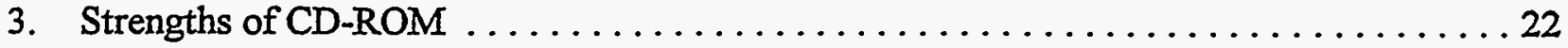

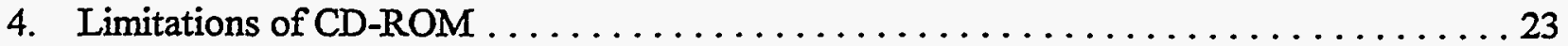

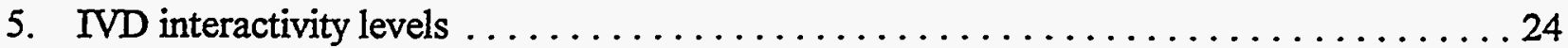

6. Application and instructional value of CD-ROM $\ldots \ldots \ldots \ldots \ldots \ldots \ldots \ldots \ldots \ldots \ldots \ldots \ldots$

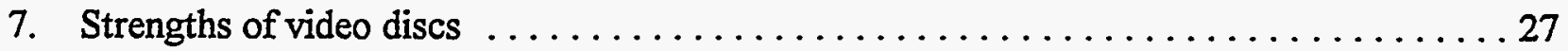

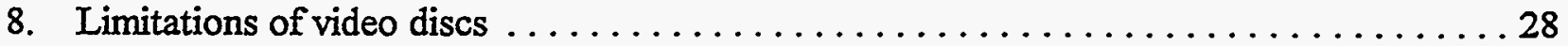

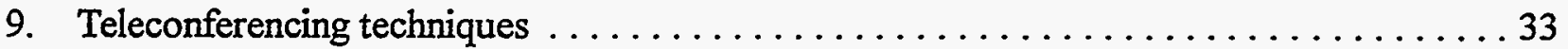

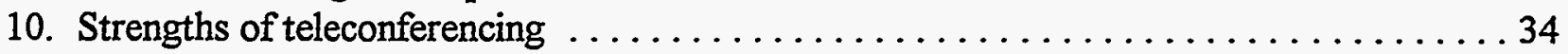

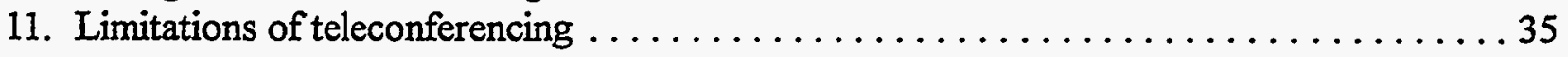

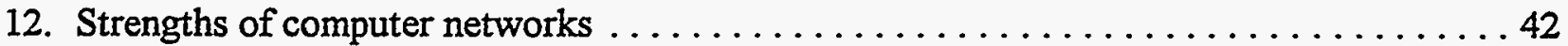

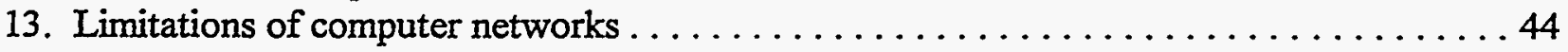

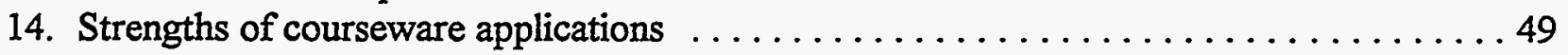

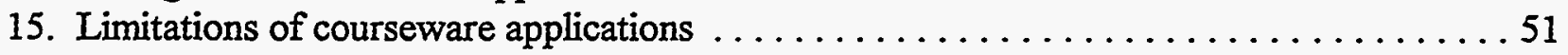

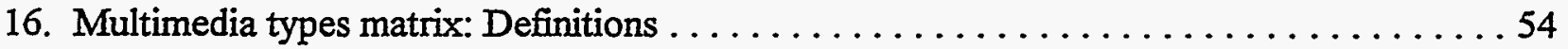

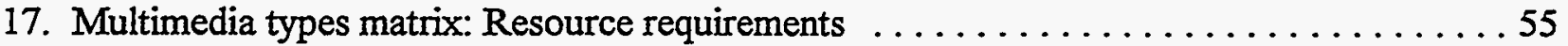

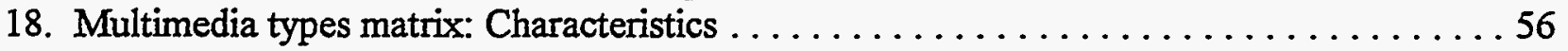

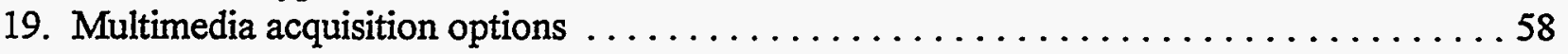

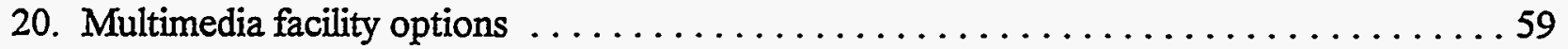

21. Six viable options for teleconferencing operations $\ldots \ldots \ldots \ldots \ldots \ldots \ldots \ldots \ldots \ldots \ldots$

22. Operational options for computer networking $\ldots \ldots \ldots \ldots \ldots \ldots \ldots \ldots \ldots \ldots \ldots \ldots \ldots \ldots \ldots$

23. Organizational and logistical considerations of courseware application options . . . . . 66

24. Suggestions for acquiring and maintaining ATT knowledge and familiarity $\ldots \ldots \ldots \ldots 68$

25. List of organizations visited or otherwise researched and related media information . . . 73

26. Summary of distance learning and multimedia use for organizations surveyed $\ldots \ldots \ldots 86$

27. Summary of distance learning and multimedia types used $\ldots \ldots \ldots \ldots \ldots \ldots \ldots$

28. Continuum of organizational aspects observed $\ldots \ldots \ldots \ldots \ldots \ldots \ldots \ldots \ldots$

29. Five proposed levels of general acceptance and readiness for technology

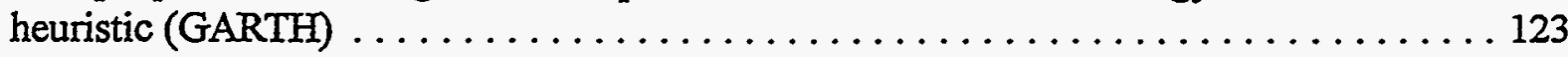

30. Characteristics of each level in general acceptance and readiness for

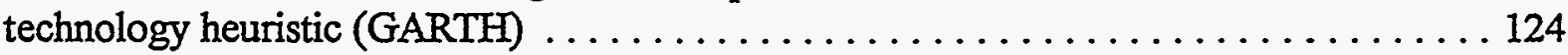

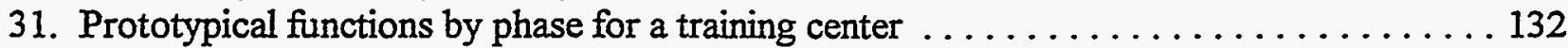

32. Estimated levels and important features to note from surveyed organizations $\ldots \ldots \ldots 142$ 


\section{INTRODUCTION}

This technical report summarizes the work performed by the Idaho National Engineering Laboratory under contract to the Department of Energy (DOE) Office of Training and Human Resource Development (HR-2). The purpose of the report is to provide the customer and others with up-to-date information concerning the nature and potential of advanced training technology (ATT) and to provide insights into its application. This report provides a brief description of many of the significant advanced technologies, associated training centers and ATT efforts available for study at the time that this report was published.

The study discusses five major topics relating to ATT. Each topic consists of a set of closely related questions regarding some aspect of ATT and the answers to those questions that emerged through research. The topics covered are: 1) currently available ATT; 2) actual use of ATT and lessons learned in organizations similar to DOE; 3) methods for selecting media and for evaluating cost-benefit as related to ATT; 4) DOE's current need for, readiness for, and usage of ATT; and 5) recommended next steps for DOE. The fourth topic, DOE's current status, is included because of its relevance to developing answers to the question in the final topic. However, because the focus of the study was on the first three topics, the answers to questions in the fourth topic are preliminary and incomplete. It is useful to know what questions still need to be answered. Additional needs assessment, design, and investigative work will provide adequate answers to the important questions raised in the fourth topic.

This work presumes that technology is a means, not an end, and that ATT is only valuable as it increases the amount and quality of learning that takes place. This fundamental assumption is well stated by the Chief Executive Officer of IBM, one of American's most prestigious technology companies:

Technology is a tool, not an end objective. It lets you do something-once you've set out what you want to accomplish. Information technology makes it possible for people to become true knowledge workers, to increase their output and change the nature of their job, and that's exactly what we want to do with students. We want to increase outputs and change [the] nature of their job! Their job is not to be worked on, but to be the worker. 


\section{The Topics Addressed in this Study}

The Department of Energy (DOE) is interested in finding the most cost-effective ways of providing education and training to its employees and contractors. This study summarizes the emerging answers found by investigating advanced training technologies (ATT) for DOE and surveying their use around the country, and extrapolates lessons learned to aid planners and decisionmakers in charting the course for DOE education and training. The five topics and their related questions listed below form the primary structure of this report. 


\section{Topic 1. Availability and Considerations of ATT}

Questions:

1.1 Why is it important to consider ATT at this time? What general considerations apply broadly to DOE and other organizations seeking to discover the potential of $A T T$ ?

1.2 What are the advanced training technologies? What are the strengths and limitations of each of these advanced technologies?

1.3 What taxonomies are available to help differentiate the many types of multimedia-related technologies?

1.4 What logistic implications do these technologies have? What kinds of organizational or training facility configurations may be required?

1.5 What are the best resources to help novices become familiar with these technologies and stay current with trends and progress?

1.6 What technologies are just emerging (becoming widely available) and how might these impact near term and long-term planning?

Approach: To answer this first set of questions, much of the literature available on advanced technologies was reviewed; several national conferences on multimedia, distance learning, and related topics were attended; and experts, numerous facilities and organizations were visited. Because of funding limitations and the desire to focus on first steps, this phase of the project did not attempt to answer the last question about emerging technologies. This last question will be addressed following the current effort.

Results: Four important advanced technologies are described and the considerations of their strengths and limitations are presented. A taxonomy of four types of multimedia is presented. Logistic and organizational options are presented. Suggestions and bibliographic references are also provided for helping novices become current with advanced technologies and for helping others stay current. Finally, a brief list of emerging technologies is presented. 


\section{Topic 2. Actual ATT Use and Lessons Learned}

Questions:

2.1 How widespread is the use of advanced technologies at similar government agencies, within the military, in industry, and in academia?

2.2 What types of distance learning and multimedia technologies are being used?

2.3 How are representative institutions incorporating ATT into their organizations and into their existing or planned physical facilities?

2.4 What are some of the most exceptional practices and most notable successes in utilizing $A T T$ ?

2.5 What lessons can be learned from other organizations' experiences with $A T T$ and with centralized training facilities?

Approach: To answer this second set of questions, case studies of advanced technology use were reviewed, numerous telephone interviews were conducted, information was gathered from several conference presentations related to specific organizations' experience in applying ATT, and more than two dozen facilities or institutions were visited.

Results: The results of a broad based and rapidly conducted survey are presented. The institutions visited or otherwise investigated are listed in Table 25 (note that Appendix B is an extension of Table 25). Some notable successes are highlighted. This table briefly describes how ATT is being used at these institutions. Then the lessons that wrere learned from the survey are presented. 


\section{Topic 3. Approaches for Selecting, Evaluating Cost-Benefit, and Strategically Planning for ATT Use}

\section{Questions:}

3.1 What are some of the fundamental systems and performance improvement principles that provide the backdrop against which all media and method selection decisions are made?

3.2 What would be a good process for DOE to use in evaluating potential effectiveness of advanced technologies for use DOE-wide, at specific sites, or for specific courses or curriculum?

3.3 What kind of cost-benefit analysis process should DOE use to evaluate alternate approaches for delivering education and training?

3.4 What strategic tools or models are available that could help DOE develop progressive, yet realistic, strategic plans for using advanced technology?

3.5 Given the data collected, lessons learned, methods, processes, and models studied, what guidelines can be offered for creating a centralized training function? What phases might serve as a strategic plan for a centralized training function or center?

3.6 How do these guides, processes, and models relate to Performance-Based Training (PBT) and the Systematic Approach to Training (SAT)?

Approach: To answer this third set of questions, several media selection guides, costbenefit analysis methods, training center plans and strategic models were reviewed.

Results: A general discussion of media-method selection models, cost-benefit analysis approaches, and strategic tools and models is presented. A generic plan for centralizing training is presented. (Note that one particularly useful media selection model is included in Appendix A of this report.) Finally, the relevance of these models to the overall PBT and SAT processes is discussed. 


\section{Topic 4. Current Status and Needs of DOE Relative to ATT}

\section{Questions:}

4.1 Where is DOE as a whole with regard to its readiness to adopt and effectively implement $A T T$ ?

4.2 How does DOE compare to other similar organizations in its ability to appropriately use $A T T$ and what specific lesson(s) can be learned from each organization studied?

4.3 What needs and problems does DOE have that ATT can help meet and resolve, thus creating significant improvements in competence and effectiveness while reducing costs?

4.4 What specific capabilities are currently available to DOE (at various levels) to support the use of ATT?

4.5 What additional infrastructure should be put in place to facilitate future use of $A T T$ ?

4.6 What organizational changes (management, structures, culture, etc.) are needed to facilitate future use of ATT?'

4.7 What cost data is currently available within DOE to use in cost-benefit analyses?

Approach: While these questions are no less important than the previous sets (in fact, probably more so), their answers are much harder to obtain. Complete answers would require data gathering and analysis far beyond the constraints of this study (i.e., a complete departmental needs analysis).

Results: The estimated current position of DOE relative to its readiness to use advanced training technologies and relative to other organizations surveyed is presented. An extensive table is included that lists specific lessons that can be learned from the other organizations studied. These organizations have been ranked according to their maturity or readiness to implement ATT. The lack of thorough needs analysis and cost data, and the importance of gathering and analyzing this information prior to making further plans for widespread use of ATT is noted. Many of the questions are listed but not answered as extensive additional research and analysis would be required by the DOE. 


\title{
Topic 5. Final Recommendations
}

\section{Question:}

5.1 Given what has been learned (i.e., types and considerations about ATT, lessons from the surveyed organizations using ATT, example processes for selecting and evaluating the cost-effectiveness and readiness for ATT, and DOE's present status), what are some specific tactical and strategic next steps that should be taken by DOE?

\begin{abstract}
Approach: The following were all used to derive a short list of specific recommendations for the next steps: generic information about ATT; lessons learned from the surveyed organizations; various models and approaches for media selection, cost-benefit analysis, and technology readiness and acceptance; and data and estimates of DOE's current status and needs.
\end{abstract}

Results: The final part of this study presents the resulting recommended list of specific next steps.

\section{Background and Limitations}

This work is based on an intense but rapid survey of many existing training technologies and training institutions. Although the lessons learned provide general guidelines for incorporating technology in training programs, they cannot be interpreted as a specific guide for media selection since the particular needs of an organization are organizationally-based and must be addressed individually. However, an understanding of the advanced training technologies should be a valuable contribution to a systematic approach to solving an organization's performance, training, and educational problems.

Surveys of topic areas can be done at various levels. This study has been conducted at a fairly high level, not only to conserve time and money, but also because broad patterns are more easily discernible from this perspective. This survey and the level of detail being summarized is analogous to an aerial surveillance effort where several flights are taken quickly over the terrain with the intent of looking at the big picture-capturing general patterns and broad impressions-rather than creating a comprehensive topographical map.

As part of this study, many journals and trade publications were reviewed; several trade sponsored conferences were attended - Orlando Multimedia 1994, sponsored by the Society for Applied Learning Technology (SALT), Interservice/Industry Training Systems and Education Conference (I/ITSEC), sponsored by the National Security Industrial Association (NSIA), International Distance Learning Conference (IDLCON) sponsored by the United States Distance Learning Association (USDLA), Training Resource and Data Exchange (TRADE) Conference, sponsored by Oak Ridge Institute for Science and Education, and the InfoTech DOE Technical 
Information Meeting, sponsored by the U.S. Department of Energy Office of Scientific and Technical Information; over a score of government, private industry, and educational institutions were visited; dozens of training professionals were interviewed; and excellent resources that were recently produced by the Department of Defense and other Federal Agencies were collected and used.

Originally this task was viewed as a benchmarking activity. However, "exploration and discovery" better describe the effort than benchmarking. Note that with only one or two exceptions, all the academic, industry, government and military contacts made (once the right individuals were found), were most willing to share their time, set up tours or personally escort the researchers on visits around their facilities, and provide extensive printed materials. Even those organizations with fairly traditional methods and media were willing and proud to share with us their successes, difficulties, and lessons learned. Across the board, it is estimated that the study encountered instances of approximately half of the typical and best practices in the use of currently available ATT.

Note that with the rapid changes taking place in technologies and their application to education and training, it is expected that there would be some major changes in the overall sketch presented here within three to five years. 


\section{TOPIC 1. AVAILABIITY AND CONSIDERATIONS OF ATT}

The first part of this study covering Topic 1 presents information about ATT that is currently available and of interest to DOE. An introductory section presents generalities about ATT and its overall applicability to DOE. Then the major types of ATT, both hardware and integrated hardware/software solutions, are described, examples given, and the major strengths and limitations of each are presented. A taxonomy is then presented for four types or classifications of multimedia. This taxonomy is useful in helping to differentiate between low-cost, simple applications and complex, expensive ones. With the various ATT described, organizational and logistic implications regarding their use are presented. Suggestions and references are also provided for helping novices become current with advanced training technologies and for helping those responsible for tracking developments to stay current. As the focus of this study was on existing and available advanced technology, few resources were devoted to perform a future search. A skeletal list of emerging technologies, however, was quickly compiled and completes the topic.

Note that the data included is current as of late 1994 and is subject to obsolescence. Also of note is that exclusion of older, more familiar technologies is not a statement regarding their usefulness or effectiveness. Many of the tried and true training technologies that pre-dated computers, networks, satellites and teleconferencing have become (and will probably remain) key methods for delivering many kinds of instruction for a wide range of purposes for many more years. These are not presented or discussed because it is assumed that their strengths and limitations are familiar to most readers and because the intent of this study is to help acquaint readers within $\mathrm{DOE}$ with the potential of the newer, more advanced training technologies.

\section{Subtopic 1.1 Overview of the Relevance of ATT to DOE}

\section{Why is it important to consider ATT at this time? What general considerations apply broadly to DOE and other organizations seeking to discover the potential of ATT?}

Technology is an integrated and accepted part of American society. The advanced technologies of most immediate benefit to education and training activities are communications (program broadcast via cable, radio, television or satellite; audio, video and computer teleconferencing; and various kinds of interactive information access via communication links) and numerous computer-based technologies (computer-based instruction, multimedia, computer networking, and electronic performance support systems). While these two technologies have been merging for several years, many experts believe that soon they will become so intertwined that they will be considered one single, integrated technology.

Advances in communication technology are providing faster and more efficient information sharing and delivery of training and education across distances. These activities are frequently referred to as teleconferencing or as computer networking. Computer technologies (both hardware and software) are becoming available to work with the various communications 
technologies in finding, filtering, and organizing the information. Given the ever-increasing volume of information becoming available through multiple communications, it is becoming more and more important for managers, instructors, workers and learners to acquire the ability to use these new computer-based technologies to access, analyze, filter, and organize the information that is relevant to them. In many instances just being able to get the right information at the right time precludes various kinds of "just-in-case" training. In other situations, the information being sought and interacted with may be formal educational or training resources.

Extensive attention is being given to the merging of communications and computer technologies. This merger may eventually supersede many of the advanced training technologies described in this study, particularly those that include stand-alone information disks or courseware material. However, many of these stand-alone systems (i.e., Interactive Video Disc [IVD] and Compact Disc-Read Only Memory [CD-ROM]) are currently the most cost-effective, most advanced, and most widely available; therefore, the basics about them are presented here. Even when these technologies are eventually replaced, many of their strengths and limitations will be carried forward to their replacement systems.

Before networking of computers was as prevalent as it is today (and as it is continuing to become), these stand-alone systems (i.e., IVD and CD-ROM) defined the essence of advanced training technology, and "multimedia" was commonly used to describe them because they integrated two or more media with a personal computer. The media list includes audio, video, text, graphics, and animation. The dynamic growth of many technologies (including the integration technologies that bring the diverse systems under the control of a personal computer) offers extremely powerful tools in many fields, especially education and training. Because of this growth, the term "multimedia" has expanded to mean a user-controlled system that coordinates and integrates computing and communications technologies. Given this new, broader definition, it is possible to include just about all of the advanced training technologies under this umbrella term.

Current trends in communications, education and training technologies can be discerned and insight in these areas can help providers position their operations for future capabilities. Some of the trends in communications technologies, as seen by one noted multimedia author and expert (Jeff Burger, 1993) are:

- Computers and television technologies will combine, blurring any meaningful distinction.

- Teleconferencing, networking, even virtual environment technologies will merge into the multi-faceted communications giant. Witness the current rush by these industries to team with partners in related companies.

- Sophisticated communications technology will concentrate on providing just-in-time, embedded training or refresher tutorials to workers beginning difficult tasks.

- All desktop and portable computers, in business and home, will be multimedia-capable. 
- Emphasis will continue toward automating development and production processes, making it easier for new users to use more of the power in the technologies.

Other than being new, what are the potential benefits of multimedia and why should DOE be interested in possibly pursuing multimedia applications? The following initial observations about the potential of multimedia and communications for education and training are supported by current literature and reinforced by this study.

Table 1. Potential benefits from technology for training.

\begin{tabular}{|l|l|}
\hline Multisensory delivery & $\begin{array}{l}\text { Research in learning styles shows that some learners learn } \\
\text { best from audio, some from visual, some from touch. } \\
\text { Multimedia instruction tends to assist more learners. }\end{array}$ \\
\hline $\begin{array}{l}\text { Self-expression and active } \\
\text { learning }\end{array}$ & $\begin{array}{l}\text { Technologies provide stimulating environments for learners } \\
\text { to be active in the learning process. Active involvement on } \\
\text { the part of learners results in many positive effects. Meta- } \\
\text { analyses have indicated that on the average, performance } \\
\text { improves by one-half standard deviation while learning time } \\
\text { decreases by 30\% or more. }\end{array}$ \\
\hline Cooperative learning & $\begin{array}{l}\text { Technology provides more opportunities for learners to } \\
\text { work cooperatively. Some multimedia programs can serve as } \\
\text { manager, organizational base, advisor, and evaluator of the } \\
\text { group activities. Teachers have implemented cooperative } \\
\text { learning with technology-supported activities and report an } \\
\text { increase in instructional effectiveness and efficiency and } \\
\text { positive social interactions. }\end{array}$ \\
\hline Motivation & $\begin{array}{l}\text { The use of computer networks to go beyond the classroom } \\
\text { can provide unique opportunities for learners to practice, } \\
\text { demonstrate, and critique communication skills. } \\
\text { Computer-based telecommunications can particularly benefit } \\
\text { instruction in problem-solving, decisionmaking, and other } \\
\text { critical thinking skills. }\end{array}$ \\
\hline $\begin{array}{l}\text { Technology promotes interest and motivation for learners } \\
\text { and teachers by making learning exciting and relevant. } \\
\text { Research shows that learners react positively to the } \\
\text { integration of technology and therefore stay on task for } \\
\text { longer periods. }\end{array}$ \\
\hline
\end{tabular}


All of the needs listed above are relevant to some extent to DOE and all organizations that have training and education requirements. Multimedia appears to have great potential in helping DOE and other organizations address some of these needs. Extensive studies into the costeffectiveness of various types of multimedia have typically shown significant improvement in learning effectiveness, retention, and efficiency. These effectiveness benefits can be measured against costs (which also tend to be significant) along with organizational readiness issues as will be discussed in the answers addressed under Topic 3 of this study.

Experience has shown that the adoption of ATT is not without its problems. The literature and the results of this study point out a number of important restraints limiting technology infusion into education and training including:

- "Mistrust of the unknown" that many experienced and respected educators, trainers, and managers have for advanced technology.

- Difficulty of comprehending the constantly changing, detail-demanding, and often oversold capabilities of the technologies offered as "tools."

- A frequently shared opinion that use of technology in the training setting is a surrender to the entertainment media.

- Lack of sufficient training for teachers, trainers, course designers, and managers in the effective use of technology-based tools.

- Incomplete research of specific cost-effectiveness associated with the use of various ATT.

- High front-end costs associated with computers and other communication systems.

- Expectations on the part of many learners for high-energy, commercial quality, instantaneous, and tailored delivery of most information (i.e., the MTV generation).

Are the benefits greater than the restraints listed above? Why should DOE be anxious to explore the application of ATT - to become part of this new generation? If the new technologies offered nothing more than greater potential efficiency, they would be worth looking into, but many have the possibility to greatly improve effectiveness in helping individuals acquire and maintain vital skills required now and in the future.

For an organization to adopt these technologies, a critical mass of educators and trainers and their managers (along with learners) must become comfortable and even masters of ATT-related skills. How to attain this familiarity and skill is addressed in Subtopic 1.5. Most successful managers and training staff who are responsible for performance improvement have established contacts with experts to help keep them abreast of technology research, design and implementation and especially cost-effectiveness issues. Even the most progressive research 
institutions rely heavily on experts to provide them with the latest information and lessons learned. Most educators and trainers cannot be expected to be expert in the intricacies of all computer and communications technology, any more than a computer scientist can be expected to be expert in the research, design, development and delivery of instruction. Because of the stakes involved, expert help can quickly pay for itself by preventing costly errors in the selection and application of computer or technology-based systems.

Finally, educators and trainers within DOE, in looking at the potential of ATT, must always keep in mind that for all the enhancements possible through the infusion of appropriate technologies into instruction, technology remains only a tool to aid job performance and learning. Technology is not education. Technology is not training. Lest the learning curve and limitations of these technologies discourage or overwhelm to the point of complete avoidance, it is just as important for DOE educators and trainers to remember that those who fail to attempt to stay current and employ the best tools available will eventually slip into mediocrity and become about as useful and respected as a factory that makes buggy whips. These advanced training technologies have great promise, are beginning to revolutionize many aspects of education and training, and should be seriously studied and evaluated. ${ }^{1}$

\section{Subtopic 1.2 ATT Descriptions and Strengths and Limitations}

\section{What are the advanced training technologies? What are the strengths and limitations of each of these advanced technologies?}

This subtopic provides a concise summary of the important characteristics, trends, and terminology associated with many types of advanced training technology. This section should be particularly helpful for newcomers to the field of training as it contains a quick review of several technologies such as Interactive Video Disc, CD-ROM, computer-assisted training and computerbased training, and distance learning technologies such as audio, video, and computer teleconferencing. Some of these advanced training technologies are listed in Subtopic 1.6. Note that advanced training technologies that are just now emerging (but relatively unproven) have not been included in this subtopic.

Table 2 below presents the four basic kinds of technologies being presented in this subtopic: multimedia, teleconferencing, computer networking, and courseware applications. The table lists the type of technology, the basic computer hardware and additional computer electronics required, communications equipment required, and instructional design/management resources needed. The first three are distinguished by the hardware involved, while the last is based on software and courseware applications. The definitions of these technologies are provided in separate sections that follow the table.

\footnotetext{
1 Such revolutionary changes, for specific education and training needs, are now starting to occur with the use of advanced training technologies. For example, some kinds of trouble-shooting training that previously took weeks, if not months, is being accomplished effectively in days or hours through the use of ATT.
} 
Table 2. Overview of the various advanced training technologies covered in this study.

\begin{tabular}{|c|c|c|c|c|c|}
\hline Marinced Irinimg & 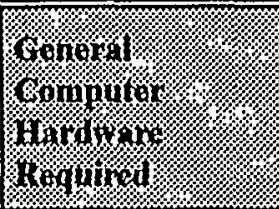 & 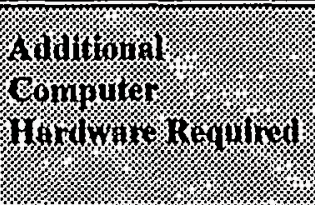 & 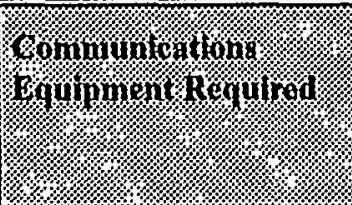 & 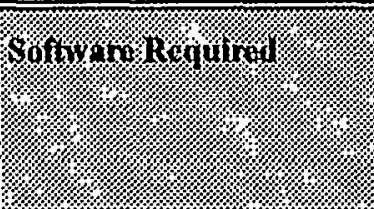 & 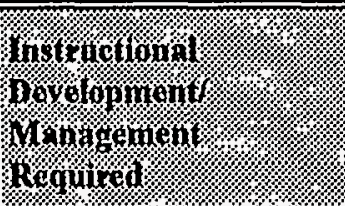 \\
\hline mimirimedrin & $\begin{array}{l}\text { Personal } \\
\text { Computer } \\
\text { (typically IBM- } \\
\text { compatible or } \\
\text { Macintosh) }\end{array}$ & $\begin{array}{l}\text { CD-ROM player and } \\
\text { interface card. Audio } \\
\text { card and speakers. }\end{array}$ & None & $\begin{array}{l}\text { CD-ROM and audio } \\
\text { drivers }\end{array}$ & $\begin{array}{l}\text { Depends on application. } \\
\text { (See subtopic } 1.3 \text { for } \\
\text { types of multimedia.) }\end{array}$ \\
\hline 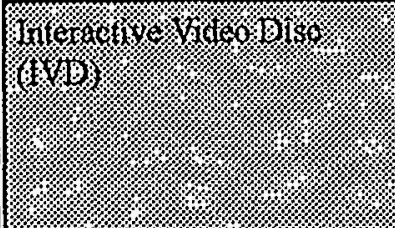 & $\begin{array}{l}\text { Personal } \\
\text { Computer }\end{array}$ & $\begin{array}{l}\text { IVD player, special } \\
\text { interface card. Audio } \\
\text { card and speakers. }\end{array}$ & None & IVD drivers & $\begin{array}{l}\text { Four levels previously } \\
\text { defined. Highest levels } \\
\text { require extensive } \\
\text { courseware } \\
\text { development. }\end{array}$ \\
\hline 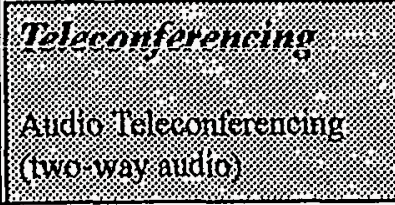 & None & None & $\begin{array}{l}\text { Individual microphones } \\
\text { and switches or speaker } \\
\text { phone system. Phone } \\
\text { lines. }\end{array}$ & None & $\begin{array}{l}\text { Printed materials sent in } \\
\text { advance for reference } \\
\text { during verbal } \\
\text { discussion. }\end{array}$ \\
\hline 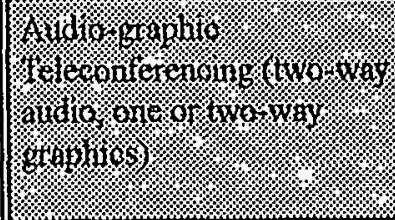 & $\begin{array}{l}\text { (Newer graphics } \\
\text { may be used, } \\
\text { personal } \\
\text { computers linked). }\end{array}$ & None & $\begin{array}{l}\text { Audio equipment as } \\
\text { above, also graphics } \\
\text { input and display } \\
\text { devices. Phone lines. }\end{array}$ & $\begin{array}{l}\text { (If computer is used for } \\
\text { graphics, special software } \\
\text { is required). }\end{array}$ & $\begin{array}{l}\text { Print materials for non- } \\
\text { dynamic images. } \\
\text { Dynamic images can be } \\
\text { sent via graphic } \\
\text { channel. }\end{array}$ \\
\hline
\end{tabular}


Table 2. Overview of the various advanced training technologies covered in this study.

\begin{tabular}{|c|c|c|c|c|c|}
\hline tedinology & 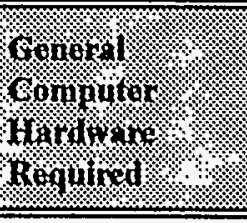 & 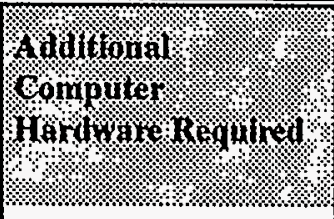 & 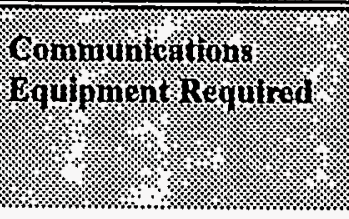 & S & Movolopingut: \\
\hline $\begin{array}{l}\text { Video Teleconferencing } \\
\text { (telephone-based) }\end{array}$ & None & None & $\begin{array}{l}\text { Special purpose video } \\
\text { and audio equipment } \\
\text { including camera(s), } \\
\text { controls, compression } \\
\text { unit, displays, and } \\
\text { speakers. Phone lines. }\end{array}$ & None & $\begin{array}{l}\text { Preplanning of course. } \\
\text { Instructor training. Can } \\
\text { still benefit by access to } \\
\text { pre-printed materials. }\end{array}$ \\
\hline 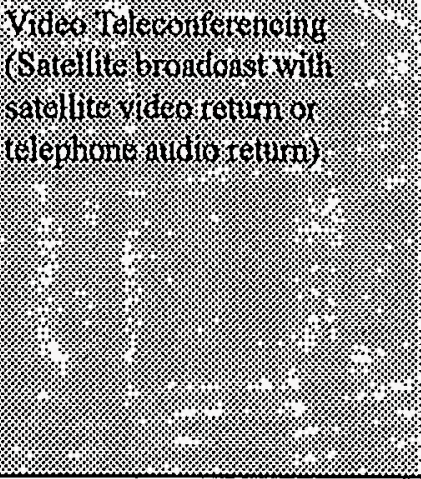 & None & None & $\begin{array}{l}\text { Special camera and } \\
\text { uplink capability at } \\
\text { source. Satellite } \\
\text { downlink at receiving } \\
\text { ends. May be digital or } \\
\text { analog. Display } \\
\text { monitors. Audio } \\
\text { conferencing type } \\
\text { equipment for one-way } \\
\text { video and one-way } \\
\text { audio. }\end{array}$ & None & Handouts \\
\hline ?4: & $\begin{array}{l}\text { High-end PC or } \\
\text { workstation }\end{array}$ & $\begin{array}{l}\text { Special video board } \\
\text { which compresses } \\
\text { and decompresses. } \\
\text { Speakers. }\end{array}$ & $\begin{array}{l}\text { Miniature display- } \\
\text { mounted cameras. } \\
\text { Phone lines or other } \\
\text { network connection. }\end{array}$ & $\begin{array}{l}\text { Special software to create } \\
\text { windows for each party } \\
\text { being linked to, as well as } \\
\text { common image or } \\
\text { document editing screens. }\end{array}$ & $\begin{array}{l}\text { Depends on course } \\
\text { being taught. }\end{array}$ \\
\hline
\end{tabular}


Table 2. Overview of the various advanced training technologies covered in this study.

\begin{tabular}{|c|c|c|c|c|c|}
\hline 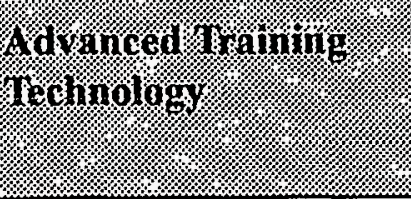 & 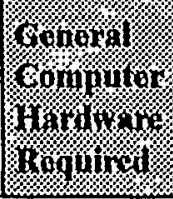 & 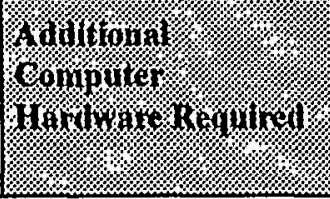 & 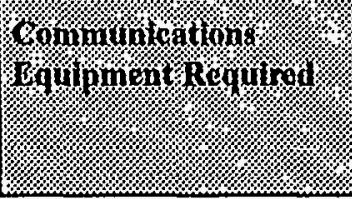 & Sift? & movorivnint: \\
\hline 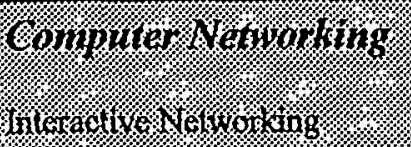 & PC & $\begin{array}{l}\text { Network card or high } \\
\text { speed modem. }\end{array}$ & $\begin{array}{l}\text { Modem and phone line } \\
\text { or some kind of physical } \\
\text { network connection. }\end{array}$ & Communications software & $\begin{array}{l}\text { Depends on course } \\
\text { being taught. }\end{array}$ \\
\hline 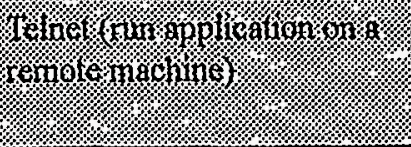 & $\mathrm{PC}$ & $\begin{array}{l}\text { Network card or high } \\
\text { speed modem. }\end{array}$ & $\begin{array}{l}\text { Modem and phone line } \\
\text { or some kind of physical } \\
\text { network connection. }\end{array}$ & Telnet software & $\begin{array}{l}\text { Depends on course } \\
\text { being taught. }\end{array}$ \\
\hline 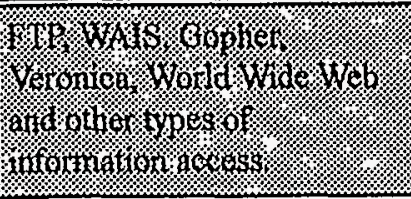 & $\mathrm{PC}$ & $\begin{array}{l}\text { Network card or high } \\
\text { speed modem. }\end{array}$ & $\begin{array}{l}\text { Modem and phone line } \\
\text { or some kind of physical } \\
\text { network connection. }\end{array}$ & Internet utility software & $\begin{array}{l}\text { Depends on course } \\
\text { being taught. }\end{array}$ \\
\hline 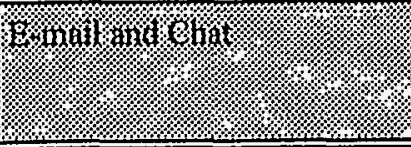 & $\mathrm{PC}$ & $\begin{array}{l}\text { Network card or high } \\
\text { speed modem. }\end{array}$ & $\begin{array}{l}\text { Modem and phone line } \\
\text { or some kind of physical } \\
\text { network connection. }\end{array}$ & $\sqrt{\text { E-mail and Chat sofiware }}$ & $\begin{array}{l}\text { Depends on course } \\
\text { being taught. }\end{array}$ \\
\hline 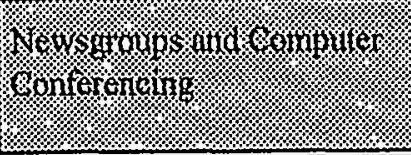 & $\mathrm{PC}$ & $\begin{array}{l}\text { Network card or high } \\
\text { speed modem. }\end{array}$ & $\begin{array}{l}\text { Modem and phone line } \\
\text { or some kind of physical } \\
\text { network connection. }\end{array}$ & $\begin{array}{l}\text { Newsgroup reader or } \\
\text { special computer } \\
\text { conferencing software. }\end{array}$ & $\begin{array}{l}\text { Depends on course } \\
\text { being taught. }\end{array}$ \\
\hline
\end{tabular}


Table 2. Overview of the various advanced training technologies covered in this study.

\begin{tabular}{|c|c|c|c|c|c|}
\hline 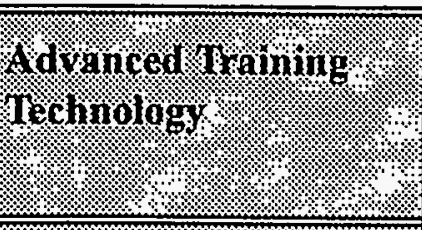 & 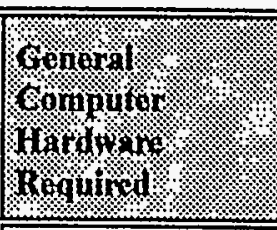 & Q. & 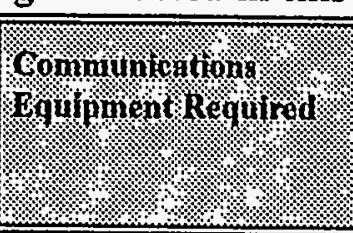 & 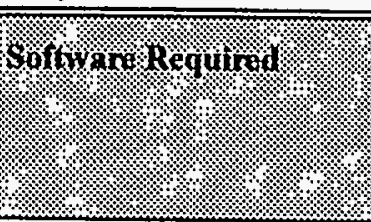 & 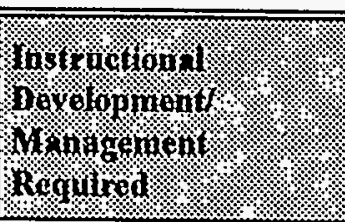 \\
\hline 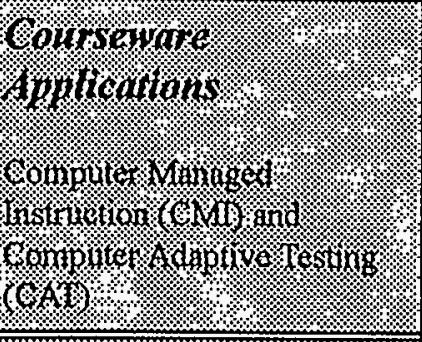 & $\begin{array}{l}\text { PC, workstation } \\
\text { up to mainframe. }\end{array}$ & $\begin{array}{l}\text { (May be networked or } \\
\text { stand-alone). }\end{array}$ & $\begin{array}{l}\text { (If networked, will } \\
\text { require network } \\
\text { connection). }\end{array}$ & $\begin{array}{l}\text { Software to manage } \\
\text { progress through course } \\
\text { and/or conduct adaptive } \\
\text { testing. }\end{array}$ & Extensive \\
\hline (4) & PC & $\begin{array}{l}\text { (May be networked or } \\
\text { stand-alone). }\end{array}$ & $\begin{array}{l}\text { (If networked, will } \\
\text { require network } \\
\text { connection.) }\end{array}$ & $\begin{array}{l}\text { Simple to complex } \\
\text { courseware to allow } \\
\text { information search or } \\
\text { teach concepts or } \\
\text { procedures. }\end{array}$ & $\begin{array}{l}\text { Depends on complexity } \\
\text { of the courseware. }\end{array}$ \\
\hline 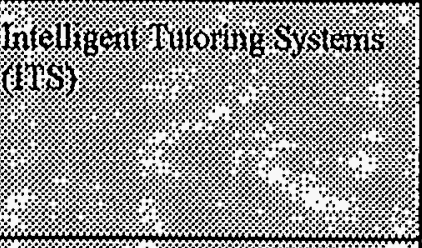 & PC or workstation & $\begin{array}{l}\text { (May be networked or } \\
\text { stand-alone.) }\end{array}$ & $\begin{array}{l}\text { (If networked, will } \\
\text { require network } \\
\text { connection.) }\end{array}$ & $\begin{array}{l}\text { Very sophisticated } \\
\text { software to tutor the } \\
\text { learner in some content } \\
\text { area or to perform some } \\
\text { task. }\end{array}$ & Extensive \\
\hline 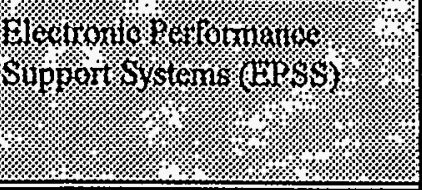 & $\begin{array}{l}\text { PC, laptop, } \\
\text { notebook, or } \\
\text { personal digital } \\
\text { assistant. }\end{array}$ & $\begin{array}{l}\text { (May be networked or } \\
\text { stand-alone.) }\end{array}$ & $\begin{array}{l}\text { (If networked, will } \\
\text { require network } \\
\text { connection.) }\end{array}$ & $\begin{array}{l}\text { Sophisticated integration } \\
\text { of tools and CBT or ITS. }\end{array}$ & Extensive \\
\hline
\end{tabular}




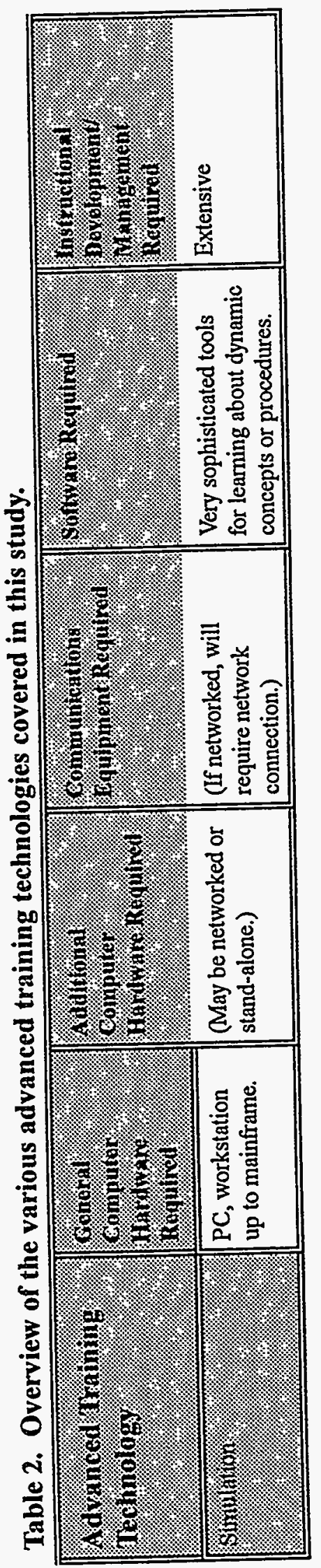

$\infty$ 


\section{Multimedia}

\section{Compact Disc-Read Only Memory (CD-ROM)}

Overview-Technologies maturing in the 1970s led to audio CDs that gained consumer popularity in the 1980s. They were used only for audio playback (i.e., for music and book texts recorded for the visually impaired or for commuters driving in their autos). The Compact Disc-Read Only Memory (CD-ROM) technology is a natural extension of the audio CD, but instead of just digitized audio, the CD-ROM can store computer-readable programs, text data, images, and digital audio files. The information on the CD-ROM is permanent and cannot be modified or erased.

Application to Education and Training-A CD-ROM disc can store information in a variety of formats, many of which offer valuable educational and training assistance. The combination of large storage capacity, plus search capability, makes CD-ROM useful in many applications, including:

- Reference sources

- Databases

- Multimedia educational and entertainment products

- Computer software.

CD-ROMs store computer information and are an ideal medium for distributing computer programs. One CD-ROM can replace approximately 460 High Density Double-sided computer diskettes. Distribution via CD-ROM is advantageous not only because of the light weight and small volume, but also because it is read-only, and thus a mistake will not erase a CD-ROM. The capacity of one CD-ROM disc exceeds 650 megabytes, which is equivalent to the entire text of a 20-volume encyclopedia or two and a half years of USA Today. In the Navy and the Air Force, the entire contents of the technical orders for a major weapon system can be stored on one or two CD-ROM discs, while printed versions were measured by the room full.

One of the most useful applications is for reference sources. The large capacity allows the storage of text, charts, graphics, pictures, video and sound on a single disc. It is now becoming common for entire conference proceedings to be stored and distributed on CD-ROM. The power of electronic conference proceedings lies not only in the rapid access to a particular article, such as those related to alternate sources of energy or waste cleanup, but in the ability to use terms like "energy" or "hazardous" waste as keywords to find every occurrence of a particular topic in the proceedings. 
Examples-Educators, trainers, courseware developers, and researchers can use the power of CD-ROM reference disks to access reference materials and to publish or make available inexpensively to every student all relevant manuals, handbooks, policy statements, and technical orders for a given subject area. The following commercial examples may also be of value.

- Information Finder by World Book does not currently provide sound or graphics; however, it does offer competitive pricing, powerful search techniques, and a fast and efficient interface. Furthermore, the World Book Dictionary, with over 140,000 definitions, is available from within the encyclopedia.

- Microsoft BookShelf by Microsoft loads into the memory of the computer and stays in the background while another computer program, such as a word processor, is running. Microsoft BookShelf reference materials can be called up at any time (without closing the word processor). They include the American Heritage Dictionary, World Almanac, U.S. Zip Code Directory, Roget's Thesaurus, Bartlett's Familiar Quotations, and The Chicago Manual of Style.

- Several encyclopedias are available, all of which provide a fast, efficient alternative to manually searching an encyclopedia. For example, Microsoft's Encarta, Compton's Multimedia Encyclopedia, and Grolier's Multimedia Encyclopedia are now available for both Macintosh and IBM-compatible computers and include sound, pictures, and powerful search techniques.

- The Webster's Ninth New Collegiate Dictionary by Highlighted Data contains all the features of its print edition (over 200,000 definitions) plus entry words pronounced by a human voice, an option to change the display size to large type for easy reading, and the ability to jump from one place to another to check cross-referenced words.

- The Education Resources Information Center (ERTC) is a national bibliographic database for literature related to education. ERIC references over 775 professional journals and 300,000 documents from other sources, such as conference papers and research studies. Several companies supply search software for ERIC and distribute the database on CD-ROM.

- Periodical Abstracts, by University Microfilms International, provides citations and abstracts of articles in over 300 general and reference periodicals in the areas of arts, business, science and computers, health, news, lifestyles, commentary, education, literary and political reviews, consumer, and social issues.

- SIRS (Social Issues Resources Series) provides timely information from newspapers, magazines, government publications, and journals. Permission can be obtained from SIRS for reprints, so full text can be downloaded to disk or printed. Abstracts are provided for any articles that are not available for replication. 
One of the most important applications for CD-ROM technology is the storage of large databases. Prior to CD-ROM, databases were usually stored in huge indexes in libraries or mainframe computers. Computers and modems accessed the mainframe computers, but it was expensive and many potential users did not have the necessary equipment or telephone lines.

Many of the indexes available on CD-ROM, instead of containing the full text of the articles, provide the author, title, journal, year of publication, and an abstract. The user can read the abstract or save the information to a diskette. For example, potential DOE users of CD-ROM databases include not only education and training developers, but the learners themselves. Making masses of technical information conveniently available serves everyone from field office decisionmakers and headquarters staff to site technicians, planners, and managers.

CD-ROMs can store as digital data the information presented as text, graphics, sound, video, and animation. With these capabilities, CD-ROM has become a major medium for multimedia products. Integrated with a computer system, CD-ROM's storage capacity enables interactivity in training programs in a wide variety of subjects. The Air Force, for example, has added the power of CD-ROM to some of its performance improvement programs that bridge with on-line training. One project for the San Antonio Air Logistics Center uses two CD-ROMs linked to the computer to provide Federal Stock Numbers and military parts numbers for the thousands of electronic cables and connectors used in aircraft systems. The identification and training system is computer-based and on the computer's hard disk. The computer system accesses the CD-ROMs to find and import appropriate data. The Navy has used a similar "jukebox" system of 3 to 7 CD-ROMs for several years.

Many commercial companies "publish" CD-ROM products for consumer, education and training applications. In addition to adding sound and visuals to previously print-only information sources (e.g., encyclopedias), the multimedia products are credited with getting and sustaining learners' interest in learning.

To read and display the information on a CD-ROM disc, a $C D$ ROM player must be connected to a computer. The computer can read the data on the CD-ROM disc as if it were a hard drive. In other words, you can receive a directory listing or even copy files from the CD-ROM disc to a diskette or hard drive. To provide efficient access to the information on the disc, most CD-ROM applications provide software programs to search and retrieve the desired information. This software may be located on the CD-ROM disc or it may be provided on diskette.

Strengths and Limitations-Although CD-ROM technology offers many educational and training benefits, it is not appropriate for every program. The following table (Table 3 ) describes CD-ROM's various strengths and Table 4 describes CD-ROM's limitations. 
Table 3. Strengths of CD-ROM.

\begin{tabular}{|l|l||}
\hline Storage capacity & $\begin{array}{l}\text { Each disc can store over } 650 \text { megabytes of data, graphics or } \\
\text { sound. That capacity is equivalent to hundreds of floppy } \\
\text { disks. }\end{array}$ \\
\hline Portability & $\begin{array}{l}\text { Discs are small and lightweight, an ideal medium for } \\
\text { transporting data. }\end{array}$ \\
\hline Durability & $\begin{array}{l}\text { Discs are very durable. Fingerprints and slight scratches will } \\
\text { not usually impair their performance. Discs are read with a } \\
\text { laser beam, so there is no direct contact or wear on the disc } \\
\text { as it is played. }\end{array}$ \\
\hline Low cost of replication & $\begin{array}{l}\text { Reproduction costs about one dollar per disc after the master } \\
\text { is created. }\end{array}$ \\
\hline Speed & $\begin{array}{l}\text { The cost of CD-ROM drives has decreased dramatically in } \\
\text { the past few years. Many computers now feature built-in } \\
\text { drives. }\end{array}$ \\
\hline programs & $\begin{array}{l}\text { Several thousand commercial titles are now available, } \\
\text { including a wide range of reference materials, multimedia } \\
\text { applications, and government documents. }\end{array}$ \\
\hline $\begin{array}{l}\text { Although the access time of CD-ROM drives is slower than } \\
\text { that of hard drives, the speed of the search time compared to } \\
\text { being introduced regularly (e.g., triple-speed, quadruple- } \\
\text { speed). }\end{array}$
\end{tabular}




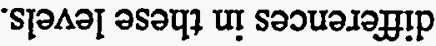

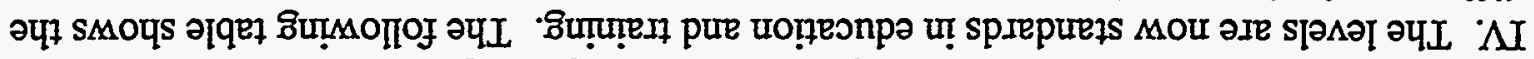

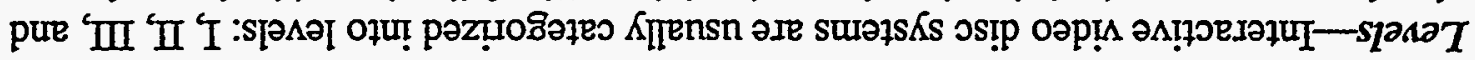

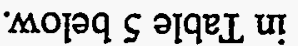

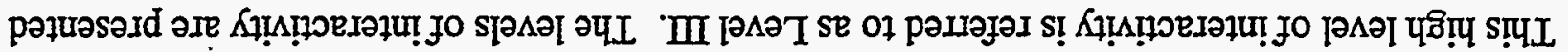

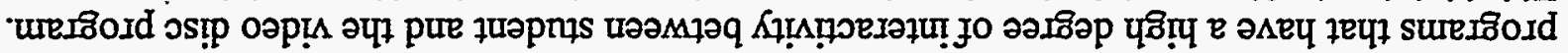

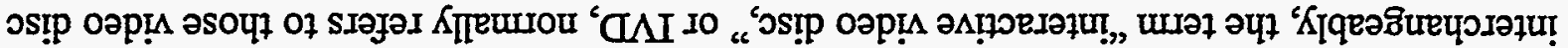

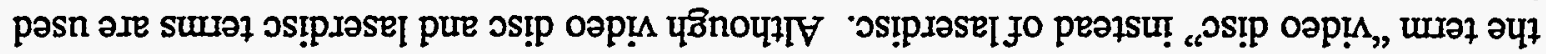

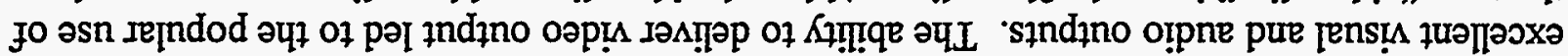

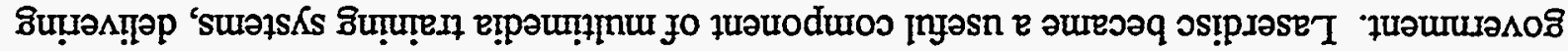

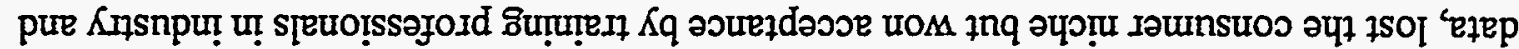

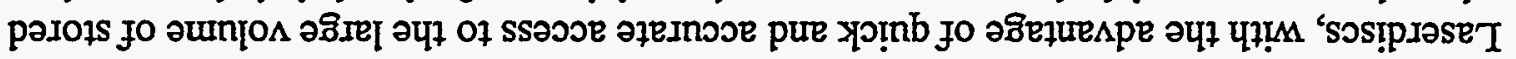

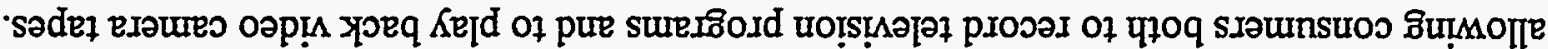
Jo sə8ีełue

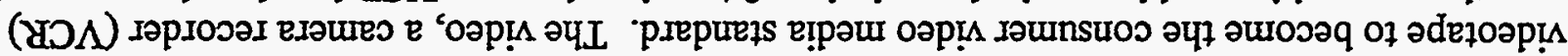

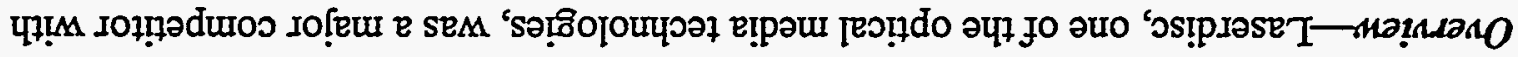

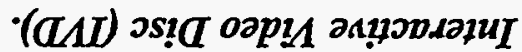

\begin{tabular}{|c|c|}
\hline 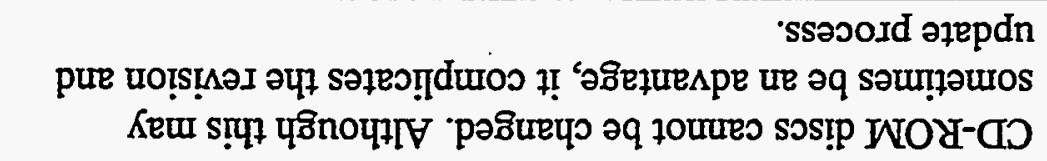 & 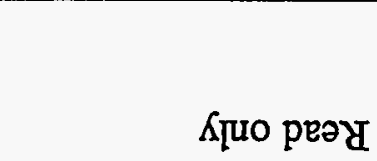 \\
\hline 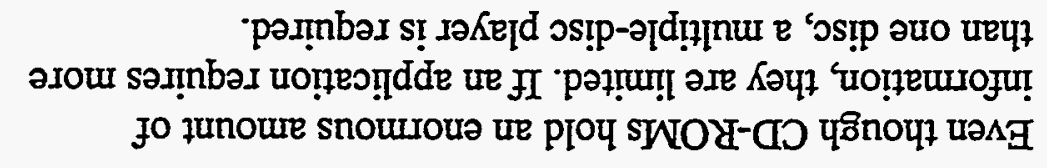 & әdoэs pəł!̣u!T \\
\hline 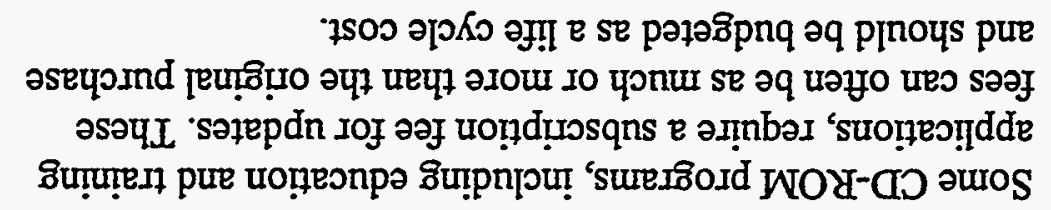 & suọ̣dỵosqus jo 1 so \\
\hline 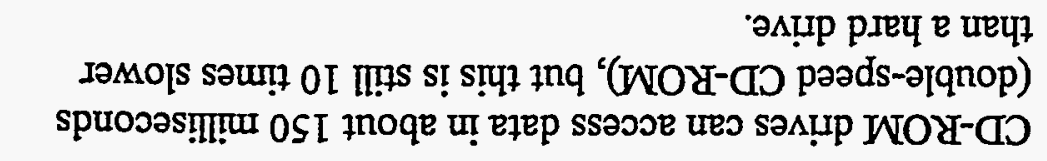 & SSəJวE EユEP MOIS \\
\hline 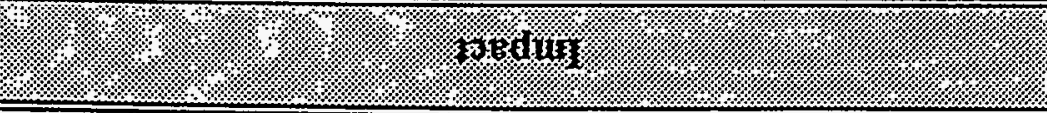 & 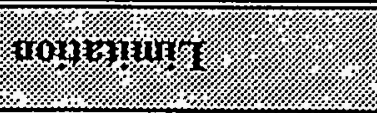 \\
\hline
\end{tabular}


Table 5. TVD interactivity levels.

\begin{tabular}{|c|c|c|c|}
\hline itere. & 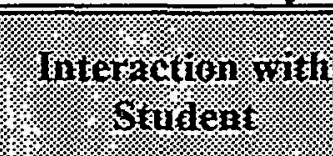 & (4. & : \\
\hline$I$ & $\begin{array}{l}\text { Student's control } \\
\text { similar to that of } \\
\text { VCR user }\end{array}$ & $\begin{array}{l}\text { Monitor, video player, } \\
\text { video disc, optional } \\
\text { remote or barcode } \\
\text { controller. }\end{array}$ & $\begin{array}{l}\text { Player has no memory or processing } \\
\text { power. Used mostly for } \\
\text { entertainment applications. }\end{array}$ \\
\hline II & $\begin{array}{l}\text { Increased } \\
\text { interactivity }\end{array}$ & $\begin{array}{l}\text { Monitor, video disc } \\
\text { player with built-in } \\
\text { programmable } \\
\text { memory, video disc } \\
\text { which includes a } \\
\text { controlling program. }\end{array}$ & $\begin{array}{l}\text { Increased flexibility over Level I. } \\
\text { Offers simple branching: player } \\
\text { stops on multiple choice questions, } \\
\text { student makes choice, player goes } \\
\text { to specific frame for feedback. } \\
\text { Problems: program will not operate } \\
\text { on all IVD players, control program } \\
\text { on disc cannot be changed. }\end{array}$ \\
\hline III & $\begin{array}{l}\text { Flexible, } \\
\text { sophisticated } \\
\text { interaction }\end{array}$ & $\begin{array}{l}\text { Computer, video disc } \\
\text { player, monitor, } \\
\text { related peripherals. }\end{array}$ & $\begin{array}{l}\text { Video disc player is essentially a } \\
\text { computer peripheral. Student can } \\
\text { access a term, image or video. } \\
\text { Level III also uses computer to note } \\
\text { and store student performance. }\end{array}$ \\
\hline IV & $\begin{array}{l}\text { Flexible, } \\
\text { sophisticated } \\
\text { interaction }\end{array}$ & $\begin{array}{l}\text { Computer, video disc } \\
\text { player, monitor. } \\
\text { (Video disc can store } \\
\text { digital data as well as } \\
\text { analog video and } \\
\text { sound.) }\end{array}$ & $\begin{array}{l}\text { Computer-video disc system in } \\
\text { which video disc is used to store } \\
\text { digital data as well as analog. Thus } \\
\text { the video disc player serves as an } \\
\text { added optical storage device to the } \\
\text { computer. }\end{array}$ \\
\hline
\end{tabular}

The IVD Technology. Video discs are a product of optical media technology, which is linked with development of the laser (light amplification by stimulated emission of radiation). Both technologies are necessary both for effective creation and for using the video disc as a data storage medium.

The mastering process to create a video disc begins with the digital information from the master data triggering a laser to expose spots on a thin photographic film coating on a rotating glass plate. The laser can be turned on and off millions of times per second, and this pattern corresponds to the on/off value of the digital bits of data. The exposed spots are acid-etched onto the glass master disc, which is then used to make a metal master disc. The metal master disc is 
then used to impart the pattern onto heated plastic discs. The process is completed with the addition of a reflective surface (to assist the reading of the pattern) and a plastic coating for protection of the disc. The result is a laserdisc capable of storing 54,000 frames, about 30 minutes of video.

With the video disc spinning at high speed, the reading head directs a laser beam onto a selected track, the reflected light is converted into an electronic signal formats the data for the output device. The output can be video, sound, still image, text or data.

Frames are stored on concentric circles on the video disc. The player can display the same frame as long as it is wanted. Users can access each of the 54,000 frames on each side of a disc. If motion is wanted, frames are played at a rate of 30 frames per second and the user views it as full-motion video. The user can step forward or backward a frame at a time, or can scan forward or in reverse at various speeds. The result is that instructors using a video disc system have great flexibility in using an enormous data base.

Two audio tracks are available on all video discs. Flexibility in using the tracks can produce stereo music, or narrations in two languages, or a narration for learners and a narration for instructors, or narrations designed for different student levels.

One limitation of audio on laserdisc is that audio will be produced only if the video disc is playing forward at the standard 30 frames per second. There will be no sound at other speeds or in reverse.

Application of Interactive Video Disc to Education and Training - Video disc systems have been successfully used for instructional programs in applications listed in Table 6 .

Application of IVD to Education and Training-Video disc systems have been successfully used in instructional programs in the following capacities:

- Interactive tutorials

- Instructional games

- Simulations

- Visual and multimedia databases

- Linear documentary presentations.

These applications are described in the following table. 


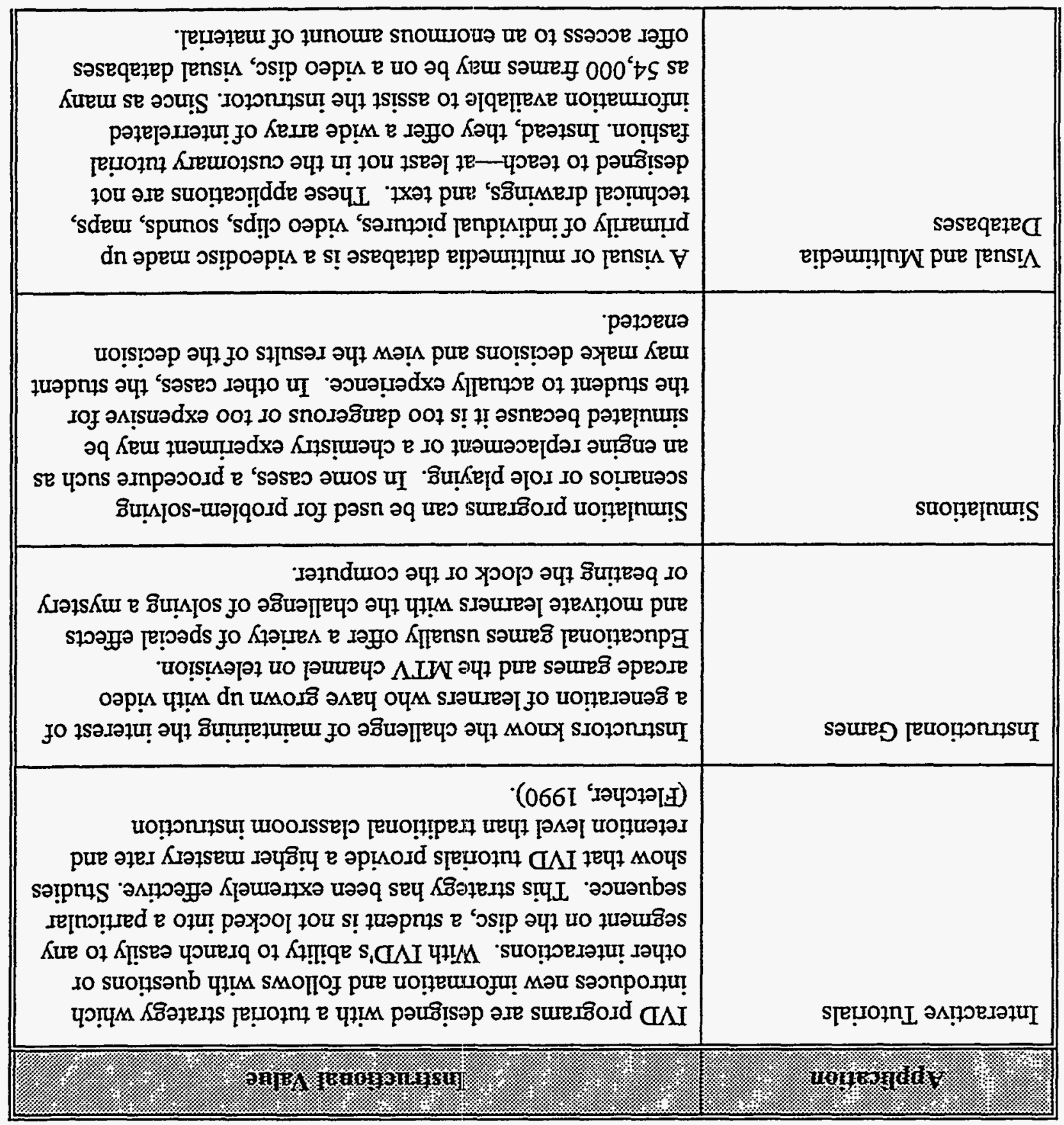

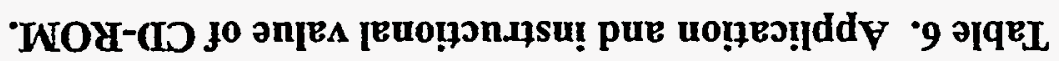


Table 6. Application and instructional value of CD-ROM.

\begin{tabular}{|c|c|}
\hline 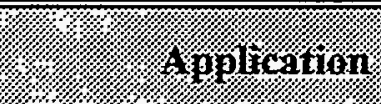 & 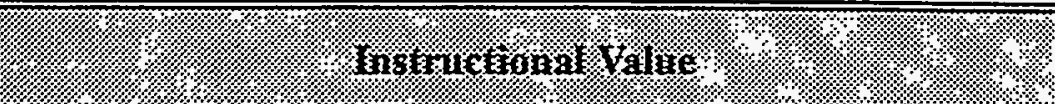 \\
\hline $\begin{array}{l}\text { Linear Documentary } \\
\text { Presentations }\end{array}$ & $\begin{array}{l}\text { Video discs can easily replace } 16 \mathrm{~mm} \text { film libraries, at a } \\
\text { fraction of the cost, without worries about sprocket holes } \\
\text { and rewinding. Video discs do not wear out or degenerate } \\
\text { with repeated use. In addition, many educational films, } \\
\text { documentaries, even commercial movies are available on } \\
\text { video disc at lower prices than on videotapes. And using the } \\
\text { SEARCH option makes any location on the disc available } \\
\text { almost instantly. }\end{array}$ \\
\hline
\end{tabular}

Strengths and Limitations of IVD - Video disc systems have had widespread use in military education and training. Although not the best media selection for all applications, video disc has often been a good choice. The following tables summarize the strengths and limitations of video disc systems.

Table 7. Strengths of video discs.

\begin{tabular}{|l|l|}
\hline \hline Access & \multicolumn{1}{|c|}{ Strengit } \\
\hline Cost of programs & $\begin{array}{l}\text { Fast and precise. Frames and segments can be identified for } \\
\text { presentation through use of a computer, a remote control, or } \\
\text { a barcode reader. }\end{array}$ \\
\hline Durability & $\begin{array}{l}\text { Many commercially-available video disc programs are less } \\
\text { expensive than those on videotape or film (Range: \$50-700). }\end{array}$ \\
\hline Quality & $\begin{array}{l}\text { Images on the disc do not degenerate with use. After years of } \\
\text { use, the video will look as clean and sharp as it did the first } \\
\text { time. }\end{array}$ \\
\hline $\begin{array}{l}\text { Video discs are generally recorded with 350 lines of } \\
\text { resolution. VHS and Beta videotapes are recorded with only } \\
\text { 200 to 250 lines of resolution. Video discs have a sharper } \\
\text { appearance and better-quality picture. }\end{array}$ \\
\hline
\end{tabular}


Table 7. Strengths of video discs.

\begin{tabular}{|l|l|}
\hline Storage & $\begin{array}{l}\text { Video discs are easy to store, take very little shelf space and } \\
\text { will not warp. }\end{array}$ \\
\hline Interactivity & $\begin{array}{l}\text { Unlike videotape or film, it is relatively easy to control a } \\
\text { video disc with a computer. Level III video disc programs } \\
\text { provide the interactivity and instant feedback of } \\
\text { computer-assisted instruction with visual and audio realism. }\end{array}$ \\
\hline Still frame & $\begin{array}{l}\text { Still frames can be halted for hours with no damage. This } \\
\text { provides individual access to every frame on the disc. }\end{array}$ \\
\hline Dual audio tracks & $\begin{array}{l}\text { The two audio tracks on all video discs can be used for } \\
\text { bilingual narrations, stereo sound, or other creative } \\
\text { applications. }\end{array}$ \\
\hline Format standards & $\begin{array}{l}\text { Although there are two different video formats (CLV and } \\
\text { CAV), all video disc players can play all laser standard video } \\
\text { discs. }\end{array}$ \\
\hline $\begin{array}{l}\text { Instructors can use video disc programs already developed, } \\
\text { program them for individual or group use, and select } \\
\text { segments for classroom audiovisual aids. Video discs also } \\
\text { serve as research and reference databases. }\end{array}$
\end{tabular}

Table 8. Limitations of video discs.

\begin{tabular}{|l|l|||}
\hline Cost of programs & $\begin{array}{l}\text { Front-end design and development costs for quality programs } \\
\text { can be expensive. }\end{array}$ \\
\hline Cost of hardware & $\begin{array}{l}\text { Players that interface with computers and provide remote } \\
\text { control units currently cost about } \$ 700 . \text { However, the cost } \\
\text { of video disc players continues to decline. }\end{array}$ \\
\hline
\end{tabular}


Table 8. Limitations of video discs.

\begin{tabular}{|c|c|}
\hline Inimitation & $\{$ वाव \\
\hline Maintenance costs & $\begin{array}{l}\text { As with all equipment, an annual maintenance budget is part } \\
\text { of life-cycle costs. }\end{array}$ \\
\hline Lack of interface standards & $\begin{array}{l}\text { Connecting a computer to a video disc player can be } \\
\text { frustrating. Different players require different interface cables } \\
\text { and speak different "languages." Software programs must } \\
\text { contain appropriate drivers, and baud rates have to be set } \\
\text { correctly. }\end{array}$ \\
\hline Read only & $\begin{array}{l}\text { Video discs are read-only; the user cannot record on the disc. } \\
\text { This is a disadvantage in that student productions or other } \\
\text { creations cannot be recorded or copied. }\end{array}$ \\
\hline Difficult for group instruction & $\begin{array}{l}\text { Without expensive video projection equipment, a video } \\
\text { display is limited to the video monitor size. Level III delivery } \\
\text { with two monitors also has the problem of projecting the } \\
\text { computer screen for group instruction. }\end{array}$ \\
\hline $\begin{array}{l}\text { Computer storage } \\
\text { requirements }\end{array}$ & $\begin{array}{l}\text { If a Level III video disc program is to be used, computer } \\
\text { software will be needed to run the program. In some cases, } \\
\text { the amount of storage space required on a hard drive } \\
\text { approaches } 10 \text { megabytes. }\end{array}$ \\
\hline $\begin{array}{l}\text { Lack of computer } \\
\text { compatibility }\end{array}$ & $\begin{array}{l}\text { Before a Level III program is purchased, check carefully to } \\
\text { determine compatibility. As with other software programs, if } \\
\text { it is written for the Macintosh, it will not run on an IBM, and } \\
\text { vice versa. }\end{array}$ \\
\hline Limited motion sequences & $\begin{array}{l}\text { Up to } 54,000 \text { still frames is a tremendous capacity for video } \\
\text { disc, but when this is translated into motion sequences, the } \\
\text { limit is } 30 \text { minutes, much less than a videotape's capacity. }\end{array}$ \\
\hline $\begin{array}{l}\text { Lack of instructional } \\
\text { materials }\end{array}$ & $\begin{array}{l}\text { To date, instructional materials to support the use of video } \\
\text { disc programs are scarce. In many cases, instructors are left } \\
\text { to their own initiative and creativity to integrate the programs } \\
\text { into the curriculum. }\end{array}$ \\
\hline
\end{tabular}


Table 8. Limitations of video discs.

\begin{tabular}{|l|l|l|}
\hline $\begin{array}{l}\text { Discontinuation of products } \\
\text { by most manufacturers }\end{array}$ & $\begin{array}{l}\text { IVDs are being phased out and may not even be } \\
\text { manufactured within a short time. }\end{array}$ \\
\hline
\end{tabular}

\section{Teleconferencing}

Overview-Telecommunications have made it possible to teach over distances by transmitting either voice or voice and video to and from several locations at once. Teleconferencing is the use of telecommunications technology to link two or more sites for interactive exchange of information. Teleconferencing is growing as a support service for the distribution of learning programs. Capabilities available today are generally in three categories.

- Audio teleconferencing

The most mature of the techniques, audio teleconferencing requires little equipment. Its major drawback is that the lack of visual interaction requires planning to keep the educational process productive.

- Audio-graphic teleconferencing

This variation allows figures, charts, and still pictures to be exchanged during the conference. Computer and fax technologies are used for interactive exchange of images, thus enhancing the free expression of ideas.

- Video teleconferencing

This technique combines full-motion video with audio. Most forms of video teleconferencing still require careful cost justification in educational uses, but costs are declining. Several varieties of video teleconferencing exist.

Six teleconference operational options are explored in Subtopic 1.4 of this report. Several of these options involve non-satellite-based teleconferencing, where telephone lines are used to send compressed digital video signals from desktop to desktop or board room system to board room system.

Applications for Education and Training-The following are examples of teleconferencing used in providing distance learning opportunities.

- Distributed classrooms

Connecting several classroom sites to a location where the teacher is available is often a cost-effective means of delivery. Teleconferencing takes place at a prearranged time for 
interaction between instructor and learners and is often used for adult learners who cannot be gathered at one time and location for classes. Individual learners or groups of learners at a site gather to work with taped programs. The learners are still often able to call someone at the host location if they have questions. Specialized courses or those with a scarcity of teachers are often provided through contracting with outside companies. These courses may be delivered via satellite television with audio teleconferencing for student interaction.

- Utah Education Network (UEN)

Utah Education Network is an organization of public and higher education that began in 1978.

This group represents higher, public, and vocational education, as well as business and industry. Together they have developed the electronic delivery systems. EDNET is a two-way, fully interactive video network that allows students to take classes that might not be available to them in their local community. A teacher can instruct students in many schools from a single classroom, yet everyone can see and hear each other through this interactive network. Fiber optics, microwave, and phone lines are used to deliver this service to over 65 sites statewide. EDNET provides K-12, for-credit college courses, and opportunities for government and business teleconferences. UEN also provides University of Utah students, as well as students at other state institutions of higher education, with access to telecourses, libraries, curriculum materials, national education journals, and even NASA exhibits. Information about EUN and EDNET can be found on the Internet at the following World Wide Web Uniform Resource Locator (URL): http://www.uen.org/.

- Mind Extension University (MEU)

The Education Network is a national broker and unique delivery service primarily of educational programming and degrees from various institutions. Founded in 1987, the network combines the technology of satellite and cable television to deliver a variety of educational opportunities to students at their workplace or directly into their homes. MEU offers approximately 150 credit courses per year at the undergraduate level, 45 at the masters level, and over 150 non-credit courses.

- Educational Network of Maine

Maine provides an example of a statewide network, developed and operated by the University of Maine System, for the benefit of a large number of educational providers and students. The Educational Network of Maine (formerly the Community College of Maine) was implemented in May 1988. The Educational Network of Maine began broadcasting 40 courses over two closedcircuit ITV channels to 47 locations statewide in 1989 for over 2,000 students. Today, the Educational Network of Maine interconnects more than 100 locations in Maine for over 65 credit courses, five full time associate degrees (Business, General Studies, Social Services, Liberal Arts, and Library and Information Technology), and two masters degrees (Industrial Technology and Library and Information Technology). The Educational Network of Maine serves over 4,000 credit students and approximately 20,000 other individuals in meetings, seminars, and non-credit courses each year. 
- Public Broadcasting Service/Adult Learning Services

The Public Broadcasting Service (PBS) Adult Learning Services (ALS) pioneered the widespread use of for-credit telecourses by colleges and universities. Since PBS began operating in 1981, nearly three million students have earned academic credit for telecourses broadcast by 96 percent of the nation's public television stations. Students enroll in a telecourse through the college of their choice, pay the proper tuition, and fulfill the course requirements as specified by the local faculty member assigned to each course. Students usually watch the telecourses when broadcast by their local public television stations. In 1994 alone, AIS delivered 1,000 hours of telecourse programs to stations and colleges. The World Wide Web Uniform Resource Locator (URL) for information about PBS and ALS is http://www.pbs.org/.

- Hewlett-Packard's Distance Learning System

Hewlett-Packard's Distance Learning System delivers training at one-half the cost of traditional classes. Hewlett-Packard's Information Technology Education Network (ITE-Net) is a pacesetter. This system provides instantaneous two-way voice communications (via phone lines and satellite) and one-way video communications (via satellite) between instructors and students. Instructors also receive immediate feedback from compiled student responses to numeric or multiple choice questions through a student response keypad system. In an industry-wide race to master this powerful medium, Hewlett-Packard has developed a network that can leverage limited expertise and can greatly reduce the time to retrain a large, geographically diverse population. The DOE Central Training Academy, prior to completing its own distance learning studio, contracted with Hewlett-Packard to provide similar training capabilities to the DOE complexwide safeguards and security community.

- National Technological University (NTU)

The National Technological University (NTU) has made a giant technological leap by replacing analog transmission with compressed digital video delivered via satellite. The conversion is the first of its kind in the United States to integrate modern instructional technologies over a large, nationwide system. NTU designed an enhanced and proprietary ITV delivery system using the SpectrumSaver Satellite Based Broadcast Television System developed by Compressed Labs, Inc. It is an integral step to on-demand education at the workstation. NTU offers Master of Science degrees in ten engineering fields. It has 41 participating universities and 385 sites in 130 organizations. The World Wide Web Uniform Resource Locator (URL) for information about NTU is http://www.ntu.edu/. 
Comparison of Teleconferencing Techniques-Teleconferencing has progressed to the point that it can be an effective addition to education and training, especially when instructors are few and learners are widely dispersed. Table 9 summarizes the features of teleconferencing techniques.

Table 9. Teleconferencing techniques.

\begin{tabular}{|c|c|c|c|}
\hline 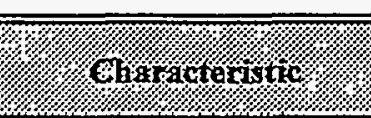 & i. & 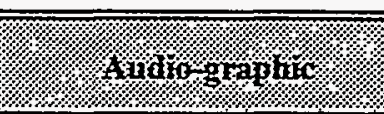 & 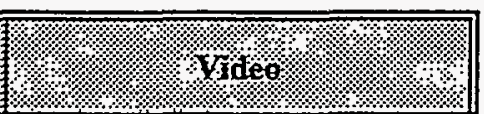 \\
\hline Features & $\begin{array}{l}\text { Two-way } \\
\text { audio }\end{array}$ & $\begin{array}{l}\text { Two-way audio } \\
\text { Two-way still images }\end{array}$ & $\begin{array}{l}\text { Two-way audio } \\
\text { One-way or two-way } \\
\text { video images }\end{array}$ \\
\hline Course content & $\begin{array}{l}\text { Highly } \\
\text { verbal }\end{array}$ & Verbal/Visual & Visual \\
\hline Teacher training & Slight & Moderate & Extensive \\
\hline Planning & Five days & One month & One year \\
\hline Class location & $\begin{array}{l}\text { One or many } \\
\text { sites }\end{array}$ & Two sites & One or many sites \\
\hline Student interaction & Verbal & Verbal or still image & Verbal or video \\
\hline $\begin{array}{l}\% \text { of Total Class } \\
\text { Time }\end{array}$ & $10-15$ & $30-60$ & $75-100$ \\
\hline Relative costs & Low & Moderate & High \\
\hline
\end{tabular}


Strengths and Limitations-The following tables describe some of the primary strengths and limitations of teleconferencing.

Table 10. Strengths of teleconferencing.

\begin{tabular}{|c|c|}
\hline $1.1 \%$ Sreagnil & $4 \operatorname{limp} \%$ \\
\hline Cost steadily declining & $\begin{array}{l}\text { The future of teleconferencing is bright, especially as the } \\
\text { logistics, availability and overall cost-requirements continue to } \\
\text { drop. }\end{array}$ \\
\hline Live classroom interaction & $\begin{array}{l}\text { Perhaps the primary strength of teleconferencing is its ability } \\
\text { to create a virtual classroom with participants located } \\
\text { throughout the country or world. Many of the interactions } \\
\text { that make classroom teaching so powerful are preserved even } \\
\text { though the students are not in the same physical space. When } \\
\text { the students have questions they can ask them, real time. } \\
\text { Similarly, instructors can ask for input from the entire class or } \\
\text { specific students. Canned instructional material lacks this } \\
\text { real-time interaction. }\end{array}$ \\
\hline Video & $\begin{array}{l}\text { If video is used, it provides the ability to communicate } \\
\text { visually. Body language of the instructor may be useful in } \\
\text { maintaining interest. Graphics and other visuals may be } \\
\text { broadcast real-time. }\end{array}$ \\
\hline Pacing & $\begin{array}{l}\text { One of the strengths of much classroom instruction is that it } \\
\text { moves students along. }\end{array}$ \\
\hline Sense of community & $\begin{array}{l}\text { Teleconferencing is remarkably powerful at bringing virtual } \\
\text { classes together, sometimes even better than in co-located } \\
\text { classes. }\end{array}$ \\
\hline
\end{tabular}


Table 11. Limitations of teleconferencing.

\begin{tabular}{|c|c|}
\hline 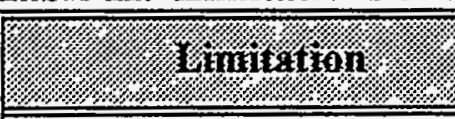 & T. \\
\hline Teacher comfort and skill & $\begin{array}{l}\text { A major limitation is the time and effort required to create } \\
\text { smooth and well-polished courses. Instructors not used to } \\
\text { teaching via teleconferencing must learn to accommodate to } \\
\text { this new medium. Some instructors never adjust. }\end{array}$ \\
\hline Scheduling & $\begin{array}{l}\text { All participants are required to meet at the same time. For } \\
\text { nationwide or worldwide classes, the number of time zones } \\
\text { represented pose some serious scheduling challenges, } \\
\text { especially for lengthy courses or meetings. Videotaping and } \\
\text { replaying the videotapes defeats many of the other strengths. }\end{array}$ \\
\hline Problems & $\begin{array}{l}\text { Frequently there are unexpected problems with the hardware } \\
\text { or communications networks. However, reliability seems to } \\
\text { be improving. }\end{array}$ \\
\hline $\begin{array}{l}\text { Logistics, facilities, and } \\
\text { facilitators }\end{array}$ & $\begin{array}{l}\text { Logistics and overall cost are also a limitations. Various } \\
\text { forms of teleconferencing are cheaper than others, but all } \\
\text { forms require some special equipment, instructor training, } \\
\text { technical support, and assistance at both the sending and the } \\
\text { receiving ends. Fortunately, costs are coming down steadily. }\end{array}$ \\
\hline Preparation & $\begin{array}{l}\text { Extensive preparation of visuals, scripts, and handouts are } \\
\text { often required. }\end{array}$ \\
\hline
\end{tabular}

\section{Computer Networking}

Overview-The networking of computers has expanded rapidly from modem dialup to time sharing computers to local area networks (LAN) and wide area networks (WAN) to the Internet. Simply stated, networking and computer mediated communications are changing the way Americans live and work and recreate. As many workers are starting to work at home, similarly, learners can learn at home or in their office as effectively as in a classroom with networks. Through telecommunications, learners can tap into information and training resources all over the country. Subtopic 1.4 describes four specific networking configuration options.

The expansion of the information super highway has received almost constant national attention as Internet participation has skyrocketed and membership in online services has rapidly increased. This kind of computer to computer connectivity is leading to more acceptance of asynchronous (not at the same time) computer conferencing discussions, called "news groups" on Internet or "discussion groups" on other online services. In addition to Internet capabilities, 
popular software products (such as Lotus Notes) support many important networking features including E-mail and synchronous and asynchronous discussions.

Where Internet access is becoming almost universal at most major universities, within government, and increasingly so in business and industry, many organizations already have most of the hardware and even some of the software they need to support online asynchronous courses. As Internet and other network use continues to expand, it is likely that more sophisticated and user-friendly forms of computer networking will evolve as a low-cost, easy-to-implement alternative to the more expensive multimedia options. In addition to asynchronous computermediated communications, some systems can be tailored to support a limited amount of synchronous (all at the same time) conversations. As bandwidth and software support become more powerful, it is becoming easier to connect not only the computers for synchronous text and graphics-based conversations but the video camera as well-hence desktop video teleconferencing.

Extensive commercially funded research continues to develop network-based systems that allow teams to create and modify documents, programs, business plans, etc., interactively. Some significant breakthroughs in this area would tend to add to the acceptance of the computer mediated courses already discussed and move them in interesting directions-perhaps toward more combined work/learning projects for which experts are brought in to teach specific concepts and skills as part of an ongoing work project. This is a group version of "just in time" training that is becoming more and more popular in multimedia circles.

Local Area Networking ( $L A N)$ Details-Most managers will not be directly involved in the design and installation of a computer network. The basic rule is to involve an expert. However, the manager will benefit from understanding the basic design, hardware and software presented in this section.

Although many considerations must be taken into account when designing a site network, two major considerations are:

- The "topology," the shape a network takes when illustrated on paper. Common topologies include the star, ring, tree, and line. Each has strengths and weaknesses, and the application of the network becomes the deciding factor.

- Data speed (the rate at which different networks can transfer data) varies by network. When an expert can design higher data transfer rate into the network, more workstations can be used at the same time. Generally, the more users on a network, the slower the data transfer rate. However, many factors beyond number of users are considered by the experts.

Computer network experts are likely to develop hybrids of the topology and cabling outlined above. Hybrids are often most effective, especially when location of workstation and servers, frequency of equipment change, and existing facility considerations are weighed. 
Beyond the computer workstations themselves, several hardware elements must be considered in networking. The most important are discussed below.

- The cabling that physically links the elements of the network is also a matter of design requirements and cost. For example, the total amount of cable required varies with the topology; but additional cable can create redundant paths so the network will remain operational even if one section of cable is damaged. A description of three common cable types, from least to most expensive, follows:

-- Twisted pairs. The wiring literally has two wires twisted together and is the same as that commonly used for telephone lines. If unused telephone lines exist in the building where the network is to be installed, they could be used to link computers. Twisted pairs are significantly vulnerable to interference that can disrupt the network.

-- Coaxial cable. This cable is similar to that used for television signals. The same coaxial cable can support network and television signals simultaneously. Coaxial cable is almost immune to external interference, but is expensive.

-- Fiber-optic cable. This cable has fine fibers of glass rather than metal wiring inside. Light, not electricity, is conducted. It offers very-high-speed data transmission, including video and audio capabilities in the same cable. It is immune to all forms of electrical interference because no metal is present. Fiber-optic cable is expensive, difficult to install and to modify.

- Network interface cards must be added to each computer in the network. The cards affect the topology, cabling, and data transmission of the network. Many networks are named for the cards. For example, one IBM card package for a ring topology and token-passing data protocol is named "Token Ring." Other well-known packages are Ethernet and Arcnet. No two systems are directly compatible, but techniques do exist to bridge individual networks of different types.

- The file server is the computer that serves the network as both repository for all applications software programs and as traffic director for files going to workstations. Because of the critical role of the file server, there should be no compromise on file server features.

- A printer server is the network's computer dedicated to managing the printing function between all computers and printers on the network. An older or minimum capability computer will normally handle the printer server duties.

- Workstations are standard computers with a network interface card installed and used by a worker. A hard disk drive on a workstation is redundant; the network server serves the purpose. However, workstations that require stand-alone capabilities will have hard disk drives. 
Internet Networking-The Internet is a network of networks that allows users to be hardwired into or dial into one network, essentially a worldwide access. The Internet has been growing at an astounding rate for several years as more and more institutions are being connected. Among the most basic features of the Internet is "Telnet," the ability to log on to another computer on the Internet and run a program on that computer. Another basic feature is the ability to transfer files to and from other computers on the network. The Internet also offers E-mail and news groups. More advanced are programs running on network computers that serve as special file servers. Two such programs are becoming very popular: Gopher servers and World Wide Web servers. This latter server is relatively new and uses a graphical user interface styled after hypermedia. Each web server has a home page with various icons and hot spots which allow the users to branch to files, run programs, download and view images or video clips and so forth. Currently, the World Wide Web is enjoying the fastest growth of any Internet resource because it is easy to use. The user merely points and clicks to gain access to an exponentially increasing source of information, such as full text DOE Orders, Secretary of Energy Notices, Code of Federal Regulations, Commerce Business Daily, and conference proceedings (e.g., the DOE Low Level Radioactive Waste Management Conference [URL=http://www.inel.gov/.llrw/] and the World Wide Web Conference proceedings [URL=http://www.elsevier.nl/cgi-bin/ID/wWW94]). Numerous publications are available in any bookstore describing these and other features of the Internet.

Application to Education and Training-Straight networking via a LAN or WAN can bring many advantages. A host of further applications follow with Internet and computer mediated communications features such as E-mail, news groups, electronic mailing lists, computer conferencing, World Wide Web, Gopher servers, file transfer, and so forth. Some of these are detailed below:

- Although the initial investment in a LAN can be high, the operation of a well-used, properly designed and maintained LAN will cost less over time than will the operation of a group of stand-alone computers. LAN advantages include: 1) instructor monitoring of student work; 2) developer access to software and files; 3) student access to references and databases; 4) group-study classroom projects; and 5) school management enhancements.

- A properly configured network will allow the instructor to monitor each student's work. This provides feedback to the instructor and allows affirmation or further instruction for the student. Course materials can include tests at appropriate junctures, administered over the network, with tracking of individual scores and automated recordkeeping. The student and instructor need not be at the same location.

- The use of a network will provide many benefits to a school or training facility. For example, course developers, by sharing development software and reference materials and jointly developed files, can increase their productivity through use of a network. And learners no longer have to relocate to access reference materials and databases previously available only by moving to a central location. The network serves as the bridge to the sources which can be 
shared by many learners simultaneously. Groups of learners can be teamed to work computer-assisted projects. Team members can share text, graphics, and input from reference sources. The network allows the work to continue, even if the learners are not in the same classroom.

- The network's linking of student machines with the instructor machine, and all machines with the administration office, can be used to automate many of the administrative functions required: grade/progress tracking and recording, attendance, time logged, references used, and so forth.

- The purchase and control of software programs is also simplified by a network. A site license allows a centrally stored program to be shared with many users on the net. Some networks also have an automated means of inventorying all equipment connected to the net.

- It is easy to add subject matter experts to online class discussions, without requiring the expert to travel to the school.

- Homebound or remotely based learners can be connected to the online class.

- Distance tutoring is supported by connecting tutors and learners who need additional assistance, even after class time.

- Although not a training or education-focused project, the Internet deserves special mention because it is rapidly becoming the most significant means for accomplishing network training and education activities. The Internet is as a global network of networks, users can "talk" to colleagues worldwide. The Internet uses the high-speed capabilities of the National Science Foundation's NSFnet (the backbone of the Internet) to link various local, regional, national, and international networks. Many of the network educational services use the Internet. Increasingly, access to the Internet is the key part of plugging into the world of networking and information sharing. Currently, it is estimated that over 30 million people use the Internet, and the number of nonprofit and commercial services offering Internet connections is growing rapidly every day. Thus trainers and educators seeking to become involved with networking and information sharing should seek access to the Internet.

- Group learning at a distance is supported. The Department of Defense conducted an experiment in early 1994 illustrating this capability over the Internet. Given special allocation of network resources that were far beyond what is normally available, high school students in several distant parts of the world (U.S., Germany, and Korea) were able to play band music together in "almost real time," conduct flight simulation experiments together, and interact together in multimedia classwork. 
- Several organizations have experimented with computer networking and computer-mediated communication over the last decade. It has been used effectively in Canada as a major support to distance learning (e.g., University of Athabasca) and in Great Britain as part of the Open University system. Several masters level programs have been conducted in the United States using this format, including one at Boise State University in Instructional Systems. E-mail-assisted correspondence programs are becoming more commonly available, improving students' access to help. Within this format, the students communicate with instructors individually via E-mail and together as a class or small groups via list servers, news groups or computer conferences.

- One particularly informative use of computer-mediated communication was the integration by the Army Reserve of several distance learning and rnultimedia modules into a course taken by Reserve Engineering Officers from their homes. The soldiers learned from a wide variety of media including multimedia presentations, CBT, writing essays using the computer's word processor, spreadsheet-based engineering exercises, exams, whole-class and small group (team) discussions, and messaging the instructor or classmates for one-on-one tutoring. All the results and student progress were automatically forwarded to the instructor via the network.

- Free Educational Electronic Mail Network (FrEdMail) was initiated in 1986. This is the oldest and largest education network in America, linking through the Internet more than 150 electronic bulletin boards (called electronic mail centers) operated by individuals and institutions. Each bulletin board represents a "node" on the system and delivers E-mail to as many as 300 teachers and students. The teachers and students participate in a wide variety of learning experiences designed to motivate students to become better learners and writers. FrEdMail is also intended to promote the sharing of resources and experiences among teachers.

- The Department of Energy (HR-2) has implemented an electronic mailing for DOE trainers to use for sharing training-related information using electronic mail (E-mail). The system allows users to "subscribe" to the mailing list. Once subscribed, every user will automatically receive all E-mail that is addressed to the mailing list. The mailing list is intended to provide a "justin-time" mechanism for sharing training information, resources, computer files and programs, and requests for training course materials and resources. ${ }^{2}$

\footnotetext{
2 To subscribe to the DOEIRAINER mailing list, send an E-mail message to "majordomo@wastenot.inel.gov," without the quotation marks or comma. In the message body, type "subscribe doctrainer," without the quotation marks or comma. Do not include any other text, such as a personal signature. The system automatically E-mails a response to inform the user that the subscription request was successful, and then a second E-mail message containing the system guidelines/information document. After having subscribed to the mailing list, address E-mail messages to "doetrainer@wastenot.inel.gov," and the system will automatically forward your message.
} 
- The Department of Energy (HR-2) has also established a Training Information Clearinghouse to provide DOE Federal and contractor training organizations with a central access point for training course catalogs, course descriptions and schedules, DOE Orders and Safety Guides, DOE Standards and Guidelines, as well as the texts of complete training courses and seminars, the Operations and Training Spectrum newsletter, and other training-related information. Rather than having one DOE organization maintain one large, unmanageable computer system for the DOE complex, each DOE training organization will provide a similar World Wide Web interface for sharing their training materials and information within the DOE community. As the Training Information Clearinghouse expands, it will become the central training World Wide Web server for a DOE trainers. The Training Information Clearinghouse allows for true sharing of information within the DOE complex. The Uniform Resource Locator (URL) for the DOE Training Information Clearinghouse is http://wastenot.inel.gov/training.

- The Distance Learning Resource Network (DLRN) provides a national information clearinghouse for educators and agencies to support planning and implementation of distance learning programs. The DLRN database is accessible via the Internet for a wide array of information. Plans are in progress to make it available via commercial providers. Resources include information about distance learning programs, planning and evaluation resources, funding, staff development, research, policy reports, legislation, computer conferencing, instructional techniques, model programs, classroom design, and other information.

- The Blacksburg Electronic Village (Blacksburg, VA) links together many individuals and groups in the community, such as elementary and secondary students and teachers; people in businesses and professional services; Virginia Tech students, staff, and faculty; civic groups and those who seek to serve; and individual citizens. The network provides access to Internet, electronic mail, worldwide electronic discussion groups, information databases, and a wide range of educational, financial, business, health care, library resources, and general communication services. The Blacksburg Electronic Village World Wide Web site serves as a national model for future "electronic villages" that are emerging around the nation. Many Virginia Tech students, staff, and faculty already own personal computers. The university has installed its own voice, video, and data networks throughout the campus and residence halls. Computers are needed to participate efficiently in the electronic village network. The Uniform Resource Locator (URI) for the Blacksburg Electronic Village is http://crusher.bev.net/.

- The new National Research and Education Network (NREN) will build on the existing networks, and the existing Internet will be its backbone. NREN has stirred the imagination of people in government, industry, training, and private sector as a network that will eventually be as commonplace as the telephone system. In November 1991, Congress set up the High Performance Computing (HPC) program which will involve many government agencies, including the National Science Foundation, National Aeronautics and Space Administration, Department of Energy, and Defense Advanced Research Projects Agency. Part of the HPC program's goal is to build the NREN. The network will reach beyond the United States to serve a new world where a deliberate limitation of knowledge and information will not exist. 
To realize the full benefit of the information age, these high-speed networks must tie together millions of computers, providing capabilities that are almost unimaginable. NREN's speed will enable extensive use as it will eventually be able to handle speeds of at least one gigabyte per second. The Internet is currently spread over about 35 countries, with more than two millions users logging on each day. Internet traffic is increasing at a rate of over 1,000 percent per year, indicating the need for a high-speed network. The Internet currently lacks the speed to share large volumes of information and research data, but NREN will help solve this problem.

Strengths and Limitations-Networking computers effectively broadens the capabilities of computer users, but there are also potential disadvantages. The following tables detail the strengths and limitations of computer networking.

Table 12. Strengths of computer networks.

\begin{tabular}{|c|c|}
\hline Connectivity & $\begin{array}{l}\text { Networks offer efficiency through connectivity. All network } \\
\text { workstations can share hardware and software resources, } \\
\text { including printers, programs and information in databases. } \\
\text { Massive improvements are possible in accessing databases, } \\
\text { files, other remote computers, etc. }\end{array}$ \\
\hline $\begin{array}{l}\text { Centralized management of } \\
\text { learners }\end{array}$ & $\begin{array}{l}\text { If computers are used in an instructional setting, the network } \\
\text { allows a centralized approach to managing the learning } \\
\text { process. A courseware management program allows an } \\
\text { instructor to evaluate the progress of any learner. Notes can } \\
\text { be left for individual learners, and teachers can interact } \\
\text { directly with learners who are currently working on the } \\
\text { network. }\end{array}$ \\
\hline $\begin{array}{l}\text { Integration of various } \\
\text { elements of instruction }\end{array}$ & $\begin{array}{l}\text { Resources can be orchestrated through a form of computer } \\
\text { managed instruction over the network. }\end{array}$ \\
\hline $\begin{array}{l}\text { Control of software against } \\
\text { pirating }\end{array}$ & $\begin{array}{l}\text { Because all applications software programs are stored and } \\
\text { managed through the file server, network management } \\
\text { software controls access to the software. It is even possible } \\
\text { to install diskless workstations that make it impossible to } \\
\text { copy programs or to infect the system with computer viruses. }\end{array}$ \\
\hline
\end{tabular}


Table 12. Strengths of computer networks.

\begin{tabular}{|c|c|}
\hline 1. & (1. \\
\hline $\begin{array}{l}\text { Ease of updating or adding } \\
\text { software }\end{array}$ & $\begin{array}{l}\text { Software is easy to update or change because only one copy } \\
\text { of each program exists on the file server. Only the file server } \\
\text { copy need be updated. All workstations use that single copy } \\
\text { of the software. }\end{array}$ \\
\hline Convenience & $\begin{array}{l}\text { Computer networking rates high on convenience because the } \\
\text { classes can be taken right to the learner's workstation, home } \\
\text { office, or kitchen table. }\end{array}$ \\
\hline $\begin{array}{l}\text { Supports abstract and verbal- } \\
\text { oriented content }\end{array}$ & $\begin{array}{l}\text { The abstract nature of the written text makes computer- } \\
\text { mediated communications more compatible with the more } \\
\text { verbally-oriented topics such as literature, history, } \\
\text { psychology, philosophy, etc., that are already text-based. }\end{array}$ \\
\hline $\begin{array}{l}\text { Computer conferencing is } \\
\text { self-documenting }\end{array}$ & $\begin{array}{l}\text { Because everything communicated is transmitted and stored } \\
\text { as text, an entire dialog is captured as it takes place. }\end{array}$ \\
\hline $\begin{array}{l}\text { Computer conferencing } \\
\text { allows equal opportunity to } \\
\text { contribute }\end{array}$ & $\begin{array}{l}\text { In addition to not requiring everyone to be together at the } \\
\text { same time or place, computer networking tends to be a } \\
\text { leveler in that everyone has an equal opportunity to enter } \\
\text { their ideas and responses into the group conversation. }\end{array}$ \\
\hline $\begin{array}{l}\text { Networking can foster group } \\
\text { and interpersonal interactions }\end{array}$ & $\begin{array}{l}\text { The ability to preserve many of the positive aspects of live } \\
\text { classes in terms of learning from and interacting with peers } \\
\text { and an instructor is actually a major strength that computer- } \\
\text { mediated communication has over stand alone (IVD or CD- } \\
\text { ROM) multimedia. }\end{array}$ \\
\hline
\end{tabular}


Table 13. Limitations of computer networks.

\begin{tabular}{|l|l|}
\hline \hline File server failure & \multicolumn{1}{|c|}{} \\
\hline Cable damage & $\begin{array}{l}\text { Perhaps the greatest weakness in any LAN is that a failure in } \\
\text { the file server will stop the whole system. However, proper } \\
\text { attention to LAN maintenance will prevent most serious } \\
\text { problems from happening. }\end{array}$ \\
\hline Daily system management & $\begin{array}{l}\text { Problems with network cables can cause anything from minor } \\
\text { interruptions to failures. Large, complex LANs might } \\
\text { require complex diagnostic tools to locate and correct cable } \\
\text { problems. }\end{array}$ \\
\hline High initial installation cost & $\begin{array}{l}\text { Networks need daily management and maintenance planning. } \\
\text { New users must be registered before they can use the LAN. } \\
\text { Software must be updated or added on a regular basis. } \\
\text { Minor problems with printers must be corrected before } \\
\text { unmanageable backlogs of print requests accumulate. }\end{array}$ \\
\hline Competition for resources & $\begin{array}{l}\text { A network can be expensive to install. The apparent high } \\
\text { price of a LAN can be misleading, though, because the actual } \\
\text { cost of operating the same number of unconnected } \\
\text { computers is usually even higher. }\end{array}$ \\
\hline Rapid change & $\begin{array}{l}\text { Many Internet resources such as Veronica, a master index of } \\
\text { Gopher server file contents around the world, have become } \\
\text { so overused that it may be almost impossible to access them. }\end{array}$ \\
\hline $\begin{array}{l}\text { Internet users are frequently in for surprises as features die } \\
\text { away while new ones seem to burst suddenly onto the scene. } \\
\text { It is constantly changing. New information is being added all } \\
\text { the time but old hosts are pulling back. }\end{array}$ \\
\hline
\end{tabular}


Table 13. Limitations of computer networks.

\begin{tabular}{|l|l|}
\hline \hline $\begin{array}{l}\text { Text-based computer } \\
\text { conferencing must be } \\
\text { facilitated }\end{array}$ & $\begin{array}{l}\text { Experience has shown that unlike many other Internet } \\
\text { interactions which are chaotic and self-governing, computer } \\
\text { networking-based courses must have expert moderators to } \\
\text { move the classes along, provoke and facilitate discussion, and } \\
\text { help prevent and resolve problems common to this type of } \\
\text { communication. Peopleware (good facilitor help) is often } \\
\text { harder to acquire than the hardware, software, or } \\
\text { courseware. Additionally, courses that have been taught live } \\
\text { or even via correspondence sometimes require considerable } \\
\text { modification when taught via computer conferencing or E- } \\
\text { mail. }\end{array}$ \\
\hline Connection to the Internet & $\begin{array}{l}\text { The Internet is growing rapidly and access is improving, but } \\
\text { it is still far from universal (as with the telephone, many } \\
\text { classrooms simply do not have access). It is possible that } \\
\text { services through the Internet now available on an unlimited } \\
\text { basis for one low monthly rate may become more costly, } \\
\text { especially if a pay-per-use system is widely instituted. }\end{array}$ \\
\hline $\begin{array}{l}\text { Text-based computer } \\
\text { conferencing, news groups, } \\
\text { and E-mail communications } \\
\text { may require extended periods } \\
\text { of time }\end{array}$ & $\begin{array}{l}\text { Running courses or carrying on group conversations via the } \\
\text { network can be tediously slow compared to live courses or } \\
\text { even multimedia-based courses. These courses require a } \\
\text { significant amount of reading. }\end{array}$ \\
\hline
\end{tabular}

\section{Courseware Applications}

Overview-First, computer hardware existed (originally relays made of electronic tubes), then software (originally on paper tapes and punch cards), and then several years later, courseware came into being. Courseware is the term for software programs and data specifically tailored to teach and train. Computer-Based Instruction (CBI)/Computer-Based Training (CBT) are programs designed to help people learn. CBT had its beginning approximately forty years ago with Skinners teaching machines and programmed learning. Since then, numerous main-frame, mini, and PC-based courseware applications have been developed. 
The goal of freeing course instructors of the chore of presenting information is a noble one. Computers can surpass the patience of Job in repeating key points (in several different ways), providing examples and needed drill and practice, and in providing coaching and help. To shift the repetitive load from the instructor to the computer has been a goal for CBT from its inception. Instructional designers have attempted to harness the great potential of computers to achieve this objective. To date there are some notable successes, though not as many as anticipated. The most successful programs have been based on careful needs analysis and design. These development processes have been more important than the hardware or software technologies employed. It is easy to take bad classroom instruction and computerize it, and the result is bad CBT. Conversely, it is often possible to take a skill or topic that is almost unteachable in the classroom and through good design and development, create courseware that works.

The following briefly describes several of the most important types of courseware applications that effectively teach and train:

\section{Computer Managed Instruction (CMI) and Computer Adaptive Testing}

(CAT) - Originally developed for the military, CMI and CAT were administered in large, individualized study centers where learners could take written tests and have the results scanned and scored and then receive the next learning assignment. Now, many courseware packages come with a management and secure testing component. $\mathrm{CMI}$ involves tracking and directing students through a set of modules within a course based on their performance in learning activities and tests. Pretesting may indicate that entire modules or segments within modules may be skipped, or it may indicate the need for taking remedial modules before attempting the main course. By tailoring the course to the student, significant time savings can result as well as improved learning effectiveness-students get what they need when they need it.

The concept of CAT is to choose just the right test items to assess an individual's current knowledge or skill level efficiently and reliably. Test items are selected strategically from a large pool. Failure on one item or set of items prompts the selection of other items to confirm the deficiency and so forth until a good training prescription can be made.

\section{Electronic Slide Shows, Hypertext, Drill and Practice and Computer-Based Training} (CBT) - Subtopic 1.3 of this study describes four types of multimedia. The taxonomy presented applies to most types of computer-based instruction and not just multimedia. Perhaps the most basic form of CBT uses the computer to present electronic slide shows. This may be as effective as using overheads or slide projectors and is probably more entertaining. This kind of instruction is linear. While it is adequate for previewing and reviewing material, it is not adequate for teaching new skills or complex concepts. At its worst, this form of CBT is called electronic page turning and is a direct replacement of traditional overhead or slide-presented lecture methods.

Hypertext and hypermedia tools are inherently more powerful and interesting than linear presentation courseware. Individuals can use these tools to browse knowledge bases to find what they need. Hypertext involves key word searches and even more important, associative links 
between words and concepts. Many multimedia encyclopedias involve hypertext (where words are linked) and hypermedia (where still visuals, video clips, and audio sound bites are also linked). Those words that have links to other media or other articles in the encyclopedia are highlighted and can display the graphic, play the video clip, make the sound, or branch directly to some other article. This approach is effective because our brains appear to store and retrieve information through associative links. Hypertext allows for innate curiosity to motivate learning as students are encouraged to wander through various richly intertwined knowledge networks. The World Wide Web (WWW) is the fastest growing Internet resource and has a friendly hypermedia-style interface.

Drill and practice courseware, like electronic slide shows and hypertext, definitely has its place. Many skills require extensive practice and the computer can be the ultimate in perseverance, patience, reality-based decisionmaking and individual responsiveness. When it is important to be able to recognize or recall facts, concepts, or procedure steps, computer drill and practice can be extremely effective in providing sufficient practice to bring about mastery. But if higher level cognitive skills are needed, this kind of courseware will be inadequate.

CBT can also refer to courseware that is more cognitively oriented and applies the principles of learning psychology in presenting case studies and more abstract concepts, rules, and principles. Many instructional strategies may be employed to help the learner grasp new knowledge and acquire new skills. For example, the courseware author can create frames of instruction that include presentation of the facts, concepts, procedures, rules and principles, along with examples and practice items. Branching is often possible based on the learner's performance (i.e., during practice or testing) or under the learner's control, but the rules for this branching must be built in or the controls allowing the learner to branch must be explicitly made available.

Recently, group-based CBT has become easier to manage with video projection or high intensity overhead projection using color LCD panels. Extremely clever courseware has been developed using IVD to help students understand the context within which math or other types of problems occur. Then together as a class, using the CBT or with the help of the instructor, the students seek the rules and procedures needed to solve the cases presented. This situational learning approach appears to have extraordinary power in motivating the learning of new skills and in promoting retention and transfer.

Intelligent Tutoring Systems (ITS)-Artificial intelligence (AI) can model the student's learning, dialogue with and coach the student, or recommend future learning activities. Adding an AI component to CBT creates, usually at great expense, an intelligent tutoring system. Some remarkable ITSs have been developed to diagnose and correct math, physics, steam propulsion, and highly technical procedural skills (such as for NASA). While one would expect more ITSs to be available than are, this may be due to the expense (they are extremely labor intensive to develop), plus the unique skills required of their creators. Or, perhaps there are just not that many subjects that are well enough understood or structured to be compatible with the rigor required by ITSs. A similar problem exists for expert systems where it is not possible to 
create one unless there are true experts who agree about how things work. The military has developed some prototype troubleshooting ITSs (e.g., Sherlock) which have successfully reduced the time required to develop high levels of expertise.

Electronic Performance Support Systems (EFSS)-About five years ago, performance engineers realized that much of what is trained in classrooms is forgotten before the learners get back to the job. They started investigating tools that could be put in the workers hands, on the job, that would provide them with training, coaching, and performance assistance when the need arose. The setting in which EPSSs are used, the assumption that workers can be learners (in a second's time), and that technology can be brought to bear on real problems, distinguishes EPSSs from CBT and ITSs. Full-featured EPSSs will often include CBT, coaches/advisors, ITSs, as well as E-mail and online networking capabilities. Iike ITSs, EPSSs are expensive to develop. However, they have remarkable potential. One computer giant has made it a policy to consider building an EPSS before contemplating standard courseware development options.

Simulation-When the goal of the courseware is to teach something that is inherently dynamic such as the operation of a system or process, it is often necessary to create a partially or fully-functional simulation of that process. Commercial aviation and military pilot training has long understood the importance of simulation in helping future and current pilots learn and retain their flight skills. Although powerful authoring tools are becoming available, simulation courseware has typically been very expensive to develop because of the high degree of detail and code development that has been required. The amount of physical fidelity required by a simulation varies and is often less than one might expect. Also, simulations may be relatively directed or undirected (not allowing or promoting exploration and a wide range of interactions).

Application to Education and Training-Each type of courseware described above has its niche. For example, hypermedia has great instructional power. As noted above, the ability to associatively link information is the key to the thought process. Sensory perceived information has traditionally been recorded in a linear fashion, such as sequential frame after frame, and music note after note. The human brain, however, has the ability to search knowledge and experience memories to connect directly and indirectly related information into new patterns.

One hypermedia application starts with showing a graphic of an automobile engine. Unseen behind the graphic are several areas, called "buttons," which allow the user to choose a part of the engine to investigate. If the student selects the exhaust area of the graphic, another screen appears with a close-up of the exhaust system. Selection of the intake manifold brings up a video clip of the operation of the carburetor, or the brakes, or the power steering system, or any related areas which the student chooses to pursue. 
There are many education and training applications of each type of courseware discussed ranging from tutorials to simulations. The following sample references include examples of the various types of courseware applications ${ }^{3}$ :

- CBT-Developing Technical Training: A Structured Approach for the Development of Classroom- and Computer-Based Instructional Materials (Clark, 1989). Making CBT Happen (Gery, 1987). Instructional Designs for Microcomputer Courseware (Jonassen, 1988).

- EPSS-Electronic Performance Support Systems (Gery, 1992).

- Simulation-Simulation Fidelity in Training System Design: Bridging the Gap Between Reality and Training (Hays and Singer, 1989).

- Hypertext-Designing Structured Hypertext and Structured Access to Hypertext (Jonassen, 1988).

- ITS-Artificial Intelligence and Education (Lawler and Yazdami, 1987).

Strengths and Limitations. The following tables illustrate the strengths and limitations of hypermedia. Note that each type of courseware presented above has its own set of strengths and limitations. Many of these can be extrapolated from the taxonomy presented in the next subtopic of this report.

Table 14. Strengths of courseware applications.

\begin{tabular}{|c|c|}
\hline $\begin{array}{l}\text { Hypermedia is relatively } \\
\text { inexpensive }\end{array}$ & $\begin{array}{l}\text { In comparison with comparable computer software, } \\
\text { hypermedia programs are inexpensive ( } \$ 100 \text { to } \$ 300) \text {, with } \\
\text { discounts for educators and learners. In many cases, the } \\
\text { price includes the rights to distribute created programs. }\end{array}$ \\
\hline $\begin{array}{l}\text { Hypermedia is relatively easy } \\
\text { to learn }\end{array}$ & $\begin{array}{l}\text { Sophisticated hypermedia programs can be created with } \\
\text { fields, buttons, and graphic objects, without requiring the } \\
\text { scripting component. With only a few hours invested, most } \\
\text { users can create lessons and presentations. }\end{array}$ \\
\hline $\begin{array}{l}\text { Hypermedia presentations are } \\
\text { easy to store }\end{array}$ & $\begin{array}{l}\text { Computer-based slide shows created with hypermedia are } \\
\text { easy to store and modify. }\end{array}$ \\
\hline $\begin{array}{l}\text { Multimedia links are } \\
\text { supported }\end{array}$ & $\begin{array}{l}\text { Hypermedia programs offer easy links to graphics, sound } \\
\text { video, and CD-ROM. }\end{array}$ \\
\hline
\end{tabular}

\footnotetext{
${ }^{3}$ See the bibliography of this study for an extensive listing of books and articles relating to courseware applications.
} 
Table 14. Strengths of courseware applications.

\begin{tabular}{|c|c|}
\hline $\begin{array}{l}\text { Hypermedia can be } \\
\text { motivational }\end{array}$ & $\begin{array}{l}\text { Instructors have the power to create motivational, interactive } \\
\text { programs. }\end{array}$ \\
\hline Exploration and association & $\begin{array}{l}\text { Hypermedia applications allow users to build their own } \\
\text { associations between bits of information, based on their } \\
\text { interests. Well-designed hypermedia programs can both } \\
\text { motivate and assist learners to explore a topic. }\end{array}$ \\
\hline $\mathrm{CMI}$ and $\mathrm{CAT}$ can save time & $\begin{array}{l}\text { Can reduce the amount of time required by students to go } \\
\text { through a course by branching around previously learned } \\
\text { material. }\end{array}$ \\
\hline $\begin{array}{l}\text { CMI can reduce } \\
\text { administrative costs }\end{array}$ & $\begin{array}{l}\text { With the computer managing the recordkeeping, fewer } \\
\text { administrative staff may be required. }\end{array}$ \\
\hline Mastery-based & $\begin{array}{l}\text { CBT can provide the right amount of practice to the student } \\
\text { by enforcing mastery requirements. Some learners need lots } \\
\text { of examples and practice to learn a new concept or fact while } \\
\text { others may need very little. }\end{array}$ \\
\hline Psychologically sound & $\begin{array}{l}\text { ITSs can often help diagnose the precise cognitive errors that } \\
\text { learners are having and help them address these problems } \\
\text { directly. }\end{array}$ \\
\hline Safety & $\begin{array}{l}\text { Dry-lab simulations are often much safer than wet-labs, } \\
\text { especially when combustibles, explosives or radiative } \\
\text { materials are being simulated. }\end{array}$ \\
\hline Multiple viewpoints & $\begin{array}{l}\text { Advanced CBT (and multimedia) can present the same } \\
\text { content from several viewpoints enabling students to grasp } \\
\text { more fully the new material. }\end{array}$ \\
\hline Cost-effectiveness & $\begin{array}{l}\text { Most courseware applications can reduce learning time and } \\
\text { improve retention and transfer of training over traditional } \\
\text { classroom lectures. }\end{array}$ \\
\hline
\end{tabular}


Table 15. Limitations of courseware applications.

\begin{tabular}{|c|c|}
\hline Y19 & क्ञाव \\
\hline Disorder & $\begin{array}{l}\text { Poorly-designed hypermedia and other programs can easily } \\
\text { turn into hyperchaos, where the user has too many choices } \\
\text { and gets lost. Research is continuing to determine the } \\
\text { optimal number of selections per screen and the best methods } \\
\text { to promote learning in a hypermedia environment. }\end{array}$ \\
\hline $\begin{array}{l}\text { Complex to learn at scripting } \\
\text { level }\end{array}$ & $\begin{array}{l}\text { Although the object level (buttons, fields, etc.) is relatively } \\
\text { easy to learn, novices can quickly get lost and frustrated with } \\
\text { scripting languages. }\end{array}$ \\
\hline Difficult to project & $\begin{array}{l}\text { One of the applications for hypermedia is to create } \\
\text { interactive, dynamic computer slide shows. The problem is } \\
\text { that many schools do not have the equipment to project the } \\
\text { shows for presentations. }\end{array}$ \\
\hline $\begin{array}{l}\text { High level of expertise } \\
\text { required for development or } \\
\text { customization }\end{array}$ & $\begin{array}{l}\text { Many courseware applications are very complex and require } \\
\text { a high level of expertise to develop or customize. Special } \\
\text { authoring tools are required to create the courseware. }\end{array}$ \\
\hline Costs & $\begin{array}{l}\text { Cost of development of the more advanced courseware } \\
\text { application options can be high. }\end{array}$ \\
\hline Testing & $\begin{array}{l}\text { The more complex the courseware, the more testing and } \\
\text { validation/verification is required. It becomes very much like } \\
\text { software in this regard. }\end{array}$ \\
\hline Unmanageable & $\begin{array}{l}\text { Without teacher-support, students can become overwhelmed } \\
\text { and discouraged rather easily. }\end{array}$ \\
\hline Platform-specific & $\begin{array}{l}\text { Most courseware applications are generally restricted to one } \\
\text { platform. If you create a slide show with the ToolBook } \\
\text { authoring system, it will require an IBM computer with } \\
\text { Microsoft Windows to run the program. }\end{array}$ \\
\hline Delivery fees and files & $\begin{array}{l}\text { In some cases, a developer may be required to pay a } \\
\text { publication fee for delivery of an application. In other cases, } \\
\text { the delivery files are free, but may be extremely large, making } \\
\text { them difficult to distribute on floppy diskettes. }\end{array}$ \\
\hline
\end{tabular}




\section{Subtopic 1.3 A Multimedia Taxonomy: A Guide to Understanding Essential Differences}

\section{What taxonomies are available to help differentiate the many types of multimedia-related technologies?}

One of the major impediments to the adoption of advanced training technology is the inappropriate comparison of the costs and benefits of various types of courseware at different levels of sophistication. Well-meaning individuals are often caught between options and have no clear way of discriminating what they need and what that should cost. The diversity of multimedia and courseware applications is enormous, ranging from simple hyper-text linked documentation to complete interactive simulations. Each application will take on the generic title "advanced technology" or "multimedia" to increase its sales appeal, but there can be vast differences. While it is not hard to distinguish between the two extremes, it can be difficult to define and label applications that fall somewhere in between.

To help understand the various dimensions and their impact on development time and cost, perhaps the best system is one proposed by Vince Eugenio and Eileen Habelow of AT\&T. Their approach identifies four primary "types" (or levels of sophistication) of multimedia products. These types are like guideposts on the steeply inclined multimedia trail, with the first guidepost at 0 (including applications that are barely sophisticated enough to be called multimedia) at the foot of the trail, and the last, and most sophisticated, at 3 (including applications such as nondirected simulators) currently at the "summit." As should be expected, the price tag for development and implementation increases dramatically from type 0 to 3 , as does the degree to which SAT processes are required. While a type 0 application may require less than 100 development hours per hour of instruction delivered, type 3 may average between 400 and 800 hours (and often more).

Understanding the implications of the continuum is extremely important in planning to use advanced technology. Without this knowledge it is easy to make inappropriate comparisons that can lead to building or purchasing applications that are inadequate (don't match the required skills, knowledge and conditions) or, at the other extreme, that are too capable and costs more than needed.

This system appears to be so useful that the entire set of three matrices is included below. The columns of the matrices are the multimedia type $(0$ to 3$)$. The rows are specific attributes relating to:

1) Type Definitions: includes purpose, instructional goals, product examples, and features;

2) Resource Requirements: includes personnel skill sets, hardware and software, and development time estimates; 
3) Type Characteristics: includes levels of interactivity, sophistication of simulations, user controls, interfaces, and media elements.

To assist in interpreting the matrix, a summary of the essential elements of each type of multimedia is provided below:

Type 0, hypertext and hypermedia applications:

Hyperlinked, electronic access to information. Branching and search capabilities. Used primarily for information dissemination.

Type I, interactive hypertext and hypermedia applications:

Hyperlinked, instructional presentations with text-based explanations enhanced with simple graphics and/or sound. Primarily for knowledge-based training/objectives. Simple trainee interface.

\section{Type II, interactive multimedia:}

Hyperlinked or sequential instruction which uses multimedia elements such as graphics, video, animation, and sound. Primarily for performance-based training and complex intellectual tasks. Provides situational and task simulations and allows for practice. (No interactions with simulated physical equipment.) Sophisticated trainee interface.

\section{Type III, interactive multimedia}

Hyperlinked or sequential instruction which makes full use of advanced video, animation/modeling, sound, and graphics. Allows student to interact with simulated physical equipment within the context of performing a job.

In the past, levels of interactive video disc (I, $I$, and III) were defined by the computer's ability to access frames on a video disc. It is the goal of this multimedia types matrix to take the focus from levels of platform ability, to types of multimedia products. As reflected in the multimedia types matrix, the essential differences among types lie in the quantity and sophistication of the media elements, and in the programming complexity which ultimately drives product development hours. This matrix defines' "types" of multimedia according to the sophistication of instructional design and media elements (based on the requirements of the application objectives). 
Table 16. Multimedia types matrix: Definitions.

\begin{tabular}{|c|c|c|c|c|}
\hline $\begin{array}{c}\text { Common } \\
\text { Name }\end{array}$ & $\begin{array}{l}\text { Aypertext/ } \\
\text { Eypermedia }\end{array}$ & $\begin{array}{l}\text { Interactive } \\
\text { Hypertext/ } \\
\text { Hypermedia }\end{array}$ & $\begin{array}{l}\text { Interactive } \\
\text { Multimedia }\end{array}$ & $\begin{array}{l}\text { Interactive } \\
\text { Multimedia }\end{array}$ \\
\hline $\begin{array}{c}\text { Goal of } \\
\text { Application }\end{array}$ & $\begin{array}{l}\text { Electronic access of } \\
\text { information; Information } \\
\text { Dissemination. }\end{array}$ & $\begin{array}{l}\text { Mastery of knowledge } \\
\text { based on simple procedural } \\
\text { objectives. }\end{array}$ & $\begin{array}{l}\text { Performance-based training } \\
\text { of complex intellectual } \\
\text { tasks. }\end{array}$ & $\begin{array}{l}\text { Performance-based } \\
\text { training of complex } \\
\text { intellectual and simulated } \\
\text { physical tasks. }\end{array}$ \\
\hline $\begin{array}{l}\text { Instructional } \\
\text { Goals }\end{array}$ & $\begin{array}{l}\text { Leamer will be able to } \\
\text { access information for job } \\
\text { task performance or } \\
\text { reference. }\end{array}$ & $\begin{array}{l}\text { Leamer will be able to } \\
\text { define, identify, list, matsh, } \\
\text { recall, select, recognize, } \\
\text { generalize, state, calculate, } \\
\text { complete, select, compili, } \\
\text { describe, summarize, } \\
\text { paraphrase, detect, } \\
\text { differentiate, distinguish, } \\
\text { and observe. }\end{array}$ & $\begin{array}{l}\text { Same as Type I. In } \\
\text { addition: learner will be } \\
\text { able to apply, troubleshoot, } \\
\text { diagnose, breakdown, } \\
\text { solve, translate, analyze, } \\
\text { explain, plan, prescribe, } \\
\text { revise, transform, appraise, } \\
\text { assess, critique, interpret, } \\
\text { judge, rate, support, } \\
\text { observe, evaluate, and test. }\end{array}$ & $\begin{array}{l}\text { Same as Type II. In } \\
\text { addition: leamer will be } \\
\text { able to calibrate, measure, } \\
\text { adjust, operate, connect, } \\
\text { attach, remove, install, } \\
\text { disconnect, patch, startup, } \\
\text { turnoff, check, inspect, } \\
\text { rotate, tum, open, close, } \\
\text { assemble, disassemble, } \\
\text { experience, touch, move, } \\
\text { ask, converse, listen, and } \\
\text { record. }\end{array}$ \\
\hline $\begin{array}{l}\text { Instructional } \\
\text { Design }\end{array}$ & $\begin{array}{l}\text { Primary focus is principles } \\
\text { of content analysis, } \\
\text { organization, and message } \\
\text { design. }\end{array}$ & $\begin{array}{l}\text { Primary focus is content } \\
\text { and simple task analysis. } \\
\text { Requires drill and practice } \\
\text { approach with repetition } \\
\text { and feedback. Also, a } \\
\text { systematic approach to } \\
\text { instructional design (i.e., } \\
\text { Instructional System } \\
\text { Design-type model) in } \\
\text { addition to message design } \\
\text { principles. }\end{array}$ & $\begin{array}{l}\text { Primary focus is task } \\
\text { analysis, also requires } \\
\text { content analysis of } \\
\text { prerequisite information } \\
\text { required for performance. A } \\
\text { prescriptive-diagnostic } \\
\text { approach to task } \\
\text { performance with rich } \\
\text { remediation exercises based } \\
\text { on task performance. Strict } \\
\text { adherence to a systematic } \\
\text { approach to instructional } \\
\text { design is required to create } \\
\text { a very detailed design } \\
\text { document. Simulation } \\
\text { design (i.e., task practice } \\
\text { with complex feedback and } \\
\text { system mimic) increases } \\
\text { complexity of the } \\
\text { instructional design. }\end{array}$ & $\begin{array}{l}\text { Primary focus is task } \\
\text { analysis; also requires } \\
\text { content analysis of } \\
\text { prerequisite information } \\
\text { required for performance. } \\
\text { A preseriptive-diagnostic } \\
\text { approach to task } \\
\text { performance with rich } \\
\text { remediation exercises } \\
\text { based on task performance. } \\
\text { Strict adherence to a } \\
\text { systematic approach to } \\
\text { instructional design is } \\
\text { required to create a very } \\
\text { detailed design document } \\
\text { Simulation design (i.e., } \\
\text { task practice with complex } \\
\text { feedback and system } \\
\text { mimic) increases } \\
\text { complexity of the } \\
\text { instructional design. The } \\
\text { design of a physical system } \\
\text { (e.g., flight simulator) } \\
\text { requires very sophisticated } \\
\text { design specifications. }\end{array}$ \\
\hline
\end{tabular}


Table 17. Multimedia types matrix: Resource requirements.

\begin{tabular}{|c|c|c|c|c|}
\hline $\begin{array}{l}\text { Common } \\
\text { Name }\end{array}$ & $\begin{array}{l}\text { Hypertext/ } \\
\text { Hypermedia }\end{array}$ & $\begin{array}{l}\text { Interactive } \\
\text { Hypertext/ } \\
\text { Hypermedia }\end{array}$ & $\begin{array}{l}\text { Interactive } \\
\text { Multimedia }\end{array}$ & $\begin{array}{l}\text { Interactive } \\
\text { Multimedia }\end{array}$ \\
\hline $\begin{array}{c}\text { Sample } \\
\text { Applications }\end{array}$ & $\begin{array}{l}\text { On-line help for Windows } \\
\text { and Windows Applications. }\end{array}$ & $\begin{array}{l}\text { Informational overviews, } \\
\text { Fundamental courses. }\end{array}$ & $\begin{array}{l}\text { Technical or computer } \\
\text { systems training. }\end{array}$ & $\begin{array}{l}\text { Equipment or mechanical } \\
\text { repair simulators, military } \\
\text { weapons simulators. }\end{array}$ \\
\hline Applications & $\begin{array}{l}\text { Documentation and job aids } \\
\text { stored electronically. } \\
\text { Hyperlinked documents } \\
\text { with electronic bookmarks, } \\
\text { dictionary, glossary, index, } \\
\text { annotations, and search } \\
\text { capabilities. May } \\
\text { incorporate simple graphics. }\end{array}$ & $\begin{array}{l}\text { A hyperlinked instructional } \\
\text { presentation using text- } \\
\text { based explanations } \\
\text { enhanced with simple } \\
\text { graphics. Presents } \\
\text { information and } \\
\text { instructional explanations. }\end{array}$ & $\begin{array}{l}\text { A hyperlinked or sequential } \\
\text { instructional presentation } \\
\text { which may use multimedia } \\
\text { elements such as narration, } \\
\text { graphics, video, and/or } \\
\text { simple animations. Explains } \\
\text { and demonstrates how to } \\
\text { perform a task and allows } \\
\text { the student to practice the } \\
\text { task. There is no interaction } \\
\text { with simulated physical } \\
\text { equipment. }\end{array}$ & $\begin{array}{l}\text { A hyperlinked or } \\
\text { sequential instructional } \\
\text { presentation using } \\
\text { multimedia elements such } \\
\text { as advanced graphics, } \\
\text { animation, sound cffects, } \\
\text { narration, and video. } \\
\text { Allows student to practice } \\
\text { tasks with simulated } \\
\text { physical equipment or job } \\
\text { environments. }\end{array}$ \\
\hline $\begin{array}{l}\text { Required } \\
\text { Skills Set }\end{array}$ & $\begin{array}{l}\text { Working knowledge of } \\
\text { hypertext/hypermedia } \\
\text { design and development } \\
\text { tools. }\end{array}$ & $\begin{array}{l}\text { Working knowledge of } \\
\text { instructional design, } \\
\text { instructional technology, } \\
\text { hypermedia design, } \\
\text { storyboarding, and } \\
\text { hypermedia and multimedia } \\
\text { authoring tools. }\end{array}$ & $\begin{array}{l}\text { Working knowiedge of } \\
\text { instructional design, } \\
\text { instructional technology, } \\
\text { project management, and } \\
\text { most of the following: } \\
\text { multimedia authoring tools, } \\
\text { graphics creation, sound } \\
\text { editing, narration } \\
\text { techniques, multimedia } \\
\text { storyboarding, and audio. } \\
\text { video, and photographic } \\
\text { production techniques. }\end{array}$ & $\begin{array}{l}\text { Working knowledge of } \\
\text { instructional design, } \\
\text { instructional technology, } \\
\text { project management, } \\
\text { multimedia authoring } \\
\text { tools, programming } \\
\text { principles, graphics } \\
\text { creation, sound editing, } \\
\text { narration techniques, } \\
\text { multimedia storyboarding, } \\
\text { audio, video, and } \\
\text { photographic production } \\
\text { techniques. }\end{array}$ \\
\hline $\begin{array}{l}\text { Specialized } \\
\text { Hardware and } \\
\text { Software }\end{array}$ & $\begin{array}{l}\text { DOS, MAC, MPC, or } \\
\text { UNIX computer, hypertext } \\
\text { authoring package. }\end{array}$ & $\begin{array}{l}\text { DOS, MAC, MPC, or } \\
\text { UNDX computer with } \\
\text { suitable hard drive; } \\
\text { authoring system. }\end{array}$ & $\begin{array}{l}\text { Windows MPC, MAC, or } \\
\text { muitimedia capable UNIXX } \\
\text { computer with large hard } \\
\text { drive; multimedia authoring } \\
\text { tools, hardware and } \\
\text { software for audio, } \\
\text { photographic, and video } \\
\text { production and editing (if } \\
\text { sound, photos, or video is } \\
\text { used.) }\end{array}$ & $\begin{array}{l}\text { Windows MPC. MAC or } \\
\text { Multimedia capable UNIX } \\
\text { computer with large hard } \\
\text { drive; multimedia } \\
\text { authoring tools; hardware } \\
\text { and software for audio, } \\
\text { photographic, and video } \\
\text { production and editing. }\end{array}$ \\
\hline $\begin{array}{l}\text { Development } \\
\text { Ratios } \\
\text { (Development } \\
\text { to one hour } \\
\text { delivery) }\end{array}$ & Less than 100 hours & 100 to 300 hours & 200 to 500 hours & 400 to 800 hours \\
\hline
\end{tabular}


Table 18. Multimedia types matrix: Characteristics.

\begin{tabular}{|c|c|c|c|c|}
\hline & Type 0 & Type I & Type II & Type III \\
\hline $\begin{array}{l}\text { Common } \\
\text { Name }\end{array}$ & $\begin{array}{c}\text { Hypertext/ } \\
\text { Hypermedia }\end{array}$ & $\begin{array}{c}\text { Interactive } \\
\text { Hypertext/ } \\
\text { Hypermedia }\end{array}$ & $\begin{array}{l}\text { Interactive } \\
\text { Multimedia }\end{array}$ & $\begin{array}{l}\text { Interactive } \\
\text { Multimedia }\end{array}$ \\
\hline Interactivity & $\begin{array}{l}\text { Hyperlinked } \\
\text { documentation; simple } \\
\text { graphics optional; user has } \\
\text { easy access to different } \\
\text { layers of information. }\end{array}$ & $\begin{array}{l}\text { User response to system } \\
\text { prompts; simple branching, } \\
\text { feedback and remediation. }\end{array}$ & $\begin{array}{l}\text { High interactivity, user is } \\
\text { actively involved in } \\
\text { answering questions, } \\
\text { responding to system and } \\
\text { situational simulations, } \\
\text { solving problems and } \\
\text { making decisions, rich } \\
\text { branching, feedback and } \\
\text { remediation; presentation } \\
\text { sequences may be based on } \\
\text { user performance. }\end{array}$ & $\begin{array}{l}\text { High interactivity; user is } \\
\text { actively involved in } \\
\text { answering questions; } \\
\text { responding to system, } \\
\text { situational, and physical } \\
\text { simulations, solving } \\
\text { problems and making } \\
\text { decisions, rich branching, } \\
\text { feedback, and remediation; } \\
\text { presentation sequences } \\
\text { may be based on user } \\
\text { performance. }\end{array}$ \\
\hline Simulations & No Simulations. & No Simulations. & $\begin{array}{l}\text { Directed simulations which } \\
\text { are functionally restricted } \\
\text { (only specific parts of the } \\
\text { system are modeled) and } \\
\text { reflect only the necessary } \\
\text { instructional objectives; } \\
\text { simulations which place the } \\
\text { leamer in a situation where } \\
\text { decisions must be made. }\end{array}$ & $\begin{array}{l}\text { Uses a combination of } \\
\text { situational, directed and } \\
\text { non-directed simulations. } \\
\text { In a non-directed } \\
\text { simulation, the entire } \\
\text { system is modeled to } \\
\text { mimic the functionality of } \\
\text { the actual system. }\end{array}$ \\
\hline $\begin{array}{c}\text { User } \\
\text { Controls and } \\
\text { Interface }\end{array}$ & $\begin{array}{l}\text { Hypertext linking: topic } \\
\text { search, word search, } \\
\text { browse capabilities, icon } \\
\text { driven cueing. Additionally, } \\
\text { imbedded functions such as } \\
\text { hypertext documentation, } \\
\text { user status and reporting, } \\
\text { and system help. }\end{array}$ & $\begin{array}{l}\text { Simple user interface } \\
\text { providing basic presentation } \\
\text { controls such as quit, pagre } \\
\text { forward and back, play, } \\
\text { pause, resume, and repeat. } \\
\text { Additionally, imbedded } \\
\text { functions such as hypertext } \\
\text { documentation, user status } \\
\text { and reporting, and systern } \\
\text { help. }\end{array}$ & $\begin{array}{l}\text { Sophisticated user interface } \\
\text { providing basic presentation } \\
\text { controls such as quit, page } \\
\text { forward and back, play, } \\
\text { pause, resume, and repeat. } \\
\text { Additionally, imbedded } \\
\text { functions such as hypertext } \\
\text { documentation, user status } \\
\text { and reporting, and system } \\
\text { help. }\end{array}$ & $\begin{array}{l}\text { Sophisticated user } \\
\text { interface providing basic } \\
\text { presentation controls such } \\
\text { as quit, page forward and } \\
\text { back; play, pause, resume, } \\
\text { and repeat. Additionally, } \\
\text { imbedded functions such } \\
\text { as hypertext } \\
\text { documentation, user status } \\
\text { and reporting, and system } \\
\text { help. }\end{array}$ \\
\hline $\begin{array}{l}\text { Media } \\
\text { Elements }\end{array}$ & $\begin{array}{l}\text { Text and low level graphics } \\
\text { and audio. }\end{array}$ & $\begin{array}{l}\text { Non-professional narration; } \\
\text { purchased sound effects } \\
\text { and music clips; un- } \\
\text { retouched 8-bit low color } \\
\text { photos; clip art, flow charts } \\
\text { and line drawings, no 2-D } \\
\text { or 3-D models; no video. }\end{array}$ & $\begin{array}{l}\text { Professional or non- } \\
\text { professional narration; } \\
\text { purchased or custom sound } \\
\text { effects and music; video; } \\
\text { minimally retouched 16-bit } \\
\text { medium color photos; } \\
\text { simple 2-D animation; } \\
\text { graphics; simple 3-D } \\
\text { models. }\end{array}$ & $\begin{array}{l}\text { Professional or non- } \\
\text { professional narration; } \\
\text { purchased or custom } \\
\text { sound effects and music; } \\
\text { video; graphics; complex } \\
\text { 24-bit high color photo } \\
\text { enhancement, composition } \\
\text { and manipulation; complex } \\
\text { 2-D and 3-D animation; } \\
\text { model building, and } \\
\text { rendering, complex } \\
\text { content specific graphics. }\end{array}$ \\
\hline
\end{tabular}




\title{
Subtopic 1.4 Logistic and Organizational Implications of the Various Forms of ATT
}

\author{
What logistic implications do these technologies have? What kinds of organizational or \\ training facility configurations may be required?
}

In addition to the strengths and limitations presented in Subtopic 1.2 above, each of the technologies has implications in terms of acquisitions, developing instruction, delivery of instruction, and organizing for their most effective use. Because of high development and acquisition costs, some technologies are best supported as part of a consortium. Some technologies may require specialized facilities, while others are amenable to being distributed to the individual workstation.

\section{Multimedia}

Multimedia Acquisition Options-First, note that a major shift is currently taking place from IVD to CD-ROM. ${ }^{4}$ For the next few years, availability of multimedia courseware will lag behind availability of hardware. To develop an entire curricula for multimedia is a daunting task (as noted in the multimedia types subtopic above, multimedia development can be labor intensive and expensive). Three options are described in Table 19.

\footnotetext{
4 Most new computers are being sold as multimedia machines with CD-ROMs having at least double-spin capacity, sound cards, and sufficient memory and processing power to support the MPC-2 standard. Unfortunately, upgrading older machines is problematic. Currently the number of courses available on CD-ROM is expanding rapidly as this medium is becoming more widely adopted. Many courseware developers are moving IVD courses to CD-ROM and almost all new multimedia development is in CDROM. Only a year or two ago, the selection greatly favored IVD, and yet, within a couple of years it will be almost impossible even to purchase an IVD player.
} 
Table 19. Multimedia acquisition options.

\begin{tabular}{|c|c|}
\hline 6) & L \\
\hline 1 & $\begin{array}{l}\text { Purchase (and customize) existing multimedia courseware } \\
\text { First, because CD-ROM is entirely digital, many instructional development } \\
\text { companies are finding it profitable to produce a baseline version of a generic course, } \\
\text { then allow customers to modify and/or expand that baseline. The cost of customizing } \\
\text { generic courses can be significantly lower than creating the same courses from the } \\
\text { beginning. }\end{array}$ \\
\hline 2 & $\begin{array}{l}\text { Develop consortium to syndicate the costs } \\
\text { Many organizations are banding together to afford the cost of developing new } \\
\text { multimedia products. With a unified set of products in hand, a consortium is then } \\
\text { able to attract sizeable market shares and quickly recoup most, if not all, of the costs } \\
\text { and possibly make a profit. When the consortium selects a curriculum and standard } \\
\text { user interface format and tool-set, it is able to ensure much shorter development time } \\
\text { across all the members of the consortium than if one organization were to attempt } \\
\text { the entire project. Not only is the risk considerably less for each team member but } \\
\text { the benefits (free use of all consortium-produced courseware) are far greater. }\end{array}$ \\
\hline 3 & $\begin{array}{l}\text { Build your own } \\
\text { With the shift to digital technologies, it is now possible for a small company to build } \\
\text { reasonably high-quality multimedia courseware in its "garage." From the initial } \\
\text { authoring, to adding in digital video and sound clips, to mastering and sending away } \\
\text { for mass production, the process is becoming better and better supported by } \\
\text { relatively inexpensive hardware and powerful software editing and authoring tools. } \\
\text { There is a steep learning curve, however, and the standards and technology are } \\
\text { changing rapidly-thus while it is now feasible, it is not for the faint-hearted. Also, } \\
\text { note that all of the principles of design that result in good instruction still apply to } \\
\text { multimedia development but there is the added cost of production as well. As in } \\
\text { Subtopic } 1.3 \text {, not all multimedia are created equal. The amount of design and effort } \\
\text { needed to produce a hypertext CD-ROM is significantly less than that required to } \\
\text { produce a non-directed simulation with high-fidelity sound and video. }\end{array}$ \\
\hline
\end{tabular}


Multimedia Facility Options-Several multimedia facility-related options appear to have merit in specific circumstances and are described in Table 20 below.

Table 20. Multimedia facility options.

\begin{tabular}{|c|c|}
\hline jion & 79 \\
\hline 1 & $\begin{array}{l}\text { Consolidate multimedia machines and support into large centers } \\
\text { The advantage of this approach is that the necessary technical support is always on } \\
\text { hand to get the hardware and courseware working correctly; tutoring and } \\
\text { proctoring for the courses and exams can be handled efficiently and expertly } \\
\text { (security is much less of a problem); use of the equipment can be scheduled } \\
\text { to maximize return on investment and to ensure that mandatory training } \\
\text { requirements have been met; and the number of machines and courseware packages } \\
\text { can be minimized. } \\
\text { A limitation of this option is that access to the equipment and courseware is less } \\
\text { convenient. It may require travel for the learner, the facility has to be scheduled } \\
\text { and may not be available at a time when learning is really needed or desired (this } \\
\text { option is not conducive to "just-in-time" training), and a center may become } \\
\text { unnecessary as multimedia machines become more widely available. } \\
\text { This option was much more important in the days of very expensive and finicky } \\
\text { multimedia workstations. Networking in the center also supported efficient CBT } \\
\text { that could be operated from a shared disk. Printing and recordkeeping could be } \\
\text { managed centrally, as well. The older IVD workstations cost two to three times } \\
\text { more and were far more subject to mechanical, electronic, and configuration- } \\
\text { caused failures than today's CD-ROM workstations. Therefore technical support } \\
\text { was absolutely critical. But with promised improvements to graphical software } \\
\text { operating systems, many of the current configuration problems may also disappear. } \\
\text { Dedicated facilities may still be needed when the multimedia is of Type II as } \\
\text { discussed in Subtopic 1.3, and the multimedia or Computer Based Instruction is } \\
\text { tied to physical mockups. }\end{array}$ \\
\hline
\end{tabular}


Table 20. Multimedia facility options.

\begin{tabular}{|c|c|}
\hline 2 & $\begin{array}{l}\text { Create many small centers or have one or two special purpose machines } \\
\text { distributed at many locations } \\
\text { This option dramatically improves convenience but offers less in terms of } \\
\text { scheduling, tracking, security, tutoring, and technical support. Utilization rates } \\
\text { may be somewhat lower at first than when large centers are carefully scheduled, } \\
\text { but when learners come to recognize the convenience and knowledge readily } \\
\text { available to them the problem may then become one of periods of too much } \\
\text { demand. Courseware may be circulated as needed to remote centers/workstations. } \\
\text { Given sufficient legal rights, it may be possible to even circulate the courseware to } \\
\text { individuals to take home and use on their own home multimedia machines, } \\
\text { allowing for the sharing of training costs (for the learner's time) between } \\
\text { organization and employee. }\end{array}$ \\
\hline 3 & $\begin{array}{l}\text { Anticipate "universal" multimedia capability } \\
\text { As more and more antiquated machines are discarded and network and multimedia- } \\
\text { capable machines take their place, it may not be necessary to create centers or even } \\
\text { dedicate many machines for multimedia training. As with the telephone, soon most } \\
\text { workers may have machines that could access the training at their workstations. } \\
\text { Distribution of the courseware could be handled in the same way as company } \\
\text { procedure manuals. Eventually even CD-ROMs may become unneeded as } \\
\text { courseware will be run interactively over high-speed networks. This is not } \\
\text { currently feasible over existing IANs, WANs or the Internet because of the huge } \\
\text { volume of data used in multimedia and the need for immediate interactivity of } \\
\text { multimedia. However, it is feasible to copy multimegabyte files from the network } \\
\text { in a relatively short length of time, run these on local machines, and then enter test } \\
\text { and student progress results. } \\
\text { As progress is made in transmitting live digitized video and other binary data at } \\
\text { faster speeds and in greater volume, the current bounds of multimedia will expand } \\
\text { to include all kinds of realtime audio and video interactivity between individuals } \\
\text { and groups (classes). The current definitional divisions within ATT will blur and } \\
\text { combine into one huge system. }\end{array}$ \\
\hline
\end{tabular}




\section{Teleconferencing}

Table 21 below describes six viable options for teleconferencing operations. Each type of operation has important implications for organizational and facility design and logistics.

Table 21. Six viable options for teleconferencing operations.

\begin{tabular}{|c|c|}
\hline option: & Pी \\
\hline 1 & $\begin{array}{l}\text { Audio teleconferencing } \\
\text { Aside from equipment to be purchased (whether a single multidirectional } \\
\text { microphone is used or touch-to-talk mikes are placed in front of each participant) } \\
\text { and arrangements to be made with telephone personnel for availability of lines, } \\
\text { some consideration must be given to the acoustics of whatever room(s) will be } \\
\text { used for this kind of conferencing. Scheduling the conference is also an important } \\
\text { consideration, as with all types of conferencing. Course materials need to be } \\
\text { adapted for this use and all text, pictures and diagrams that need to be referenced } \\
\text { during the course must be distributed before the class. Most types of synchronous } \\
\text { distance learning work best when there is a facilitator/technician present at each } \\
\text { site. }\end{array}$ \\
\hline 2 & $\begin{array}{l}\text { Audio-graphic teleconferencing } \\
\text { This approach augments audioconferencing with an electronic blackboard that } \\
\text { allows the instructor to send video images to the students and, depending on the } \\
\text { system, for the students to send images to the instructor. Normal fax machines are } \\
\text { sometimes used to augment audio conferencing when more elaborate graphic } \\
\text { displays are not used. Software is emerging that allows several sites to co-edit } \\
\text { computer-based images that are displayed directly on computer monitors. }\end{array}$ \\
\hline 3 & $\begin{array}{l}\text { Land-based video conferencing } \\
\text { Many organizations have been using boardroom style video teleconferencing for } \\
\text { several years in conducting meetings and discussions. The quality of this type of } \\
\text { conferencing has been improving steadily as the prices have dropped. The use of } \\
\text { these capabilities for training is being explored by many organizations to reduce } \\
\text { travel costs. Far fewer sites may be involved than with satellite-based } \\
\text { teleconferencing, but these facilities can be set up at far greater convenience and } \\
\text { ease. If it is important for the instructor to see everyone or for two-way video to } \\
\text { be implemented, this approach may be more cost-effective than satellite-based } \\
\text { conferencing when the number of sites is small. Universities with special distance } \\
\text { learning networks have also been using repeaters rather than phone lines to } \\
\text { transmit courses to a limited number of classrooms. }\end{array}$ \\
\hline
\end{tabular}


Table 21. Six viable options for teleconferencing operations.

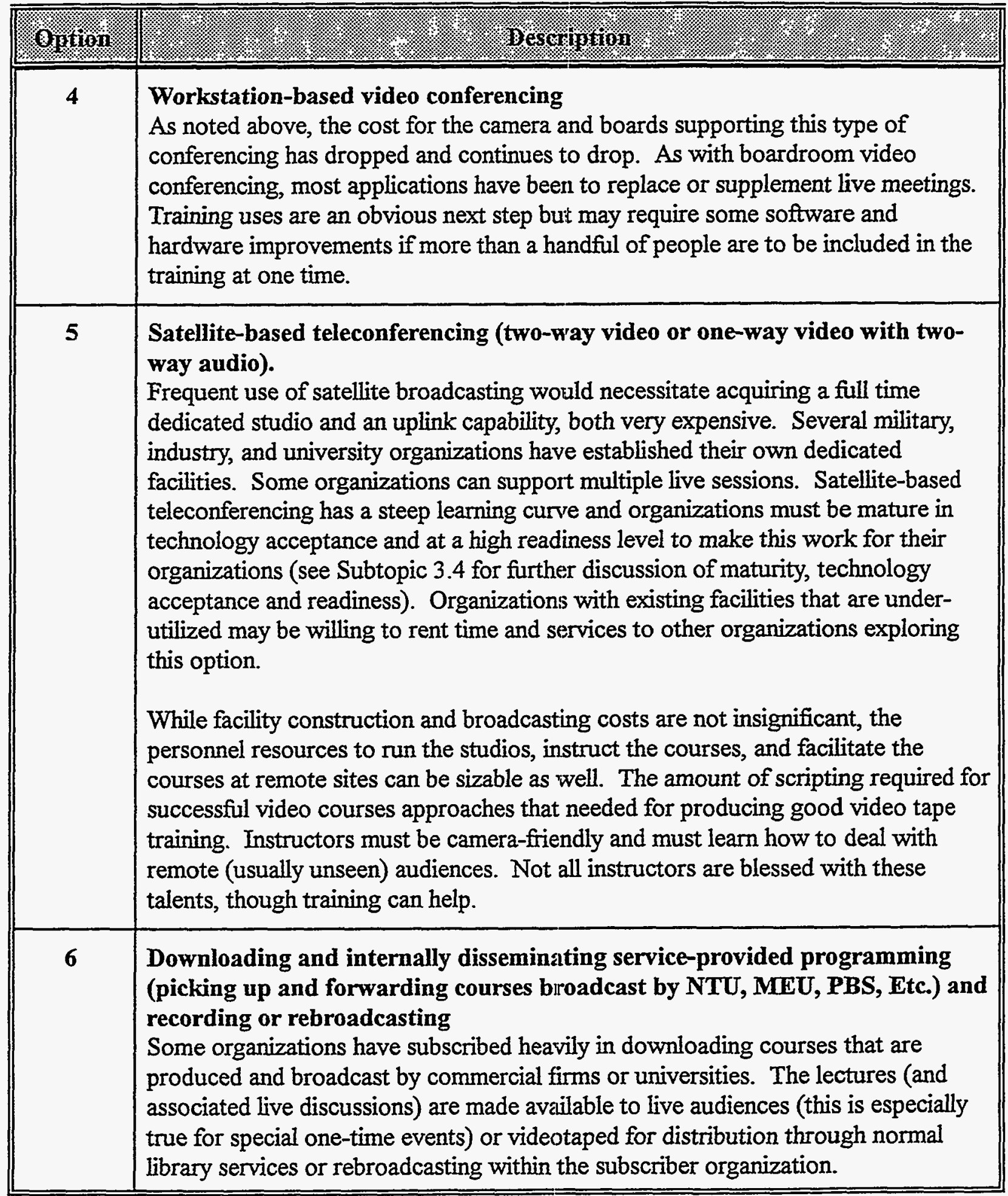




\section{Computer Networking}

The following table lists four of the most important computer networking operations options that are available.

Table 22. Operational options for computer networking.

\begin{tabular}{|c|c|}
\hline Opinio & (4: \\
\hline 1 & $\begin{array}{l}\text { Online information and e-mail-oriented help services } \\
\text { Making information available on the Internet through World Wide Web home } \\
\text { pages, Gopher Servers, or Anonymous FTP may make it possible for employees to } \\
\text { get information they need quickly enough that they may not need training, drill, or } \\
\text { practice on that information. Other network-based tools and databases, separate } \\
\text { from the Internet or inside an organization, may serve similar functions. This "just- } \\
\text { in-time" access to information will not preclude all training; but may help someone } \\
\text { who has learned a skill but not memorized the particulars get exactly what is } \\
\text { needed when it is needed. When information changes regularly, this may be better } \\
\text { than relying on training. Online tools have already started to expand beyond simple } \\
\text { information search and retrieval to case-based problem guidance and expert system } \\
\text { assistance and coaching. } \\
\text { Most organizations are already making information resource decisions that are } \\
\text { supportive of many of the basic information access capabilities described. The } \\
\text { more advanced are just now becoming available as electronic performance support } \\
\text { systems within the nation's most advanced companies. A less high-tech alternative } \\
\text { to providing online knowledge bases and expert systems is access through E-mail } \\
\text { to experts, instructors, and course administrators }\end{array}$ \\
\hline 2 & $\begin{array}{l}\text { E-mail tutoring and guidance added to existing exportable materials (e.g., } \\
\text { printed materials, and audio or video tape series) } \\
\text { Many universities are adding E-mail connections to their standard print-based } \\
\text { correspondence programs as well as live courses. Contacting individuals around } \\
\text { the world and nation is often easier than setting up an appointment with a college } \\
\text { professor. Instructors who have assisted learners through the years with the same } \\
\text { course work can have responses to choose from and customize as replies to } \\
\text { learners' questions. }\end{array}$ \\
\hline
\end{tabular}


Table 22. Operational options for computer networking.

\begin{tabular}{|c|l|}
\hline 3 & $\begin{array}{l}\text { Group-based discussions added to E-mail } \\
\text { Before the advent of the Internet, special computer conferencing software was } \\
\text { developed by DEC (VaxNotes), University of Michigan (Confer and its clone } \\
\text { Caucus), and others (e.g., PARTI). These programs supported group discussions } \\
\text { and are similar to those conducted on Compuserve. In many ways, some of these } \\
\text { products, though not as accessible as Internet Newsgroups, are superior because of } \\
\text { the way in which the topics and responses are organized and retrieved. As time } \\
\text { goes on, the types of group interaction possible on Internet will probably become } \\
\text { more varied, and these "threaded" and sensible group conversations will be more } \\
\text { available. Numerous organizations, including DOD and various universities, have } \\
\text { had excellent results conducting educational and training courses using computer } \\
\text { conferencing to support asynchronous classroom discussions. Earlier, this required } \\
\text { modem diahup connections. Now, with the Internet, E-mail or Newsgroup access, } \\
\text { this kind of communication is easier than ever, requiring very few organizational } \\
\text { changes. Other new groupware products such as Lotus Notes are also supporting } \\
\text { these kinds of group discussions. Perhaps the biggest impact, organizationally, is } \\
\text { the need to develop course moderators who can effectively teach courses } \\
\text { conducted online. Some conversion of curriculum will also be required to facilitate } \\
\text { these capabilities. }\end{array}$ \\
\hline 4 & $\begin{array}{l}\text { Fully integrated technology-supported learning } \\
\text { Various specialized classrooms have been developed to combine the best of } \\
\text { multimedia with networked computers and instructor-classroom interaction. In } \\
\text { these, each student desk is equipped with a computer. The instructor's podium has } \\
\text { controls for IVD, CD-ROM, VCR, overhead projectors, and several computer } \\
\text { sources, including all the students' computers and online networks. }\end{array}$ \\
\hline
\end{tabular}


Table 22. Operational options for computer networking.

\begin{tabular}{|c|c|}
\hline$\theta_{1}$ & l. \\
\hline 4 & 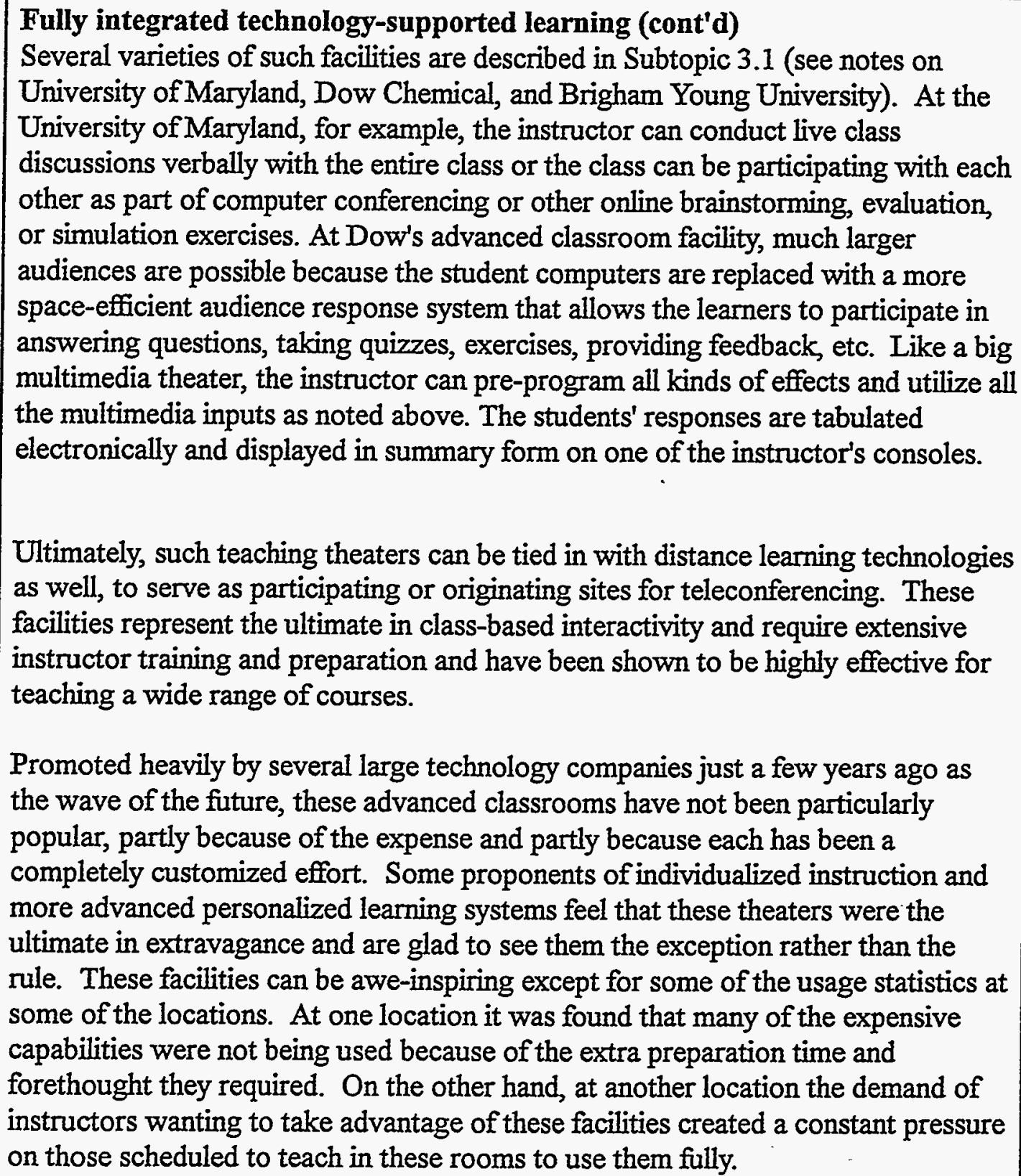 \\
\hline
\end{tabular}




\section{Courseware Applications}

The following table describes the logistics and organizational implications of the five important types of courseware applications.

Table 23. Organizational and logistical considerations of courseware application options.

\begin{tabular}{|c|c|}
\hline Ojarton & 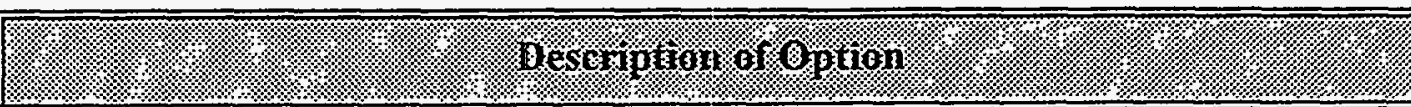 \\
\hline 1 & $\begin{array}{l}\text { Computer managed instruction (CMI) and computer adaptive testing (CAT) } \\
\text { Originally developed for the military, CMIl and CAT were administered in large } \\
\text { individualized study centers where learners could take written tests and have the } \\
\text { results scanned and scored and then printed out as prescriptions. Now, many CBT } \\
\text { packages come with a management and secure testing component, allowing the } \\
\text { testing and prescriptions to be done at a computer within the testing or learning } \\
\text { center. For security purposes, a facility may need proctors to monitor the learners } \\
\text { while taking the tests to ensure that notes are not used or answers copied down. } \\
\text { The latter problem has been somewhat alleviated by the creation of testing pools } \\
\text { from which items are randomly selected. If secure testing is not an important part } \\
\text { of the overall system, access to the management/prescription modules can be done } \\
\text { over networks and the need for a physical facility and proctors is eliminated. }\end{array}$ \\
\hline 2 & $\begin{array}{l}\text { Hypertext, presentations and computer-based training (CBT) } \\
\text { Just a few years ago CBT delivery tended to be done in learning centers (see } \\
\text { discussion above of the Multimedia options). Currently, depending on the capacity } \\
\text { of the learner's desktop computing equipment, it is often possible to take CBT } \\
\text { lessons at one's desk or at home. With continued networking of computers, the } \\
\text { lessons may not ever have to reside on the learner's computer, but be accessed via } \\
\text { the network. Group-based CBT is also possible, especially with video projection } \\
\text { or high intensity overhead projection using color LCD panels. Linear presentations } \\
\text { (slide shows) can be made very effectively using these tools. }\end{array}$ \\
\hline 3 & $\begin{array}{l}\text { Intelligent tutoring systems (ITS) } \\
\text { Until recently the capacity of the standard PC was not always adequate to run a } \\
\text { powerful ITS. Originally, special machines were required or high-powered } \\
\text { MicroVax or Sun Workstations. Now, with the increased power and with more } \\
\text { tools and graphical user interfaces, Windows is becoming a very acceptable } \\
\text { platform for ITS. The biggest drawback to ITS is the very high cost and high level } \\
\text { of expertise involved in creating it. }\end{array}$ \\
\hline
\end{tabular}


Table 23. Organizational and logistical considerations of courseware application options.

\begin{tabular}{|c|c|}
\hline Gintion & Q \\
\hline 4 & $\begin{array}{l}\text { Electronic performance support systems } \\
\text { These programs are ideally embedded into whatever computerized tools are } \\
\text { already present in the work environment where they are to be used. For the } \\
\text { manager who may need to travel and attend many meetings, a notebook, palm-top, } \\
\text { or personal digital assistant device may be the ideal platform. Some futurists } \\
\text { believe that standard PCs, as we know them, may disappear as more and more } \\
\text { smart tools with embedded training and functional software become available for } \\
\text { job-specific use. }\end{array}$ \\
\hline 5 & $\begin{array}{l}\text { Simulation } \\
\text { Simulation may impose significant facility requirements, often far more so than the } \\
\text { previous options. While some simulations may run on a desktop machine (e.g., } \\
\text { Microsoft Flight Simulator), others require powerful workstations, dedicated } \\
\text { facilities, and mockups. }\end{array}$ \\
\hline
\end{tabular}

\section{Subtopic 1.5 Suggested Approach for Learning about ATT and for Staying Current}

What are the best resources to help novices become familiar with these technologies and stay current with trends and progress?

Becoming conversant and expert enough to effectively use ATT is not a simple task or one to be accomplished overnight or over a weekend. It is like learning a new language and then watching that language evolve quickly before your eyes. The world of ATT is changing very fast. The table below lists several helpful hints that a novice should take seriously when venturing into ATT. 
Table 24. Suggestions for acquiring and maintaining ATT knowledge and familiarity.

\begin{tabular}{|c|c|}
\hline $\begin{array}{l}\text { Determine goals first, then } \\
\text { add technology support. } \\
\text { (Apply principles from the } \\
\text { Systematic Approach to } \\
\text { Training) }\end{array}$ & $\begin{array}{l}\text { There is so much going on that a wise novice (and everyone } \\
\text { else) will think first in terms of what instructional objectives } \\
\text { to which he or she might apply ATT. Establishing } \\
\text { instructional goals and objectives first, then selecting } \\
\text { supporting technology, helps define if and what technology } \\
\text { will be effective. }\end{array}$ \\
\hline $\begin{array}{l}\text { Become knowledgeable } \\
\text { through networking with } \\
\text { others. }\end{array}$ & $\begin{array}{l}\text { Advances in technology are constant and overwhelming. No } \\
\text { one has all the answers. Ask colleagues, other professionals, } \\
\text { vendors, and students. Various professional associations } \\
\text { exist to support this kind of networking as do user's groups } \\
\text { and online discussion groups. Within DOE, TRADE has an } \\
\text { ATT special interest group to foster just this kind of } \\
\text { networking. }\end{array}$ \\
\hline $\begin{array}{l}\text { Make onsite visits to } \\
\text { facilities, training centers, } \\
\text { trade shows, etc., to gain } \\
\text { firsthand knowledge. }\end{array}$ & $\begin{array}{l}\text { Most educators and trainers are willing to share their } \\
\text { successes and lessons learned. In addition, some states and } \\
\text { civilian schools and large corporations have established } \\
\text { experimental "model technology schools" to test } \\
\text { implementation techniques. }\end{array}$ \\
\hline $\begin{array}{l}\text { Attend conferences, } \\
\text { workshops and training } \\
\text { sessions. }\end{array}$ & $\begin{array}{l}\text { Go to conferences and workshops that emphasize hands-on } \\
\text { training, provide well-planned materials for future reference, } \\
\text { include lesson integration strategies, and promote } \\
\text { interchange with other educators and trainers. The number } \\
\text { of conferences and workshops being offered in this area is } \\
\text { exploding. Two representative ones for beginners are the } \\
\text { semi-annual SALT and IDLCON/TELCON conferences. }\end{array}$ \\
\hline Subscribe to periodicals. & $\begin{array}{l}\text { Publications keep up with the latest developments in } \\
\text { research, integration ideas, and product reviews. Multimedia } \\
\text { Today, Multimedia World, and the Heller Report are } \\
\text { examples of those focusing on multimedia. A number are } \\
\text { pointed to distance learning, CBT development, simulation, } \\
\text { and so forth. This area is also exploding. }\end{array}$ \\
\hline
\end{tabular}


Table 24. Suggestions for acquiring and maintaining ATT knowledge and familiarity.

\begin{tabular}{||l|l||}
\hline \hline $\begin{array}{l}\text { Play with public domain and } \\
\text { shareware sources. }\end{array}$ & $\begin{array}{l}\text { Public domain software is available at no cost and may be } \\
\text { freely copied. Shareware often offers an outstanding } \\
\text { opportunity to jump in without great initial costs. }\end{array}$ \\
\hline $\begin{array}{l}\text { Pick up evaluation copies of } \\
\text { courseware. }\end{array}$ & $\begin{array}{l}\text { As with shareware, it may be possible to evaluate retail } \\
\text { courseware before buying. This is actually a form of self- } \\
\text { education as well. Trade shows are a wonderful time to } \\
\text { learn what is happening by trying out as many products as } \\
\text { possible. Obviously, quality documentation and tutorials are } \\
\text { important and can alleviate much of the frustration involved } \\
\text { with installing and learning new products. }\end{array}$ \\
\hline Use technical support. & $\begin{array}{l}\text { Technical representatives at trade shows can be some of the } \\
\text { best tutors around. After a product is acquired, access to } \\
\text { quality technical support is invaluable. A toll-free number is } \\
\text { important. }\end{array}$ \\
\hline
\end{tabular}

\section{Subtopic 1.6 Emerging Technologies}

\section{What technologies are just emerging (becoming widely available) and how might these impact near term and long-term planning?}

A constraint was established at the beginning of this study to focus on existing and available ATT. The types of literature reviewed, conferences attended, facilities and organizations visited (except for a few R\&D organizations) reflected this constraint. The advantage of that decision is that it bounds the study and makes it meaningful to look at what is out there now (the second part of this report). Continued research is certainly needed to answer this question beyond the hints and previews that were obtained.

The following are ten hints and previews of things that are just emerging:

1. Use of Virtual Reality. Various prototype programs are continuing both in basic research and in applied fields such as waste management.

2. Full motion video on CD-ROMs. Higher data capacity. 
3. The distance learning world is going through a massive revolution with reduced costs for land-based video conferencing as well as digital satellite conference. Cable Interactive television and data will be delivered to the home. Dramatically improved interfaces to aid in navigating channels, storing and retrieving programming, etc.

4. Internet multimedia based training.

5. Internet-supported simultaneous multimedia interactivity.

6. Improved intelligent tutoring systems.

7. More wide-spread use of context and simulation.

8. Ties between systems thinking models and instructional design.

9. Rapid prototyping and simulation development environments.

10. Shifting from workstations to smart tools (essentially built-in performance support systems). 


\section{TOPIC 2. ACTUAL ATT USE AND LESSONS LEARNED}

This section documents the answers to the second set of questions, relating to the actual use of ATT and the lessons learned from actual use. Obtaining the answers meant reviewing case studies and reports of advanced technologies use, conducting numerous telephone interviews, attending several presentations of papers related to specific organizations' experiences applying $\mathrm{ATT}$, and visiting over two dozen facilities or institutions.

Prior to the conduct of site visits, a brief but intensive literature review was performed; two trade conferences were attended, one focusing on multimedia and the other on distance learning. Information gathered from similar trips but not funded by this study was also reviewed including a trip made to the Whittle Incorporated headquarters in Knoxville, Tennessee and to the Advanced Training Group at the Westinghouse Hanford Company in Richland, Washington. Materials collected through six years of attendance at the Utah State University's Annual Training Technology Workshops were also reviewed. Since the initial visits were completed, the Training Resources and Data Exchange (TRADE) and the Interservice/Industry Training Systems and Education (I/ITSEC) Conferences were attended.

Visits were made to the Mid-Atlantic region (Maryland, Washington, D.C., Virginia), the Intermountain West (Eastern Washington, Utah, Idaho, Colorado), the Southeast (Florida, South Carolina, Georgia, Tennessee), the Southcentral area (Texas) and the Southwest (New Mexico). The institutions visited, were selected because they have characteristics in common with the DOE (e.g., size, headquarters and field offices, diversity of function, risk, high technology) or because they were believed to be on the leading edge. Regrettably, entire sections of the country were missed (West, Northwest, Midwest, New England) because of time and resource constraints. A remarkable amount of overlap in experience, advice, and lessons learned from the surveyed institutions was observed.

\section{Subtopic 2.1 Use of ATT in Surveyed Organizations}

\section{Among those organizations surveyed, how widespread is the use of advanced technologies at similar government agencies, within the military, in industry, and in academia?}

Table 25 below lists the institutions visited or learned about through personal interviews, attendance at conference sessions, or published literature. Appendix B includes a table listing the same institutions but with additional details such as the types of audiences served, needs met, technology used, and ownership of resources. Points of contact at the time of the study are also included in the appendix.

The information provided in the body of the report and in Appendix B is synthesized. In many cases, visits were made to one small part of large organizations. The information in this report covers only those facilities visited or otherwise surveyed of these large organizations, not the entire organization. In Table 25, next to the name of the organization visited are designators 
for how the information was obtained. $A{ }^{\text {" }} \mathrm{V}$ " indicates that the facility or institution was visited personally by a member of the research team. Many of the organizations visited are also reported in the literature or are the subject of conference presentations. Twenty-six visits were made.

Information regarding the remaining 24 organizations included in this survey was obtained from interviews ("T"), attending conference presentations (" $C$ "), or from available professional literature ("L"). In many cases more than one means was used to obtain information (e.g., I,C,L).

Table 25 also lists the advanced training technologies being used in the various organizations surveyed. Information in this column will become dated very rapidly and was assumed to be accurate as of early 1994. The purpose of breaking out the media types is to allow more direct application of lessons learned from each organization and from comparisons. As noted previously, there is widespread confusion in the training world today because all multimedia (and advanced training technology) are discussed as though they are equal when they clearly are not. Note that distance learning (teleconferencing and computer networking) and few cases of technology common to the traditional classroom are listed next to the label Non-CBT.

A large percentage of the organizations surveyed either have started using some type of multimedia or distance learning or are in the process of exploring these options. Several of the organizations surveyed were selected because they were known to be exemplary in one or more areas. Also, the survey was focused on a single portion of a large organization and may have missed learning about other distance learning or multimedia activities going on in other portions of the same organization. 
Table 25. List of organizations visited or otherwise researched and related media information.

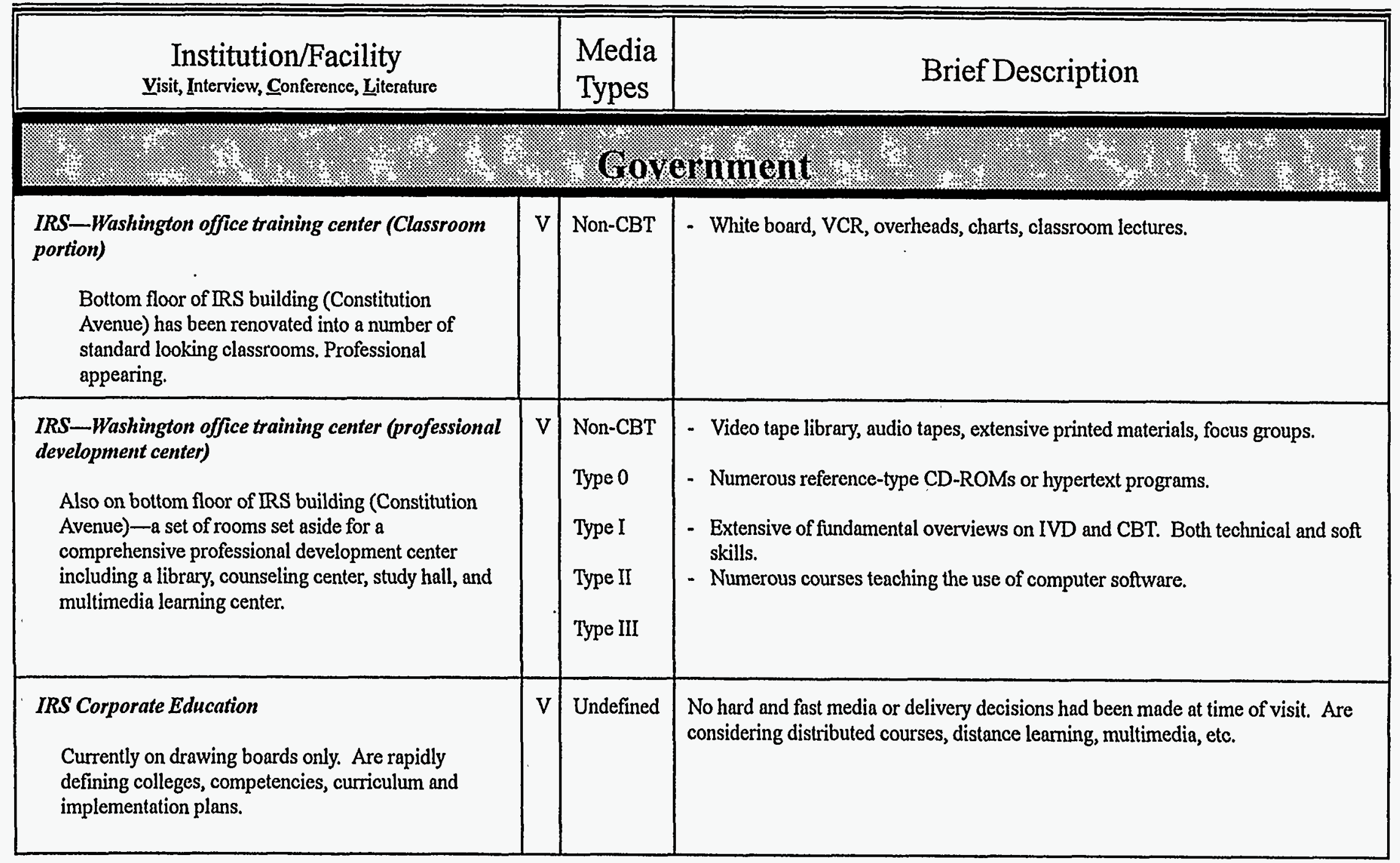


Table 25. List of organizations visited or otherwise researched and related media information.

\begin{tabular}{|c|c|c|c|}
\hline $\begin{array}{c}\text { Institution/Facility } \\
\text { Visit, Interview, Conference, Literature }\end{array}$ & & $\begin{array}{l}\text { Media } \\
\text { Types }\end{array}$ & Brief Description \\
\hline $\begin{array}{l}\text { United States Department of Agriculture (USDA) } \\
\text { Graduate School } \\
\text { Institution of higher learning under the umbrella of } \\
\text { the Department of Agriculture but entirely cost- } \\
\text { reimbursable. Wide range of courses serving } \\
\text { government employees in many agencies. Vast } \\
\text { number of courses offered in Washington, D.C. } \\
\text { Space and instructors are essentially all contracted. } \\
\text { Contract services elsewhere. Most courses are } \\
\text { accredited. Also provides support services for a } \\
\text { number of government agencies. }\end{array}$ & $\mathrm{V}$ & $\begin{array}{l}\text { Non-CBT } \\
\text { Other }\end{array}$ & $\begin{array}{l}\text { - Information obtained indicated that all courses are taught in classrooms, most } \\
\text { using traditional lecture and textbook format. } \\
\text { Contracted services do include some advanced technology development and } \\
\text { management. }\end{array}$ \\
\hline $\begin{array}{l}\text { United States Office of Personnel Management } \\
\text { (OPM), Washington DC Regional Training Center } \\
\text { Housed in a recently refurbished 12-story office } \\
\text { building in Arlington, Virginia. Large inimber of } \\
\text { classrooms. One of several regional training centers, } \\
\text { nationwide. Setting up a multimedia training center. } \\
\text { Have several rooms for computer training. Most } \\
\text { instructors are contracted. Almost all instructional } \\
\text { development is contracted and supervised by regional } \\
\text { offices, though coordinated centrally. }\end{array}$ & V & $\begin{array}{l}\text { Non-CBT } \\
\text { Type } 0 \\
\text { Type I } \\
\text { Type II } \\
\text { Type III }\end{array}$ & $\begin{array}{l}\text { - VCRs, whiteboards, overheads, charts available in classrooms. } \\
\text { - None observed (presumably some IVD or CD-ROM-based courseware in media } \\
\text { center will be hypertext reference aids). } \\
\text { - None observed (presumably some IVD or CD-ROM-based courseware in media } \\
\text { center will contain informational overviews or fundamentals courses). } \\
\text { - Computer systems training. }\end{array}$ \\
\hline $\begin{array}{l}\text { United States State Department National Foreign } \\
\text { Affairs Training Center } \\
\text { Recently completed a beautiful, large custom-built, } \\
\text { campus in Arlington, VA. Many sizes and types of } \\
\text { classrooms and training facilities. Does not provide } \\
\text { residency or accreditation. Looks and feels like a } \\
\text { small college campus (minus dorms and student } \\
\text { union). Extensive curriculum. }\end{array}$ & $\mathrm{V}$ & $\begin{array}{l}\text { Non-CBT } \\
\text { Type } 0 \\
\text { Type I } \\
\text { Type II } \\
\text { Type III }\end{array}$ & $\begin{array}{l}\text { - Teleconferencing capabilities (satellite downlink), VCR, library, unusual } \\
\text { facilities to meet special needs (e.g., jail, display rooms, simulation rooms, etc.). } \\
\text { - Extensive CD-ROM reference look-up training for new consul training. } \\
\text { - Extensive multimedia and audio-based training for language acquisition. } \\
\text { - Probably available in multimedia centers. }\end{array}$ \\
\hline
\end{tabular}


Table 25. List of organizations visited or otherwise researched and related media information.

\begin{tabular}{|c|c|c|c|}
\hline $\begin{array}{c}\text { Institution/Facility } \\
\text { Visit, Interview, Conference, Literature }\end{array}$ & & $\begin{array}{l}\text { Media } \\
\text { Types }\end{array}$ & Brief Description \\
\hline $\begin{array}{l}\text { United States Government Services Agency (GSA) } \\
\text { Interagency Training } \\
\text { Leased rooms (10 classrooms, } 1 \text { office suite) in a } \\
\text { Crystal City office building. Easy access via subway. } \\
\text { Development and instructors are contracted. }\end{array}$ & $\mathrm{V}$ & $\begin{array}{l}\text { Non-CBT } \\
\text { Other }\end{array}$ & $\begin{array}{l}\text { - Standard. } \\
\text { - Some classrooms are set up to teach computer skills. These may use Type I or II } \\
\text { media. }\end{array}$ \\
\hline $\begin{array}{l}\text { United States Government Accounting Office (GAO) } \\
\text { Remodeled portion of the GAO HQ building (about } \\
10 \text { years ago). Includes several classrooms and a } \\
\text { small multimedia learning center. Professional look } \\
\text { and feel. Experimenting with distance learning. }\end{array}$ & $\mathrm{v}$ & $\begin{array}{l}\text { Non-CBT } \\
\text { Types 0-II } \\
\text { Type III }\end{array}$ & $\begin{array}{l}\text { - Standard. } \\
\text { - Multimedia center includes general CBT courseware ranging from type } 0 \text { to } 11 \text {. }\end{array}$ \\
\hline $\begin{array}{l}\text { United States Nuclear Regulatory Commission (NRC) } \\
\text { Technical Training Center (TTC) } \\
\text { Located in an office building in Chattanooga, TN. } \\
\text { Occupies } 4 \text { floors. Houses staff, classrooms, and a } \\
\text { half-dozen full-scope simulators. }\end{array}$ & $\mathrm{v}$ & $\begin{array}{l}\text { Non-CBT } \\
\text { Type } 0 \\
\text { Type I } \\
\text { Type II } \\
\text { Type III }\end{array}$ & $\begin{array}{l}\text { - Standard plus video projection. } \\
\text { - Classrooms support video projection from numerous sources including IVD } \\
\text { plant walk-around. Classrooms wired into building and NRC networks. } \\
\text { - Group-based introductions and displays that are projected in classroom. } \\
\text { - Can initiate simulator runs and get results from classrooms. Can exercise mini- } \\
\text { simulation sequences. } \\
\text { - Can observe, initiate, and play back open-ended simulation data in classroom. }\end{array}$ \\
\hline $\begin{array}{l}\text { United States Nuclear Regulatory Commission (NRC) } \\
\text { White Flint II Training Center } \\
\text { Recently completed center in Rockville, MA. Brand- } \\
\text { new building with three computer training } \\
\text { classrooms. Four regular classrooms with LCD } \\
\text { projection and movable teleconferencing setup. } \\
\text { Innovative information access concepts for students } \\
\text { under development. Also a multimedia learning } \\
\text { center and lending library. }\end{array}$ & $\mathrm{V}$ & $\begin{array}{l}\text { Non-CBT } \\
\text { Types 0-II } \\
\text { Type III }\end{array}$ & $\begin{array}{l}\text { Standard plus land-based video conferencing capable. (Portable units that can } \\
\text { be brought into classroom to allow teaching course at multiple sites.). } \\
\text { - Multimedia learning center includes courses and materials at these levels. } \\
\text { (Unable to determine exact levels as center was not operational at the time of the } \\
\text { visit). Exploring the possibility of downloading CBT courseware to individual } \\
\text { workstations over their network. } \\
\text { - The NRC network will eventually be able to tie classrooms or multimedia } \\
\text { centers to simulation capabilities at NRC Technical Training Center. }\end{array}$ \\
\hline
\end{tabular}


Table 25. List of organizations visited or otherwise researched and related media information.

\begin{tabular}{|c|c|c|c|}
\hline $\begin{array}{c}\text { Institution/Facility } \\
\text { Visit, Interview, Conference, Literature }\end{array}$ & & $\begin{array}{l}\text { Media } \\
\text { Types }\end{array}$ & Brief Description \\
\hline $\begin{array}{l}\text { Federal Bureau of Investigation (FBI) Training } \\
\text { Center } \\
\text { Ten to twenty-year-old residence campus facility in } \\
\text { Quantico, VA. Houses } 1000 \text { students at a time. } \\
\text { Currently going through extensive classroom } \\
\text { modernization. In addition to classrooms has a } \\
\text { number of labs and outdoor ranges and mockup } \\
\text { training facilities. Most instructors are permanent } \\
\text { staff members or regular FBI agents on assignment. }\end{array}$ & $\mathrm{v}$ & $\begin{array}{l}\text { Non-CBT } \\
\text { Types 0-II } \\
\text { Type III }\end{array}$ & $\begin{array}{l}\text { - Advanced media-supported classrooms. } \\
\text { - Large ( } 50 \text { or more) multimedia center used to teach computer skills and support } \\
\text { CBT. Specific courseware not examined but assumed to have ranged through all } \\
\text { three types. } \\
\text { - Not known. }\end{array}$ \\
\hline $\begin{array}{l}\text { Federal Aviation Administration (FAA) } \\
\text { Have various central and regional training centers } \\
\text { (not visited). Searching for ways to reduce training } \\
\text { costs. Have completed extensive mission analysis, } \\
\text { market survey, cost-effectiveness analysis for use of } \\
\text { 1-way video and 2-way audio for higher education } \\
\text { and training. }\end{array}$ & $\begin{array}{l}\mathrm{I} \\
\mathrm{C} \\
\mathrm{L}\end{array}$ & $\begin{array}{l}\text { Non-CBT } \\
\text { Other }\end{array}$ & $\begin{array}{l}\text { Seriously exploring distance learning options to reduce travel and schoolhouse } \\
\text { costs. Analysis and survey results are available. Show net savings of up to } \\
\$ 65 \mathrm{M} \text { over } 10 \text { years. } \\
\text { - Not studied. }\end{array}$ \\
\hline $\begin{array}{l}\text { United States Postal Service } \\
\text { Large training center in Norman, OK. Extensive use } \\
\text { of distance learning. }\end{array}$ & $\begin{array}{l}\mathrm{C} \\
\mathrm{L}\end{array}$ & $\begin{array}{l}\text { Non-CBT } \\
\text { Others }\end{array}$ & $\begin{array}{l}\text { Wide-scale use of distance learning including satellite-based conferencing and } \\
\text { audio teleconferencing. } \\
\text { - Not studied. }\end{array}$ \\
\hline $\begin{array}{l}\text { United States Department of Energy (DOE) Central } \\
\text { Training Academy (CTA) } \\
\text { Moving rapidly from traditional classroom instruction } \\
\text { to distance learning and multimedia-supported } \\
\text { learning. Have recently completed distance learning } \\
\text { studio and uplink facility. Are developing and } \\
\text { disseminating multimedia courses. Located in } \\
\text { Albuquerque, NM. }\end{array}$ & $\mathrm{V}$ & $\begin{array}{l}\text { Non-CBT } \\
\text { Type } 0 \\
\text { Type I } \\
\text { Type II } \\
\text { Type III }\end{array}$ & $\begin{array}{l}\text { - Standard classroom media. Energetic efforts underway to produce distance } \\
\text { learning courses. Several prototype classes have been taught. Others planned. } \\
\text { - Courses developed to date are probably at this level. } \\
\text { - Exploring simulation-based courses at this level. }\end{array}$ \\
\hline
\end{tabular}


Table 25. List of organizations visited or otherwise researched and related media information.

\begin{tabular}{|c|c|c|c|}
\hline $\begin{array}{l}\text { Institution/Facility } \\
\text { Visit, Interview, Conference, Literature }\end{array}$ & & $\begin{array}{l}\text { Media } \\
\text { Types }\end{array}$ & Brief Description \\
\hline $\begin{array}{l}\text { Westinghouse Hanford Company (WHC) } \\
\text { Managing contractor for Hanford Site (DOE). Runs } \\
\text { three multimedia learning centers of } 25 \text { learning } \\
\text { stations each, serving } 15,000 \text { employees. One center } \\
\text { is located in community college and used by college } \\
\text { during evening hours. System has been in place for a } \\
\text { number of years. Has high acceptance and utilization } \\
\text { rates and has shown significant cost savings. Careful } \\
\text { scheduling. Extensive management support. }\end{array}$ & $\mathrm{V}$ & $\begin{array}{l}\text { Non-CBT } \\
\text { Type } 0 \\
\text { Type I } \\
\text { Type II } \\
\text { Type III }\end{array}$ & $\begin{array}{l}\text { - Standard. } \\
\text { - Regular status reports to DOE-ER Assistant Secretary via CD-ROM } \\
\text { hypermedia format. Includes stills, maps, charts, motion sequences, reports and } \\
\text { articles. } \\
\text { - Hanford General Employee Training (refresher). Requirements-driven } \\
\text { information pretested and taught as needed until mastery achieved. } \\
\text { - Radiation, Hazcom and other IVD courses. Moving rapidly to CD-ROM } \\
\text { format. }\end{array}$ \\
\hline $\begin{array}{l}\text { Savannah River Site (WSRS) } \\
\text { Eight multimedia learning centers consisting of 15-20 } \\
\text { learning stations each. Serving separate departments. } \\
\text { Provides skill training, primarily. Some utilization } \\
\text { problems. }\end{array}$ & $\mathrm{V}$ & $\begin{array}{l}\text { Non-CBT } \\
\text { Type } 0 \\
\text { Type I } \\
\text { Type II } \\
\text { Type III }\end{array}$ & $\begin{array}{l}\text { - Standard. } \\
\text { - Much of the courseware developed by local contractor is at this level. } \\
\text { - Exploring the use of constrained simulation in various CBT products. }\end{array}$ \\
\hline
\end{tabular}


Table 25. List of organizations visited or otherwise researched and related media information.

\begin{tabular}{|c|c|c|c|}
\hline $\begin{array}{c}\text { Institution/Facility } \\
\text { Visit, Interview, Conference, Literature }\end{array}$ & & $\begin{array}{l}\text { Media } \\
\text { Types }\end{array}$ & Brief Description \\
\hline $\begin{array}{l}\text { EG\&G, Idaho } \\
\text { Former site contractor for the Idaho National } \\
\text { Engineering Laboratory. At time of survey was using } \\
\text { traditional classrooms. In the process of establishing } \\
\text { a small multimedia center. }\end{array}$ & $\mathrm{V}$ & $\begin{array}{l}\text { Non-CBT } \\
\text { Type } 0 \\
\text { Other }\end{array}$ & $\begin{array}{l}\text { - Standard plus video-conferencing links between site and town. } \\
\text { - Extensive Gopher and WWW servers for DOE (Technical Information System) } \\
\text { and dissemination of other reports and conference proceedings. } \\
\text { - Under consideration for purchase or development. }\end{array}$ \\
\hline $\begin{array}{l}\text { United States Air Force Academy } \\
\text { Located in Colorado Springs, CO, the U.S. Air Force } \\
\text { Academy has several multimedia learning centers that } \\
\text { are used primarily to deliver language and history } \\
\text { courses. Cadets each have personal computer in } \\
\text { dorm rooms that are completely networked. Many } \\
\text { classes also have networked computers. }\end{array}$ & V & $\begin{array}{l}\text { Non-CBT } \\
\text { Type } 0 \\
\text { Type I } \\
\text { Type II } \\
\text { Type III }\end{array}$ & $\begin{array}{l}\text { - Standard. } \\
\text { - Computer networks support lookup and access to information. } \\
\text { - Elaborate history of air power using exciting multimedia constructs. } \\
\text { - Assumed to have some of these for language and other courses. }\end{array}$ \\
\hline $\begin{array}{l}\text { United States Air Force Institute of Technology } \\
\text { Teaching a number of courses via a large satellite } \\
\text { network. 1-way video, 2-way audio. Located at the } \\
\text { Wright Patterson, AFB in Dayton, OH. }\end{array}$ & $\begin{array}{l}\text { C } \\
\text { L }\end{array}$ & Non-CBT & - Extensive use of satellite teleconferencing. \\
\hline $\begin{array}{l}\text { United States Air University } \\
\text { Traditional school house education and training } \\
\text { located in Montgomery, AL. Rapidly moving into } \\
\text { distance education and multimedia options in } \\
\text { cooperation with Air Force Institute of Technology. }\end{array}$ & I & $\begin{array}{l}\text { Non-CBT } \\
\text { Types 0- } \\
\text { III }\end{array}$ & $\begin{array}{l}\text { - Standard, along with download capable of courses provided by Air Force } \\
\text { Institute of Technology and other feeders. } \\
\text { - Status unknown. }\end{array}$ \\
\hline
\end{tabular}


Table 25. List of organizations visited or otherwise researched and related media information.

\begin{tabular}{|c|c|c|c|}
\hline $\begin{array}{l}\text { Institution/Facility } \\
\text { Visit, Interview, } \text { Conference, Literature }\end{array}$ & & $\begin{array}{l}\text { Media } \\
\text { Types }\end{array}$ & Brief Description \\
\hline $\begin{array}{l}\text { United States Air Force Air Combat Command } \\
\text { Supported work on innovative multimedia training of } \\
\text { troubleshooting for aircraft maintenance. Located at } \\
\text { Hill AFB, Ogden, UT. }\end{array}$ & $\begin{array}{l}\text { C } \\
\text { L }\end{array}$ & $\begin{array}{l}\text { Types II- } \\
\text { III }\end{array}$ & - Presentation and papers discuss advanced troubleshooting training. \\
\hline $\begin{array}{l}\text { Brooks/Randolph Air Force Bases (San Antonio, TX) } \\
\text { Brooks and Randolph AFBs in San Antonio, TX., } \\
\text { conducts research and feasibility studies on new } \\
\text { training technologies for incorporation in the Air } \\
\text { Force training commands. }\end{array}$ & $\mathrm{V}$ & $\begin{array}{l}\text { Types II- } \\
\text { III }\end{array}$ & - Research efforts into intelligent tutoring systems that are either at type II or III. \\
\hline $\begin{array}{l}\text { United States Army Research Institute (Orlando, FL) } \\
\text { Studying potential of virtual reality for Army training. }\end{array}$ & V & $\begin{array}{l}\text { Types II- } \\
\text { III }\end{array}$ & $\begin{array}{l}\text { - Virtual reality-based simulations (currently researching interfaces and usability } \\
\text { issues). }\end{array}$ \\
\hline $\begin{array}{l}\text { United States Army Research Institute (Boise, Idaho) } \\
\text { Extensive experience with a wide variety of } \\
\text { multimedia for remote training. Leaders in Army } \\
\text { application of asynchronous computer conferencing. }\end{array}$ & $\mathrm{y}$ & $\begin{array}{l}\text { Non-CBT } \\
\text { Type I }\end{array}$ & $\begin{array}{l}\text { Exploring wide range of distance learning options including asynchronous } \\
\text { computer conferencing and simulators. } \\
\text { - Explored use of introductory CBT for remote learning and review }\end{array}$ \\
\hline $\begin{array}{l}\text { United States Army Logistics Management College } \\
\text { (Fort Lee, Va) } \\
\text { Extensive 1-way satellite, 2-way audio instruction. } \\
\text { Several studios. Train instructors in distance learning } \\
\text { teaching methods. }\end{array}$ & $\begin{array}{l}\text { C } \\
\text { L }\end{array}$ & Non-CBT & - Satellite-based 1-way video teleconferencing ( 2 way audio). \\
\hline $\begin{array}{l}\text { United States Army Professional Training } \\
\text { HQ for network for satellite training (2-way video } \\
\text { and audio) called VTT located in Fort Eustis, VA. }\end{array}$ & $\begin{array}{l}\mathrm{C} \\
\mathrm{L}\end{array}$ & Non-CBT & - Two-way video and two-way audio, satellite-based network. \\
\hline
\end{tabular}


Table 25. List of organizations visited or otherwise researched and related media information.

\begin{tabular}{|c|c|c|c|}
\hline $\begin{array}{l}\text { Institution/Facility } \\
\text { Yisit, Interview, Conference, Literature }\end{array}$ & & $\begin{array}{l}\text { Media } \\
\text { Types }\end{array}$ & Brief Description \\
\hline $\begin{array}{l}\text { United States Army Artillery School (Fort Sill) } \\
\text { Extensive use of VTT. Also multimedia learning } \\
\text { center adjacent to satellite classroom. }\end{array}$ & $\begin{array}{l}\text { C } \\
\text { L }\end{array}$ & $\begin{array}{l}\text { Non-CBT } \\
\text { Types I- II } \\
\text { Type III }\end{array}$ & $\begin{array}{l}\text { - Part of VTT. Use of portable uplink to provide New Equipment Team Training. } \\
\text { - Multimedia learning center. }\end{array}$ \\
\hline $\begin{array}{l}\text { United States Army National Defense University- } \\
\text { Information Resources Management College (NDU- } \\
\text { IRM) } \\
\text { Beautiful facility situated at Fort McNair. Teaches } \\
\text { advanced officer education program courses in } \\
\text { Information Resource Management and Information } \\
\text { Warfare. }\end{array}$ & $\mathrm{V}$ & $\begin{array}{l}\text { Group- } \\
\text { CBT } \\
\text { Type } 0 \\
\text { Types I- II } \\
\text { Type III }\end{array}$ & $\begin{array}{l}\text { - Well equipped classrooms with computer supported lectern to control projector, } \\
\text { connect with network, etc. Have computer decision support center. } \\
\text { - Library access to various reference CD-ROMs and on-line services. } \\
\text { - Setting up multimedia learning center. Computer skills training. }\end{array}$ \\
\hline $\begin{array}{l}\text { Defense Acquisition University (DAU) } \\
\text { Located in Alexandria, VA., a virtuai university } \\
\text { consisting of small staff who define competencies, } \\
\text { contract courses, prioritize attendance requests. } \\
\text { Studying distance learning options. }\end{array}$ & $\mathrm{V}$ & $\begin{array}{l}\text { Non-CBT } \\
\text { Type } 0\end{array}$ & $\begin{array}{l}\text { - Primarily traditional classroom oriented. Conducted study to evaluate feasibility } \\
\text { of using distance learning options. } \\
\text { - Distributes catalog as hypertext document. }\end{array}$ \\
\hline $\begin{array}{l}\text { United States Navy Medical Training } \\
\text { Located in Bethesda, MD., they developed over } 400 \\
\text { medical multimedia and delivered worldwide to } \\
\text { Navy Medical Personnel. }\end{array}$ & $\mathrm{L}$ & $\begin{array}{l}\text { Type } 0 \\
\text { Types I- II } \\
\text { Type III }\end{array}$ & - Courses mentioned in presentation appeared to be at this level. \\
\hline
\end{tabular}


Table 25. List of organizations visited or otherwise researched and related media information.

\begin{tabular}{|c|c|c|c|}
\hline \multicolumn{2}{|l|}{$\begin{array}{l}\text { Institution/Facility } \\
\text { Visit, Interview, Conference, Literature }\end{array}$} & $\begin{array}{l}\text { Media } \\
\text { Types }\end{array}$ & Brief Description \\
\hline $\begin{array}{l}\text { United States Naval Training Systems Center } \\
\text { Researching team training methodologies simulation } \\
\text { fidelity requirements. }\end{array}$ & $\begin{array}{l}\text { C } \\
\text { L }\end{array}$ & $\begin{array}{l}\text { Non-CBT } \\
\text { Types II- } \\
\text { III }\end{array}$ & $\begin{array}{l}\text { - Exploring the role of training team communications. } \\
\text { - Investigating levels of physical fidelity required in simulation to achieve } \\
\text { effective results. }\end{array}$ \\
\hline ?14. & & (:) & asterl, \\
\hline $\begin{array}{l}\text { Dow Chemical Company } \\
\text { Advanced learning classroom facility in Midland, } \\
\text { Michigan. Designed for professional educational } \\
\text { courses. }\end{array}$ & $\begin{array}{l}\text { I } \\
\text { L }\end{array}$ & $\begin{array}{l}\text { Group- } \\
\text { CBT }\end{array}$ & - Advanced classroom with all kinds of group-based multimedia support. \\
\hline $\begin{array}{l}\text { Arthur Andersen \& Company } \\
\text { Large residence-style facility in St. Charles, } \\
\text { Illinois-houses } 1800 \text { students. Provides initial } \\
\text { education for new hires, continuing education and } \\
\text { customer training. }\end{array}$ & $\begin{array}{l}\text { I } \\
\text { L }\end{array}$ & $\begin{array}{l}\text { Non-CBT } \\
\text { Types II- } \\
\text { III }\end{array}$ & $\begin{array}{l}\text { - Standard. } \\
\text { - Very sophisticated professional capstone package. Utilizes case-based approach } \\
\text { and expert-systems engines to provide high interactivity. }\end{array}$ \\
\hline $\begin{array}{l}\text { Motorola University } \\
\text { Teaches generic courses that apply company-wide. } \\
\text { Also does extensive development for new corporate } \\
\text { initiatives such as quality, empowerment, and } \\
\text { re-engineering. Standard classroom facilities. } \\
\text { Located in Schumberg, } \mathbb{L} \text {. }\end{array}$ & $\mathrm{L}$ & $\begin{array}{l}\text { Non-CBT } \\
\text { Types I-II } \\
\text { Type III }\end{array}$ & $\begin{array}{l}\text { - Standard. } \\
\text { - Moving toward more multimedia-based training. Currently a small percentage } \\
\text { of education and training done electronically. }\end{array}$ \\
\hline
\end{tabular}


Table 25. List of organizations visited or otherwise researched and related media information.

\begin{tabular}{|c|c|c|c|}
\hline $\begin{array}{l}\text { Institution/Facility } \\
\text { Yisit, Interview, Conference, Literature }\end{array}$ & & $\begin{array}{l}\text { Media } \\
\text { Types }\end{array}$ & Brief Description \\
\hline $\begin{array}{l}\text { IBM Skill Dynamics Technical Training Center } \\
\text { Huge classroom and lab building in Atlanta, GA., } \\
\text { where they train maintenance personnel for all their } \\
\text { computers from PCs to Mainframes. }\end{array}$ & $\mathrm{v}$ & $\begin{array}{l}\text { Non-CBT } \\
\text { Type I-III }\end{array}$ & $\begin{array}{l}\text { Some computer-supported classroom. Extensive group-based computer and } \\
\text { maintenance training. } \\
\text { - Has learning centers in most major cities where IVD-based equipment is used to } \\
\text { teach a wide variety of courseware. Also has separate group developing } \\
\text { Electronic Performance Support Systems. }\end{array}$ \\
\hline $\begin{array}{l}\text { Caterpillar Incorporated } \\
\text { Providing extensive satellite-based training to } \\
\text { marketing reps. Also developing and distributing } \\
\text { multimedia training to customers on maintenance of } \\
\text { their hardware. Located in Peoria, } \mathbb{L} \text {. }\end{array}$ & $\begin{array}{l}I \\
L\end{array}$ & $\begin{array}{l}\text { Non-CBT } \\
\text { Type } 0 \\
\text { Types I- II } \\
\text { Type III }\end{array}$ & $\begin{array}{l}\text { - Widespread use of satellite conferencing within marketing side of organization. } \\
\text { - Use of CD-ROM for reference. } \\
\text { - Skill training for customers. }\end{array}$ \\
\hline $\begin{array}{l}\text { Union Pacific Railroad } \\
\text { Providing training on new tracking system to blue- } \\
\text { collar workers using multimedia learning stations in a } \\
\text { dozen learning centers. Located in Lincoln, NE. }\end{array}$ & $\begin{array}{l}\mathrm{I} \\
\mathrm{L}\end{array}$ & $\begin{array}{l}\text { Type II } \\
\text { Type III }\end{array}$ & - Extensive IVD-based course to teach computer system. \\
\hline $\begin{array}{l}\text { Shell Oil } \\
\text { Providing much of the skill training at an oil refinery } \\
\text { using multimedia learning center. Located in } \\
\text { Shreveport, LA. }\end{array}$ & $\mathrm{L}$ & $\begin{array}{l}\text { Type I } \\
\text { Type II } \\
\text { Type III }\end{array}$ & $\begin{array}{l}\text { - Introductory skill training. } \\
\text { - More advanced process and interface training. }\end{array}$ \\
\hline
\end{tabular}


Table 25. List of organizations visited or otherwise researched and related media information.

\begin{tabular}{|c|c|c|c|}
\hline \multicolumn{2}{|l|}{$\begin{array}{l}\text { Institution/Facility } \\
\text { Visit, Interview, Conference, Literature }\end{array}$} & $\begin{array}{l}\text { Media } \\
\text { Types }\end{array}$ & Brief Description \\
\hline $\begin{array}{l}3 M \\
\text { Utilizing land-based video conferencing as well as } \\
\text { extensive satellite reception to provide continuing } \\
\text { education to engineers. Located in St. Paul, MN. }\end{array}$ & I & Non-CBT & $\begin{array}{l}\text { - Extensive use of distance learning to promote professional development of } \\
\text { engineers. }\end{array}$ \\
\hline i & & $4.8 \%$ & 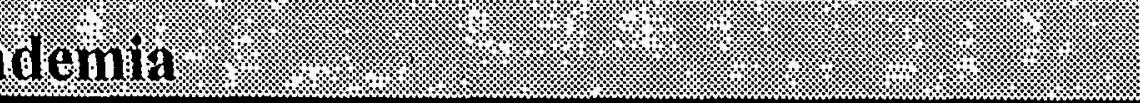 \\
\hline $\begin{array}{l}\text { Brigham Young University } \\
\text { Several multimedia equipped classrooms. Some with } \\
\text { rear projection, others with two ceiling-mounted } \\
\text { video projectors. Learning labs. Continuing } \\
\text { education. Located in Provo, UT. }\end{array}$ & $\mathrm{V}$ & $\begin{array}{l}\text { Group- } \\
\text { CBT } \\
\text { Types 0- } \\
\text { II }\end{array}$ & $\begin{array}{l}\text { - Several advanced multimedia classrooms. } \\
\text { - Variety of courseware in several multimedia learning centers and labs. } \\
\text { Mechanical engineering lab set up with advanced simulation capabilities. }\end{array}$ \\
\hline $\begin{array}{l}\text { Utah State University } \\
\text { Leaders in instructional theory and in finding ways to } \\
\text { reduce costs of multimedia development. Have } \\
\text { several multimedia projects and a multimedia } \\
\text { presentation only classroom. Located in Logan, UT. }\end{array}$ & $\mathrm{V}$ & $\begin{array}{l}\text { Group- } \\
\text { CBT } \\
\text { Type I-II } \\
\text { Type III }\end{array}$ & $\begin{array}{l}\text { - Some multimedia classrooms, extensive distance learning capabilities. } \\
\text { - Learning labs (one for Department of Education observed first hand) including a } \\
\text { wide variety of courseware on several different kinds of platforms. } \\
\text { - Involved in developing tools to create lower-cost Type II and III simulations. }\end{array}$ \\
\hline $\begin{array}{l}\text { Florida State University, Center for Educational } \\
\text { Technology } \\
\text { Developing prototype electronic performance support } \\
\text { system for instructors and students using wireless } \\
\text { pen-based technology. Located in Tallahassee, FL. }\end{array}$ & $\mathrm{V}$ & $\begin{array}{l}\text { EPSS } \\
\text { (Types 0- } \\
\text { II) }\end{array}$ & $\begin{array}{l}\text { - Designing instructor support tools and student learning tools and standards that } \\
\text { could be used within the Florida school system. }\end{array}$ \\
\hline
\end{tabular}


Table 25. List of organizations visited or otherwise researched and related media information.

\begin{tabular}{|c|c|c|c|}
\hline $\begin{array}{l}\text { Institution/Facility } \\
\text { Visit, Interview, } \text { Conference, Literature }\end{array}$ & & $\begin{array}{l}\text { Media } \\
\text { Types }\end{array}$ & Brief Description \\
\hline $\begin{array}{l}\text { University of Central Florida, Institute for Simulation } \\
\text { and Training } \\
\text { Located in Orlando, FL., a model high tech classroom } \\
\text { with multimedia projection, group interaction via } \\
\text { computer at each desk. }\end{array}$ & $\mathrm{V}$ & $\begin{array}{l}\text { Group- } \\
\text { CBT } \\
\text { Types I- II } \\
\text { Type III }\end{array}$ & $\begin{array}{l}\text { - Advanced multimedia classroom, supporting VTT and SimNet and other large } \\
\text { dynamic simulations. } \\
\text { - Developer of various CBT products. } \\
\text { - Support SimNet. }\end{array}$ \\
\hline $\begin{array}{l}\text { University of Florida, Medical School } \\
\text { Utilizes IVD to provide interns with examples and } \\
\text { CBT for ultrasound and other specialty areas. } \\
\text { Priceless video clips were captured over many years } \\
\text { of experience and show a wide range of possible } \\
\text { situations physicians may face. Located in } \\
\text { Gainesville, FL. }\end{array}$ & $\mathrm{v}$ & Type I & $\begin{array}{l}\text { Excellent interactive hypermedia approach to expose interns and residents to } \\
\text { real cases in systematic or random access fashion. }\end{array}$ \\
\hline $\begin{array}{l}\text { University of Illinois, Urbana Champaign } \\
\text { Several innovative multimedia projects that teach } \\
\text { complex analysis and decisionmaking skills }\end{array}$ & $\begin{array}{l}1 \\
C \\
L\end{array}$ & Type I-II & $\begin{array}{l}\text { Implementation of cognitive flexibility theory. Uses multimedia to allow } \\
\text { multiple traverscs across conceptual landscapes. }\end{array}$ \\
\hline $\begin{array}{l}\text { University of Maryland } \\
\text { Two high-tech classrooms. Designed by group of } \\
\text { computer scientists, cognitive scientists, and media } \\
\text { experts, have created and use regularly teaching } \\
\text { theaters with computers for each student. Interactive } \\
\text { classroom-based multimedia environment. Located } \\
\text { in College Park, MD. }\end{array}$ & $\begin{array}{l}\mathrm{V} \\
\mathrm{I} \\
\mathrm{L}\end{array}$ & $\begin{array}{l}\text { Group- } \\
\text { CBT }\end{array}$ & $\begin{array}{l}\text { Very sophisticated multimedia based classrooms. Instructor can control all } \\
\text { kinds of CBT for presentation to whole class. Students can E-mail one another } \\
\text { or have their work displayed for whole class. Connections to distance learning } \\
\text { environment. }\end{array}$ \\
\hline
\end{tabular}


Table 25. List of organizations visited or otherwise researched and related media information.

\begin{tabular}{|c|c|c|c|}
\hline $\begin{array}{l}\text { Institution/Facility } \\
\text { Yisit, Interview, } \underline{\text { Conference, Literature }}\end{array}$ & & $\begin{array}{l}\text { Media } \\
\text { Types }\end{array}$ & Brief Description \\
\hline $\begin{array}{l}\text { Vanderbith, Cognition and Technology Group } \\
\text { Located in Nashville, TN., a group of computer } \\
\text { scientists (AI), cognitive scientists, and media } \\
\text { experts, creating highly interactive group-based } \\
\text { multimedia learning tools. Effectively teach math and } \\
\text { soft skills using media support. }\end{array}$ & $\begin{array}{l}\text { I } \\
\text { C } \\
\text { L }\end{array}$ & $\begin{array}{l}\text { Group- } \\
\text { CBT } \\
\text { Type II } \\
\text { Type III }\end{array}$ & $\begin{array}{l}\text { - Standard, use of IVD to teach elementary students science and math concepts. } \\
\text { - Soft skills training. }\end{array}$ \\
\hline $\begin{array}{l}\text { University of Pittsburgh, LRDC } \\
\text { Located in Pittsburgh, PA., a group of computer } \\
\text { scientists (AI) and cognitive scientists creating } \\
\text { intelligent tutors for teaching complex } \\
\text { troubleshooting skills. }\end{array}$ & $\begin{array}{l}C \\
L\end{array}$ & Type III & $\begin{array}{l}\text { - Sherlock-a system for intelligent tutoring of aircraft maintenance } \\
\text { troubleshooting. }\end{array}$ \\
\hline $\begin{array}{l}\text { Northwestern University } \\
\text { Group of computer scientists (AI), cognitive } \\
\text { scientists, and media experts, creating highly } \\
\text { interactive group-based multimedia learning tools. }\end{array}$ & $\begin{array}{l}\mathrm{C} \\
\mathrm{L}\end{array}$ & $\begin{array}{l}\text { Group- } \\
\text { CBT } \\
\text { Type II } \\
\text { Type III }\end{array}$ & $\begin{array}{l}\text { - Group-based advanced multimedia courseware for journalism (prototype). } \\
\text { - Produced Arthur Andersen's capstone exercises. }\end{array}$ \\
\hline
\end{tabular}


The summary table below provides specific percentages of distance learning and multimedia use.

Table 26. Summary of distance learning and multinedia use for organizations surveyed.

\begin{tabular}{|c|c|c|c|c|}
\hline : & Sriverainent: & Minuar: & 17.misg & 4.9n日enina \\
\hline Yuil Bistance & $12 \%$ & $29 \%$ & $11 \%$ & $0 \%$ \\
\hline 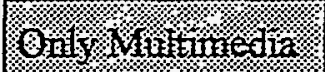 & $35 \%$ & $43 \%$ & $67 \%$ & $50 \%$ \\
\hline 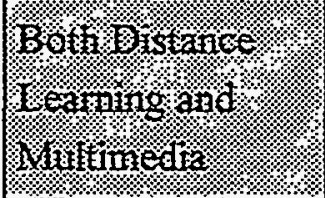 & $29 \%$ & $21 \%$ & $22 \%$ & $50 \%$ \\
\hline 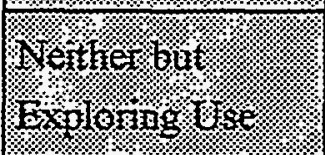 & $12 \%$ & $7 \%$ & $0 \%$ & $0 \%$ \\
\hline 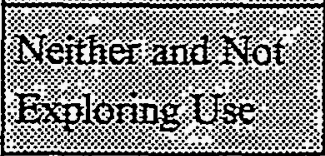 & $12 \%$ & $0 \%$ & $0 \%$ & $0 \%$ \\
\hline 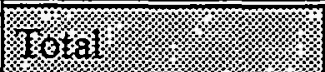 & $100 \%$ & $100 \%$ & $100 \%$ & $100 \%$ \\
\hline
\end{tabular}

A surprising number of the organizations surveyed appear to be tied to traditional models of teaching-teachers who tell and students who listen. Most of these organizations have maintained their classroom orientation, using ATT to extend the classroom via distance learning, or providing the instructor with tools for information network and computer-based presentation rather than producing individualized multimedia products and learning centers.

\section{Subtopic 2.2 Types of ATT Found}

\section{What types of distance learning and multimedia technologies are being used?}

Table 27 below shows what percentage of the institutions surveyed are using which types of distance learning and which types of multimedia. 
Table 27. Summary of distance learning and multimedia types used.

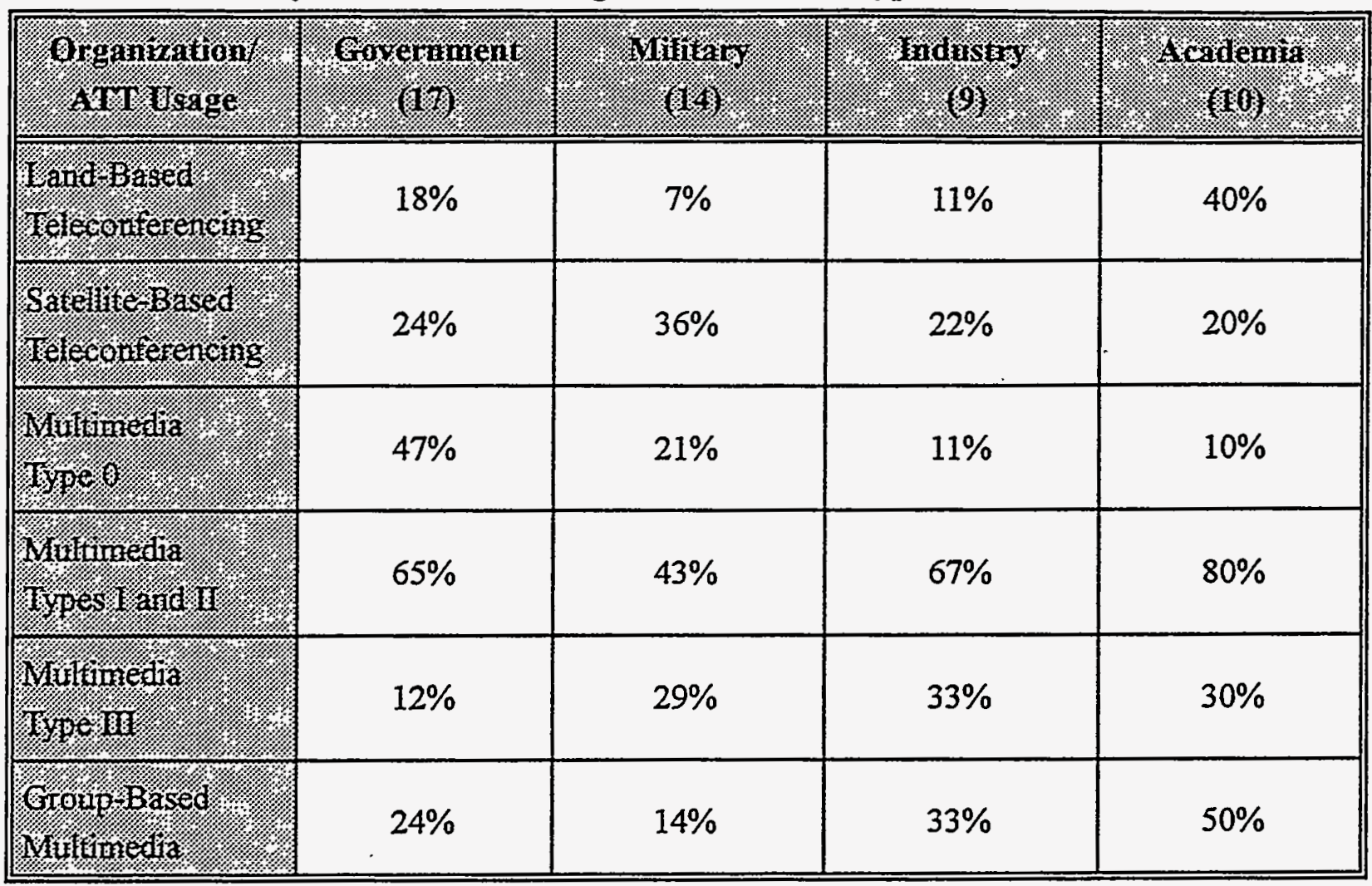

\section{Subtopic 2.3 ATT-Related Organizational and Implementation Strategies Observed}

How are representative institutions incorporating ATT into their organizations and into their existing or planned physical facilities?

Two other ways of asking this question are, "What types of centralization or decentralization activities were observed and in what areas?" and "Where and when did organizations find it useful to centralize delivery and development of training?" Additionally, "What range of approaches were observed relative to ownership of resources, control of instructional activities, and focus of offerings and selectivity of audience served?" Table 28 below shows the variety of answers observed relative to each of these questions, each presented as a separate continuum with two end points and a mid point. 
Table 28. Continuum of organizational aspects observed.

\begin{tabular}{|c|c|c|c|}
\hline m. & 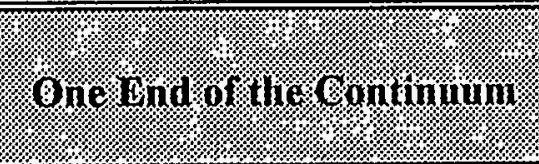 & \%. & 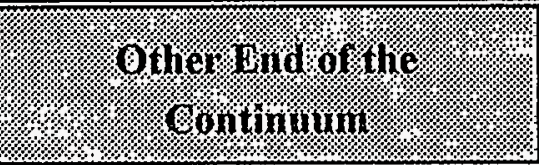 \\
\hline 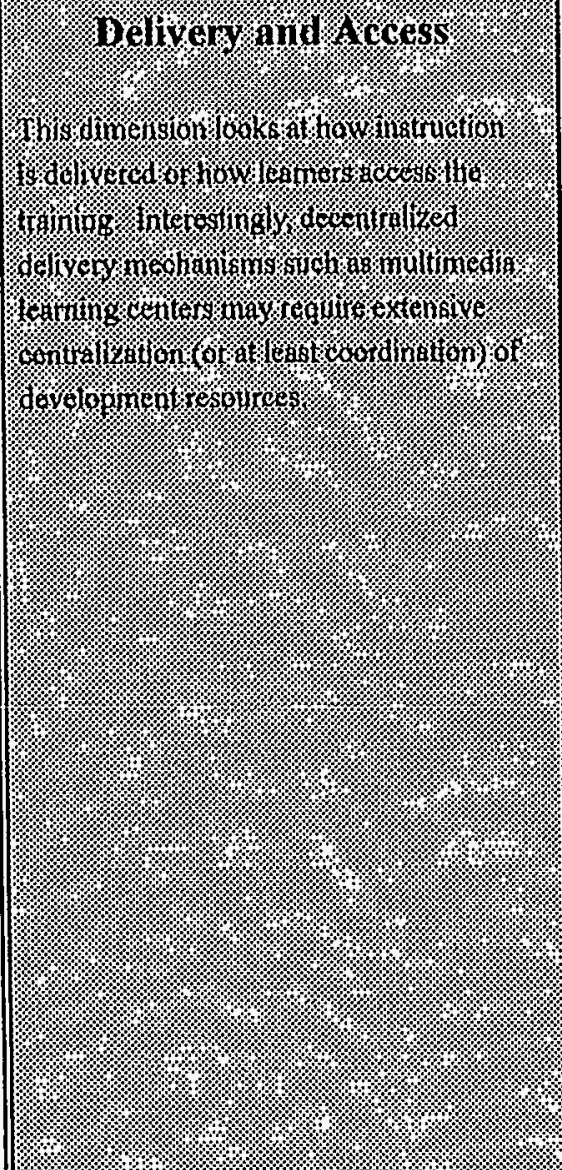 & $\begin{array}{l}\text { Distributed Access } \\
\text { The Navy Medical program researched } \\
\text { has developed some } 400 \text { courses for } \\
\text { delivery via IVD (and now CD-ROM). } \\
\text { The discs and booklets are sent to } \\
\text { hundreds of locations around the world } \\
\text { including all the ships whose medics have } \\
\text { multimedia workstations. The same } \\
\text { machines are available port-side so the } \\
\text { medics can access the information } \\
\text { virtually anywhere, anytime. }\end{array}$ & $\begin{array}{l}\text { Mixed Access } \\
\text { The NRC is exploring methods of } \\
\text { improving access to computer-based } \\
\text { materials, videotapes, and printed } \\
\text { materials. In addition to two centralized } \\
\text { training centers (one in Rockville, the } \\
\text { other in Chattanooga), the NRC is looking } \\
\text { at lending out courseware for home } \\
\text { computer use or distributing copies on } \\
\text { their network. } \\
\text { Distance lcarning options such as audio } \\
\text { and vidco teleconferencing provide many } \\
\text { of the advantages of distributed access } \\
\text { (especially when conpared to attending a } \\
\text { resident course somewhere). Currently } \\
\text { for most video conferencing, students } \\
\text { must congregate in a room specially } \\
\text { equipped to receive a broadcast and with } \\
\text { some kind of response system. With both } \\
\text { satellite and cable being used to broadcast } \\
\text { many for-credit educational programs, the } \\
\text { convenience and distributiveness of these } \\
\text { distance leaming methods are dramatically } \\
\text { increasing and will continue to do so. }\end{array}$ & $\begin{array}{l}\text { Centralized Access } \\
\text { Some institutions, in sceking to provide } \\
\text { individualized multimedia, have } \\
\text { completely centralized their education and } \\
\text { training functions and built a few centers } \\
\text { to which all learners must come. A good } \\
\text { example of this is Westinghouse Hanford } \\
\text { where all annual refresher GET training is } \\
\text { conducted in three learning centers. } \\
\text { Because of careful scheduling, their usage } \\
\text { rates are high. }\end{array}$ \\
\hline
\end{tabular}


Table 28. Continuum of organizational aspects observed.

\begin{tabular}{|c|c|c|c|}
\hline 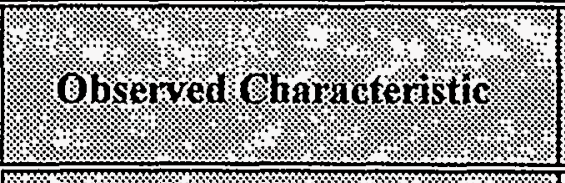 & 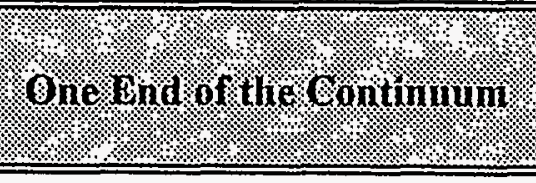 & 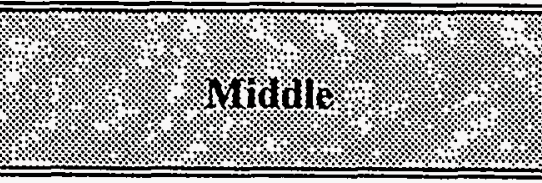 & (1.2. \\
\hline 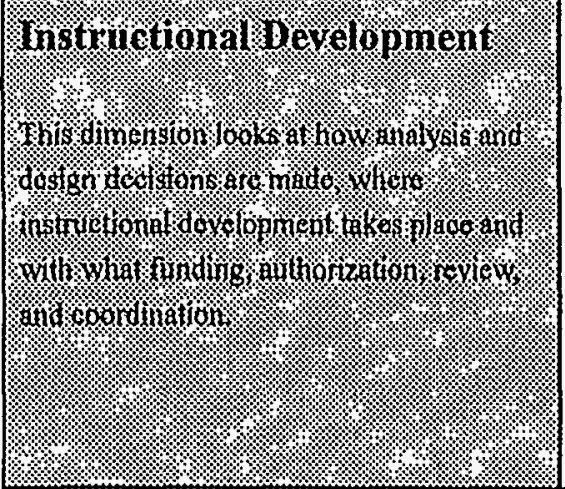 & $\begin{array}{l}\text { Until recently, most of the instructional } \\
\text { development within the DOE system has } \\
\text { been essentially decentralized. Each DOE } \\
\text { office, field office, and laboratory has } \\
\text { developed courses and materials } \\
\text { independently. Current efforts are } \\
\text { underway to move to a mixed or more } \\
\text { centralized development system. }\end{array}$ & $\begin{array}{l}\text { Motorola University provides cultural } \\
\text { change support to the Corporate President } \\
\text { and provides courses that are common to } \\
\text { more than one Motorola company. Single } \\
\text { company-specific training is not wilhin the } \\
\text { charter of the University. }\end{array}$ & $\begin{array}{l}\text { The IRS is developing a new curriculum } \\
\text { for its college of taxation which will be } \\
\text { completely centralized in terms of } \\
\text { objectives specification and development. } \\
\text { Development of broad-based military } \\
\text { training has long been standardized. }\end{array}$ \\
\hline 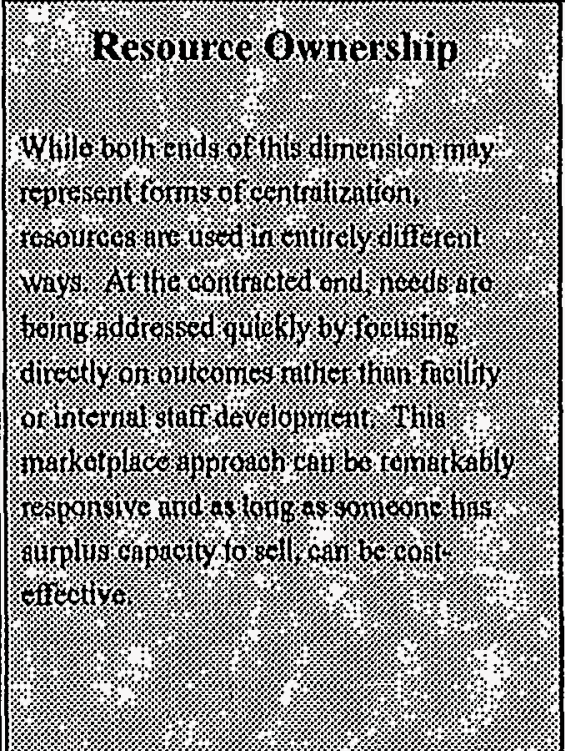 & $\begin{array}{l}\text { Totally Contracted } \\
\text { The Defense Acquisition University } \\
\text { (DAU) has a } \$ 100 \mathrm{M} \text { a year budget but } \\
\text { owns practically nothing; DAU owns no } \\
\text { classrooms, courseware, staff instructors, } \\
\text { cafeterias, nor dormitories. Instead, it } \\
\text { contracts for everything-buying 20-40 } \\
\text { thousand person-seats per year from } \\
\text { existing courses or from courses built by } \\
\text { other defense schools just for them. } \\
\text { Another example of this virtual ownership } \\
\text { is Metropolitan Life who has contracted } \\
\text { out all its corporate training as a single line } \\
\text { item to Skill Dynamics, an IBM } \\
\text { subsidiary. }\end{array}$ & $\begin{array}{l}\text { Partially Owned } \\
\text { This is becoming a popular option. } \\
\text { Numerous government agencies have a } \\
\text { small full-time staff involved in scheduling } \\
\text { and supporting the training, an even } \\
\text { smaller number of full-time faculty } \\
\text { members and administrators (and possibly } \\
\text { some equipment and facilities), and obtain } \\
\text { the bulk of their instructor staff and most } \\
\text { or all of their facilities through contract. } \\
\text { Examples include USDA Graduate } \\
\text { School, OPM Regional Training Centers, } \\
\text { and GSA Inter-agency Training Center. }\end{array}$ & $\begin{array}{l}\text { Totally Owned } \\
\text { IBM's Windy Hill Hardware Maintenance } \\
\text { Training Facility in Marietta, Georgia, is } \\
\text { owned by IBM and the entire staff is full- } \\
\text { time IBM employees. At the FBI } \\
\text { Academy in Quantico Virginia, all but a } \\
\text { few services, such as the cafeteria, are } \\
\text { owned and provided by the FBI. } \\
\text { Similarly, at Arthur Andersen and. } \\
\text { Company's St. Charles Professional } \\
\text { Development Center over a thousand } \\
\text { professionals are comfortably housed, fed, } \\
\text { and instructed while in residence. }\end{array}$ \\
\hline
\end{tabular}


Table 28. Continuum of organizational aspects observed.

\begin{tabular}{|c|c|c|c|}
\hline 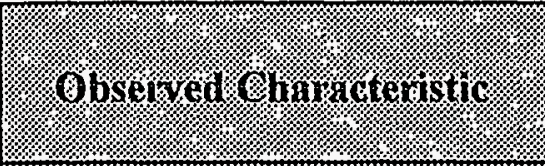 & 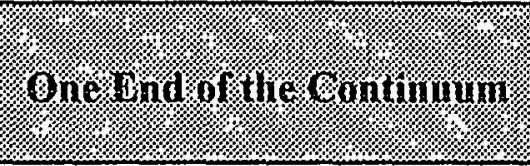 & Mtidale & r্যে: \\
\hline 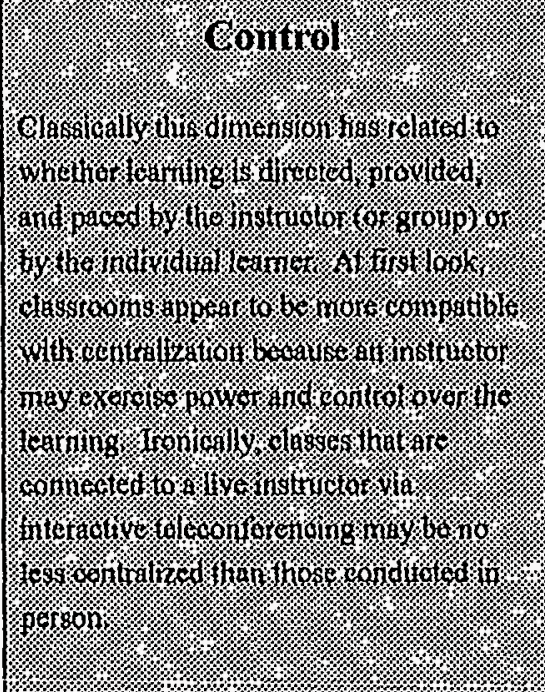 & $\begin{array}{l}\text { Learner Control } \\
\text { Shell Oil, Union Pacific, Hewlett-Packard } \\
\text { (Printer Division) and Westinghouse } \\
\text { Hanford have shifted much of the control } \\
\text { to the learners. These companies provide } \\
\text { many courses that are only available at } \\
\text { multimedia learning centers where the } \\
\text { students come at their convenience and } \\
\text { work at their own pace. } \\
\text { Several forms of Internet-based delivery } \\
\text { may require centralized support for } \\
\text { development but allow workstation access } \\
\text { and convenience. }\end{array}$ & $\begin{array}{l}\text { Dow Chemical and University of } \\
\text { Maryland have constructed highly } \\
\text { interactive classrooms or teaching theaters } \\
\text { where instructors orchestratc and present } \\
\text { via a large variety of media but where } \\
\text { students can also present and interact with } \\
\text { the instructor and other students via } \\
\text { computer-mediated communications } \\
\text { channels. } \\
\text { Computer conferencing is another } \\
\text { example in which both the instructor } \\
\text { (moderator) and leamers share control.. }\end{array}$ & $\begin{array}{l}\text { The NRC Technical Training Center and } \\
\text { FBI Academy are good examples of } \\
\text { ATT's use to enhance the teaching in the } \\
\text { classroom but not provide learner- } \\
\text { centered tools. } \\
\text { Much distance learning that is conducted } \\
\text { via video or audio conferencing is an } \\
\text { extension of the instructor-directed } \\
\text { classroom. }\end{array}$ \\
\hline
\end{tabular}




\begin{tabular}{|c|c|c|c|}
\hline 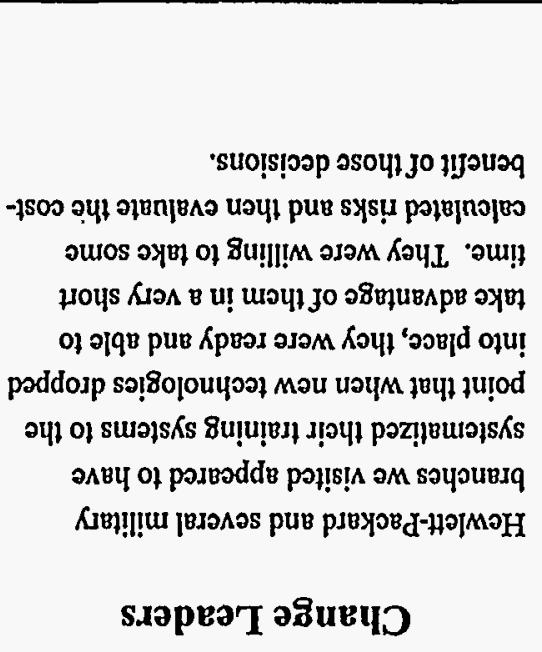 & & 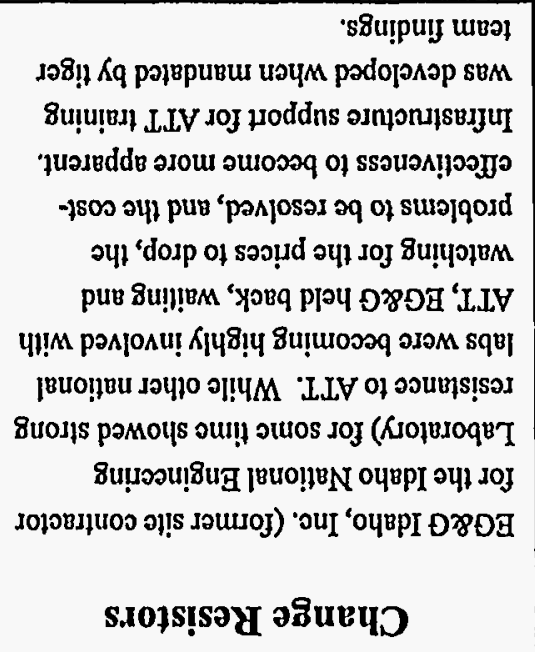 & 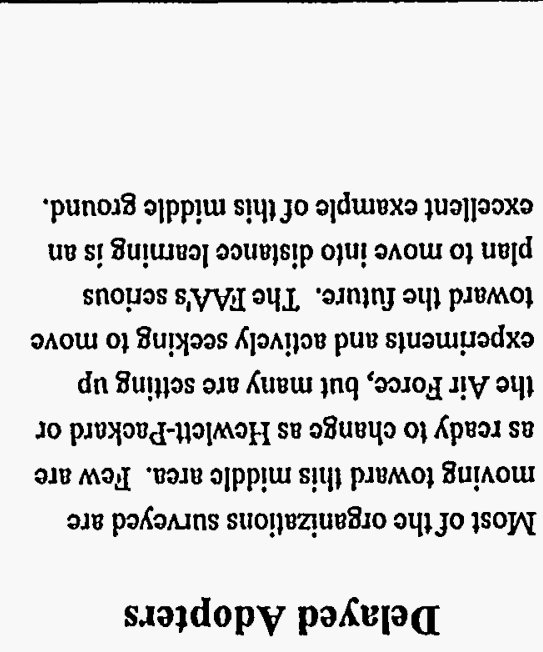 \\
\hline 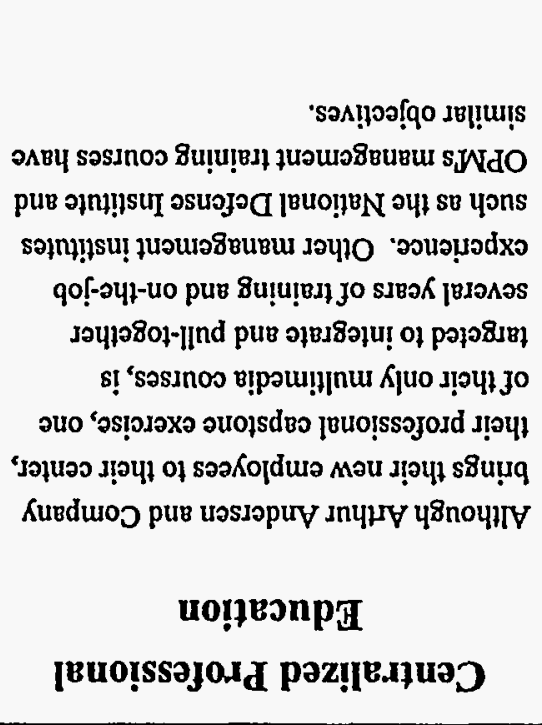 & 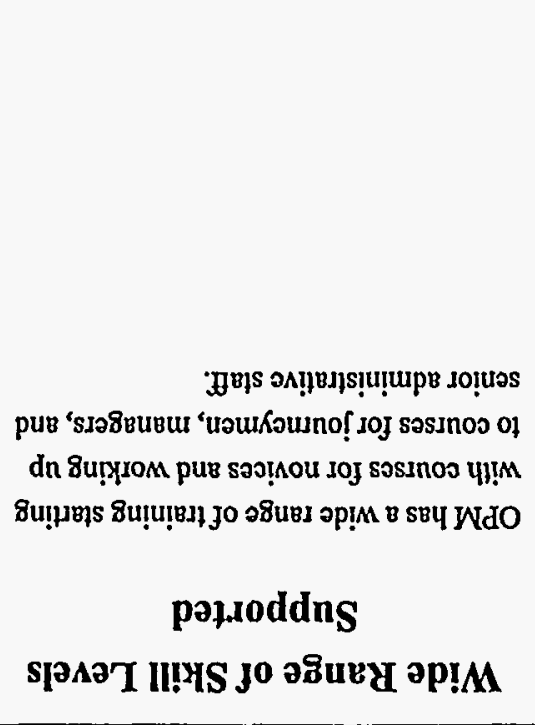 & 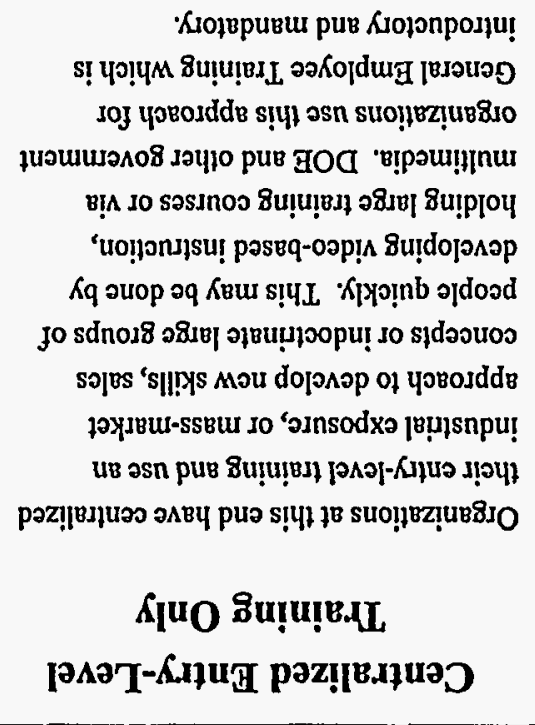 & 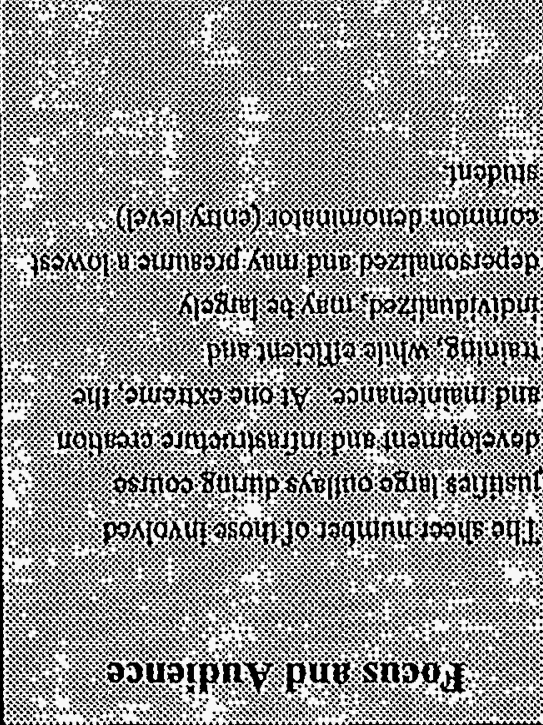 \\
\hline ४ & (4) & unnumor & 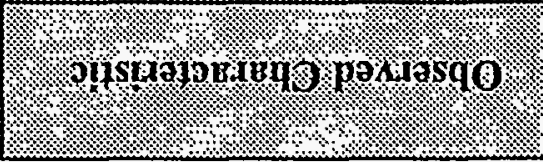 \\
\hline
\end{tabular}

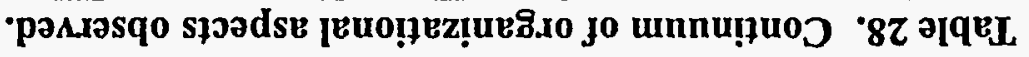




\title{
Subtopic 2.4 Exceptional ATT-Related Practices Observed
}

\author{
What are some of the most exceptional practices and most notable successes in utilizing \\ ATT?
}

Of those institutions surveyed, the bright stars in distance learning appeared primarily in the military, particularly the Air Force Institute of Technology and Army Logistics Command, both of which have many years of experience, have excellent studios, high usage rates, and courses for familiarizing new instructors with this approach. Hewlett-Packard (HP) is one of the preeminent corporate users of distance learning and multimedia. Over the years HP has been able to move quickly when the cost-effectiveness of new technologies is apparent. Several universities and private companies marketing education credit are gaining wide recognition including the Maine Educational Network, National Technological University, and Mind Expansion University. Several transportation and chemical processing giants have invested heavily in ATT with good results (e.g., Union Pacific, Shell Oil). Within the DOE system, Westinghouse Hanford Company and the Central Training Academy (CTA) have both been making great strides to acquire the infrastructure, skills, and processes to enable them to become long-term players in the ATT game. Westinghouse Hanford Company was one of the first to shift from instructor-led training to multimedia-based instruction and as a result has claimed millions of dollars in savings. The CTA has systematically moved from classroom-based training to both distance learning and multimedia-based training over the last few years. Other $D O E$ projects are emerging throughout the system to develop intelligent tutoring systems, expert systems-based performance support systems, emergency response simulation exercises, etc.

\section{Subtopic 2.5 Summary of ATT-Related Lessons Learned}

What lessons can be learned from other organizations' experiences with ATT and with centralized training facilities?

Twenty lessons learned have been identified from the survey. These are grouped into six areas: 1) training technology integration, 2) contracting, staffing, and resource management, 3) accreditation, 4) focus and audience, 5) cognitive engineering, and 6) systems thinking. Each of these areas is discussed in the following pages. 


\section{Training Technology Integration}

Many of the trade publications make it appear that all the answers to training problems will come through the adoption of the technology targeted by that publication. Clearly, some organizations have been able to make some dramatic break-throughs by adopting one particular technology. Union Pacific Railroad, for example, has successfully introduced an advanced computer-based tracking system to workers who were, for the most part, computer-illiterate. Other organizations have invested large amounts into facilities that feature the latest in advanced classroom technology and are geared to enable the instructor to present materials better. And still other institutions are investing heavily in distance learning to reduce direct travel costs and time lost to travel.

In addition to the many organizations looking at just one of these options, several were making plans to integrate all of these capabilities as well as new information search and retrieval and other electronic performance support tools. One training director noted that, in his opinion, over-focusing his company on one good technology has actually prevented them from staying current and using other technologies as they should.

\section{Lessons learned:}

1. The best technology selections may be a combined or integrated approach which would include basic or advanced classrooms, multimedia, and distance learning.

While it may be true that for certain training needs and for given organizations one basic solution is enough, evidence indicates many organizations are branching into (researching if not actually starting prototype efforts in) multimedia and CBT, distance learning, advanced classrooms, and improved information access and use. Those who have not seriously looked at all of these areas recently may run the risk of thinking they are in the training business and not the performance improvement business, and just as the railroads found themselves boxed in by their own self-definition, many training organizations may be unable to respond effectively or quickly enough to the re-engineering, downsizing, and restructuring taking place all over America. Some of these technologies require significant infrastructure but can produce remarkable cost savings if a sufficient planning horizon is used. The most remarkable organizations of the future may be those who combine most of these technologies into one cohesive, cost-effective system. 
2. Consider customizing a media selection model, then use it to help find the right balance between cost and quality.

A large number of media selections in the past have been based on political decisions rather than rational, instructionally sound decisions. It is often possible to get as much accomplished with a lower cost media as with one which costs more, assuming the instruction has been well-designed. Design aspects include allowing skipping over previously learned materials through test-outs, providing clear statements of the concepts or principles being taught, providing good examples and poor examples, and providing sufficient practice and feedback.

3. Seek specialized help and empower that help sufficiently to keep proper emphasis on users (OPM, FBI, State).

Once you are ready to build/refurbish a facility, find a media consultant who knows how to work with architects to ensure that learner's and instructor's needs receive the proper priority in space utilization, aesthetics, decor, etc. Consultants should also assist in specifics such as colors, lighting, networking, projection (ceiling versus rear versus portable), sound, etc. The FBI internal expert noted that having an external consultant on board and empowered can sometimes be much easier than acquiring an equal level of support for an internal expert.

4. Continually review what other training organizations in government, military, industry and DOE are doing with technology (i.e., don't develop the center and then think that it will remain state of the art).

Many organizations we visited were in the process of completing "environmental scans" similar to this study, though many were focused on one aspect of technology (i.e., distance learning or multimedia). Some organizations have regular review cycles where all new developments are assessed for impact on their plans. Many subscribe to newsletters and numerous trade publications and regularly attend conferences and trade shows to stay current. One area where we should see extensive development and potential application over the next few years is in the use of the Internet. Others are the expanded use of CD-ROM, especially for full-motion video, the use of desktop videoconferencing, and electronic performance support systems. 
5. Realize that even advanced technologies incorporated today will be mostly obsolete in three to five years and will need to be upgraded or replaced.

It may not be easy to accept the fact that the technology is constantly improving, especially once an organization's resources have been committed. Not keeping the hardware and software current essentially locks in old courseware which may no longer be accurate and may be less effective than newer courseware. This will be especially true as more cognitive engineering and human factors elements are built into the courseware which will then require more and more machine capability.

\section{Contracting, Staffing, Logistics and Resource Management}

Many of the organizations we visited are undergoing significant staff reductions or reorganizations as the result of downsizing, centralization, decentralization, and re-engineering. One company was "spun off" to be "pulled back in" and downsized again only three years later. Several organizations have completely shed themselves of full-time instructors and subject matter experts. One agency has gone from a staff of over 60 to one of 30 in a short time period; the remaining staff is primarily administrative. All courseware development (both instructional systems skills and subject matter knowledge) is being contracted out. Many organizations do not own the buildings where their training is conducted. The ultimate of contracting is the Defense Acquisition University where everything but analysis, planning, and coordination is contracted out.

Outsourcing development appears to be more the rule than the exception for traditional lecture-style training as well as for multimedia development and conversion to distance learning courses. Several directors were delighted by the current situation in which a surplus of capable contractors compete against each other and keep prices down. (We wonder whether the same market forces work when contract instructors are needed for courses in less cosmopolitan areas than Washington, D.C.).

The cost of becoming current in the newer technologies is high and the rate of change means that the knowledge of an internal person mastering a technology is already obsolete by the time he or she is an expert. Outsourcing development would appear to be a good hedge against this 
problem. On the other hand, a certain amount of internal knowledge is vital to making good decisions and evaluating contractor performance.

One disadvantage of outsourcing is that it can mean the lowest common denominator in terms of quality of instructors and media. Even if instructors belong to and facilities are owned by the organization, the instructors and staff will need extensive continuing education and training to be able to use advanced technologies to the best advantage.

Even the campus-like facilities usually outsource items such as food services. OPM uses a hotel to provide both room and board for its executive seminars in Denver, Colorado. No unanimity exists on whether providing room and board was necessary and beneficial or actually detrimental to the school.

Vendors are willing to provide a variety of goods and services, from a few hours of highlevel consulting to a complete turn-key training program as IBM Skill Dynamics has provided for Metropolitan Life.

\section{Lessons learned:}

6. Involve and train the instructors and staff in the use of the technologies. (University of Maryland, NRC, NDU-IRM).

Many new methods and media are left unused because the people who are expected to use them are not comfortable with them. Money spent on technology should be matched with dollars for inservice training.

7. Look beyond the current needs to allow for growth and expansion.

The director of the NRC Technical Training Center was very emphatic about this. His experience has been one of playing "catch up" for almost 20 years.

8. Consider residence-style living quarters (dormitories) for professional development-oriented courses or when extensive travel is involved.

When the training center is in a particularly remote location (such as Quantico) and the training lasts for several weeks, it can be advantageous to provide room and board. In 
addition to reducing the logistics problem for attendees, several positive side effects can occur including: development of networking and fiendships among peers attending the course, possible use of evening hours for optional social, cultural, or training-related activities. For example, the FBI Training Center has a learning lab with 50 or so multimedia workstations. These are available 24 hours a day (when classes have not reserved the room) and are always available in the evenings for those who need to brush up on skills or knowledge.

9. Consider centralizing infrastructure support of media, information resources, etc.

At the FBI Training Center, the rear-projection areas of all the classrooms are connected, making it possible for one or two media specialists to service all the classes. Several facilities now being designed do not have any electronic equipment in the classroom (except keyboards, monitors, and controls). All the VCRs, computers, IVD, and CD-ROMs are located in a media room where one technician maintains all the equipment and inserts the video tapes, video disks or CD-ROMs at the instructor's request.

10. Outsource most training tasks (with notable exceptions).

Most training development and delivery can be conducted competently by contract labor. However, for specialized technical training or senior-level professional development there are many advantages to building a faculty.

\section{Accreditation}

Several organizations (e.g., USDA Graduate School and the DOE Central Training Academy) place a lot of importance in accrediting their courses with the National Program on Noncollegiate Sponsored Instruction (PONSI) or specific professional organizations for continuing education credits. The number of organizations that have not yet done so is surprising. Whether this is due to time and budgetary constraints, the unique and narrow focus of their curriculum, or simply priorities is not clear. This certainly is an area that should be addressed. 


\section{Lessons learned:}

11. Where possible, establish college or other credits that can be transferred from the provided training.

Apparently, there are a number of possible side benefits from producing course documentation to the extent required for accreditation, including better overall analysis, design, and focus of the course. Those institutions most active in accrediting their courses appeared to use it as an "added-value" factor to attract students who might otherwise obtain the same course somewhere else. It also lends prestige to the institution.

\section{Focus and Audience}

Several of the training directors emphasize the importance of not trying to "do it all" in terms of what a school or training center should be designed to accomplish. They refer especially to not trying to be an executive development institute, a middle-level manager and professional education program, and a basic skills technical training center all rolled into one. It is not possible. Many organizations are also realizing that student time is the most expensive part of training, and they are trying to improve the overall cost-effectiveness of training by supporting the learner in any way possible.

\section{Lessons learned:}

12. Support the learner (Air Force Academy, Florida State University).

New paradigms being promoted in education and training look to learner-centered systems that provide information and training "just-in-time" rather than "just-in-case." Supporting the learning may include providing tools such as an electronic performance support system (EPSS), a computer-based tool that helps the worker perform a task more efficiently and effectively than would be possible without. IBM has found, for example, that most of the time spent in training for specialized work is wasted because the skills are forgotten, are not used, or not completely learned (it is often hard to learn complex skills without real contexts to practice them in). EPSSs may include standard desktop tools such as word processors, spreadsheets, calculators, electronic or other interactive communication, as well as context- 
sensitive help systems, tutors, coaches, and computer assisted learning materials. A sophisticated EPSS will assist when asked, passively observe the performer, or when appropriate make coaching, instruction, and other helps available.

13. Select terminology carefully. The terms "education" or "development" may be more acceptable to mid-level and senior staff than the term "training" (IRS, NDU-IRM, NRC).

The name of the center should help set expectations. Some organizations are turning away from the use of the term training, because they want their professionals to be competent in broadly defined, ever-changing job skills and competencies rather than trained in narrowly-defined tasks. Teach underlying competencies, if possible.

\section{Cognitive Engineering}

This is a new buzzword for applying good sound psychological principles relating to human information processing, learning, problem solving, and performance to instruction. Many important applications of cognitive engineering are emerging from research laboratories and are starting to make enormous improvements in learning time and effectiveness. Work done by Lesgold and colleagues at the University of Pittsburgh Learning Research and Development Center (LRDC) in intelligent tutoring is a good example of how novices can be taught very complex problem-solving skills in a few weeks (if not hours) rather than years. Similar work for the Air Force by Allen Communications and Educational Testing Service has yielded excellent results. Many organizations are moving toward job redesigning and job-aiding using electronic performance support systems which provide training and information "just-in-time" instead of "just-in-case." The State of Florida is actively pursuing the development of instructor and student learning tools that take full advantage of access to information resources, organizing and retrieval tools as well as built-in advisory help. Such systems may dramatically reduce the requirements for instructor-packaged content and for specific task-based training, and at the same time actually require that the human do more high-level "knowledge-based" thinking and solving problems. This case is being hypothesized by the IRS in their new Corporate Education program where they intend to cross-train individuals (who are business domain experts) in many areas of IRS work.

Situating the learning by creating a meaningful context for problem learning content and problem-solving skills, using rich examples and stories in case-based learning, and teaching students to look at a problem from a number of different perspectives--as promoted by cognitive flexibility theory-are all promising developments in the area of cognitive engineering. 


\section{Lessons learned:}

14. Provide for interactivity in instructional delivery (supported by numerous research studies).

Multi-media products, in addition to good instructional design, tend to provide for more individualization and tailoring by the delivery system for the needs of the learner. This includes more practice, and greater assurance that the learner is attending to the material being presented/learned.

15. Look for ways to leverage the learning method by tapping the knowledge of experts.

The Air Force has been particularly effective in finding methods for teaching complex skills to novices and helping them perform at expert levels in a short time. Arthur Andersen and Company's case-based capstone studies also help foster rapid learning. Some exciting work is taking place in the area of cognitive engineering and should receive as much attention as hardware and software technologies.

\section{Systems Thinking}

Several organizations are rethinking everything from top to bottom in trying to solve serious downsizing requirements or competitive needs. Systems thinking is a broad area that involves all those previously discussed and many more. It is the ultimate realism because it looks at long-term causes and effects rather than just the short-term, expedient or politically popular needs, problems, and solutions. Organizations that are able to think strategically about their mission and goals and then eventually translate those goals into mandates for education and training (such as Motorola University) seem to be using a whole different set of tools than organizations tied strictly to HRD and ISD models. Strategically-thinking organizations are actively searching out the best technologies (mental and physical) to meet their performance and communication needs. They are not afraid to innovate, to try something new. They are realistic about what it takes to create real change. Education and training is not treated reactively, the first to get the blame, the last to get resources. Nor is it allowed to stagnate. These organizations are willing to exercise patience in doing the right things right rather than constantly dashing out after quick fixes. In addition to Motorola, we noted evidence of excellent systems thinking by the IRS Corporate Education, Florida State University, University of Central Florida, FAA, and the NRC Technical Training Center. In contrast, several organizations seemed almost adrift, unable to surmount internal politics or past success. 


\section{Lessons learned:}

16. Use systems thinking in determining the need for training and technologies to be employed (Florida State University, IRS, NRC).

Identifying the long-term goals and plans of the supported institution should precede setting up a training center. Current and expected performance and cultural deficiencies can then be identified and various means set up to remedy those deficiencies. Education/training is one of many means for correcting deficiencies and creation of a center is only one of many options for delivery of courses.

17. First, identify the mission of the center (FAA, IRS, NRC, NDU-IRM).

Derive the mission from a needs analysis. Focus on "setting priorities." Once the mission (and strategic direction) is clear, solve other logistic and technical problems (such as type of facility required, type of media and teaching methods used, size and layout of classrooms, or studios, faculty and support staff required, contracting methods for outsourcing).

18. Look carefully at specific lessons learned from others before adopting multimedia and distance learning (FAA, Navy, DAU, NRC).

This field is changing rapidly and failures are expensive. For any kind of technology to be used, there are probably organizations that have already paid the price for trial and error and would be willing to help others avoid making the same mistakes.

19. Get stakeholders involved at the appropriate times (NRC, DAU, IRS).

This includes conducting a needs analysis (i.e., coming up with the training needs and requirements and competency definitions, the mission of training center, the methods used, and evolving needs).

Several institutions have established advisory boards to help perform needs analysis and secure buy-in and support from affected organizations. 
20. Build program evaluation into the quality management process (Air Force Academy, NRC, NDU-IRM).

Few of the programs examined have a strong evaluation component while most used only course evaluations of the instructors by the students as the primary evaluation tool. For real quality improvement to take place, an organization needs to be formal and systematic about how it evaluates itself. 



\section{TOPIC 3. APPROACHES FOR SELECTING, EVALUATING COST-BENEFIT AND STRATEGICALLY PLANNING FOR ATT USE.}

The third part of this report introduces and describes processes for selecting, evaluating, and strategically preparing for and incorporating ATT into DOE. While the previous two portions of this study have described the state of the art of ATT in general and of the 60 organizations surveyed, this part of the study presents methods and processes that organizations can use to decide just how appropriate ATT is for them. Three methods or processes are described including: 1) media-method selection methods, 2) cost-analysis approaches, and 3) technology readiness and acceptance models. The implications of these approaches for establishing a central training organization or training center are presented along with a prototype strategic plan.

The FAA, after performing an exhaustive study, reported that they had identified 50 or more models of media-selection methods. The difficulty, therefore, is not in finding methods but in tailoring them to meet the specific needs of the organization. One particular method is included in this study (see Appendix A) and in Subtopic 3.2. Another tool produced by the Army Research Institute (Boise Field Office) was also investigated. Neither is ideally suited for DOE without some customization.

An excellent text, Cost-Effectiveness, A Primer, New Perspectives in Evaluation, Vol.4, (Levin, 1985), was reviewed and abstracted to present some of the essential concepts of costeffectiveness, cost-benefit, cost-utility, and cost-feasibility analysis. Media-selection methods are very useful but are incomplete and need to be augmented with further data from feasibility, utility and effectiveness, and cost studies.

Finally, strategic models that have found wide acceptance in organizational development and software development were studied and an extrapolation made for purposes of training readiness and acceptance. ${ }^{5}$ These models examine organizational maturity, technology acceptance and readiness for change. In short, what may make sense in a fine-tuned spreadsheet may be all but impossible because of an organization's current level of maturity and its lack of readiness to move on.

\footnotetext{
${ }^{5}$ Because of time constraints, this extrapolated model has not been validated or submitted to peer review. However, as an approach, it applies well-established principles of quality, change management, and organizational development to organizational readiness to accept and effectively utilize ATT. While further validation of this model would be useful, it is believed that the model, as currently formulated, will help DOE and other decisionmakers in far-reaching and powerful strategic thinking.
} 


\section{Subtopic 3.1 General Media Selection Considerations}

What are some of the fundamental systems and performance improvement principles that provide the backdrop against which all media and method selection decisions are made?

Many media and method decisions are made by decisionmakers reacting to interest, guidance, or suggestions of their superiors or peers on the basis of what is popular, worked for a top competitor or sister organization, or is particularly glamorous. The purpose of this subtopic is to present seven important principles and related cautions that form the background context within which media and training technology decisions should be made. Since they are in the background, these principles are all too often forgotten or overlooked.

\section{Principle 1: Understand the problem before trying to fix it.}

Planners must develop a thorough understanding of the performance-related needs and problems they are trying to solve. Needs must drive media method decisions. Too often, decisionmakers turn to technology as the key to solving their problems before they even know what their problems are. This tends to compound the problems rather than solve them.

First understand the outcomes (standards) to be accomplished by the individuals in a system, then document the relative position of individuals to those standards. Closing whatever gap exists between the standard and the individual is the goal of the system. This process is formally known as needs assessment and is the process of identifying current or future deficiencies, then establishing target levels of performance, capability, or competency which individuals within the system should reach. Needs assessment also looks at the specifics of when certain knowledge and skills must be used and in what settings. Without a reality-based understanding of what is wrong, it is fairly certain that almost all proposed solutions will fail, regardless of how efficient these solutions might appear to be.

\section{Principle 2: Education and training is not a panacea and should often be used as the method of last resort.}

Only those performance-related needs caused by lack of knowledge and/or skill should be included as part of an education or training system. In the past, an implicit bias of many decisionmakers has been to fix performance problems through more training. This bias has lead to an explosion of mandatory (just-in-case) training requirements and an unnecessarily heavy 
overhead burden. A large number of performance problems can be resolved or prevented by setting up better methods for selecting and advancing personnel into various jobs (recruiting, orientation, mentoring, job rotation programs, etc.), providing better information about what is expected, better feedback regarding how well those expectations are being met, better tools for providing knowledge and coaching "just-in-time," and better incentives for reaching and maintaining the established performance standards. Additionally, good leadership and management that exhibits and demands competence and understands the value that individual competence makes will help create the organizational climate that fosters individual and corporate learning.

Education and training can be expensive options. Many of the non-training solutions are cheaper and are often much more effective than training, especially if the root cause of the performance problem is lack of good information, feedback, tools, incentives, etc.

\section{Principle 3: To be effective, education and training should be an integrated part of the job and system.}

When lack of knowledge or skill is the real problem, then the overall context of the job should be considered when determining how to fix that problem. Many large organizations have realized that long, schoolhouse-based training programs are ineffective because the learners do not get adequate opportunity to practice, leading to low retention. The context of the schoolhouse may be so different from the real job that many learners are unable to transfer what they learn back on the job. "Just-in-time" helps and coaching, distance and technology-based learning, and structured on-the-job training may be far more effective in teaching many of the concepts and skills needed because these can be integrated into workplace realities.

On the other hand, some complex skills can best be learned in the classroom or laboratory where adequate focus, comfort levels, and "safety nets" can be established to enable learners to progress rapidly through the basics to more advanced levels. In this case, it is important that the learners have the opportunity to apply what they have learned in class to their jobs.

Most importantly, a decision as to when and where to provide learning opportunities and what support systems to employ should be based on a large view of the overall system. Effectiveness is only partly how well learners do at the end of some course. It is also, and more importantly, how much improvement learners evidence on the job, over time, after participating in the learning opportunities. 


\section{Principle 4: Generally speaking, most people can learn most things from most media.}

Years of research repeatedly confirm that learners are amazingly good at adapting to and learning from a wide range of media. This is due to several factors. One fundamental factor is that good instruction probably depends more on its design (the inclusion and ordering of the instructional components or events) than on its delivery format (printed, use of still visuals, video, audio, animation, color, etc.). Design often addresses the essentials and prerequisites of learning more directly than do the types of media used.

Another factor is that learning is an active process requiring attention and mental effort. While some leamers may be ready and want to learn and may be able to do so in spite of the format of the instruction, other less ready or less interested participants may not learn regardless of the format. In other words, when sufficiently motivated and prepared, individuals continue to learn an amazing amount, regardless of the quality and expected effectiveness of the media used; but when interest or motivation are lacking, even the best materials cannot compensate.

\section{Principle 5: In specific cases, media and methods selected can have an enormous impact on efficiency or effectiveness (assuming that design, motivation, and readiness are equal).}

Knowledge regarding which media and methods are most effective under which conditions is evolving at a relatively slow pace. While a large set of intuitively reasonable and empirically ambivalent rules have been assumed for many years, a small number of well-supported rules have recently evolved. These later rules are often derived from the psychology of learning and common sense and represent the state of the art. Many of these rules continue to be refined as important discoveries are made about how learning takes place. Different rules may also apply to different individuals depending on the unique capabilities of each for learning from visual or verbal information.

An example of an empirically-supported rule relates to the use of simulation. Simulation is clearly superior to lecture or even hands-on experience for facilitating problem-solving, troubleshooting and decisionmaking skill development. Research shows that simulations function effectively as advanced organizers in providing learners with an overall awareness of the complexities of a new skill area. Dry labs are often the only safe way to conduct potentially dangerous chemical or physical experiments. Simulations (and visualizations) can help contextualize very abstract and dynamic constructs that are otherwise difficult to grasp. 
Common sense rules that really do not need empirical support include statements like: If practice is required to develop skill, then the print medium should be supplemented with some kind of feedback help to be effective. This help can be provided live (at the time of need) via a telephone help line, class, teleconference, study hall, electronic communication (E-mail, fax), or expert system support, or at a later time via mail or E-mail (i.e., through correspondence programs).

Another common sense rule is that distance learning is typically cheaper than schoolhouse learning when a large number of learners must travel long distances for extended time and be paid their salaries as well. Hewlett-Packard reported that the savings from their first distance learning course paid for the entire system. Obviously, there are some important variables that have to be factored into this kind of an equation. Distance learning advocates are growing in number and influence as more and more companies and individuals are taking advantage of college courses being offered through cable television or satellite networks.

A psychologically-derived rule asserts that case-based learning can be effective because it helps learners derive the concepts and principles to be learned as well as the procedures for action from contextualized instances rather than abstract descriptions. It also promotes experiential learning (learning by doing). The accounting firm of Arthur Anderson and Company has received extensive notice in prominent news and business magazines for its innovative case-based professional training program, developed by artificial intelligence expert Roger Schank and colleagues at Northwestern University.

Other rules that are implicitly included in media selection models relate to the communication channels required by a task and those provided by a delivery medium. For example, when the skill being learned requires visual or auditory information and feedback, methods such as interactive multimedia can be far more effective than printed descriptions of and written feedback on the same activities.

Recent studies indicate that individualized multimedia-delivered instruction is more effective and more efficient than lecture/classroom delivered instruction. This widely supported finding is helping to fuel an important movement in education, from preschool through vocational, college, and graduate levels. 


\section{Principle 6: Media/method selection models (ike any other tools) may be used short- sightedly.}

These selection models are often geared to help decisionmakers examine present needs, given current resources within a relatively short planning window. This is because the models were initially developed for either teachers working within relatively constrained settings or for military designers who were planning and developing single courses of instruction, not an entire curriculum. When an organization is looking for direction in making wide-spread delivery decisions, a selection model should be adapted to fit within the context of the organization's longterm plans and with broad cost-effectiveness and maturity meta-models. Otherwise, the organization will tend to make decisions based on short-term efficiencies or current effectiveness shortfalls rather than long-term cost-effectiveness.

As noted previously, Hewlett-Packard was able to recoup the very substantial costs of creating a distance learning network in delivering their first course. Even within Hewlett-Packard, this undoubtedly required a careful analysis in advance to estimate the value of such a network and to centralize the accounting of the normal costs to empower the training department to invest in the necessary infrastructure that yielded such remarkable returns. For many organizations, however, the return will not be nearly as rapid and therefore much harder to sell. The FAA, for example, in their reported cost-benefit analysis for implementing distance learning, indicated that they will not break even for five years. However, within ten years of starting the system, they project a savings of between $\$ 35-\$ 63$ million.

\section{Principle 7: Focus is shifting from holding instructors accountable to holding learners accountable for aiding the learning process.}

For several decades the holy grail of instructional design was to create "learner-proof" instruction-instruction that works for all learners all the time. The hope was that through enlightened design and careful "revision," course material could be made robust enough to enable mastery level performance. While this approach has been fairly successful in some kinds of technical training, it may be counterproductive in more conceptually-oriented competencies where mastery implies the ability to make difficult judgments, troubleshoot, or organize messy problems. For these latter problems, it may be that the motivation, attention, willingness to apply oneself, curiosity, openness to new learning, and other learner intrinsic variables may be as important as the instructional materials. Some advanced skills can be learned only if the learner is desperately desirous of obtaining those skills. 
Given a motivated student, the goal is then to provide performance support tools that make the job of learning easier by making it easier to find information, consult experts, and access reallife examples. Florida State University's Center for Educational Technology has embarked on the ambitious research project of developing these learner support tools for Florida's public school teachers and students. Given this perspective, entire systems can be seen not as courses, grades or marks on a tracking sheet, but as one large, learner support system. This concept is especially important for $\mathrm{DOE}$ as its mission continues to change and the knowledge and skill demands shift in response to new opportunities and requirements. Organizational theorists claim that the organizations that survive are those able to learn at the individual and organizational level. But becoming a learning organization involves more than having a well-tuned media selection model. It entails fundamental values, attitudes, and ways of viewing the world and each other.

\section{Subtopic 3.2 Adapting a Media-Method Selection Model for DOE}

\section{What would be a good process for DOE to use in evaluating potential effectiveness of} advanced technologies for use DOE-wide, at specific sites, or for specific courses or curricula?

Most media/method selection models are particularly helpful in making design decisions for individual courses being newly developed or revised, especially when technology assistance such as multimedia or distance learning is being considered. The media selection models are rational decisionmaking aids (decision tables or decision trees) and can be used with actual or estimated data to come up with effectiveness-ranked lists of possible alternatives for delivery of courses.

The purpose of a media/method selection model is to help decisionmakers understand and choose between the several possible means of facilitating learning and/or providing instruction. Various characteristics of the current situation (needs) must first be identified, including the final outcomes (what and how well) to be achieved by the learners, the learners' current knowledge and ability levels, and the media, methods, and other resources already available to facilitate learning. Other important cost and efficiency data may be needed to assess trade-offs of efficiency (focusing on reducing costs) and effectiveness (focusing on maximizing the achievement of the specified outcomes, regardless of cost).

Appendix $\mathrm{A}$ includes a media selection guide worksheet. The structure and logic behind this worksheet illustrates many useful media selection models, and represents adaptations made by the United States Air University to a model developed by Hannafin and Peck in 1988. The remainder 
of this subtopic describes this guide and discusses the power and potential hazards of using this or a similar guide.

The guide is essentially a large Multi-Attribute Utility Matrix (MAUM). MAUM is a popular method of helping decisionmakers numerically rate and rank alternatives. The following paragraphs briefly describe how MAUMs work generally and how this particular guide is organized.

Use of MAUMs - To begin with, a problem or class of problems is identified. Then the characteristics of the solutions are considered (e.g., efficiency, effectiveness, cost, safety, schedule delays, amount of change required, acceptability to the current audience, political feasibility). The importance of these attributes is weighted to ensure that proper attention is given to the most critical attributes. Finally, alternatives are generated that might help solve that problem. These can be listed individually or in combinations.

To use the matrix, the decisionmakers must determine the relative ability of each solution to satisfy each attribute. The ratings produced are multiplied by the importance weights to give a cell score. These are added up for each solution. The solution or combination of solutions with the highest scores are examined as the most viable options. Decision-makers use the scores as an aid to help them find the best answer, not as blind formulas that automatically generate the correct answer. This process can help clarify the important issues, many of which may require further evaluation.

Air University Media Guide-This guide is set up to help course designers who want to export courses currently taught in residence (live classrooms) and convert them to some other delivery method. This guide looks only at effectiveness issues-how well various pre-identified solutions match the attributes of a given course being considered for export. This guide does not take into account efficiency issues, therefore recommendations coming from this analysis would need to be checked against spreadsheets of various overall media/method strategies and scenarios. These spreadsheets would contain estimates of number of students, costs, etc.

As a means for identifying the most effective media for exporting specific courses or segments, this tool appears to be well thought out and easy to use. The creators of this guide have already preloaded it with a set of 26 instructional design characteristics (see Appendix A, Media Selection Guide Sheet). These make up the rows in the table. This list can be easily expanded as needed. Many of the characteristics relate closely to one another and could be 
replaced by a higher-level attribute if appropriate. For example, several characteristics relate to self-pacing, learner control, individualization, and scheduling. Another group of characteristics relate to what needs to be represented (displayed) to the learners (i.e., stills, full-motion video, and sound).

To use the guide, an instructor (or analyst/designer) reviews the set of charcteristics and adds or subtracts from the list. The instructor then rates the importance of each of the resulting characteristics. This rating becomes the weight by which the solutions (media alternatives) are multiplied. The creators of this guide identified the solutions that are feasible within the current Air Force audience. These are the columns in the table. This particular table does not show combinations of options, though any given course or set of courses being exported may include a combination of media such as print, videotape, computer-based instruction, and some kind of teleconferencing.

Once the user has made the importance rating, simply multiply that weight by the predesignated capability ratings for each possible solution and add up the columns. In this form, each page has a subtotal and all the subtotals are carried to the last page where a final total for each solution is generated. The guide notes the following: "Consider only those media with the highest scores that are capable of satisfying your critical requirements. Remember, this is not a final decision for DL (Distance Learning) or for a particular medium. Rather, this guide will serve as a basis for further study. In some cases, a mix of media may be appropriate."

Customizing the Guide-DOE would be well-served by adapting and expanding upon this guide. Three recommendations for customizing the guide are:

\section{Recommendation 1: Add front-end logic determining what to teach via exportable methods and what to teach live.}

The United States Research Institute has developed a selection model that helps address these starting issues as well as the attribute of students and instructors working together at the same time (synchronous versus asynchronous). 


\section{Recommendation 2: Expand the scope of the guide in terms of media and methods considered.}

Consider more than which media and methods are exportable. The Air University Guide was specifically built to help choose the best media for exporting existing residence courses. The same model could be expanded (additional solutions and combinations listed) to help designers who are refurbishing existing residence courses or planning new ones to select the best media and methods for those courses as well. Some of the best live courses being taught in America today are live versions of courses created for distance learning.

\section{Recommendation 3: Customize the matrix.}

Customize the criteria for DOE, adding some new ones and removing those that do not apply. Also adjust the "pre-ratings" for various solutions to better reflect the realities within all or part of DOE, and not the generic capabilities of each media.

\section{Subtopic 3.3 Cost-Benefit Analysis for Assessing DOE's ATT Options}

\section{What kind of cost-benefit analysis process should DOE use to evaluate alternate approaches for delivering education and training?}

Cost-benefit analyses require a significant amount of detailed analysis (needs assessmentgenerated) design, and cost and implementation-related information to generate accurate breakeven points and return on investment. Often the media selection tools are used first to eliminate those media that are totally unsuited for some objectives, courses, or curricula. Then a costeffectiveness analysis can be done to compare the set of solutions. The overall goals of the organization, the scope of the changes that are being considered, and the ability to plan and implement strategically-derived solutions will have a major impact on what should be modelled in the cost-benefit studies.

For example, assume that distance learning alternatives survive the initial cuts made through a media selection-they may look very effective. However, the initial costs (infrastructure development of equipment purchasing, facility access, scheduling, coordination, and learning curve of the staff and instructors) are high for most distance learning alternatives. Often it is impossible to show a good return on investment or cost-benefit ratio for a small group of individuals or small number of courses if these upfront costs have to be directly borne by a few 
small programs. If, on the other hand, an organization has already paid for these capabilities or is planning wide-spread use, it may be relatively easy to show significant economies through the use of these advanced technologies.

As noted above, one international high-tech company was able to recoup all infrastructure costs through the savings generated by reduced travel costs (both airfare and shorter training time required by not having to travel) the first time the system was used. Another dramatic example of a positive cost-benefit study is a proposed distance learning network to be built and used by the FAA. According to the analysis, one scenario shows the system running in the red for three years before costing less than the currently implemented alternatives. However, once the initial investment costs have been paid back by savings, the accumulated savings will amount to an estimated $\$ 34,601,560$ just ten years after the start of the project. A second scenario involving wider use of the network shows an overall savings of $\$ 62,864,491$ during that same ten year period.

These "what-if" exercises are extremely important and can help justify and motivate important changes and significant savings. However, they depend on a number of important assumptions. Too often, these "what-if" exercises conducted for the adoption of advanced training media tell only half-truths or are overly optimistic about startup costs (and difficulties), usage rates, development costs, and operating costs. Even when these numbers are sound, there is another whole class of strategic variables that must not be ignored.

The following are recommendations for DOE to apply the principles of cost-benefit analysis profitably.

\section{Recommendation 1: Add estimated cost data per media and other needs-analysis- generated data, such as expected number of students per site per year, acceptance and usability of various media options, etc.}

This cost-benefit modeling would need to allow for several strategic scenarios to envisage wide-scale adoption of various distance learning technologies. With such scenarios in place, it is possible to amortize the cost of the infrastructure across a large number of courses. Without such scenarios, the cost of purchasing interactive teleconferencing or multimedia equipment for just one project becomes prohibitive. 


\section{Recommendation 2: Provide computational assistance and database storage of and access to information needed.}

Create system outlines, databases and spreadsheets to aid the inputting, sorting and computation of media selection options and cost-benefit analyses. Feed the databases with as much relevant data as can be obtained. Where needs-analysis data have not been developed, populate the database with estimates based on expert judgment, noting the source of the data.

\section{Recommendation 3: Eventually construct two levels of cost-benefit models.}

The first model should be easy to use and intuitively powerful. This model should support conceptual brainstorming and rapid prototyping/evaluation sessions. This "approximation" may be sufficient for strategic planning purposes. The second model should be much more detailed, and use itemized and accurate data to produce solid cost-benefit analyses. The work required to acquire the data for the second model is probably 10 to 100 times greater but may eventually be needed before strategic plans can be moved to tactical or logistic plans.

\section{Subtopic 3.4 Strategic Tools to Assess DOE's Acceptance and Readiness for ATT}

What strategic tools or models are available that could help DOE develop progressive, yet realistic, strategic plans for using advanced technology?

This subtopic presents a general model, adapted from quality management, for helping organizations assess their current level of acceptance readiness for advanced technologies. The requirements and use of the model are described in the following pages.

\section{Requirements for a Strategic Model}

There are five requirements for a comprehensive model of systems design and problemsolving for educational and training purposes:

1. The model must help solve long-term problems but also provide specific short-term guidance for progressing from step to step. The model should have strategic, tactical, and logistical prescriptive power. 
2. The model must incorporate the best aspects (proven, acceptable, and applicable) of a wide range of related disciplines including systems thinking and instructional technology, total quality management, management science, organizational development (particularly change management), and learning and social psychology.

3. The model must provide a means for assessing both the specific performance needs of the organization and the current status of the overall organization in terms of its readiness to accept and use advanced technology solutions.

4. The model must provide a means for assessing the current status of the group responsible for coordinating, integrating, and possibly providing education and training within the organization.

5. The model must help decisionmakers of the organization and of the education and training group understand why things are as they are, and what changes may be effective in changing the status.

\section{The Technology Cure-All}

Most Americans respect technology. The whole concept of progress has been linked to technology to the point that technology has become an end in itself and often a panacea offered to solve a big problem.

A good illustration of the appropriate use of technology is the use of Computer Aided Software Engineering (CASE) tools in software engineering. A software company at Level 1 sees that its competition at Level 3 is using high-end CASE tools extensively. Combined with the strong advertising of the vendors, this makes the purchase of CASE tools a tempting proposition. But as Edward Yourdon, a leading computer programming expert, points out in The Decline and Fall of the American Programmer (1992), most companies that succumb to this approach simply waste their money because they cannot support the tools; their organization, culture, and infrastructure are not sufficiently developed to make the best use of the technology. The tools end up as "shelfware" and the net result is a small step backward because of the added resistance to using these tools in the future.

An extensive literature base is evolving in the areas of quality and change management. The key principles discovered in these fields have been applied in many areas with notable success. 
While many of the principles were first applied to manufacturing and operations, often with dramatic results, recent movements have applied them to service industries such as hotel management, software development, military and vocational training, vocational education, and health care. Application of these principles to higher education, management training, and most other training, however, has hardly begun. Many of these principles would serve as the fundamentals for a model for the appropriate usage of technology. Such a model should help managers of training systems understand their needs, the strengths and weaknesses of each technology, and the readiness of their organizations for certain types of solutions. A model-based approach needs to provide help to planners and decisionmakers at several different levels: strategic, tactical, and logistical. One of the most important benefits of a model-based approach is that it puts technology use into perspective, without diminishing its value.

\section{Usefulness of Existing Models}

The media-method selection models reviewed in the previous subtopics, while useful, tend to be primarily tactical and are heavier on prescription than on assessment-they provide little strategic guidance and no logistical help. In short, they need to be expanded or elaborated to help organizations better assess their needs and situation, estimate their specific costs, and understand trade-offs. They also need to be broadened to include more fundamental organizational readiness and change-related considerations.

An example of a system with the robustness sought for in education and training is the software "Capabilities Maturity Model (CMM)." It was developed in the early 90's by Humpheries and his colleagues at the Software Engineering Institute (SEI) as a maturity assessment program for software. Humpheries, et al., borrowed heavily from Crosby, a prominent proponent of Total Quality Management.

In the late 1980's, Crosby developed a model for organizations to use in assessing their overall maturity, especially in terms of quality. He identified five levels of maturity and a corresponding set of questions and criteria that could be used by organizations to assess their current level. The fundamental principle underlying this model is that growth is phased and sequential. If an organization is at a beginning stage of quality, specific changes must be made and organizational learning, attitudes, and processes must become internalized before the organization can reach the next level. If these skills and systems are not acquired sequentially, attempts to move ahead are thwarted and often backfire. It is essentially impossible to jump levels or skip steps. 


\section{The Power of Maturity Models}

Maturity is a concept borrowed from Total Quality Management and refers to the level (given several pre-defined levels) at which an organization currently operates. The purpose of assessing the maturity of any given organization is to establish practical short-term plans for moving the organization to the next level of maturity and to prioritize activities that will leverage that progression to the greatest extent. According to the fundamental assumptions of this approach, a Level 1 organization needs to move to Level 2 before attempting to go to Level 3. The concept reasons that without the infrastructure, cultural change, and management commitment in place at Level 2 , the necessary organizational resources, commitment, vision, and culture simply will not support a viable Level 3 effort. That is, an organization must learn to walk before learning to run.

The maturity model approach has some strong implications for managers who work in a crisis-oriented environment, where problems evolve for decades and then, because of a highly visible event or personnel changes at the top, the organization suddenly desires to move from Level 1 to Level 3 or 4 in one or two years. The maturity model makes the impossibility of such demands crystal clear.

A corollary assumption is that the larger the organization, the longer it takes to move from level to level because of the overall inertia, communication demands, and plurality of cultures. All of these conditions apply to the current Department of Energy training system.

\section{The General Acceptance and Readiness for Technology Heuristic (GARTH) Model}

Because no model was found that met all the requirements described above, it was necessary to create one. The approach adopted here has been to start with the software Capabilities Maturity Model and reshape it into a General Acceptance and Readiness for Technology Heuristic (GARTH) Model. The synthesis is new and more a matter of best professional judgment than "validated" empiricism. Certainly further work validating the meta-model and the various submodels would refine the insights and recommendations. The description of the model has been included to allow decisionmakers to review the assumptions, logic, and reasonableness underneath the strategic, tactical and next-step recommendations made. Because of its general nature, GARTH can assess overall organizational maturity and has numerous implications for strategic planning as well as for assessing an organization's readiness for technology, the focus of this study. 


\section{The General Acceptance and Readiness for Technology Heuristic (GARTH) Model}

Defined.

Table 29 shows the original five levels of maturity for software engineering (right side of the table) compared to the five levels of maturity for organizations which are developing or implementing training systems (the left side). Of particular value are the analogous characteristics and rules that can be drawn from the software engineering model and applied to training systems in identifying the key actions needed to advance to the next level and the lessons learned (see the last two columns of the table).

Table 30 further defines the five aspects of the proposed GARTH model: planning activities, information paradigm, quality focus, training focus, and technology applications. For each aspect, a few words describe what would be expected at each level. Each level retains and stretches the positive features of lower levels while shedding more and more of the constraining or self-limiting attributes of the organization. Some changes from one level to another require fundamental paradigm shifts and possibly a substantial technology investment. However, these shifts and investments are undertaken knowingly and with some idea of the expected outcome.

The focus of the planning activities is different for each level. The planning horizon becomes longer and longer, with a tactical goal of process control, order, and uniformity driving Level 2, and strategic goals starting in drive Levels 3 and above.

An improved information paradigm is supported at each successive level, moving from isolated islands of data to whole continents of meaningful and useful information. The use of the knowledge increases in importance from cataloging at Level 2, to understanding and problemsolving at Level 3 , to even more effective problem-solving at Level 4 , to entire reconceptualization of systems at Level 5 .

The focus of quality improvement efforts broaden from obtaining control of the process and optimizing efficiency through efforts at cataloging, eliminating redundancy, promoting sharing, and establishing a well-tuned infrastructure in Level 2, to locking in customer (stakeholder) needs and product quality at Level 3 , to unleashing the positive emotional energy of the work force through team and individual empowerment at Level 4. It is hypothesized that training organizations at Level 5 will so thoroughly merge their quality, training, and technology efforts that these three aspects become indistinguishable. 
The organizationally supplied training focus changes from compliance-based training at Level 1, to establishing standards for professional competence (i.e., qualification and certification standards) at Level 2, to looking at worker development over the entire lifetime of employment, emphasizing worker ownership and self-development as well as career progression at Level 3. Also part of Level 3 is an extensive effort to collaborate with other similar organizations to offset the cost of training development and to allow for faster and less painful implementation of technologies based on industry lessons learned. Organizations reaching Level 4 are focusing on performance enhancement as an integrated area and have combined resources from numerous previously separate domains to solve and prevent performance problems.

Technology supporting learning and training progresses through several levels as follows:

Level 1 - Traditional teacher-led nontechnology supported classroom.

Level 2 - Uneven and localized technology assisted learning using multimedia and limited participation in distance learning.

Level 3 - System-wide availability and wide-spread use of distance learning technologies, network-delivered multi-media, and online information services.

Level 4 - Intelligent support (tutoring, expert coaching and advisory, case-based reasoning, knowledge retrieval, and workbench) systems that provide help just-in-time and support collaboration.

Level 5 - Invisible tools that are intergrated with the cross-functional work/learning environments (futuristic).

It should be emphasized that while many outstanding distance learning and multimedia courses emerge and flourish as part of Level 2, at Level 3 they become fully orchestrated (integrated and coordinated) and widely-accepted across the entire system. Group-based distance learning (interactive televideo conferences) becomes commonplace as does network-provided multimedia-based individualized instruction.

Moving from Level 3 to Level 4 is a major shift because it requires a fundamental paradigm change. Instead of looking at training and development as a separate, supporting function within the organization, it becomes an almost invisible, fully integrated function that is merged with 
electronic performance support tools to enhance job performance and minimize expense. Training as a separate function may no longer exist though plenty of learning takes place (some still in classroom settings). Now performance and capability enhancement is promoted through all aspects of the job.

In summary, to improve its training system, an organization needs to assess its current position, then make the changes needed to move to the next higher level. The vision of being a Level 3,4 , or 5 organization is very important to propel change. The immediate goal, however, should always be to move to the next higher level. 


\begin{tabular}{|c|c|c|c|c|c|}
\hline 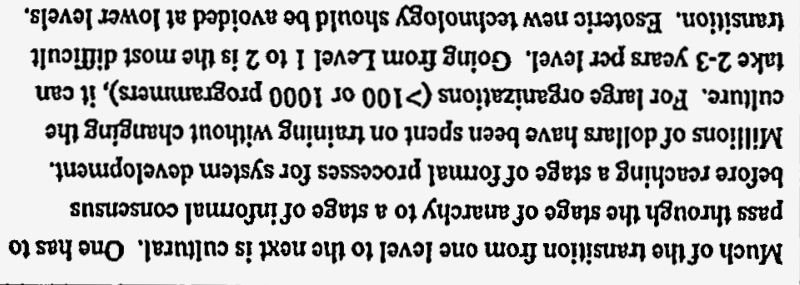 & 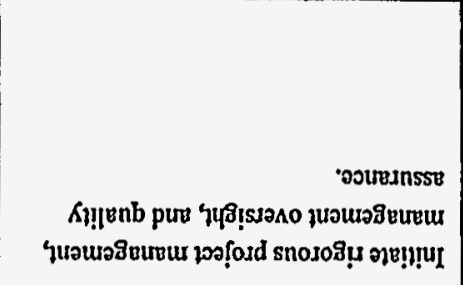 & 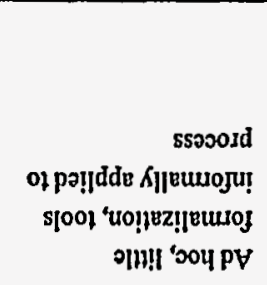 & |घ!!̣प & 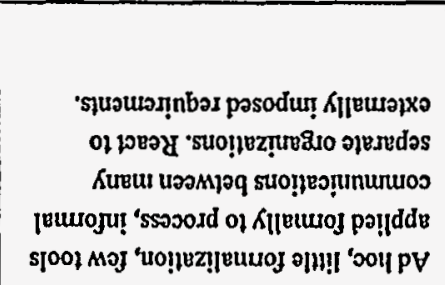 & 1 \\
\hline 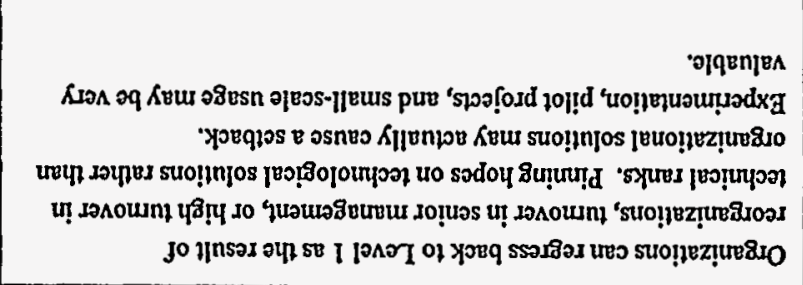 & 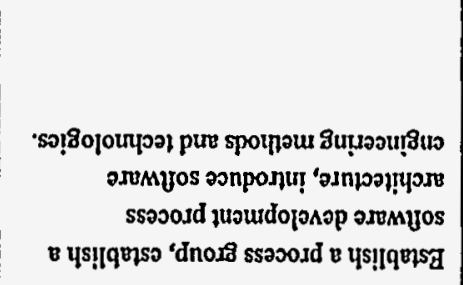 & 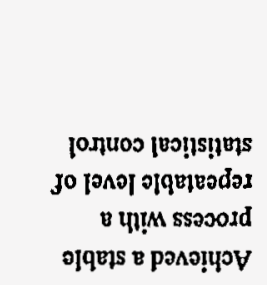 & $\begin{array}{l}\text { गรqघiвodəy } \\
\tau\end{array}$ & 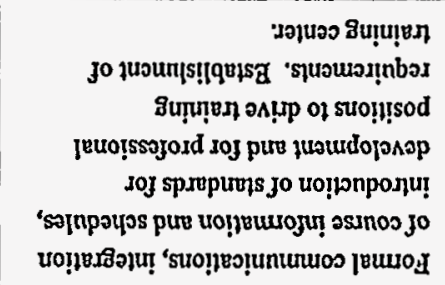 & 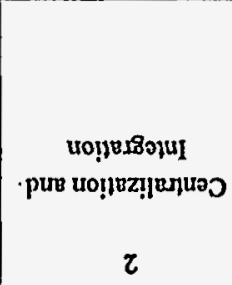 \\
\hline 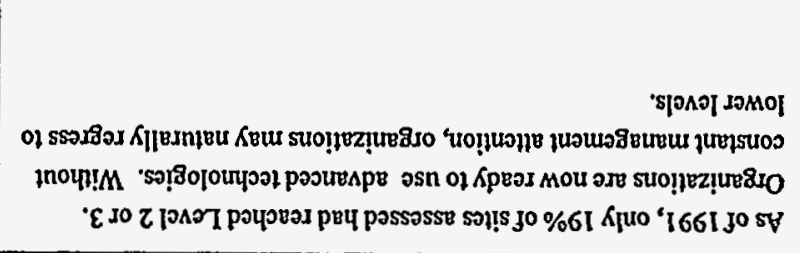 & 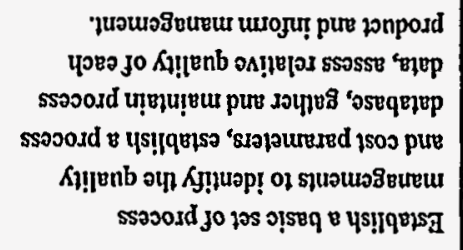 & 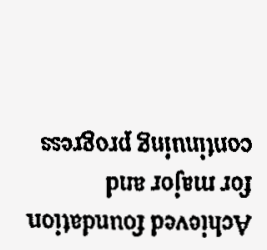 & $\begin{array}{l}\text { pounjed } \\
\varepsilon\end{array}$ & 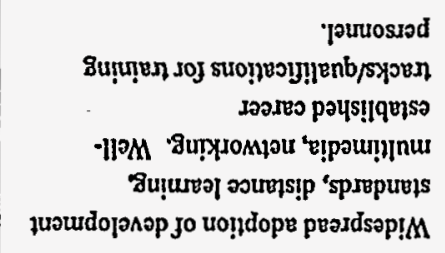 & 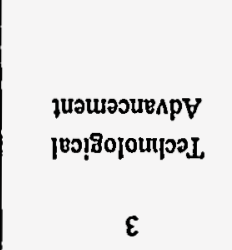 \\
\hline 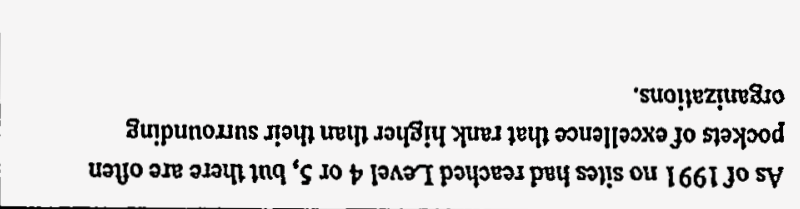 & 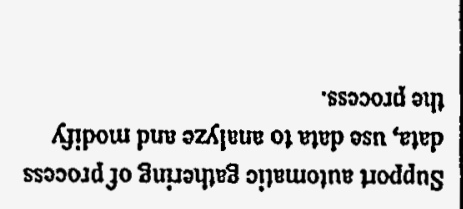 & 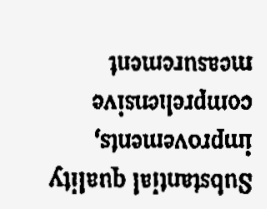 & poseuren & 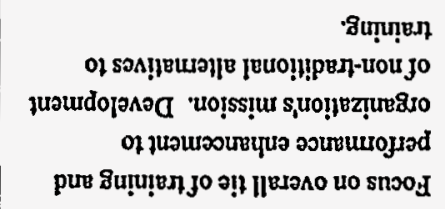 & 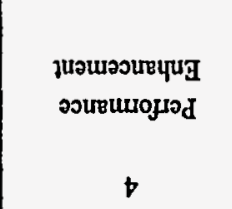 \\
\hline 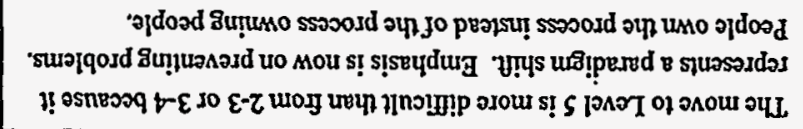 & 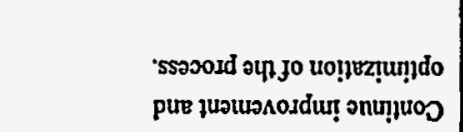 & 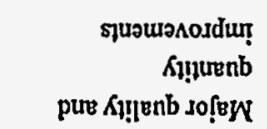 & $\begin{array}{l}\text { pazțuntdo } \\
\qquad\end{array}$ & 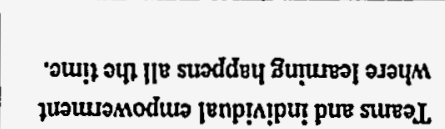 & $\begin{array}{c}\text { PIPOM MON } \\
\qquad\end{array}$ \\
\hline (1. & 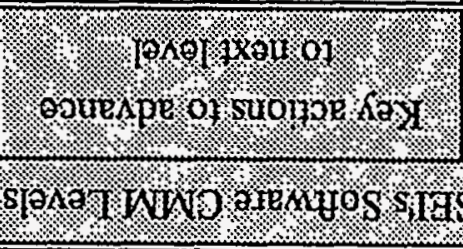 & 81010100\% & (1) & 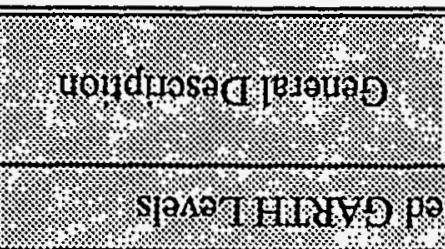 & 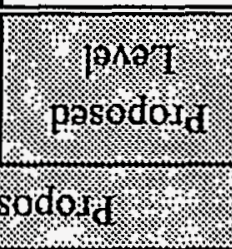 \\
\hline
\end{tabular}

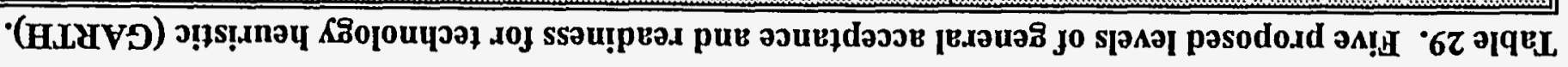


Table 30. Characteristics of general acceptance and readiness for technology heuristic (GARTH).

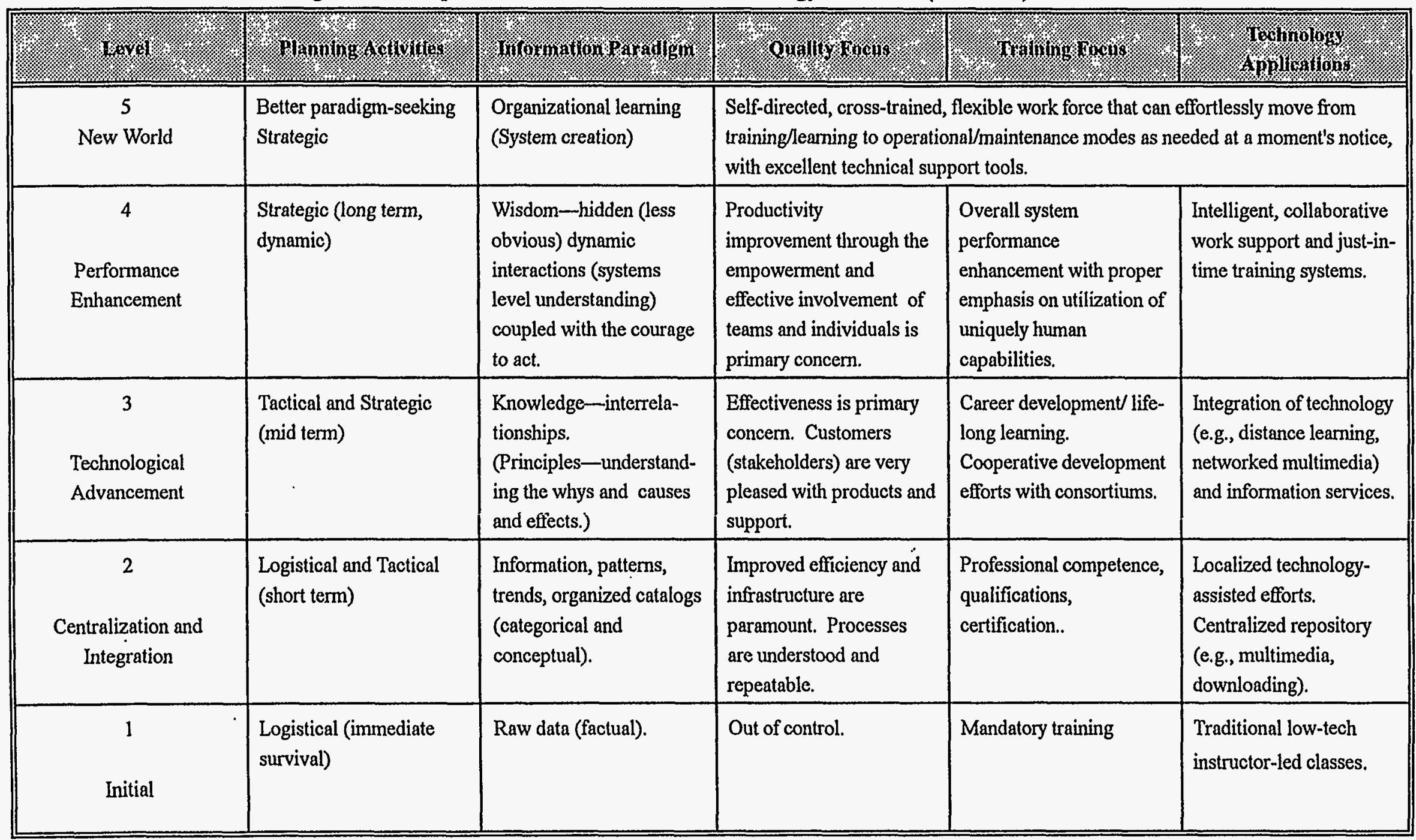




\section{Subtopic 3.5 Generic Guidelines for Establishing a}

\section{Centralized Training Function}

Given the data collected, lessons learned, methods, processes, and models studied, what guidelines can be stated for creating a centralized training function? What functions phases might serve as a strategic plan for a centralized training function or center?

\section{Factors to Consider When Centralizing Training}

The four factors to consider in assessing the type and degree of centralization needed by an organization are:

Factor 1: Expected Longevity of Program, Level of Emphasis, and Type and Size of Audience

When a training program needs to be put in place very quickly, has a high level of emphasis, or is targeted for a large number of students, centralization should be beneifical.

Creating a virtual university appeared to be an excellent method for meeting the requirements set forth by Congress to upgrade the contracting and materiel acquisition skills of military and key military contractor personnel in a short period. Within months of the money becoming available, courses were offered without the construction of a single building or office. Centralization of funds makes it possible for complete cost-effectiveness analysis with almost no additional overhead cost for gathering or analyzing that data. A small staff was able to find and contract a complete curriculum in record time and yet not leave behind massive buildings should the funding be cut or if the initial enrollment declines.

On the other hand, the FBI, which owns all of its own facilities, has been able to effectively utilize them by providing space in their classes to other agencies and other friendly governments or leasing the facilities at times when they are not being used by the FBI. Many of these facilities would be very difficult to replicate elsewhere (labs, firing ranges, mock city, etc.). The residence nature of the facility also helps serve an important socialization and indoctrination purpose. 


\section{Factor 2: Overall Maturity of the Organization}

This factor may be one of the most important considerations in deciding upon the type and degree of centralization. If an organization is in chaos, centralization may be required to provide the discipline, vision, mechanisms, and resources needed for it to progress. And yet, once order has been established, it is likely that further growth will be associated with greater and greater decentralization, though this may vary depending on the needs and mission of the organization. It is possible that standard-setting, and policy and procedural centralization are the minimum requirements for moving beyond chaos.

\section{Factor 3: Employee Characteristics Including Learning Preferences, Motivations, and Geographical Locations}

Decentralized training facilities and methods such as distance learning and multimedia may be too advanced for an intended audience (though this may change as a new generation of workers comes to the job). Fear of technology still afflicts many in the work force. Those raised in traditional settings, like a classroom lecture environment, may prefer these methods over more interactive multimedia simply because it preserves their world-view. In many cases, organizations have been able to help their employees break through these barriers and take advantage of the improved convenience and sometimes improved cost-effectiveness of advanced technologies.

Centralization is not without its advantages, such as easier recordkeeping, and improved quality control and security (i.e., of testing). However, many organizations are finding that the centralization of analysis, design, development, and coordination is far more productive than the centralization of delivery of instruction.

\section{Factor 4: Content Objectives-What Is Being Learned and How Well Must It Be learned?}

If the objective is to acculturate someone into an organization, centralization of delivery may be imperative. The learner needs to be immersed in the culture, to see the values portrayed by instructors and other role models, and to become attuned to the symbols of the organization. Notable examples are the military and Arthur Andersen and Company.

If the need is for uniformity and consistency of vork force, centralization of the qualification standards is essential. These must be derived from real requirements and needs analysis, a tedious effort that is usually short-changed when decentralized. Centralization can lead to efficiencies as 
existing materials that support the qualifications are accumulated and evaluated or as new materials are developed through assignment, coordination, or syndication.

Given large groups of potential learners and skills that can be effectively taught via multimedia, centralized development or coordination may be the only way to create the capital necessary to create these expensive courses. If the content needs to be classroom-based, distance learning options offer a certain amount of centralization.

If the need is to foster diversity, independence, and creativity in problem-solving, both centralization and decentralization have their strengths and weaknesses. Centralization can thwart creativity because it can become insensitive and monolithic. On the other hand, the resources for in-depth development may not be available without centralizing and concentrating the money, talent, and leamers.

Finally, the need for physical fidelity may justify the centralization of training in establishing laboratories or simulator centers (e.g., FBI, NRC, FAA, Air Force, nuclear power industry).

\section{General Comments about Centralization}

From a pragmatic viewpoint, centralization may be beneficial to a training organization, given particular needs, conditions, and desired outcomes. The organizations surveyed evidenced a wide range of centralization, many of which were unexpected or unique. It is clear from the survey that one model or uniform description of centralization will not work for all organizations. Organizations known to promote decentralization in one sense are often the most centralized in another. Clearly, technology can help organizations achieve a needed degree of centralization in access, development and locus of control without forcing co-location (except where absolutely required) or massive expenditures on classroom buildings or on travel. Technology can help promote the strengths of centralization without forcing the onerous burden entailed by its disadvantages.

Finally, there is some evidence that a fundamental amount of centralization is needed by any organization seeking to rise above chaos. At later stages of maturity, this centralization may change colors to become distribution, coordination or even facilitation but it is only possible because some kind of organizational central nervous system has been developed. It is probable that the term "centralization" ought to be replaced with the term "order" or "organization" and that, contrary to educational rhetoric, the opposite of centralization is not decentralization but 
rather chaos, anarchy or confusion, with decentralization being simply a unique manifestation of mature centralization.

\section{Generic Functions of a Central Training Organization or Training Center}

A strategic plan needs to be fairly high-level and general. It creates the broad dimensions and long-term framework within which more detailed tactical and logistical planning is accomplished. The key dimensions selected for this prototype strategic plan are training and coordination functions along one dimension and time (in phases) along the other. ${ }^{6}$ The most important suggested functions include:

\section{Function 1: External Resources}

Coordinate education and learning resources outside the parent organization. Foster collaborative development efforts with other organizations that share similar training and development needs. Become a clearinghouse for identifying resources that are available externally and for gathering and sharing information regarding the costs and perceived value of these resources.

\section{Function 2: Organization-wide Training Schedule}

Coordinate the scheduling of training across the entire organization. Serve as a central source of information to which all can turn for a complete listing of generic training (e.g., training which is not site or sub-organization specific.) Even schedules for non-generic training may be sent to central training for the purpose of sharing it as needed with any inquirers from other sites or sub-organizations.

\section{Function 3: Internal Resources}

Inventory and distribute learning materials. Serve as a clearinghouse for internally developed or delivered training, especially training developed by other than the central training function.

\footnotetext{
${ }^{6}$ Much of the basis for this prototype strategic plan for a training center was derived from discussions held by the Energy Technical Training Center (ETTC) working group during the summer of 1994.
} 


\section{Function 4: Quality Assurance}

Evaluate/provide feedback or upgrade existing materials. Take the materials gathered for the internal resources (clearinghouse and dissemination) function and apply quality standards to determine whether the materials are in fact suitable for release across the whole organization. Otherwise, the clearinghouse function becomes partially one of garbage-in garbage-out, and the overall credibility and perceived usefulness of the centralized training organization slips.

\section{Function 5: Systems Application}

Analyze needs, design, develop/coordinate development of new courses. As existing courses are inventoried and evaluated in the two functions above, they are compared against the results of needs assessments and design which is the foundation of this function. Where there are major deficiencies (courses/modules that don't work or do not help the learners develop specified competencies or meet general mandatory training requirements), the central training organization is in the ideal position to develop or contract out development of the instructional material. For large organizations with several local training organizations, it may be possible to select the most qualified local training organization for each course or module to be developed and contract internally for the development. These local organizations can perform the work themselves or supervise contractors.

\section{Function 6: Instructional Delivery}

Deliver instruction. Present classroom instruction where applicable in a central location or rotate it through various sites or convenient third-party locations.

\section{Function 7: Advanced Technology}

Identify and introduce advanced training technologies and methodologies. Establish standards and platform standardization to ensure operability of multimedia and distance learning across the entire organization. Where appropriate, replace live instruction with other forms of multimedia and computer-based training, and network-based or distance learning-based methods. Select projects that will serve as good test cases to enable the entire organization to become more familiar with ATT. 


\section{Function 8: Training Assistance}

Coordinate training assistance requests. Provide expertise and help in person (as resources permit), at a distance, or identify and coordinate the creation of assistance teams and visits drawn from throughout the entire organization.

Not shown in the table but subsumed under several of the other functions including Systematic Approach to Training (SAT), Delivery, and Advanced Technology are important staff functions to establish and use the media-method selection models, cost-benefit analyses, and strategic planning discussed previously in this part of the study. Even more important, and also not included, is the vital function of serving as an advisor to the highest level TQM councils that make personnel and organizational plans. The central training organization can thus become an agent for ensuring follow through and consistency as well as for promoting cultural change. An excellent example of a center that has successfully performed this function is Motorola University, where the President has been able to promote rapid changes in the organization through the talents and directed efforts of the University.

\section{Generic Phases in Establishing a Central Training Organization or Training Center}

Phases constitute the second dimension and will be determined by funding level, current level of acceptance and readiness (as per GARTH), and the organization's overall plans and needs. The phases in the prototype plan are projected at 12 to 24 months each (these are not fixed numbers).

Note also that the establishment of a successful center appears to require a system at or approaching Level 2 because of the need to centralize many functions and integrate a large number of semi-autonomous parts. If an organization is not already in the process of moving toward Level 2, GARTH would predict that going with a center now, without establishing better internal coordination, integration, and process uniformity, would be a mistake because it might fail. Given an organization's foundational work in establishing standards and in integrating and coordinating all kinds of information and resources, it is possible that the establishment of the center could accelerate and help consolidate the movement to Level 2.

As shown in Table 31, the center would evolve from coordinating, disseminating, and teaching live courses to extensive delivery of course material for individualized multimedia-based learning or for group-based distance learning via satellite, phone lines, or the information superhighway. Experimental and focused use of these technologies is appropriate for Level 2, but 
is probably premature for widespread use until the organization is at Level 3. This building process is actually part of the proposed sequence shown in Table 31 . As the organization progresses, the central training organization will be able to shift from a mass-market oriented technical training approach to a performance improvement, resource providing, competence and personal skills development orientation. Tools are made available in the workplace to provide knowledge and training just-in-time. Learners are now empowered to design and implement their tailored development plans using the resources of the organization and external connections to progress.

Not called out in the table or previously mentioned, oversight of the function should be provided by stakeholders from all parts of the organization who are vitally affected by the success or failure of the center. Also, panels of experts can be used effectively to help provide guidance and recommendations for external involvement, streamlined methods, and appropriate applications of ATT. 
Table 31. Prototypical functions by phase for a training center.

\begin{tabular}{|c|c|c|c|c|c|c|c|c|}
\hline $\begin{array}{l}\text { Function- } \rightarrow \\
\text { Phase } \\
1 \\
1 \\
\mathrm{~V} \\
\text { (not GARTH level) }\end{array}$ & $\begin{array}{l}\text { RXTERNAL } \\
\text { RESOURCES } \\
\text { Coordinate education } \\
\text { and learning } \\
\text { resources oulside the } \\
\text { organization }\end{array}$ & $\begin{array}{l}\text { INTERNAL } \\
\text { RESOURCES } \\
\text { Inventory and } \\
\text { distributc learning } \\
\text { materials }\end{array}$ & $\begin{array}{l}\text { ORGANIZATION- } \\
\text { WIDE SCFIEDULE } \\
\text { Coordinate the } \\
\text { scheduling of training } \\
\text { across entirc } \\
\text { organization }\end{array}$ & $\begin{array}{l}\text { QUALTTY } \\
\text { ASSURANCE } \\
\text { Evaluate/ provide } \\
\text { feedback or upgrade } \\
\text { existing materials }\end{array}$ & $\begin{array}{l}\text { SYSTEMS } \\
\text { APPLCATION } \\
\text { Analyze needs, } \\
\text { design, develop/ } \\
\text { coordinate } \\
\text { development of new } \\
\text { courses }\end{array}$ & $\begin{array}{l}\text { INSTRUCTIONAL } \\
\text { DELIVERY } \\
\text { Deliver instruction }\end{array}$ & $\begin{array}{l}\text { ADVANCED } \\
\text { TECKENOLOCY } \\
\text { Identify and introduce } \\
\text { advanced training } \\
\text { technologies and } \\
\text { methodologies }\end{array}$ & $\begin{array}{l}\text { TRAINING } \\
\text { ASSISTANCE } \\
\text { Coordinate training } \\
\text { assistance requests }\end{array}$ \\
\hline (Year 1$)$ & $\begin{array}{l}\text { Merge into } \\
\text { internal/external } \\
\text { training organizations }\end{array}$ & $\begin{array}{l}\text { Identify existing } \\
\text { courses, instructors, } \\
\text { facilities and } \\
\text { hardware } \\
\text { Collect existing } \\
\text { course materials } \\
\text { Expand and fine-tune } \\
\text { course catalog }\end{array}$ & $\begin{array}{l}\text { Integrate field } \\
\text { training schedules } \\
\text { Publish organization- } \\
\text { wide training } \\
\text { schedule }\end{array}$ & $\begin{array}{l}\text { Identify applicable } \\
\text { standards for } \\
\text { evaluating courses } \\
\text { and other leaming } \\
\text { tools }\end{array}$ & $\begin{array}{l}\text { Establish needs } \\
\text { assessment } \\
\text { methodology } \\
\text { Consider watchdog } \\
\text { committee findings } \\
\text { and other } \\
\text { requirements } \\
\text { Identify courses for } \\
\text { development }\end{array}$ & $\begin{array}{l}\text { Deliver existing } \\
\text { courses (technical) }\end{array}$ & $\begin{array}{l}\text { Explore/utilize } \\
\text { distance leaming for } \\
\text { delivery of some } \\
\text { courses }\end{array}$ & $\begin{array}{l}\text { Conduct at least } 3 \\
\text { assist visits }\end{array}$ \\
\hline $\begin{array}{l}\text { II } \\
\text { (Years 2-3) } \\
\text { In addition to } \\
\text { continuing on-going } \\
\text { activitics from Phase } \\
\text { I. }\end{array}$ & $\begin{array}{l}\text { Identify and evaluate } \\
\text { various resources in } \\
\text { academia and the } \\
\text { nationai iearning } \\
\text { community for use by } \\
\text { the entire } \\
\text { organization } \\
\text { Disseminate } \\
\text { information about } \\
\text { external resources } \\
\text { Collaboratively } \\
\text { identify one or more } \\
\text { courses to co-develop }\end{array}$ & $\begin{array}{l}\text { Pilot the mass } \\
\text { distribution of } \\
\text { materials using } \\
\text { ciectronic networks } \\
\text { (i.e., Intemet) } \\
\text { Implement electronic } \\
\text { course catalog using } \\
\text { the electronic } \\
\text { networks }\end{array}$ & $\begin{array}{l}\text { Implement electronic } \\
\text { registration system }\end{array}$ & $\begin{array}{l}\text { Start validating and } \\
\text { upgrading existing } \\
\text { courses to the } \\
\text { established standards }\end{array}$ & $\begin{array}{l}\text { Cany out needs } \\
\text { assessment and } \\
\text { identify widely } \\
\text { appticable mandatory } \\
\text { training } \\
\text { Establish priorities } \\
\text { for training to be } \\
\text { provided at a central } \\
\text { location } \\
\text { Identify further } \\
\text { courses to be } \\
\text { developed } \\
\text { Develop and pilot } \\
\text { courses (identified in } \\
\text { Phase II) }\end{array}$ & $\begin{array}{l}\text { Expand curriculum } \\
\text { offered by center }\end{array}$ & $\begin{array}{l}\text { Deliver leaming at a } \\
\text { distance via } \\
\text { interactive TV or } \\
\text { multimedia to and } \\
\text { from sites }\end{array}$ & $\begin{array}{l}\text { Continue conducting } \\
\text { assist visits }\end{array}$ \\
\hline
\end{tabular}




\begin{tabular}{|c|c|c|c|c|c|c|c|c|}
\hline $\begin{array}{l}\text { Function } \rightarrow \\
\text { Phase } \\
1 \\
1 \\
\mathrm{~V} \\
\text { (not GARTH level) }\end{array}$ & $\begin{array}{l}\text { EXTERNAL } \\
\text { RESOURCES } \\
\text { Coordinate education } \\
\text { and leaming } \\
\text { resources outside the } \\
\text { onganization }\end{array}$ & $\begin{array}{l}\text { INTERNAL } \\
\text { RESOURCES } \\
\text { Inventory and } \\
\text { distribute leaming } \\
\text { materials }\end{array}$ & $\begin{array}{l}\text { ORGANIZATION- } \\
\text { WDE SCHEDULE } \\
\text { Coordinate the } \\
\text { scheduling of training } \\
\text { across entire } \\
\text { organization }\end{array}$ & $\begin{array}{l}\text { QUALITY } \\
\text { ASSURANCE } \\
\text { Evaluate/ provide } \\
\text { feedback or upgrade } \\
\text { existing materials }\end{array}$ & $\begin{array}{l}\text { SYSTEMS } \\
\text { APPLICATION } \\
\text { Analyze needs, } \\
\text { design, develop/ } \\
\text { coordinate } \\
\text { development of new } \\
\text { courses }\end{array}$ & $\begin{array}{l}\text { INSTRUCTIONAL } \\
\text { DELIVERY } \\
\text { Deliver instruction }\end{array}$ & $\begin{array}{l}\text { ADVANCED } \\
\text { TECHINOLOGY } \\
\text { Identify and introduce } \\
\text { sdvanced training } \\
\text { technologies and } \\
\text { methodologies }\end{array}$ & $\begin{array}{l}\text { TRAINING } \\
\text { ASSISTANCE } \\
\text { Coordinate training } \\
\text { assistance requests }\end{array}$ \\
\hline $\begin{array}{l}\text { III } \\
\text { (Years 4-5) } \\
\text { In addition to } \\
\text { continuing on-going } \\
\text { sctivities from Phase } \\
\text { II. }\end{array}$ & $\begin{array}{l}\text { Continue surveying } \\
\text { evaluating and } \\
\text { collaborating with } \\
\text { external sources of } \\
\text { learning } \\
\text { Initiate accreditation/ } \\
\text { certification efforts }\end{array}$ & $\begin{array}{l}\text { Maintain online } \\
\text { catalog and access to } \\
\text { materials/resources } \\
\text { Integrale with other } \\
\text { information systems } \\
\text { to sccomplish the } \\
\text { organization's } \\
\text { requirements }\end{array}$ & $\begin{array}{l}\text { Integrate performance } \\
\text { measurements to } \\
\text { establish uniformity } \\
\text { across field sites }\end{array}$ & $\begin{array}{l}\text { Continue validating } \\
\text { upgrading existing } \\
\text { leaming materials }\end{array}$ & $\begin{array}{l}\text { Develop cost- } \\
\text { effectiveness models }\end{array}$ & $\begin{array}{l}\text { Continue expanding } \\
\text { the delivery of } \\
\text { training }\end{array}$ & $\begin{array}{l}\text { Continue the } \\
\text { judicious and cost- } \\
\text { effective use of } \\
\text { distance learning and } \\
\text { multimedis }\end{array}$ & $\begin{array}{l}\text { Continue providing } \\
\text { assist visits }\end{array}$ \\
\hline $\begin{array}{l}\text { IV } \\
\text { (Years 6.10) } \\
\text { In addition to } \\
\text { continuing activities } \\
\text { from Phase III }\end{array}$ & $\begin{array}{l}\text { Continue surveying } \\
\text { evaluating and } \\
\text { collaborating with } \\
\text { external sources of } \\
\text { leaming } \\
\text { Complete } \\
\text { accreditation/ } \\
\text { certification efforts }\end{array}$ & $\begin{array}{l}\text { Maintain online } \\
\text { catalog and access to } \\
\text { materials/resources }\end{array}$ & $\begin{array}{l}\text { Continue supporting } \\
\text { the integration of } \\
\text { training across all the } \\
\text { field siles }\end{array}$ & $\begin{array}{l}\text { Validate and upgrade } \\
\text { new courses as they } \\
\text { are become available } \\
\text { within the system }\end{array}$ & $\begin{array}{l}\text { Continue timely } \\
\text { servicing of new } \\
\text { training and } \\
\text { development needs } \\
\text { (being responsive to } \\
\text { changing mission) }\end{array}$ & $\begin{array}{l}\text { Continue delivering } \\
\text { training onsite and } \\
\text { through distance and } \\
\text { multimedia methods }\end{array}$ & $\begin{array}{l}\text { Continue promoting } \\
\text { innovations in } \\
\text { training }\end{array}$ & $\begin{array}{l}\text { Continue assist visits } \\
\text { Support mobile } \\
\text { training teams }\end{array}$ \\
\hline
\end{tabular}




\section{Subtopic 3.6 How PBT and SAT Relate to Discussed Processes, Methods, and Models}

How do these guides, processes, and models relate to Performance-Based Training (PBT) and the Systematic Approach to Training (SAT)?

The media/method selection models are clearly part of PBT and SAT. Cost-effectiveness and cost-benefit analyses also fit under the PBT and SAT umbrellas, although they are considerably more demanding technically than most other steps in the model and are best performed by skilled analysts or staffers at headquarters organizations and for large, system-wide problems. Without cost-effectiveness or cost-benefit analysis, it is difficult to justify the initial costs for most ATT. With these analyses, the decisions sometimes appear to be almost common sense. The necessity in using these analyses is to continually gather data, evaluate, and assess effectiveness so that any new needs that surface can be considered without having to construct (and reconstruct) the analysis infrastructure each time.

The technology readiness and acceptance models are consistent with PBT and SAT but newer in origin than these models and therefore "ahead" in their thinking. These readiness models are very much "systems thinking" even though they may not be as engineering-related as they are social-science and human-centered. 


\section{TOPIC 4. CURRENT STATUS AND NEEDS OF DOE RELATTVE TO ATT}

This topic addresses exceptionally difficult questions, all but the first two of which are beyond the original scope of this study. Regardless of their difficulty, it is believed that these questions need to be raised and eventually answered if DOE is to utilize ATT effectively. Note that the question asked in Subtopic 4.3 (the needs and problems of DOE that can be resolved with ATT) is perhaps backwards. DOE, in applying the principles inherent in PBT and SAT, will use needs analysis initially to drive the entire education and training system. Then, with needs defined, the cost-benefit of ATT can be assessed in relation to individual needs or groups of needs. Because this report is specifically addressing the potential for ATT within DOE, the question in Subtopic 4.3 has been included as written. Finding the answer to this question should be top priority because without this information there is little point in even asking the questions in Subtopics 4.4 through 4.7, and it is almost impossible to recommend any other steps.

The information obtained from previous portions of the study have been analyzed and professional judgment used to estimate DOE's current status in relation to the GARTH Model and to identify what specific lessons DOE can learn from the other organizations surveyed. No efforts were made to answer the questions defined in Subtopic 4.3 through 4.7, since they are beyond the scope of this study.

\section{Subtopic 4.1 DOE's Current Level of Readiness to Use ATT}

\section{Where is DOE as a whole with regard to its readiness to adopt and effectively implement ATT?}

What is the current maturity level of the DOE's training system? Are all the components of the training system at the same level? If not, what impact should this have on immediate plans?

As noted with the software Capabilities Maturity Model, over $80 \%$ of all software organizations evaluated were at Level I initially. One could argue that the maturity models are "biased" to place most organizations at the bottom level. The crisis created by this disparity of where the organizations believed they were versus where the assessment told them they were is so great that they either go into a state of denial or accept the findings and start looking for help. An initial level of somewhere above a flat-out 1 and yet significantly below a 2 for the DOE would be consistent with the Defense Nuclear Facilities Safety Board (DNFSB) findings that prompted a major response starting with the 93-3 Implementation Plan. While this assessment would apply to 
the organization as a whole, outstanding components of the overall system are clearly at Level 2 or above. The Central Training Academy is an excellent example of a Level 3 enclave within the DOE organization. The contractor General Employee Training (GET) program and site-wide coordination efforts at Hanford and Savannah River (and probably others) are at Level 2 or higher.

\section{Implications for DOE's Training System}

Assuming that DOE's training system is at maturity Level $1+$, how does that knowledge help? What does it mean? For one thing, it means that first priority efforts should be devoted to bringing the whole system up to Level 2. It also means that the Department is still a few years away from wide-spread use of the advanced training technologies that were presented in Subtopic 1.2 of this report (wide-spread use requires a Level 3 organization). It also points out the enormous commitment required over a long period of time to achieve world-class status, if such a vision is desirable.

While immediate adoption of integrated data and video networking systems for multimedia and distance learning delivery is not supportable because of lack of other organizational infrastructure, now is the time to start strategic efforts to ensure that such networks are in place when the organization is ready for them. However, the expectation of solving all the Department's training problems overnight if such a system could be put into place is unrealistic and doomed to fail because the system is not ready to manage and effectively use such a system. Again, it is analogous to the Level 1 software engineering organization trying to jump over Level 2 in pursuit of adopting CASE tools.

\section{Possible Progression Scenarios for DOE's Training System}

There are at least three possible scenarios through which DOE could move over the next 10 years. The figure below illustrates these three scenarios shown as related curves. Two special, hypothesized lines are also plotted on the graph, denoted by repeated sets of three dots. The bottom line represents the minimum level required by a training organization to stay competitive in today's world, while the top line represents the minimum level at which world-class organizations are and will be operating. Note that only curve A moves into the area above this line. 
Curve $A$ is called "Put a man on the moon in ten years." It represents the response that is Incredibly American (see reference to book by this titie). Once a severe enough crisis occurs making denial no longer possible, Americans often do respond by adopting and realizing an "impossible dream." This dream becomes real in the shared imagination of those putting forth superhuman effort to bring it about. Such a dream was triggered by the crisis of Sputnik and President Kennedy's visionary response. The secret of this sequence is to use the present crisis (e.g., DNFSB findings, requirements by new leaders) to create a generally-accepted but lofty impossible dream, then systematically work toward it. Unless the crisis has been sufficiently appreciated and all believe that their survival depends on reaching the dream, the effort is doomed beyond the first few years. It has been said "Make no small plans, for they have no power to lift men's souls." Curve A requires soul-lifting to break through all kinds of cultural and organizational paradigm barriers. Because people also hate to be disappointed or manipulated, curve A requires an extra large dose of credibility which is at the core of leadership. This curve is remarkably steep. Note that even a successful moon shot effort has a tailing off as is depicted during FY 2002 and 2003. 
Curve $B$ is the "steady as she goes," or idealized project management curve (straight line). This represents what managers everywhere are taught is the best way to accomplish major projects. It is technically marvelous. In contrast to the impossible dream, however, it may not be able to pull down the needed resources or inspire the emotional commitment required. As illustrated in Figure 1, this sequence would not move the Department into the competitive zone until the year 2000 and by that time, the project is likely to be considered less important because of its relative success (see curve B2-"rest on laurels," which starts descending in 1999).

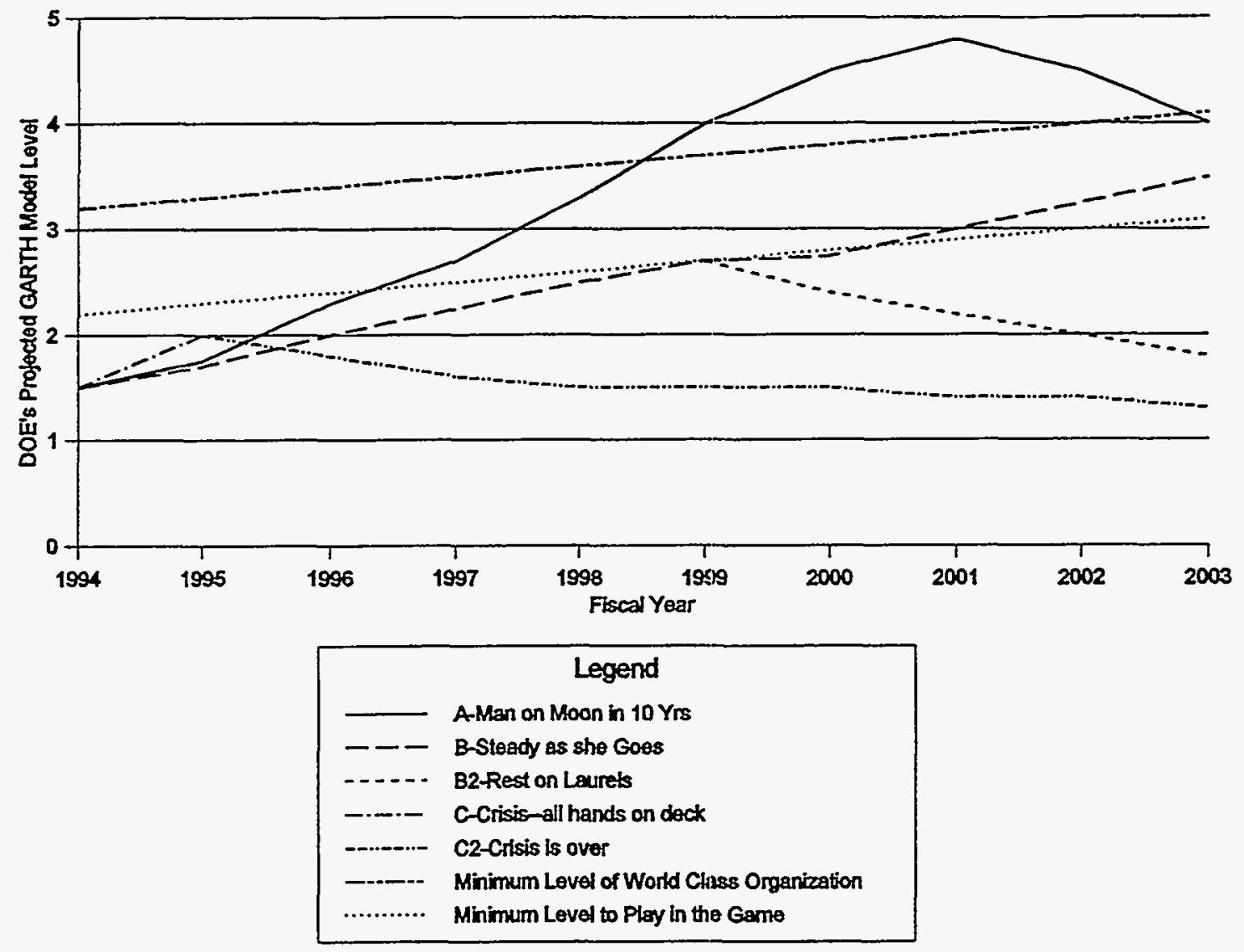

Figure 1. DOE progression scenarios: impossible dream, steady, or crisis.

Sustaining curve B may be psychologically next to impossible for American organizations. Curve $C$ is the crisis- "all hands on deck" fire-fighting curve where the faster and larger the response, the better. This curve rises more steeply than all the others but then subsides quickly (see curve C2-"crisis is over"). Just as Level 1 is the default level for most software engineering and training systems, Curve $C$ is the default path because it directly reflects the state of the 
organization. A Level 1 organization handles the bulk of its problems in fire-fighting fashion. Given the ever-changing priorities, it is most likely that present pressures for a greatly upgraded DOE work force will be replaced by some other real or perceived near-disaster, leaving the ship of training improvement without wind in its sails.

\section{Subtopic 4.2 DOE's Estimated Current and Comparative GARTH Level}

How does DOE compare to similar organizations in its ability to use ATT appropriately and what specific lesson(s) can be learned from each organization studied?

This subtopic looks at who DOE should seek to learn from and emulate. It also addresses how looking at the GARTH levels of the organizations visited can help DOE plan for the future.

\section{Comparision of DOE With Other Organizations}

Figure 2 summarizes the best guess of where, minimally, the types of organizations visited or otherwise researched fall along the maturity continuum. The word minimally is used because it is likely that many of the organizations are actually at a higher level than the limited data gathered during this study may have indicated. The purpose of attempting to place the organizations along the scale is to aid DOE in selecting cases to study further and benchmark. Every organization researched had at least one positive feature that would benefit DOE. Many organizations had several outstanding features. For each organization, one or more key features for DOE to note or emulate is included in the far right column of Table 32 below. Note that the organizations are ordered in this table based on the best estimate of their relative position to each other along the maturity continuum. Note also that the research organizations are listed but the type of organization box is shaded. In their case, the rating refers to the content of the work they are exploring and where it falls on the continuum, rather than the organization's maturity. 


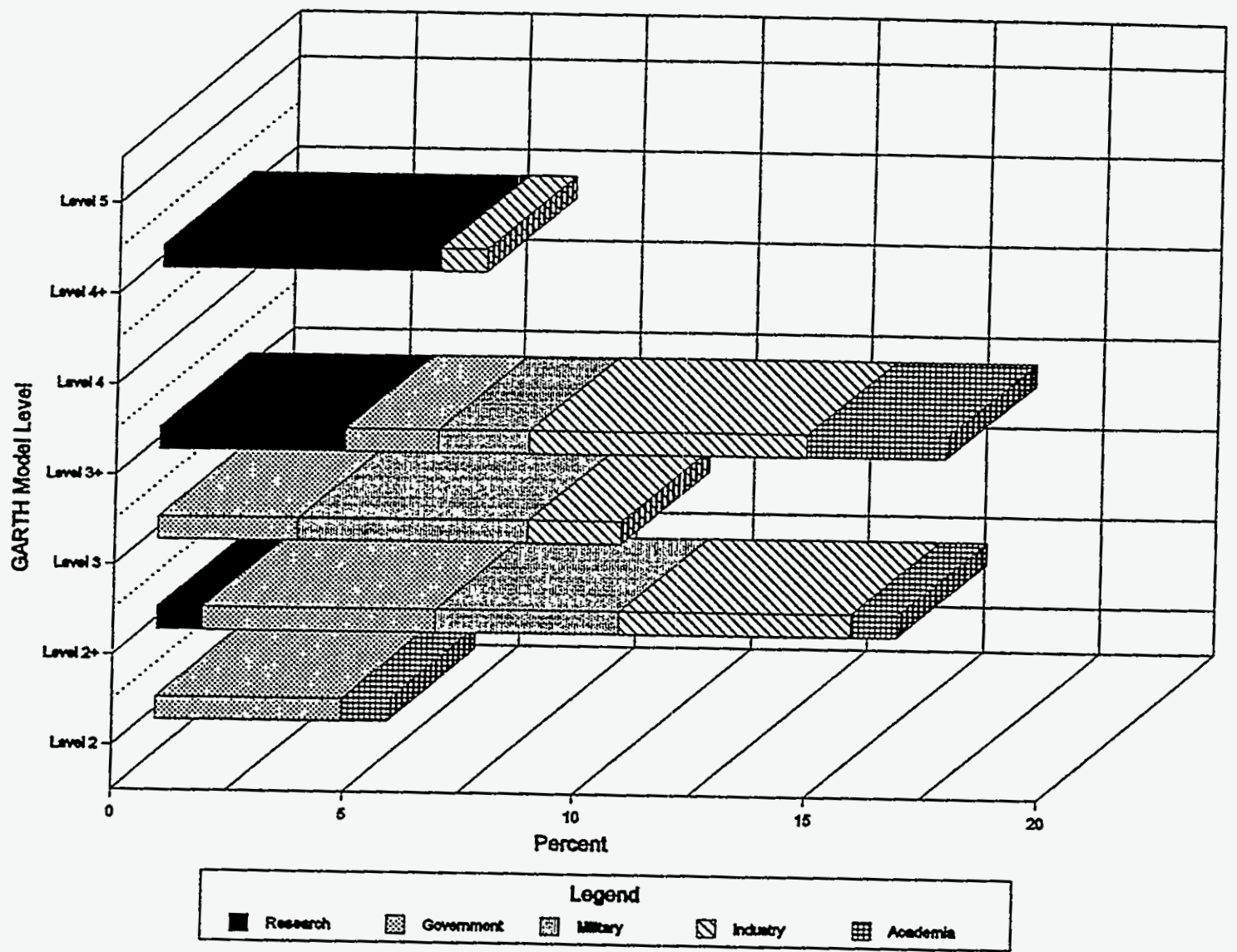

Figure 2. Summary of levels found.

Applying the principle discussed earlier of focusing developmental activities on the next step, it should be most helpful for DOE to find current lessons learned from those organizations at Levels 2 and $2+$. From those at Level 3 and above can be gained more long-term, strategic knowledge for creating infrastructure that takes many years to establish. If creating the infrastructure is not started now, it can at least be thought about.

Figure 3 shows the estimated present (1994) and future (1998 and 2002) cumulative status of training organizations around the country. This forecast may be overly optimistic in that major shifts this dramatic did not occur during the last eight years in terms of training systems maturity, so why should they be expected to occur over the next eight years? 


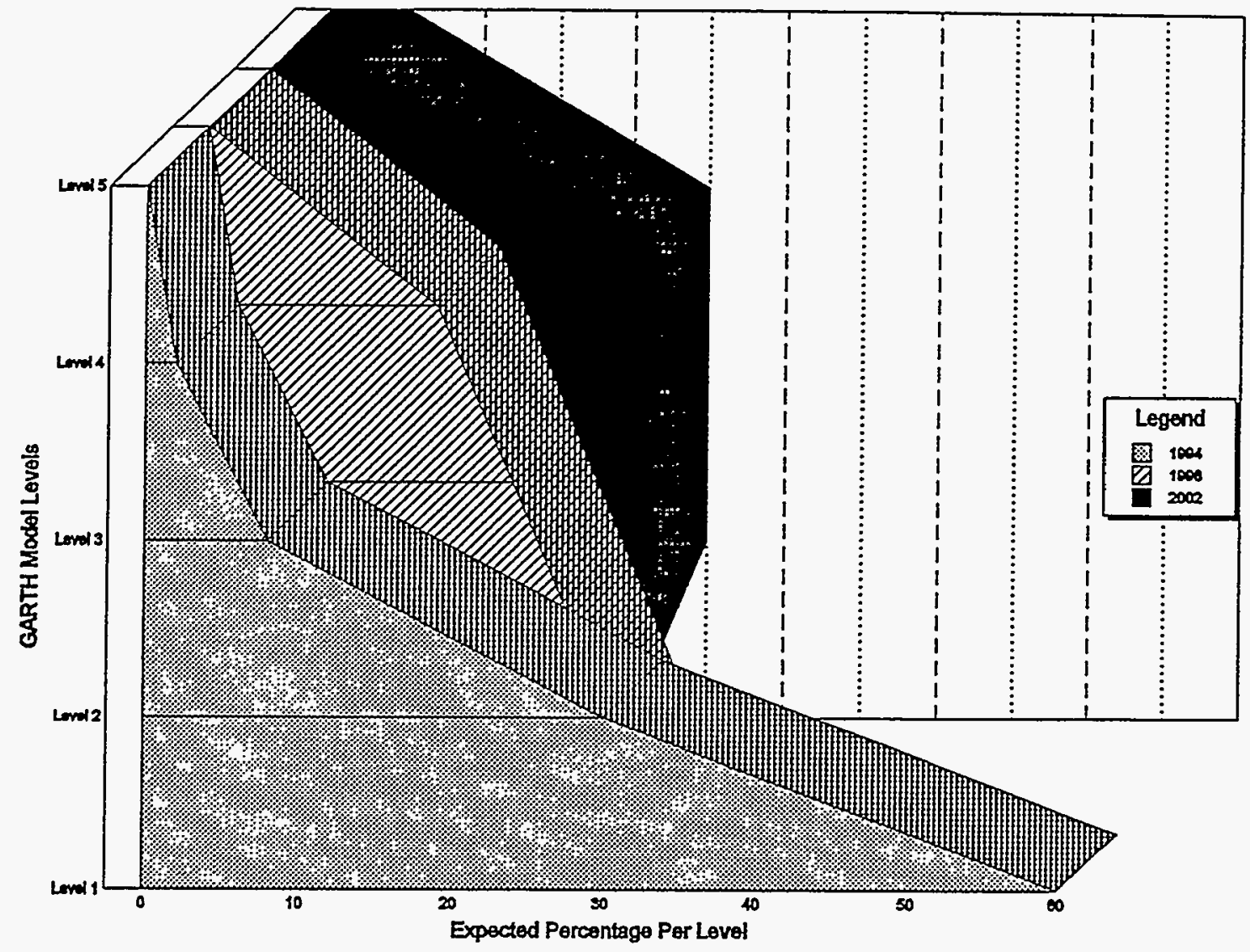

Figure 3. Eight year forecast.

One reason is the realization that training technology, if used properly, can greatly reduce costs and increase effectiveness. This improved cost-benefit will serve as a major driver to help Level 1 organizations move to Levels 2 and then Level 3, enabling them to take advantage of these benefits. With more organizations also starting to reach Level 4 , the disparity between the world-class and the non-competitive organizations will become so great that the Level 1 organizations will have to begin changing or die. 
Table 32. Estimated levels and important features to note from surveyed organizations.

\begin{tabular}{|c|c|c|c|}
\hline $\begin{array}{c}\text { Estlmated } \\
\text { Level' }^{1}\end{array}$ & $\begin{array}{c}\text { Type of } \\
\text { Institution }\end{array}$ & $\begin{array}{l}\text { Institution/ } \\
\text { Facility }\end{array}$ & Important Features for DOE HQ to Note/Emulate \\
\hline $4+$ & 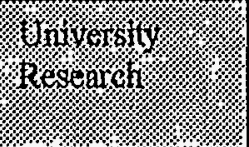 & $\begin{array}{l}\text { Northwestern } \\
\text { University }\end{array}$ & $\begin{array}{l}\text { While much of the work being done is perhaps too advanced for DOE currently DOE should continue } \\
\text { to monitor Northwestern's progress in involving students in learning. The case-based materials being } \\
\text { developed for Arthur Andersen \& Co. probably epitomize this type of professional training. }\end{array}$ \\
\hline $4+$ & 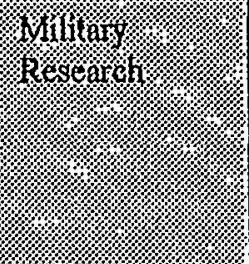 & $\begin{array}{l}\text { Naval Training } \\
\text { Systems Center }\end{array}$ & $\begin{array}{l}\text { Two important areas should be watched. First, the research of the relative importance of functional } \\
\text { versus physical fidelity in simulations and second, the extensive, on-going work on team training. } \\
\text { Simulation has great potential for DOE in nuclear, environmental, and other areas so that balancing the } \\
\text { physical fidelity with the functional fidelity is important. Likewise, many DOE jobs require extensive } \\
\text { communications and team interactions for which it can be difficult to train. NTSC is a good source for } \\
\text { learning how best to do this. }\end{array}$ \\
\hline $4+$ & 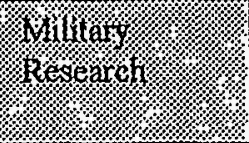 & $\begin{array}{l}\text { Brooks, Randolph Air } \\
\text { Force Bases }\end{array}$ & $\begin{array}{l}\text { Among other advanced projects going on here are intelligent tutoring systems and the creation of semi- } \\
\text { automated courseware development tools (AIDA). Also produced and updated here are manuals and } \\
\text { guides for managers of training such as the ones abstracted for this report. }\end{array}$ \\
\hline $4+$ & Industry & Hewlett-Packard-HQ & $\begin{array}{l}\text { One of the world leaders, } \mathrm{HP} \text { would be an excellent company to watch closely. If any kind of } \\
\text { professional advisory board is ever put together to assist DOE, the corporate VP for Performance } \\
\text { Improvement should be considered. } M P \text { is a leader in using technology appropriately to meet their } \\
\text { worldwideneeds. }\end{array}$ \\
\hline $4+$ & & $\begin{array}{l}\text { Florida State } \\
\text { University, Center for } \\
\text { Educational } \\
\text { Technology }\end{array}$ & $\begin{array}{l}\text { While this center has focused its work on meeting the needs of the public school, the concept of putting } \\
\text { tools in the hands of the learners and teachers is eminently reasonable. The tools they are currently } \\
\text { building for K-12 students should be watched and eventually adapted for the DOE work force. }\end{array}$ \\
\hline $4+$ & 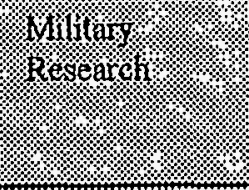 & $\begin{array}{l}\text { Army Research } \\
\text { Institute (Orlando, } \\
\text { Florida) }\end{array}$ & $\begin{array}{l}\text { This research office is focusing much of its effort on studying the pre-conditions and effectiveness of } \\
\text { using virtual environments for training. Their approach is systematic and should provide the } \\
\text { government and training world with important baseline information about what can effectively be } \\
\text { taught with VR and which students can and cannot benefit. }\end{array}$ \\
\hline $4+$ & 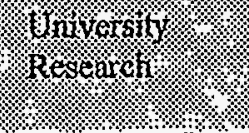 & $\begin{array}{l}\text { University of } \\
\text { Pittsburgh, LRDC }\end{array}$ & $\begin{array}{l}\text { Their work for the Air Force in developing troubleshooting intelligent tutors has been of breakthrough } \\
\text { proportions. If DOE is faced with any similar problems (e.g., incorrect diagnoses and extended } \\
\text { training requirements to teach troubleshooting), the work of this lab should be carefully reviewed. }\end{array}$ \\
\hline
\end{tabular}


Table 32. Estimated levels and important features to note from surveyed organizations.

\begin{tabular}{|c|c|c|c|}
\hline $\begin{array}{c}\text { Estimated } \\
\text { Level }^{\prime}\end{array}$ & $\begin{array}{c}\text { Type of } \\
\text { Institution }\end{array}$ & $\begin{array}{l}\text { Institution/ } \\
\text { Facility }\end{array}$ & Important Features for DOE HQ to Note/Emulate \\
\hline $4+$ & 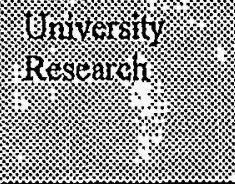 & $\begin{array}{l}\text { University of Central } \\
\text { Florida, Institute for } \\
\text { Simulation and } \\
\text { Training }\end{array}$ & $\begin{array}{l}\text { This group does very diverse work, almost all in support of military technical training. They have } \\
\text { assisted with numerous distance learning and remote simulation-based training projects, courseware } \\
\text { development, and advanced classroom developments. They have a very broad base of expertise. }\end{array}$ \\
\hline $3+$ & 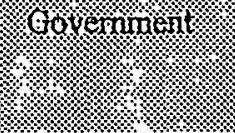 & NASA & $\begin{array}{l}\text { There are undoubtedly many things that could be learned from NASA. The Intelligent Tutoring } \\
\text { Systems (ITS) produced by experts at the Johnson Space Center are excellent examples of qualified } \\
\text { tutors. }\end{array}$ \\
\hline $3+$ & Industry & $\begin{array}{l}\text { IBM Skill Dynamics } \\
\text { Performance Support } \\
\text { Systems }\end{array}$ & $\begin{array}{l}\text { Recently, the director of this function indicated that IBM has required the consideration of constructing } \\
\text { and using a performance support system before any internal training can be developed. In essence, } \\
\text { IBM is committing to a Level } 4 \text { technology approach as their default. }\end{array}$ \\
\hline $3+$ & Industry & $\begin{array}{l}\text { Hewlett-Packard, } \\
\text { Printer division }\end{array}$ & $\begin{array}{l}\text { The usage rate of the learning center has been extremely high across all the shifts. HP has also found } \\
\text { ways to cut the development costs of the multimedia instruction and of the video that they deliver } \\
\text { remotely. }\end{array}$ \\
\hline $3+$ & $\begin{array}{l}\text { Academial } \\
\text { Industry }\end{array}$ & $\begin{array}{l}\text { National } \\
\text { Technological } \\
\text { University }\end{array}$ & $\begin{array}{l}\text { This institution knows how to create and deliver satellite courses all around the country and how to } \\
\text { manage student enrollments, etc. }\end{array}$ \\
\hline $3+$ & 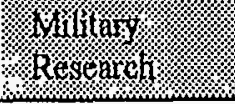 & $\begin{array}{l}\text { Army Research } \\
\text { Institute (Boise, Idaho) }\end{array}$ & Reserve component-wide range of skills and knowledge, from BNCOC to advanced training. \\
\hline $3+$ & Military & Air Force Academy & $\begin{array}{l}\text { Computers are everywhere including in each of the airman's rooms. The Academy has an exciting } \\
\text { multimedia development project that may be a model for a broad based hypermedia retrieval system. } \\
\text { They have a strong emphasis on evaluation so they can know what the true costs are as well as the } \\
\text { benefits. }\end{array}$ \\
\hline $3+$ & Industry & Dow Chemical & $\begin{array}{l}\text { Dow has been an early adopter of electronic performance support systems for team problem-solving } \\
\text { and decisionmaking, especially in solving quality problems. }\end{array}$ \\
\hline
\end{tabular}


Table 32. Estimated levels and important features to note from surveyed organizations.

\begin{tabular}{|c|c|c|c|}
\hline $\begin{array}{l}\text { Estimated } \\
\text { Level }^{\prime}\end{array}$ & $\begin{array}{c}\text { Type of } \\
\text { Institution }\end{array}$ & $\begin{array}{c}\text { Institution/ } \\
\text { Facility } \\
\end{array}$ & Important Features for DOE HQ to Note/Emulate \\
\hline $3+$ & I. & Utah State University & $\begin{array}{l}\text { One of the main thrusts at Utah State has been to find ways to automate instructional design and } \\
\text { development. The conference they host annually is well-attended and perhaps the best in the world on } \\
\text { this subject. }\end{array}$ \\
\hline $3+$ & $\begin{array}{l}\text { Academia/ } \\
\text { Industry }\end{array}$ & $\begin{array}{l}\text { Mind Expanding } \\
\text { University }\end{array}$ & $\begin{array}{l}\text { Provides credit courses to students all over the country. Provides the signal through local cable } \\
\text { companies or students can purchase their own dish. Most students record the classes for later } \\
\text { watching. Getting the information right into the home of the learner has been a major accomplishment, } \\
\text { as well as working out the payment and course credit arrangements. }\end{array}$ \\
\hline $3+$ & (3) & $\begin{array}{l}\text { Vanderbilt, Cognition } \\
\text { and Technology Group }\end{array}$ & $\begin{array}{l}\text { While much of their work is for } \mathrm{K}-12 \text {, this innovative center has created some outstanding examples of } \\
\text { case-oriented learning that keep the learners involved and help them apply what they learn to practical } \\
\text { situations. DOE training could benefit greatly by adopting some of the techniques used by these } \\
\text { professionals in their curriculum development and instructor training and inservice efforts. }\end{array}$ \\
\hline $3+$ & Academia & University of Maryland & $\begin{array}{l}\text { These learning theaters are marvelous, if used appropriately. A wide range of subjects have been very } \\
\text { successfully taught; some are technical, but many are humanities. Such a room in a training center } \\
\text { could be a real asset to DOE if it were reserved for the right courses and if the instructors had time to } \\
\text { prepare the media and the computer interactions that can be supporied. Eveniually, much of the same } \\
\text { experiences students have in these theaters can take place right at a worker's desktop. }\end{array}$ \\
\hline $3+$ & $\begin{array}{l}\text { Industry/ } \\
\text { Education }\end{array}$ & $\begin{array}{l}\text { Whittle } \\
\text { Communications }\end{array}$ & $\begin{array}{l}\text { Though financially strapped of late, Whittle Communications has been pushing the cutting edge of the } \\
\text { commercially viable. While the negotiations between the cable, phone, entertainment, and computer } \\
\text { companies have been proceeding, Whittle was out there actually doing it. The retrenchment they are } \\
\text { experiencing at the present may be proof in a way that a Level } 3 \text { or even a Level } 2 \text { approach needs to } \\
\text { be supported by enough maturity in the marketplace. As early leaders, they blazed the trail but are too } \\
\text { far ahead of the pack for the time being. }\end{array}$ \\
\hline $3+$ & Government & $\begin{array}{l}\text { DOE Central Training } \\
\text { Academy }\end{array}$ & $\begin{array}{l}\text { The work of this group is well known to many at DOE Headquarters. By all indications, this resource } \\
\text { should be utilized to the fullest. The manner in which the Academy has shifted from classroom-based } \\
\text { instruction to multimedia and distance learning should provide many important lessons learned and a } \\
\text { good working example for the rest of DOE. }\end{array}$ \\
\hline
\end{tabular}


Table 32. Estimated levels and important features to note from surveyed organizations.

\begin{tabular}{|c|c|c|c|}
\hline $\begin{array}{l}\text { Estimated } \\
\text { Level' }^{\prime}\end{array}$ & $\begin{array}{c}\text { Type of } \\
\text { Institution } \\
\end{array}$ & $\begin{array}{l}\text { Institution/ } \\
\text { Facility }\end{array}$ & Important Features for DOE HQ to Note/Emulate \\
\hline $3+$ & Industry & $\begin{array}{l}\text { Caterpillar } \\
\text { Incorporated }\end{array}$ & $\begin{array}{l}\text { Interestingly enough, the internal training at Caterpillar has been anything but innovative while their } \\
\text { external training and support has been world class. This undoubtedly reflects the reality of where } \\
\text { distance learning and multimedia are cost-effective and where they may not be. }\end{array}$ \\
\hline $3+$ & Industry & $3 \mathrm{M}$ & $\begin{array}{l}\text { According to the person responsible for utilizing distance education resources at } 3 \mathrm{M} \text { to foster } \\
\text { professional development, } 3 \mathrm{M} \text { has been very successful in supporting the continuing education of their } \\
\text { engineers and scientists, through pulling down programs and hosting their internal broadcasts. }\end{array}$ \\
\hline $3+$ & Industry & $\begin{array}{l}\text { IBM Skill Dynamics } \\
\text { Regional Centers }\end{array}$ & $\begin{array}{l}\text { Evidently IBM has been able to keep the personnel requirements for running these centers to a } \\
\text { minimum. }\end{array}$ \\
\hline $3+$ & $\begin{array}{l}\text { Government } \\
\text { (GOCO) }\end{array}$ & Hanford Site & $\begin{array}{l}\text { WHC was one of the first DOE contractors to get serious about using computer-based instruction to } \\
\text { reduce training time and improve learning effectiveness. They have gone through several revisions of } \\
\text { the GET courses to ensure that they are requirement driven. Their centers are kept busy by centralized } \\
\text { scheduling. Another excellent resource for DOE. }\end{array}$ \\
\hline 3 & Government & $\begin{array}{l}\text { State Department } \\
\text { Foreign Affairs } \\
\text { Institute }\end{array}$ & $\begin{array}{l}\text { Their recently constructed center was well designed and supports a wide variety of learning and } \\
\text { teaching methods including several language labs, small group teaching rooms, as well as simulation } \\
\text { and gaming rooms. They are now experts in learning to work with an architect to get what they want. }\end{array}$ \\
\hline 3 & Government & Postal Service & $\begin{array}{l}\text { They have primarily audio conferenced in the past. They also have had a good response with technical } \\
\text { hands-on training using the actual field equipment. Their downtime record, due to improperly } \\
\text { returning such equipment to proper operational status, has been far less than expected. The benefits to } \\
\text { the learners have been noticeable-they are learning to maintain their own machines, not some generic } \\
\text { piece of hardware in a laboratory somewhere. }\end{array}$ \\
\hline 3 & Government & FBI Training Center & $\begin{array}{l}\text { These people know how to bring people in, take care of them (house, feed, teach) and send them on } \\
\text { their way. The center is well-supported with a dedicated staff of media experts who have recently } \\
\text { helped refurbish the small, theater-style classrooms. }\end{array}$ \\
\hline 3 & Military & $\begin{array}{l}\text { Navy Medical } \\
\text { Training }\end{array}$ & $\begin{array}{l}\text { They have recently changed their standards from IVD to CD-ROM. When it comes to creating a huge } \\
\text { library of multimedia and distributing it all around the world, these people are experts. }\end{array}$ \\
\hline
\end{tabular}


Table 32. Estimated levels and important features to note from surveyed organizations.

\begin{tabular}{|c|c|c|c|}
\hline $\begin{array}{l}\text { Estimated } \\
\text { Level }^{\prime}\end{array}$ & $\begin{array}{c}\text { Type of } \\
\text { Institution }\end{array}$ & $\begin{array}{l}\text { Institution/ } \\
\text { Facility }\end{array}$ & Important Features for DOE HQ to Note/Emulate \\
\hline 3 & Military & $\begin{array}{l}\text { Army Professional } \\
\text { Training (Fort Eustis, } \\
\text { VA.) }\end{array}$ & $\begin{array}{l}\text { This is a Cadillac system that is working because the resources were bought and paid for without } \\
\text { primary consideration for short-term cost effectiveness. That being the case, they are under the gun to } \\
\text { keep the airwaves busy and thereby get the greatest benefit for the money already spent. The model } \\
\text { they are using supports the student so well that if the transmission is broken, the local facilitator can } \\
\text { actually continue. For most purposes this may be far too expensive, but for a pioneering effort where } \\
\text { students' reactions can make or break the system, it has proven successful. }\end{array}$ \\
\hline 3 & Military & $\begin{array}{l}\text { Army Logistics } \\
\text { Management College } \\
\text { (Fort Lee, VA.) }\end{array}$ & $\begin{array}{l}\text { This is a heavily-used system and apparently very cost-effective. One-way video and 2-way audio is } \\
\text { considered adequate. An efficient and effective instructor training program supports the course } \\
\text { delivery efforts and improves the quality of the courses. }\end{array}$ \\
\hline 3 & Military & $\begin{array}{l}\text { Army Artillery School } \\
\text { (Fort Sill) }\end{array}$ & $\begin{array}{l}\text { This training group has a well-balanced approach to media. The center includes multimedia and a } \\
\text { satellite classroom. }\end{array}$ \\
\hline 3 & Military & $\begin{array}{l}\text { Air Force Institute of } \\
\text { Technology }\end{array}$ & This is a serious player in the distance learning game. \\
\hline 3 & Industry & Union Pacific Railroad & $\begin{array}{l}\text { Union Pacific has successful upgraded the skills of their conductors to include data entry into their } \\
\text { national railcar tracking system. The training was done using IVD courseware that simulated the actual } \\
\text { devices. }\end{array}$ \\
\hline 3 & Industry & Shell Oil & Article noted cost effectiveness as a key benefit to this approach. \\
\hline $2+$ & Government & $\begin{array}{l}\text { FAA-distance } \\
\text { learning }\end{array}$ & $\begin{array}{l}\text { The FAA's work in looking at their requirements and doing a careful cost-benefit analysis of the } \\
\text { various distance learning options is a model that DOE could use and should consider for their own } \\
\text { needs. }\end{array}$ \\
\hline $2+$ & Industry & $\begin{array}{l}\text { Arthur Andersen \& } \\
\text { Company }\end{array}$ & $\begin{array}{l}\text { Arthur Andersen has used its training center in St. Charles, Illinois, as a kind of professional boot } \\
\text { camp. It allows their newly recruited professionals a chance to become acculturated. The center can } \\
\text { handle around } 1500 \text { and functions somewhat like a small college with dorms, cafeterias, etc. The } \\
\text { company is also exploring multimedia case-based capstone exercises (see Northwestern University). }\end{array}$ \\
\hline
\end{tabular}


Table 32. Estimated levels and important features to note from surveyed organizations.

\begin{tabular}{|c|c|c|c|}
\hline $\begin{array}{c}\text { Estimated } \\
\text { Level' }^{\prime}\end{array}$ & $\begin{array}{l}\text { Type of } \\
\text { Institution }\end{array}$ & $\begin{array}{l}\text { Institution/ } \\
\text { Facility }\end{array}$ & Important Features for DOE HQ to Note/Emulate \\
\hline $2+$ & Industry & $\begin{array}{l}\text { IBM Skill Dynamics } \\
\text { Technical Training } \\
\text { Center }\end{array}$ & $\begin{array}{l}\text { IBM has learned many lessons over the years about course registration and scheduling, instructor and } \\
\text { developer certification, as well as effective use of laboratory space. Skill Dynamics, as a whole, has } \\
\text { capitalized on their course catalog which is a prime asset. }\end{array}$ \\
\hline $2+$ & Industry & Dow Chemical & $\begin{array}{l}\text { This top of the line training center allows for powerful group instruction supported by every } \\
\text { conceivable kind of medium, all controlled by the instructor with the help of some easy-to-use software } \\
\text { which can be preprogrammed. }\end{array}$ \\
\hline $2+$ & Academic & $\begin{array}{l}\text { Brigham Young } \\
\text { University }\end{array}$ & $\begin{array}{l}\text { The placement of the equipment in the advanced classroom is instructive including cameras facing } \\
\text { forward allowing for students to film their presentations and for connecting with other classrooms on } \\
\text { campus or at a distance. }\end{array}$ \\
\hline $2+$ & Government & $\begin{array}{l}\text { NRC Technical } \\
\text { Training Center }\end{array}$ & $\begin{array}{l}\text { There are numerous features at the technical center that should be watched and emulated including the } \\
\text { use of their network for instruction-linking into their simulators, use of IVD for virtual plant } \\
\text { walkthroughs, instructor training and certification, efficiency in staffing and running the center, etc. }\end{array}$ \\
\hline $2+$ & Military & $\begin{array}{l}\text { Air Force Air Combat } \\
\text { Command }\end{array}$ & $\begin{array}{l}\text { The PERI technique is being used extensively to develop training to help teach troubleshooting to } \\
\text { aircraft mechanics. Nice way to reduce time to build expertise. }\end{array}$ \\
\hline $2+$ & Industry & Motorola University & $\begin{array}{l}\text { Of all the training organizations investigated, this one seems to have the broadest mission and most } \\
\text { diverse staff. Motorola is very concerned with fostering quality and other top-down initiatives through } \\
\text { the effective use of its training resources. All company-wide training is provided by the central training } \\
\text { function. Also, as Motorola goes into new markets, representatives from Motorola U go with the } \\
\text { advance party to learn about the culture and business environment. This has proven very successful. }\end{array}$ \\
\hline $2+$ & Military & $\begin{array}{l}\text { Defense Acquisition } \\
\text { University (DAU) }\end{array}$ & $\begin{array}{l}\text { This approach has worked remarkably well for a number of reasons. The money trail is always very } \\
\text { clear. The University also has a tightly framed mission, the resources to accomplish that mission, and } \\
\text { some ambitious, but feasible, goals in terms of graduates within specific career areas. Their approach } \\
\text { for establishing qualifications in each of the acquisition areas is also something to examine seriously } \\
\text { and perhaps learn from. }\end{array}$ \\
\hline
\end{tabular}


Table 32. Estimated levels and important features to note from surveyed organizations.

\begin{tabular}{|c|c|c|c|}
\hline $\begin{array}{l}\text { Estimated } \\
\text { Level }^{1}\end{array}$ & $\begin{array}{c}\text { Type of } \\
\text { Institution }\end{array}$ & $\begin{array}{l}\text { Institution/ } \\
\text { Facility } \\
\end{array}$ & Important Features for DOE HQ to Note/Emulate \\
\hline $2+$ & mesearch & $\begin{array}{l}\text { University of Illinois, } \\
\text { Urbana Champaign }\end{array}$ & $\begin{array}{l}\text { This research and development group has made some astonishing progress in discovering how to teach } \\
\text { complex, poorly structured knowledge. Because the oversight role that many DOE workers perform is } \\
\text { both complex and ill-structured, it is likely that these theories and methods would be of great value to } \\
\text { DOE. }\end{array}$ \\
\hline $2+$ & $\begin{array}{l}\text { Government } \\
\text { (GOCO) }\end{array}$ & Savannah River Site & $\begin{array}{l}\text { Current efforts by Westinghouse to collaborate with a commercial instructional development firm is a } \\
\text { practice worth noting. In the past, many of the learning centers have been under-utilized because } \\
\text { alternative lecture courses were offered. }\end{array}$ \\
\hline $2+$ & Government & GAO & $\begin{array}{l}\text { As with many other organizations, GAO is looking into distance learning applications. Their learning } \\
\text { center and classrooms are well-managed. }\end{array}$ \\
\hline $2+$ & Military & $\begin{array}{l}\text { National Defense } \\
\text { University-Information } \\
\text { Resources } \\
\text { Management College } \\
\text { (NDU-IRM) }\end{array}$ & $\begin{array}{l}\text { This college is essentially a graduate program but the curriculum is carefully thought through. The } \\
\text { instructors have special podiums for controlling all the media. }\end{array}$ \\
\hline $2+$ & Military & Air Force University & $\begin{array}{l}\text { Moving away from strictly classroom instruction to other forms. Developed the media selection } \\
\text { worksheet included in Appendix B. }\end{array}$ \\
\hline $2+$ & Industry & $\begin{array}{l}\text { Tennessee Valley } \\
\text { Authority }\end{array}$ & $\begin{array}{l}\text { Moving more and more to computer-based instruction and multimedia. Leader in thinking through the } \\
\text { need to collaborate in the development of the instructional packages to reduce costs and improve } \\
\text { quality. TVA is interested in effectiveness issues surrounding the use of advanced training } \\
\text { technologies. }\end{array}$ \\
\hline $2+$ & Government & $\begin{array}{l}\text { NRC White Flint II } \\
\text { Training Center }\end{array}$ & $\begin{array}{l}\text { Currently checks out videos and CBT materials to staff for use at home. Exploring delivery of } \\
\text { multimedia via the LAN. Studying feasibility of downloading files then deleting from local machines } \\
\text { when finished. }\end{array}$ \\
\hline $2+$ & Government & $\begin{array}{l}\text { IRS-Professional } \\
\text { Development Center }\end{array}$ & $\begin{array}{l}\text { Taking a performance-based approach in examining at required capabilities of workers who will be } \\
\text { performing multiple tasks in a cross-functional approach to servicing tax needs-taking experts in a } \\
\text { given business area and familiarizing and cross training them on many possible functions rather than } \\
\text { having them specialize in one part of tax collecting, auditing, etc. }\end{array}$ \\
\hline
\end{tabular}


Table 32. Estimated levels and important features to note from surveyed organizations.

\begin{tabular}{|c|l|l|l|}
\hline \hline $\begin{array}{c}\text { Estlmated } \\
\text { Level' }\end{array}$ & $\begin{array}{c}\text { Type of } \\
\text { Institution }\end{array}$ & \multicolumn{1}{|c|}{$\begin{array}{c}\text { Institution/ } \\
\text { Facility }\end{array}$} & Important Features for DOE HQ to Note/Emulate \\
\hline \hline 2 & Government & $\begin{array}{l}\text { USDA Graduate } \\
\text { School }\end{array}$ & $\begin{array}{l}\text { Very efficient operation. Contracts all the courses out to instructors and to facilities. Main product is } \\
\text { catalog and credit which is recognized by ACE. }\end{array}$ \\
\hline 2 & Government & $\begin{array}{l}\text { OPM Washington, DC } \\
\text { Regional Training } \\
\text { Center }\end{array}$ & $\begin{array}{l}\text { Has refurbished a Virginia office building into a very nice classroom building. Careful attention paid to } \\
\text { security, colors, lighting, etc. OPM is a possible model for DOE in the area of course development and } \\
\text { customization. Courses are managed by the central HR office but actually assigned out to the field } \\
\text { offices for development (or contractor oversight). Then, completed courses are distributed around the } \\
\text { country. The catalog is national in scope which can cause a problem when demand may not meet } \\
\text { expectations in a given region. }\end{array}$ \\
\hline 2 & Government & $\begin{array}{l}\text { IRS-Washington } \\
\text { Office Training Center } \\
\text { Professional } \\
\text { development center) }\end{array}$ & $\begin{array}{l}\text { The Professional Development Center is contracted out and appears to be well managed and utilized. } \\
\text { The center has full time counselors to help employees perform needs analyses and planning for their } \\
\text { careers and retraining. This is especially relevant given the downsizing that the IRS is currently } \\
\text { experiencing. Their center has extensive off-the-shelf multimedia (IVD) packages to support a wide } \\
\text { range of skills in office management, communications, software, etc. }\end{array}$ \\
\hline 2 & Academic & $\begin{array}{l}\text { University of Florida, } \\
\text { Medical School }\end{array}$ & $\begin{array}{l}\text { Excellent example of using the subject matter expert to develop multimedia training packages at a low } \\
\text { cost. The instructional designer creates the templates for the expert to complete and then helps the } \\
\text { expert tie video segments to the script to make a high quality product. }\end{array}$ \\
\hline
\end{tabular}

${ }^{1}$ The level assigned is an estimate based on the limited data gathered. The number represents a low estimate in that we would be astonished if the organizalions (or part that we vislted/researched) were aclually at a lower level. Conversely, it is very likely that some or all of these organlzatlons are aclually at an even higher level than estimated in 1994 . 2 Shaded areas are research, non-shaded are operallonal 


\section{Implications of the GARTH Model for DOE}

GARTH, as a maturity model, provides a helpful set of top-down organizing principles to reinterpret the data obtained from the bottom-up survey. From this viewpoint, the following points become clear:

The GARTH Model emphasizes the importance of DOE's centralizing of its information sharing function and the dissemination of DOE-wide policies, procedures, and standards for training and professional qualification. These key activities are essential for moving to Level 2. One unglamourous but vital (potential) role of a training center, whether an actual facility or a virtual facility, might be to perform many of these integration and coordination functions that have hitherto been neglected. If a center is never realized, then the function must be picked up and performed elsewhere. Without catalogs and resource sharing among the field offices and headquarters, redundancy will continue and millions of dollars will be wasted. To be of value, any cataloging and/or sharing must be maintained and measure up to acceptable quality standards.

Organizations that are currently at Levels 2-3, and have recently upgraded their processes are prime candidates for study of lessons learned. This survey has identified many good examples of organizations that have brought their course catalogs, scheduling, administration, and registration processes under control (though not always addressing real requirements or users' needs). Other organizations have been remarkably successful in streamlining their course development and delivery to dramatically reduce costs while maintaining previously set levels of service.

The immediate flooding of technology into training will not turn the current semi-chaotic system into order. In fact, such a move would create additional chaos. However, once the needed processes, standards, and plans are in place and the culture has started to change, widespread use of technology will not only be possible but should greatly enhance the individual worker's ability to learn and grow, while reducing costs. Without the infrastructure and wellthought-out plans for co-developing and sharing instructional packages, multimedia and distance learning become expensive toys or worthless dust gatherers.

A long-term strategic plan is needed that goes beyond careerism and self-centered development to organizational effectiveness and system/need-driven performance enhancement. Such a plan needs to look at the reality of what it takes to change a huge, dispersed, unruly, and multifaceted training system as DOE has at present. The changes are possible in the long term but the system will strongly resist quick fixes or panaceas. Ideally, the current high priority of training will remain for a number of years and the energy generated by recent crises will enable a "man of the moon in ten years" response rather than a fire-fighting, then neglectful, reaction.

Eventually, training as a separate concept may need to disappear and organizational, team, and personal learning concepts take its place as work becomes more and more complex and teams become more self-directive and responsible for organizational learning. 
While short-term goals are being set and actions taken to move to Level 2, it is VERY IMPORTANT TO LEARN from the Level 3 and 4 organizations NOW for clues as to what additional infrastructure changes should be STARTED NOW and to help prepare leaders psychologically for the changes that are coming.

While the model has definite limitations, it is hoped that the leaders of DOE training systems can use its simple power to prioritize and clarify many of the issues surrounding technology. It is also hoped that the GARTH model coupled with the data obtained by this survey, will help the Department to move forward as quickly and steadily as possible to build a strong and mature training system.

\section{Subtopic 4.3 Diagnosis First then Find ATT Solutions}

What needs and problems does DOE have that ATT can help meet and resolve, thus creating significant improvements in competence and effectiveness while reducing costs?

This is the most important question for DOE to ask and attempt to answer immediately. Just as there are table-top methods to expedite various kinds of job and task analyses, it is likely that expert estimation methods can be developed for a comprehensive needs analysis that would be $80 \%$ or more accurate and allow the Department to move ahead. Part of the data to be gathered must come from applying the new missions and directions of the Department. Open Search Conferences have become a powerful means of shortcutting many of the delays inherent in creating consensus in large, diffuse organizations. Given high enough priority and visibility, with sufficient background work done, it is possible that such a stakeholder conference could be held and a draft needs analysis and training mission/function future selection activity completed within a few months time.

\section{Subtopic 4.4 The Status of DOE ATT Capabilities}

What specific capabilities are currently available to DOE (at various levels) to support the use of ATT?

Several pockets within DOE were surveyed as part of this study (i.e., CTA, plans for ETTC, WHC, WSRC, Lockheed Idaho Technologies Co.) But far more is happening than is indicated by these activities. A DOE-specific study, gathering details of what activities and ATT is already being use, needs to be performed before extensive plans can be made. 


\section{Subtopic 4.5 Required Infrastructure Improvements to Facilitate ATT Usage}

What additional infrastructure should be put in place to facilitate future use of ATT?

This question really cannot be answered until the answers to the previous questions are better known. Certainly, as answers emerge, various scenarios can be proposed and then evaluated as more and more solid data are obtained.

\section{Subtopic 4.6 Organizational Changes Needed to Foster ATT}

What organizational changes (management, structures, culture, etc.) are needed to facilitate future use of ATT?

Precise answers to this question are not really possible until the answers to questions in Subtopic 4.3 and 4.4 are better known. However, the current best estimate using the GARTH model would indicate that a great deal more attention should be paid immediately to improving the processes, Department-wide. At first, this would undoubtedly be resented and resisted by field offices that are used to local control. Other imported cultural changes will be possible (and have already started) that will help DOE become an improved learning organization. As answers emerge, various scenarios can be proposed and then evaluated as more and more solid data is obtained.

\section{Subtopic 4.7 Availability of Cost and Benefit Data within DOE}

What cost data is currently available within the DOE to use in cost-benefit analyses?

This report is unable to address this question. While DOE is collecting current cost-oftraining statistics both Department-wide and site-wide, these numbers may or may not be at the level of detail needed to make ATT-related decisions. Certainly, as the ETTC and other efforts continue, efforts should be made to gather cost data that can be used in further analyses, and as will be recommended later, a special function for analysis of cost-effectiveness and cost-benefit analyses should be created within HR-2. 


\section{TOPIC 5. FINAL RECOMMENDATIONS}

This last topic is similiar to the grand total of a huge spreadsheet. Its purpose is to take the essence of all the generic information presented about ATT (the knowledge about the surveyed organizations and all twenty of the lessons learned; the key principles and points regarding media selection methods, cost-benefit analysis approaches, models of readiness and acceptance of technology, proposed blueprints for creating central training functions and training centers; and the specifics that are known or hypothesized about DOE's current status and needs) and create a short list of specific and realistic recommendations for the next steps.

\section{Subtopic 5.1 Specific Recommendations}

Given what has been learned (i.e., types and considerations about ATT, lessons from the surveyed organizations using ATT, example processes for selecting and evaluating the costeffectiveness and readiness for ATT, and DOE's present status), what are some specific tactical and strategic next steps that should be taken by DOE?

1. As indicated in Subtopic 4.3, complete a thorough needs analysis to obtain lists of the needs and problems of the Department that can be solved with ATT.

2. Complete a strategic plan for the centralized function (HR-2) and the Energy Technical Training Center.

3. Customize a media/method selection model (guide, procedure, etc.). Specific recommendations for tailoring the Air University Guide are presented in Subtopic 3.2.

4. Establish a cost-effectiveness and cost-benefit function within the Department. Assign those responsible to gather cost and effectiveness data, process evaluation data, and to create and run cost-benefit models.

5. Promote the learning of ATT terminology and considerations by DOE HR-2 staff. Specific means for introducing novices to this area are discussed in Subtopic 1.5.

6. Designate one or two individuals at Headquarters to become long-term experts in this area. Provide them with sufficient budget to obtain the current newsletters, magazines, and to attend the top three or four conferences each year (see Subtopic 1.5). Also provide them with a budget to visit world-class facilities, hire consultants, and attend workshops. Have these individuals report annually on expected ATT conditions 2, 5 and 10 years out. These future reports will provide the Department with important data for tactical and strategic planning. 
7. Establish an ATT test-bed with the mission of trying out or coordinating and overseeing experimental and prototype efforts in ATT throughout the Department. This function should be cross-departmental and have ties with DOD and other advanced agencies to allow free interchange of lessons learned. Ties with the leading corporate entities and academic institutions will also greatly leverage the money spent.

8. Complete an assessment of ATT within DOE (expanding beyond that which this study uncovered). Continue and increase efforts to collect, consolidate, integrate, and coordinate existing resources (especially those using ATT, so that all products will interchange) that are high quality, accessible, and nonredundant. The mission of the HR-2 or ETTC should be expanded to perform this vital function.

9. As soon as possible, create a master plan for distance learning and network connectivity. A rapid, high-level assessment of departmental needs may be necessary to enable solid infrastructure decisions to be made. Once key elements of a system-wide strategy are clear, start to build the infrastructure for those elements.

10. Promote systems thinking, organizational learning, and a long-term developmental approach to problem-solving in education and training. Reason about the possible implications of the growth curves related to the GARTH model and assumptions presented in Subtopic 3.4 and accept the need to foster slow but sure changes rather than quick but shaky ones.

11. Seek to identify performance needs that can be better met with tools and methods other than training (e.g., electronic performance support systems.)

12. Empower individuals to take responsibility for their own learning and competence by making learning resources more widely available and emphasizing professionalism and lifelong learning.

\section{Subtopic 5.2 Conclusions}

This study is of real value to DOE in understanding ATT and appreciating the various options that are available. It is hoped that the above recommendations are taken seriously and lead to immediate action plans so the power of ATT can be effectively hamessed in helping DOE solve its performance and training-related problems. 


\section{REFERENCES}

Abernathy, J., "The Internet: How To Get There From Here," PC World, Volume 13, No. 1, January 1995, pp. 130-146.

Ager, T., "Offline Placement Testing in Mathematics and Chemistry," Journal of ComputerBased Instruction, Volume 20, No. 2, Spring 1993, pp. 52-57.

Aiken, M.W., "Using a Group Decision Support System as a Teaching Tool.," Journal of Computer-Based Instruction, Volume 19, No. 2, Summer 1992, pp. 82-85.

American Systems Corporation, Distance Learning Cost-Benefit Analysis, published by the Office of Training and Higher Education of the Federal Aviation Administration, December 17, 1993.

Armstrong, L., D. Jones-Yang, and A. Cuneo, "The Learning Revolution," Business Week, February 28, 1994, pp. 80-88.

ASTD National Technical and Skills Training Conference Proceedings, American Society For Training and Development, Alexandria, VA, October 1992.

Barron, A. E. and G. W. Orwig, New Technologies for Education, Englewood, Colorado: Libraries Unlimited, Inc., 1993.

Branson, R.K., "Why the Schools Can't Improve the Upper Limit Hypothesis," Journal of Educational Development, Volume 10, No. 4, 1987, pp. 15-25.

Brey, Ronald, U.S. Postsecondary Distance Learning Programs in the 1990s. Washington, DC., Instructional Telecommunications Consortium.

Burger, J., The Desktop Multimedia Bible, Reading, Massachusetts: Addision-Wesley Publishing.

Burlbaw, L.M., "Supporting Teacher Education with Computer-Based Telecommunications Systems," Journal of Educational Technology Systems, Volume 22(2), 1993-94, pp. 99-112.

Campbell, J.O., and A.S. Gibbons, "Progressively Challenging Evaluative Simulations That Provide Assessment, Learning and Performance Support," Journal of Instruction Delivery Systems, Spring 1994, pp. 25-28.

Campbell, J.O., C. A. Lison, T. K. Borsook, J. A. Hoover, and P. Arnold, Reducing Instructor Time to Train Problem Solving Facilitators Using Computers and Video, Nashville, TN., 1993, Peabody College of Vanderbilt University. 
Carnevale, A.P., L. J. Gainer, and J., Villet, Training in America: The Organization and Strategic Role of Training, San Francisco, CA., 1990, Jossey-Bass Inc.

Cates, W.M., "Fifteen Principles for Designing More Effective Instructional Hypermedia/Multimedia Products," Educational Technology, December 1992, pp. 5-11.

Chapman, B.L., Multimedia Simulations: Low-Cost, PC-Based Scenarios that Teach Novices to Think Like Experts, Technical Paper: 1994, Allen Communication.

Chen, L.C., "Interactive Video Technology in Education: Past, Present and Future," Journal of Educational Technology Systems, Volume 19(1), 1990-91, pp. 5-19.

Chin, Keric B. O., Introduction to Training Decisions Modeling Technologies: The Training Decision Systems, (AL-TP-1992-0014), Brooks AFB, TX: April 1992, Armstrong Laboratory.

Clark, Developing Technical Training: A Structured Approach for the Development of Classroom- and Computer-Based Instructional Materials, 1989.

Cognition and Technology Group of Vanderbilt, "The Jasper Experiment: An Exploration of Issues in Learning and Experimental Design," Educational Technology Research and Development, Volume 40, No. 1, pp. 65-80.

Computer Assisted Medical Interactive-Video System, Catalog of Productions, 11 January 1994.

Coleman, M., "Hypertext in the Humanities Classroom," Education, Volume 113, No. 3, pp. 392-398.

Cox, M.J., "The Computer in the Science Curriculum," in Whitaker, K.S., The Restructuring Handbook: A Guide to School Revitalization, Needham Heights, Massachusetts, pp. 19-35, 1994, Allyn and Bacon.

DAU Remote Learning Feasibility Assessment, Field Research Report, Alexandria, VA, 1994, Walcoff.

Davie, L.E. and R. Wells, 1990, "Instructional Design in CMC: Maximizing the Potential of the Learner and the Medium." Unpublished manuscript, 1990.

Davis, S., 1990, "Distance Education in Higher Education: Lessons Learned and Challenges Ahead," Proceedings of Sixth Anmual Conference on Distance Teaching and Learning, Madison, WI, 1990. 
Dennis, V.E. and D. Gruner, "Computer Managed Instruction at Arthur Andersen \& Company: A Status Report," Educational Technology, pp. 7-16, March 1992,.

DeVoney, C., "The Unwired Nation," Windows Sources, pp. 106-138, April 1994.

Dijkstra, S., H. P. M. Krammer, and J. J. G. Van Merrienboer, Instructional Models in Computer-Based Learning Environments, 1993, New York: NATO Scientific Affairs Division.

Distance Learning Curriculum Analysis \&Media Selection, Air University, Maxwell Air Force Base, 1994.

Durham, L.B., Use of Technology Delivered Instruction in the Nuclear Industry, paper presented at the American Nuclear Society Annual Meeting in New Orleans, LA, June 20, 1994, Updated August 8, 1994.

Drucker, P.F., "The New Society of Organizations," Harvard Business Review, pp. 95-104, September-October 1992.

Ellis, H.D., "Application Report: Low-cost, High-volume Exploitation of Computer Technology in Education," Journal of Computer-Based Instruction, Volume 19, No. 3, pp. 73-76, Summer 1992 .

Ellis, J. E., "Roger Schank Wants Your Child's Mind," Business Week, pp. 74-75, July 18, 1994.

ETOILE: Experimental Tool Box for Interactive Learning Environments, User Mamual, 1992, Release 1.0, TECFA: University of Geneva, November 1992.

Eugenio, V. and E. Habelow, "Is All Multimedia Created Equal? Differentiating Between Four Types of Multimedia Products," Journal of Instruction Delivery Systems, pp. 20-24, Winter 1994.

Fred Meyer, Inc., "Reasons for IBM Multimedia Training," Multimedia Today, The Sourcebook for Multimedia, Volume II, No. 1, pp. 46-49, 1994.

Gagné, R. M., R. D. Tennyson, and D. J. Gettman, (Eds.), Designing An Advanced Instructional Design Advisor: Conceptual Frameworks, (AL-TP-1991-0017-Vol-5), 1994, Brooks AFB, TX: Armstrong Laboratory, Human Resources Directorate.

Galagan, P. A., "IBM Gets Its Arms Around Education," Training and Development Journal, pp. 35-41, January 1989, American Society For Training and Development, Alexandria, VA. 
Galbreath, J., “The Education Buzzword of the 1990's: Multimedia, or Is It Hypermedia, or Interactive Multimedia, or . . ?" Educational Technology, pp. 15-19, April 1992.

Gery, Gloria J., Electronic Performance Support Systems, 1991, Wingarten Publications, Boston.

Gery, Gloria J., Making CBT Happen, 1987, Wingarten Publications, Boston.

Gill, B.J., W. L. Dick, R. A. Reiser, and J. E. Zahner, "A New Model for Evaluating Instructional Software," Educational Technology, pp. 39-44, March 1992.

GPU Nuclear Corporation, "DVI Training at Three Mile Island," Multimedia Today, The Sourcebook for Multimedia, Volume II, No. 1, pp. 51-57, 1994.

Gronlund, N. E., Stating Objectives for Classroom Instruction, 1995, Third Edition, New York: MacMillan Publishing Company.

Guthrie, B.M. and M. McPherson, "The Efficacy of a Customized Approach to Computer Assisted Instruction," Journal of Computer-Based Instruction, Volume 19, No. 3, pp. 100-104, Summer 1992.

Haber, L., "Live From Your Conference Room," Midrange Systems, Volume 5, No. 24. December 22, 1992, Professional Press, Inc.

Hannafin, M. J., "Emerging Technologies, ISD, and Learning Environments: Critical Perspectives," Educational Technology Research and Development, Volume 40, No. 1, pp. 49-63.

Hannafin, M. J., and K. L. Peck, The Design, Development, and Evaluation of Instructional Software, 1988, New York: MacMillan Publishing Company.

Hansen, E. J., "Interactive Video for Reflection: Learning Theory and a New Use of the Medium," Educational Technology, pp. 7-15, July 1989.

Harris, M. C. (Capt., USAF), "An Approach for the Distance Learning of AFIT/LS Resident Degree Curricula," Thesis: AFIT/GIR/LSR/910-9, 1992.

Hayes and Singer, Simulation Fidelity in Training System Design: Bridging the Gap Between Reality and Training, 1992.

Heathman, D. and B. Kleiner, "Training and Technology: The Future is Now," Training and Development, 1991, American Society For Training and Development, Alexandria, VA. 
Heller, N., Educational Technology and Telecommunications from a Cost Accountant's Perspective, presented at the Society for Applied Learning Technology Conference, February 24, 1994.

"Hewlett-Packard's Distance Leaming Facility Promotes Student Interaction" Presentation Products Magazine, p. 18, March 1993.

Hill, J. V., 1989, "The Design and Procurement of Training Simulators," Educational Technology, pp. 26-27, May 1989.

Hmelo, C. E., "Computer-Assisted Instruction in Health Professions Education: A Review of the Published Literature," Journal of Educational Technology Systems, Volume 18(1), pp. 83-101, 1989-90.

Hooper, Simon, "Cooperative Learning and Computer-Based Instruction," Educational Technology Research and Development, Volume 40, No. 3, pp. 21-38.

InfoTech DOE Technical Information Meeting Proceedings, U.S. Department of Energy Office of Scientific and Technical Information, Oak Ridge, TN, October 1994.

Interservice/Industry Training Systems and Education Conference (I/ITSEC) Conference Proceedings, National Security Industrial Association, Washington, D.C., November 1994.

International Distance Learning Conference (IDLCON) Proceedings, United States Distance Learning Association, Washington, D.C., March 1994.

Jensen, R. P., An Interface for Technology in the Classroom, 1995, Utah State University 5th Annual Summer Instructional Technology Institute, Utah State University, Logan, UT.

Johnston, J., Electronic Learning: From Audiotape to Video Disc, 1987, Englewood Cliffs, NJ: Lawrence Erlbaum Associates.

Johnston, W. B. and Norton, J. E., "Modeling Student Performance in Diagnostic Tasks: A Decade of Evolution," Educational Technology Research and Development, Volume 40, No. 4, pp. 81-93.

Janassen, Designing Structured Hypertext and Structured Access to Hypertext, 1988.

Janassen, Instructional Designs for Microcomputer Courseware, 1988.

Jones, M. J. and D. J. Kane, "Application Report: Network Use in Central Management of Large University Physics Course," Journal of Computer-Based Instruction, Volume 19, No. 3 , pp. 77-81, Summer 1992. 
Kenworthy, N. W, A. Zuk, and R. D. Griffith, "Multimedia Training is Saving Money for American Companies: Case Studies," The Video Disc Monitor, February 1990.

Kozma, R.B., "Learning with Media," Review of Educational Research, Volume 61, No. 2, pp. 179-211, Summer 1991.

Kowalski, R. "Computer Conferencing in the English Composition Classroom," Educational Technology, pp. 29-32, April 1989.

Kulvicki, Dennis M., Introduction to Multimedia Learning Systems, presented at the Society for Applied Learning Technology, February 22, 1994.

Kulvicki, Dennis M., Designing, Developing and Managing Effective Multimedia Learning Centers, presented at the Society for Applied Learning Technology, February 22, 1994.

Lacy, M. J. and R. K. Wood, "A Model of an Expanded-Frame Hypermedia Knowledge-Base for Instruction," International Journal of Instructional Media, Volume 20(3), pp. 207-213, 1993.

Lai, P., "Interactive Video Courseware: Problems, Issues and Practical Implications," Journal of Educational Technology Systems, Volume 18 (4), 1989-90, pp. 313-323.

Lanier, L. and R. Rathe, "Teaching Radiologic Anatomy Using Interactive Technologies: A Student-Centered Approach," Journal of Medical Education Technologies, pp. 4-9, Winter 1994.

Lawler and Yazdami, Artifical Intelligence and Education, 1987.

Iearning Technology Center, Peabody College of Vanderbilt University, "From Visual Word Problems to Learning Communities: Changing Conceptions of Cognitive Research," in McGilly, K. (Ed.), Classroom Lessons: Integrating Cognitive Theory and Classroom Practice. Cambridge, MA: MIT Press/Bradford Books.

Leiblum, M. D., "A Media Selection Model Geared Toward CAL," Technological Horizons in Education, Volume 7, No. 2, pp. 29-33, 1980.

Levin, H. M., Cost-Effectiveness, A Primer, New Perspectives In Evaluation, Volume 4, 1985 Beverly Hills, CA: Sage Publications.

Levine, T. K., "Teaching Telecourses: Opportunities and Options, A Faculty Handbook," Washington, DC. 1987, Anneberg/CPB Project/PBS Adult Learning Service. 
$\mathrm{Li}, \mathrm{Z}$., "Reducing Multimedia CBT Development Time Using Transaction Shells," presentation at Utah State University Summer Institute, August 1993.

Liao, T. T. "Special Report: Advanced Educational Technology: A Five Year Program of the NATO Science Committee," Journal of Educational Technology Systems, Volume 18(1), 1989-90, pp. 69-77.

Luskin, B. J., "CD-I From Boob Tube to Teacher's Assistant-The Birth of Smart TV," Journal of Instruction Delivery Systems, pp. 3-5, Winter 1993.

Lyons, C., Audio for Distance Learning, 1973, self-published by Shure Brothers, Inc.

Manager's Guide to New Training Technologies, 1989, Institute for Simulation and Training, University of Central Florida.

Marlino, Mary R., Evaluating Interactive Multimedia, presented at the Society for Applied Learning Technology, February 22, 1994.

Mengel, C., Designing Interactive Multimedia, presented at the Society for Applied Learning Technology, February 22, 1994.

Mosterman, P. J., M. A. M. Dorlandt, J. O. Campbell, C. Burow, R. Bouw, A. J. Brodersen, and J. R. Bourne, Virtual Engineering Laboratories: Design and Experiments, 1994, Nashville, TN: Peabody College of Vanderbilt University.

"MPC Level 2 Announced, IBM Aboard," Multimedia \& Video Disc Monitor, Volume XI, No. 6, June 1993.

Newman, E. K., HyperModeling: A Strategy for Constructing and Accessing Knowledge, Cambridge, Massachusetts: BBN, Inc.

Noel, J. and D. Carnine, "Group and Individual Computer-Assisted Video Instruction" Educational Technology, pp. 36-37, January 1989.

Nuccio, E. J., "The Next Generation of Teachers: Past Skills, Future Models," Journal of Educational Technology Systems, Volume 18(4), pp. 279-293, 1989-90.

Office of Technology Assessment, "Linking For Learning: A New Course for Education" Washington, D.C., U.S. Government Printing Office.

Okolica, C. and C. M. Stewart, 1994, "Voice Mail and Academics: Creating a Virtual Office," Journal of Educational Technology Systems, Volume 22(2), pp. 113-121, 1993-94. 
Orlando Multimedia '94 Conference Proceedings, Society For Applied Learning Technology, Warrenton, VA, February 1994.

Pence, H. E., "Combining Cooperative Learning and Multimedia in General Chemistry," Education, Volume 113, No. 3, pp. 375-381.

Portway, P. S. and C. Lane, Guide to Teleconferencing and Distance Learning, 2nd Ed., 1994, San Ramon, California, Applied Business TeleCommunications.

Pratt, D. D., "Conceptions of Teaching," Adult Education Quarterly, Volume 42, No. 4, pp. 203-220, Summer 1992.

Pugh, H. L., S. W. Parchman, and H. Simpson, Field Survey of Videoteletraining Systems in Public Education, Industry and the Military, March 1991, San Diego, CA: Navy Personnel Research and Development Center, TR-91-7.

Quinn, J., "Videoconferencing: Face to Face at a Distance," Electrical Power Research Institute Journal, pp.27-33, April/May 1993.

Reiber, L. P., "Computer-Based Microworlds: A Bridge Between Constructivism and Direct Instruction," Educational Technology Research and Development, Volume 40, No. 1, pp. 93-106.

Reid, J. C., and J .A. Mitchell, "The Improvement of Learning in Computer-Assisted Instruction," Journal of Educational Technology Systems, Volume 19(4), pp. 281-289, 1990-91.

Salisbury, D. F., and D. R. Conner, "How to Succeed as a Manager of an Educational Change Project," Educational Technology, pp. 12-18, July-August 1994.

Sawyer, W. D. M., "The Virtual Computer: A New Paradigm for Educational Computing," Educational Technology, pp. 7-14, January 1992.

Schlecter, T. M., Bessemer, D.W. and K.P. Kolosh, "Computer-based Simulation Systems and Role-Playing: An Effective Combination for Fostering Conditional Knowledge," Journal of Computer-Based Instruction, Volume 19, No. 4, pp. 110-114, Autumn 1992.

Sheather, G., R. Martin, and D. Harris, "Partners in Excellence: A New Model for Cooperative Education," ETII, Volume 30, No. 1, pp. 5-31.

"Simulators, Modeling and Training: 1993 International Conference Proceedings," hosted by Energy Services in New Orleans, LA., November 16-18, 1993. 
"Software Reviews: Hands-On Simulation, Electronic Learning, pp. 34-35, March 1993.

Solomon, J., "Mr. Vision, Meet Mr. Reality," Newsweek, pp. 62-89, August 16, 1993.

Spector, J. M., Designing and Developing An Advanced Instructional Design Advisor (AFHRLTP-90-52), 1990, Brooks AFB, TX: Armstrong Laboratory.

Spector, J. M., M. C. Polson, D. J. Muraida, (Eds.), Automating Instructional Design: Concepts and Issues, 1993, Englewood, NJ: Educational Technology.

Spector, J. M., L. K. Whitehead, "A Guided Approach to Instructional Design Advising," ADCIS Conference Proceedings, February 1994.

Spitzer, D. R., J. Bauwens, and S. Quast, "Extending Education Using Video: Lessons Learned," Educational Technology, pp. 28-30, May 1989.

Steinberg, E. R., "The Potential of Computer-Based Telecommunications for Instruction," Journal of Computer-Based Instruction, Volume 19, No. 2, pp. 42-46, Spring 1992.

Suppe, P., "Instructional Computers: Past, Present and Future," in Whitaker, K.S., The Restructuring Handbook: A Guide to School Revitalization, Needham Heights, Massachusetts: Allyn and Bacon, pp. 5-17, 1994.

Sutherland, S., "Fiber Goes the Distance," Electronic Learning, pp. 46-49, September 1993.

Taylor, G. M., W. T. Subalusky, S. Rippon, R. C. Lewis-Clapper, "Special Section: Training," Nuclear News, Volume 36, No. 5, pp. 40-60, April 1993, American Nuclear Society, La Grange, II.

Telecommunications for Learning, Volume III, The Educational Technology Anthology Series, Library of Congress Educational Technical Publications, January 1991.

The Going the Distance Advisory Group, "The Distance Learning Degree Project," A Report to the Public Broadcasting Service - Adult Learning Service, March 23, 1994.

Thomas, T. K., Using Cognitive Simulations in Multimedia for Maintenance Troubleshooting Training: Practical, Cost-effective Simulations, Salt Lake City, UT: Allen Communications, Inc., 1994.

TRADOC Regulation No. 350-7, 1988, Systems Approach to Training, Fort Monroe, VA: Dept. of the Army, February 26, 1988. 
Training Resource and Data Exchange (TRADE) Conference Abstracts, Oak Ridge Institute for Science and Education, Oak Ridge, TN, November 1994.

U.S Air Force Handbook 36-2235, Volume 4, 1994, Information for Designers of Instructional Systems, Washington, D.C.: United States Department of the Air Force, February 1994.

U.S Air Force Manual 50-62, Training Handbook for Air Force Instructors, Washington, D.C.: United States Department of the Air Force.

U.S. Department of Energy, 1991, TAP 2: Performance-Based Training Manual, DOE/NE-0102T.

U.S. Department of Energy Safeguards and Security Central Training Academy, 1994, Distance Learning Operations Plan, Version 1.2, February 23, 1994.

Wells, R., R. H. Phelps, D. F. Haggard, and J. H. Hiller, Computer-Mediated Communications for Distance Education and Training: Literature Review and International Resources, Alexandria, VA: U.S. Army Research Institute for the Behavioral and Social Sciences, January 1991, Research Product 91-06.

Wiggenhom, B., "Motorola University: The Role of the Industrial University," presented at the National Society for Performance and Instruction Chicago Business Forum, April 12-16, 1993.

Williamson, M., "High Tech Training," Byte, pp. 74-88, December 1994.

Winn, W. and W. Bricken, "Designing Virtual Worlds for Use in Mathematics Education: The Example of Experiential Algebra," Educational Technology, pp. 12-19, December 1992.

Xenakis, J. J., "Videoconferencing: Smile You're on Corporate Camera," Corporate Communicating, Volume 2, No. 2, February 1993, Ziff-Davis Publishing Company.

Yang, Y., "The Effects of Media on Motivation and Content Recall: Comparison of Computerand Print-Based Instruction." Journal of Educational Technology Systems, Volume 20(2), pp. 95-105, 1991-92.

Yourdon, E., Decline and Fall of the American Programmer, 1992, Englewood Cliffs, New Jersey.

Zemke, R., "Shell Scores with Interactive Video," Training, pp. 33-38, September 1991.

Zuckerman, M. R., L. J. Hatala, Incredibly American, Milwaukee, Wisconsin, 1991, ASQC Quality Press. 


\title{
APPENDIX A \\ MEDIA SELECTION SURVEY INSTRUMENTS
}

\author{
Excerpt from \\ Distance Learning Curriculum \\ Analysis \& Media Selection
}

Produced By

Air University

Maxwell Air Force Base

A-1 


\title{
SECTION I
}

\section{SURVEY INSTRUMENTS}

\author{
Introduction
}

Section I of this package consists of four different surveys; however, you only need to complete those that apply to your course or program.

The first is the Resident Course Survey. It asks basic questions about a course such as the number and type of students attending. Complete this survey for each resident course.

The Resident Course Analysis Worksheet will provide detailed information about course objectives and the methodologies used to meet them. This information is critical when determining whether or not a course or a significant portion of it can be converted into a DI format. Instructions for completing the worksheet are included. Complete this worksheet for each resident course that does not have a nonresident program.

The Media Selection Guide Worksheet should be completed for each resident course that does not have a nonresident program. Several media possibilities, as well as instructional design characteristics, are listed on the worksheet. It is your responsibility to decide how important these characteristics are for your course. Through a simple weighing process, you will see which media are the most likely candidates for exporting your course. Additional information about these media is included in Section II of this package.

The last survey in the package is the Nonresident Programs Survey. It is intended to provide preliminary data about our present distance learning efforts and how we might enhance them collectively in the future. Complete this survey for each nonresident course. 


\section{RESWDENT COURSE SURVEY (GENERAL)}

COURSE TITLE:

DATE
COMPLETED BY: DUTY TITLE/TELEPHONE:

INSTRUCTIONS: Either circle the appropriate response, write your answer in the space provided, or use the comments section, Part D:

\section{A. Importance of Program}

1. Is this course, or any part of it, mandated by law or regulation? (If yes, please note details in the Comments section.)

2. Is this course mandated to be taught in residence? (If yes, please cite source in Comments section.)

3. Is this course, or any part of it, required for job assignment? (If yes, please cite source in Comments section.)

4. Is this course, or any part of it, necessary for upgrade or promotion? (If yes, please cite source in Comments section.)

5. Is this course, or one similar to it, offered elsewhere in the government or private sector? (If yes, please note details in the Comments section.)

6. Does this course presently have a parallel nonresident course? (If yes, please note details in the Comments section.)

7. Are the objectives, or student learning outcomes, for the nonresident programs the same as those for the resident course? (If no, please note details in the Comments section.)

8. Most students complete prerequisite courses prior to attending this resiclent course?

\begin{tabular}{|l|l|l|}
\hline Yes & No & N/A \\
\hline Yes & No & N/A \\
\hline Yes & No & N/A \\
\hline Yes & No & N/A \\
\hline Yes & No & N/A \\
\hline Yes & No & N/A \\
\hline Yes & No & N/A \\
\hline Yes & No & N/A \\
\hline
\end{tabular}

B. Student Load Characteristics

1. How often is this course offered during the academic year?

2. How many students graduate from the course each academic year?

Resident Nonresident

3. What are the minimum and maximum class sizes accepted?

4. What percentage of students on an academic year basis are:

Active Duty AF

Active Duty Marine

Civilian - Active Duty Army ; National Guard ; International - Active Duty Navy ; Reserve

; CAP _ Reserve ?

5. Is there a backlog or waiting list of students for this course? (ff yes, explain in the comments section.)

6. Do you foresee a potential backlog of students in the future? (If yes, explain in the Comments section.)

\begin{tabular}{|l|l|l|}
\hline Yes & No & N/A \\
\hline Yes & No & N/A \\
\hline
\end{tabular}




\section{General Course Characteristics}

1. Is any part of this course classified secret or higher? If "yes, " what level?

2. Does this course require special resources, i.e., library, equipment, facilities? (If yes, please note details in Comments section.)

3. What is this course's present length (academic contact time only)?
(a) $8-24 \mathrm{hrs}$
(b) $25-40 \mathrm{hrs}$
(c) $41-80$ hrs
(d) $81-160 \mathrm{hrs}$
(e) $161+$ hrs

4. How frequently does the course content change?
(a) twice a year or more (b) once a year
(c) every 2 years
(d) every 3 years

5. What percentage of the course changes during that time?

6. For what reasons does the course most often require changes?
(a) changes in regulations
(b) changes in applicable technology
(c) changes in focus or mission goals
(d) changes to improve quality
(e) changes to ensure currency of information

7. Does this course have any objectives in the psychomotor domain? (See Appendix A) (If yes, please note them in Comments section.)

8. Does this course have any objectives in the affective domain? (See Appendix A) (If yes, please note them in Comments section.)

9. What percentage of course instructional objectives are (see Appendix A) Knowledge level?

Comprehension level?

Application level?

Higher?

10. How many instructional hours involve lectures given by guest speakers requiring TDY payment and travel reimbursements?

11. Do you formally evaluate your students? (If yes, which evaluation (s) do you use? Written Oral Other ; Observation of Performance ;)

D. Comments 


\section{INSTRUCTIONS FOR \\ RESIDENT COURSE ANALYSIS \\ WORKSHE]ET}

General instructions: This worksheet should be completed by the course director or a faculty member knowledgeable about the course objectives and current instructional methodology, DO NOT complete this worksheet if the course already is in a nonresident format. Make additional copies as necessary.

STEP 1: Decide whether to list course objectives by topical category or in the sequence currently taught in the resident program. For example, if your course catalog/syllabus lists together all objectives related to "leadership" but in actuality these objectives are taught at various times throughout the course, you must decide how best to list these objectives for distance learning (DL).

Use the following criteria to make your decision:

A. List each objective in the sequence taught in the resident program if, in your opinion, that sequence should be maintained in a DL version of the course.

B. List objectives by category if, in your opinion, these categories should be developed as stand-alone modules for DL.

STEP 2: Number each course objective in proper order based on the decision you made in STEP 1 , making sure each objective is assigned a different number. For example, a course with fifty objectives would begin with " 1 " and end with "50." Indicate the numbers in Column 1.

STEP 3: Write each course objective in the space provided in Column 2 or reference each objective to a course syllabus or lesson plan (attach a copy of the document to the worksheet). Make sure the objective corresponds with the objective number indicated in the previous column.

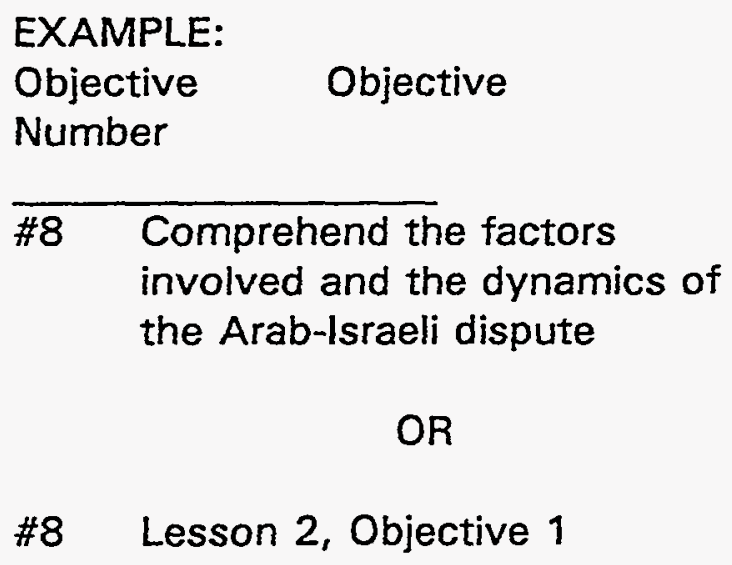


STEP 4: In Columns 3 and 4, indicate the highest cognitive level and/or the highest affective level of learning attained for each objective by writing the corresponding numerical value shown in Appendix A, Levels of Learning.

STEP 5: In Column 5, indicate the instructional methodology(ies) currently used in the classroom to teach each objective. This refers to the actions taken to help students learn the material and meet the objective. Select the term from Appendix B, Instructional Delivery Methods, that best describes what usually takes place in the typical running of the course. Include all methods used for each objective.

Write the terms in the space provided. Use other terminology ONLY if the terms in the appendix do not adequately describe a method you use.

STEP 6: Use Column 6 to describe anything, specific to an objective, that might affect a decision to convert to DL. For example, if course materials related to an objective are subject to frequent changes, if guest speakers from outside the command are used, if extensive research is required, etc.

STEP 7: Cluster the objectives that must be taught together as a block by drawing a bracket " $\{$ " in the left margin.

STEP 8: Number pages. 
RESIDENT COURSE ANALYSIS WORK SHEET

Lesson Number Organization/School

Lesson Title

Page of

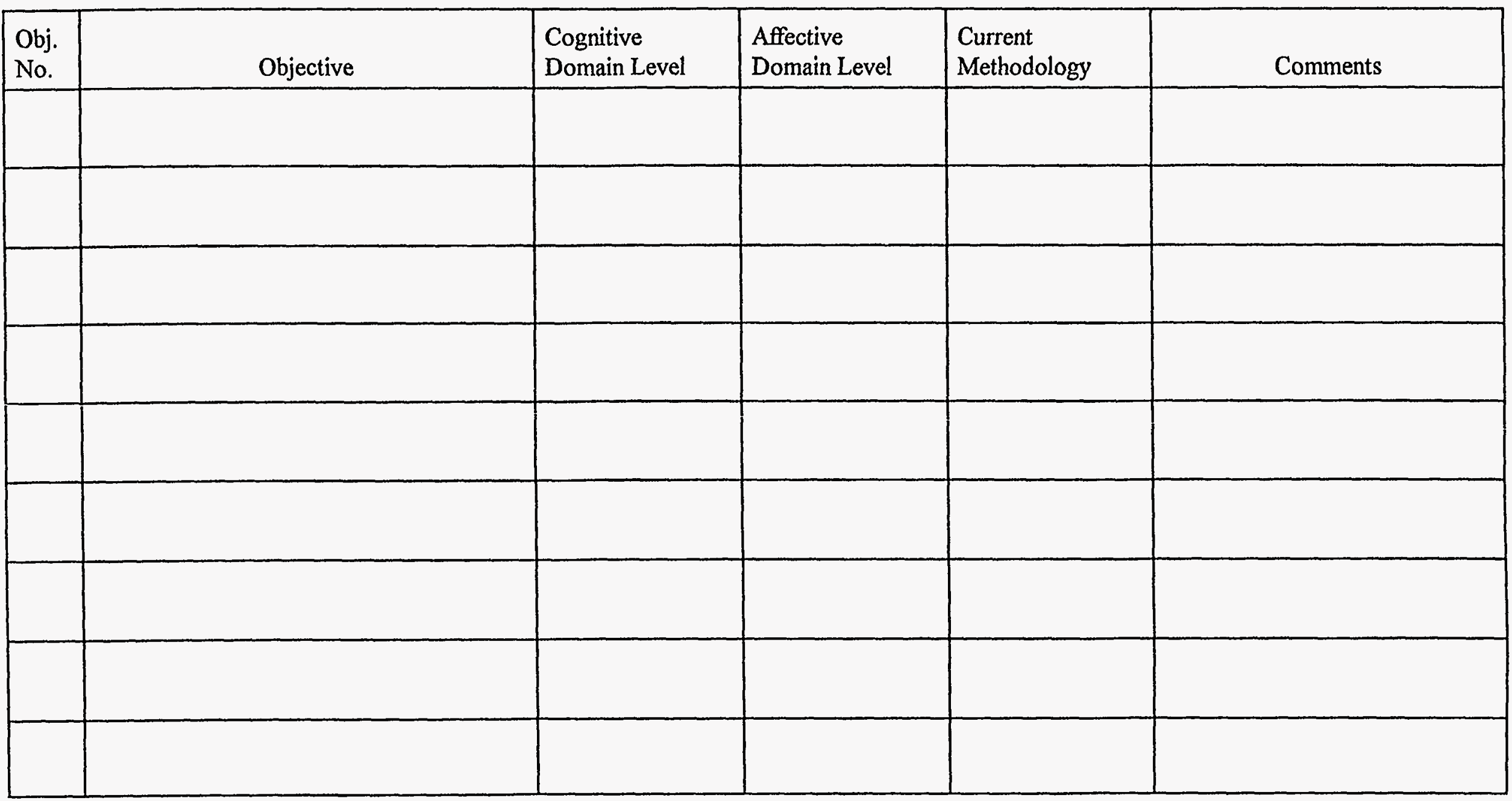

- Adapted from Harris, Mark C. (Capt., USAF), "An Approach for the Distance Learning of AFIT/LS Resident Degree Curricula," Thesis: AFIT/GIR/LSR/910-9 


\section{APPENDIX A}

Leveis of Learning*

\begin{tabular}{|l|c|l|}
\hline \multicolumn{1}{|c|}{ COGNITIVE DOMAIN } & CODE & \multicolumn{1}{c|}{ AFFECTIVE DOMAIN } \\
\hline $\begin{array}{l}\text { Knowledge } \\
\text { Recall and Recognition }\end{array}$ & 1 & $\begin{array}{l}\text { Receiving } \\
\text { Being aware; attending willingly or selectively }\end{array}$ \\
\hline $\begin{array}{l}\text { Comprehension } \\
\text { Understanding; translation, interpretation, } \\
\text { extrapolation }\end{array}$ & 2 & $\begin{array}{l}\text { Responding } \\
\text { Complying; acting willingly }\end{array}$ \\
\hline $\begin{array}{l}\text { Application } \\
\text { Use of learned material in specific instances }\end{array}$ & 3 & $\begin{array}{l}\text { Valuing } \\
\text { Accepting a value for its perceived worth; } \\
\text { appreciation }\end{array}$ \\
\hline $\begin{array}{l}\text { Analysis } \\
\text { Understanding of organizational structure; } \\
\text { interrelationships }\end{array}$ & 4 & $\begin{array}{l}\text { Organizing } \\
\text { Comparing, relating, synthesizing values into } \\
\text { one's own system }\end{array}$ \\
\hline $\begin{array}{l}\text { Synthesis } \\
\text { Creation of new structures/relationships }\end{array}$ & 5 & $\begin{array}{l}\text { Characterizing } \\
\text { Integrating values into life style }\end{array}$ \\
\hline $\begin{array}{l}\text { Evaluation } \\
\text { Value judgements }\end{array}$ & 6 & \\
\hline
\end{tabular}

*Educational taxonomies based on Bloom [mental activity in cognitive domain] and Krathwohl [state of mind in affective domain]

NOTE: The psychomotor domain is concerned with motor skills. Although this domain includes some learning outcomes that are common to most subjects (writing, speaking, laboratory skills), it receives major emphasis in commercial subjects, health sciences, technical training, industrial education, physical education, and the performing arts. Performance skills play a prominent role in the instructional objectives in these areas. Gronlund, Norman E. (1985), Stating Objectives for Classroom Instruction, Third Edition, New York; Macmillan Publishing Company. (35) 


\section{APPENDIX B}

Instructional Delivery Methods*

USE THIS CHART TO COMPLETE STEP 5, RESIDENT COURSE ANALYSIS WORKSHEET

\begin{tabular}{|c|c|}
\hline METHOD & DEFINTTION \\
\hline ASSIGNED READING & $\begin{array}{l}\text { Printed materials such as books, regulations, articles, } \\
\text { and handouts; reading may be assigned or suggested } \\
\text { reading. }\end{array}$ \\
\hline CASE STUDY & $\begin{array}{l}\text { A carefully designed description of a situation, } \\
\text { designed specifically to provide systematic analysis } \\
\text { and discussion. }\end{array}$ \\
\hline DEMONSTRATION & $\begin{array}{l}\text { Presentation or portrayal of a sequence of events (by } \\
\text { the instructor or expert) to show a procedure, } \\
\text { technique, or operation; usually accompanied by an } \\
\text { oral explanation; may be direct or indirect. }\end{array}$ \\
\hline FIELD TRIPS & $\begin{array}{l}\text { Organized visits or tours related to subject matter. } \\
\text { Usually designed to give students a "sense" of a real- } \\
\text { life situation or to show an example of application. }\end{array}$ \\
\hline GUIDED DISCUSSION & $\begin{array}{l}\text { An instructor-controlled, peer-interactive process of } \\
\text { sharing information and experiences related to } \\
\text { achieving an objective. }\end{array}$ \\
\hline INDIRECT DISCOURSE & $\begin{array}{l}\text { Verbal interaction among two or more people which } \\
\text { is heard by the students; may be a dramatization, such } \\
\text { as role playing, or dialogue between panel members. }\end{array}$ \\
\hline $\begin{array}{l}\text { LECTURE: } \\
\text { a. Instructor } \\
\text { b. Guest Speaker } \\
\text { c. Student Presentation } \\
\text { d. Audio Tape } \\
\text { e. Film or Video Tape }\end{array}$ & $\begin{array}{l}\text { A formal or semi-formal oral presentation either } \\
\text { directly or indirectly (as in a recording). }\end{array}$ \\
\hline NON-DIRECTED DISCUSSION & $\begin{array}{l}\text { Peer-controlled free discussion. Usually } \\
\text { recommended for receiving and responding to lower } \\
\text { levels of affective material. }\end{array}$ \\
\hline PERFORMANCE & $\begin{array}{l}\text { Student interactions with equipment/persons/data } \\
\text { and/or student demonstrations of } \\
\text { procedures/processes to attain objectives or show } \\
\text { proficiency; direct observation of students required. }\end{array}$ \\
\hline
\end{tabular}

*AF Manual 50-62, Training Handbook for Air Force Instructors. 


\begin{tabular}{|l|l|}
\hline \multicolumn{1}{|c|}{ METHOD } & \multicolumn{1}{|c|}{ DEFINITION } \\
\hline PRACTICAL EXERCISES & $\begin{array}{l}\text { Instructor-designed activities to allow students } \\
\text { (individually or in groups) to apply specific } \\
\text { knowledge; may include drill and practice routines, } \\
\text { quizzes, etc., in which feedback can be direct or } \\
\text { indirect. }\end{array}$ \\
\hline PROGRAMMED QUESTIONING & $\begin{array}{l}\text { An instructor-controlled process used to } \\
\text { systematically demand a sequence of appropriate } \\
\text { student responses. }\end{array}$ \\
\hline QUESTIONING & $\begin{array}{l}\text { An instructor-controlled interactive process used to } \\
\text { emphasize a point, stimulate thinking, keep students } \\
\text { alert, and to check student knowledge or } \\
\text { understanding of material. }\end{array}$ \\
\hline RESEARCH PROJECT & $\begin{array}{l}\text { A student-controlled inquiry or study designed to } \\
\text { solve a problem or investigate an hypothesis; may } \\
\text { include literature searches and reviews, interviews, } \\
\text { and surveys; conclusions and recommendations are } \\
\text { derived. }\end{array}$ \\
\hline SELF-STUDY & $\begin{array}{l}\text { A student-controlled instructional process whereby } \\
\text { the student is responsible for obtaining the } \\
\text { information necessary to achieve the learning } \\
\text { objectives from sources provided or suggested by an } \\
\text { instructional monitor. }\end{array}$ \\
\hline STMULATION/GAMING & $\begin{array}{l}\text { A peer-controlled group interactive process in which } \\
\text { task- or objective-related information and experience } \\
\text { are evoked from the students. }\end{array}$ \\
\hline SEMINAR & $\begin{array}{l}\text { Dynamic student participation in role-playing and } \\
\text { problem solving whereby the students "experience" } \\
\text { various outcomes. }\end{array}$ \\
\hline $\begin{array}{l}\text { The provision by which students are given the } \\
\text { opportunity to search for information, as by } \\
\text { questioning the instructor, tutor, or coach. }\end{array}$ \\
$\begin{array}{l}\text { Question and answer session between the instructor } \\
\text { and a visiting expert following a highly structured } \\
\text { plan. }\end{array}$ \\
\hline TEACHING INTERVIEW
\end{tabular}




\section{INSTRUCTIONS FOR}

\section{MEDIA SELECTION GUIDE WORKSHEET}

\section{General Instructions:}

The attached worksheet will help you tentatively identify appropriate media for exporting your course. Use it as a guide to help you focus on those media that are capable of fulfilling the instructional design requirements of your course. Do not complete this worksheet if the course is already in a nonresident format.

Before you begin, you must make a decision on whether to complete one worksheet for the course as a whole or one for each segment or block of instruction. Use the following criteria to make your decision:

Complete multiple worksheets (one for each block or segment) if any of these are true:

A. The block of instruction is self-contained and of sufficient length (in your opinion) that it could be exported as a separate module independent of the rest of the course.

B. Not all students, or potential students, are required to complete the entire course, but would benefit from particular segments or blocks.

C. The segments or blocks of instruction are managed and/or taught by separate departments whose personnel do not have full knowledge of the requirements of the other blocks or segments.

\section{STEP 1: Determine the importance of each characteristic listed in the left column.}

A. Some of the characteristics on the list will be more important than others for meeting course objectives. Determine the importance of each characteristic on the list on a scale of 0 to 10 , with 0 indicating that the item is of no importance (should not be considered or does not apply) and 10 indicating that the item is absolutely mandatory. For all other items, assign a number between 9 and 1 based on each item's relative importance compared to other items on the list.

B. Write the number (0-10) reflecting your rating of the importance of each item in the "Importance" column. This number will be multiplied by each medium's ability to meet the requirement, resulting in a score for that requirement. These individual item scores will be added to produce a rating for each medium.

C. Determine whether additional characteristics are important to your course. If so, place additional items at the end of the list (page 4) and rate their importance in the "Importance" column. 


\section{STEP 2: Determine each medium's ability to meet each requirement.}

A. Note the rating given to each medium's ability to meet the instructional design characteristics. Each medium has been given a score on a scale of " 0 " (cannot meet the characteristic) to "3" (meets the characteristic effectively). These scores are listed in the top half of the rows for each medium noted across the top of the page.

B. Multiply the importance factor you assigned for each characteristic by the score of each medium's ability to meet that characteristic. For example, if you assigned a "9" to the first characteristic, multiply 9 times " 0 " for print. The answer " 0 " should be entered in the block under "print," which corresponds to Item 1.

For Example:

\begin{tabular}{|c|c|c|c|c|c|}
\hline $\begin{array}{l}\text { INSTRUCTIONAL DESIGN } \\
\text { CHARACTERISTICS } \\
\text { How important is it that the medium selected be able } \\
\text { to: }\end{array}$ & 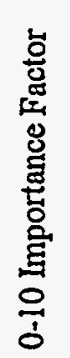 & 茊 & 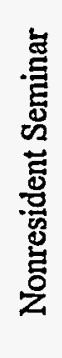 & 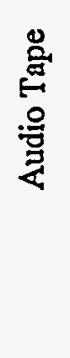 & 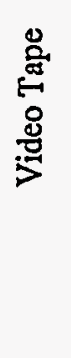 \\
\hline $\begin{array}{l}\text { 1. Provide real-time interaction between } \\
\text { students and instructor }\end{array}$ & & 0 & 1 & 0 & 0 \\
\hline
\end{tabular}

C. For each characteristic, multiply the importance factor by the assigned score for each medium. Write each product in the bottom half of each box.

\section{STEP 3: Calculate the totals for each medium.}

A. The sum of each column (all the products just calculated) indicates each medium's overall appropriateness for your course. Add the products in each column to produce subtotals for each page.

B. Complete the subtotal section on the last page and computer the grand totals.

\section{STEP 4: Identify potential distance learning media.}

The media receiving the highest scores are potential tools for exporting your course. Review the data, taking a hard look at those characteristics that you rated a 9 or 10 in the "Importance Factor" column. Consider only those media with the highest scores that are capable of satisfying your critical requirements. Remember, this is not a final decision for DL or for a particular medium. Rather, this guide will serve as a basis for further study. NONRESIDENT In some cases, a mix of media may be appropriate. 
Definitions of media are in Section II, Overview of Distance Learning Media (Introduction)

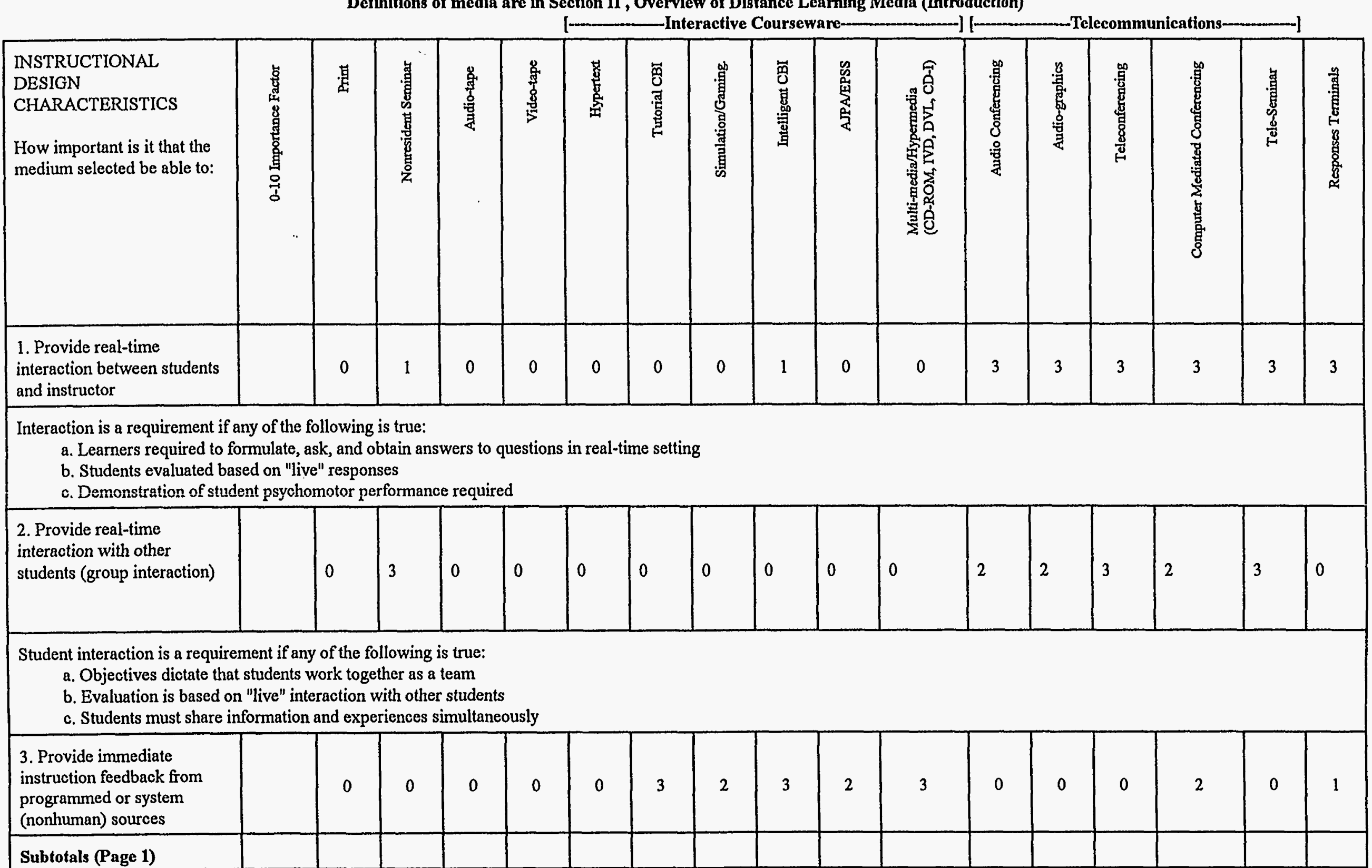




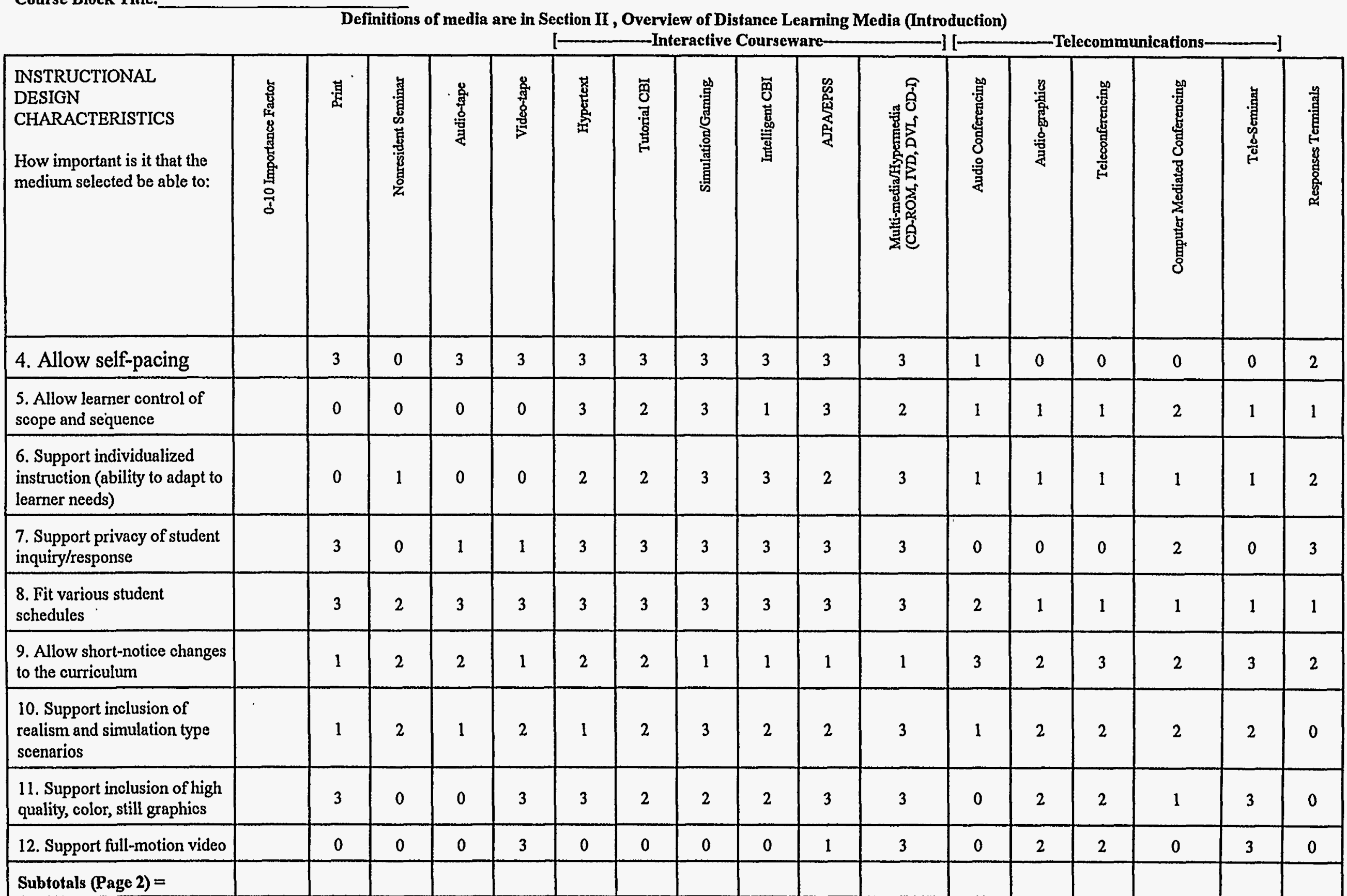




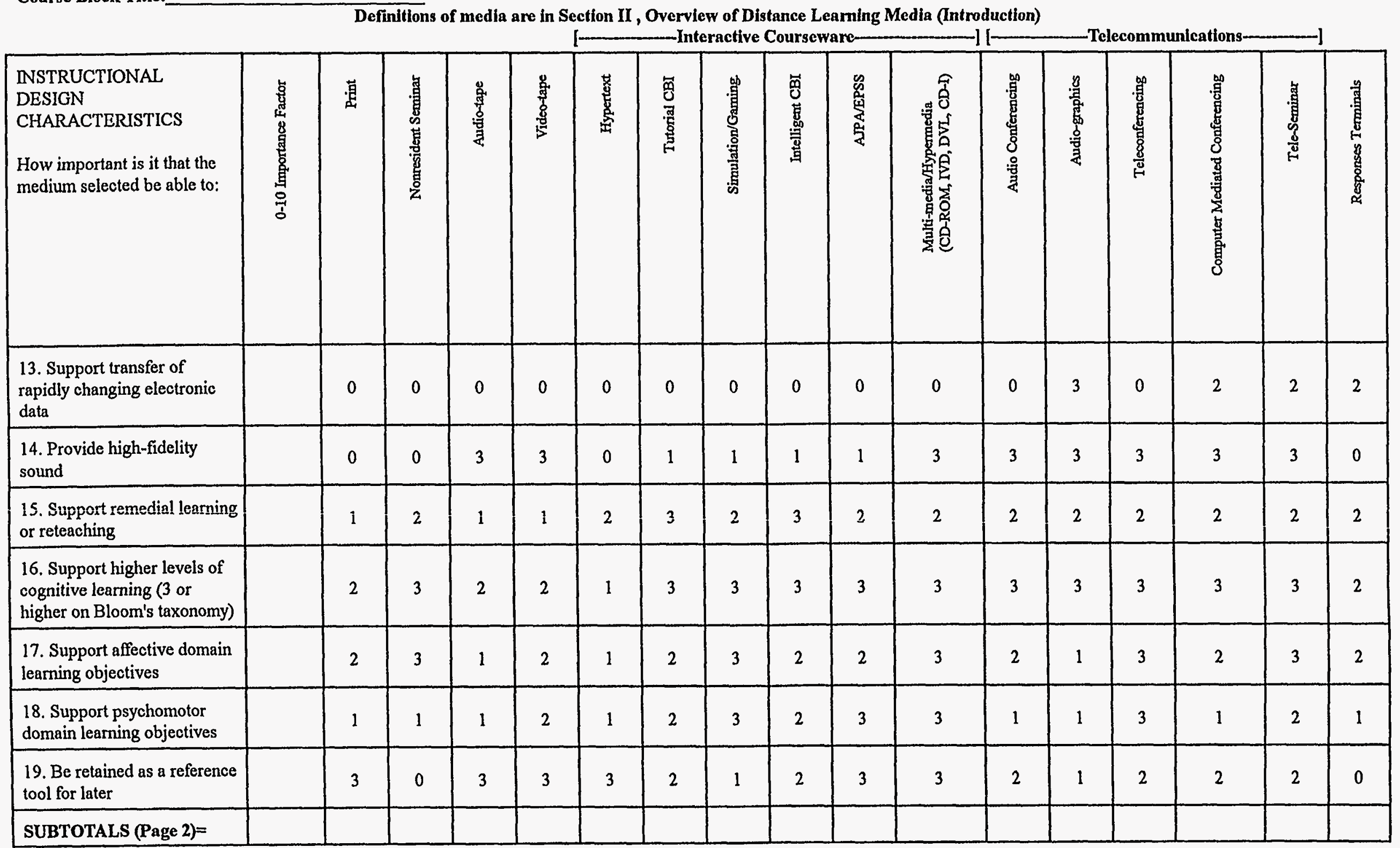




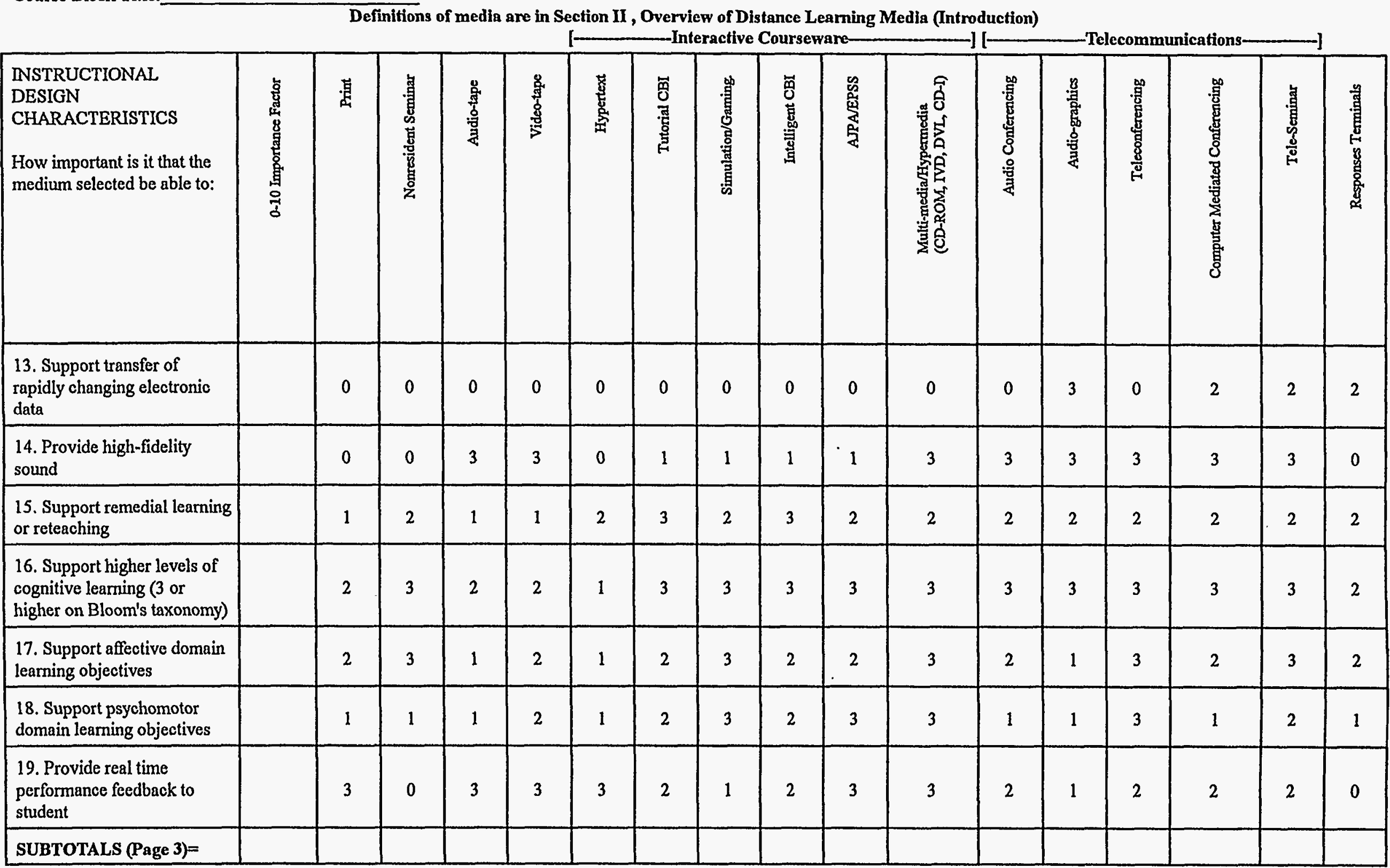




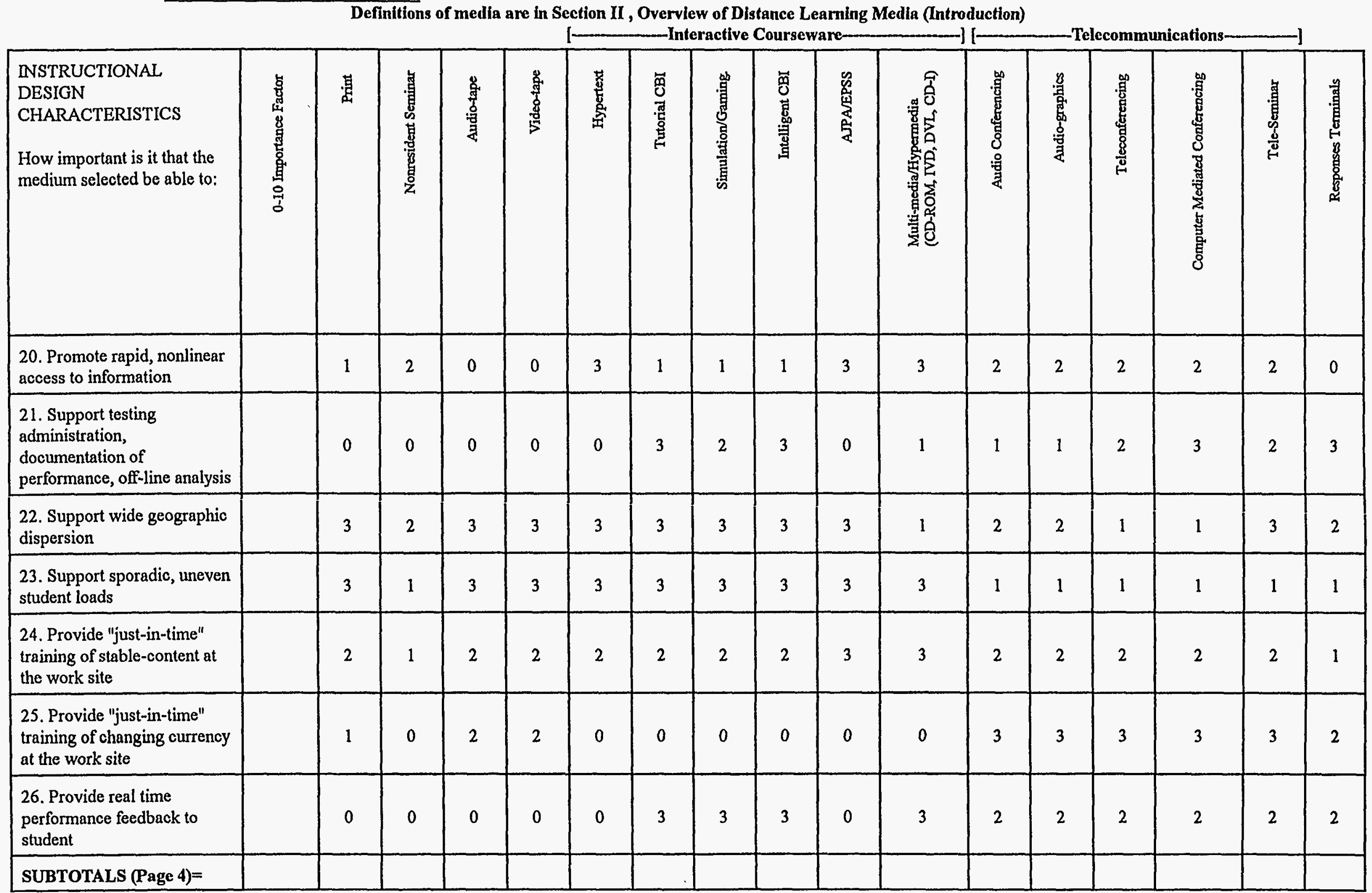


Definitions of media are in Section $\mathrm{II}$, Overview of Distance Learning Media (Introduction)

\begin{tabular}{|c|c|c|c|c|c|c|c|c|c|c|c|c|c|c|c|c|c|}
\hline $\begin{array}{l}\text { INSTRUCTIONAL } \\
\text { DESIGN } \\
\text { CHARACTERISTICS } \\
\text { How important is it that the } \\
\text { medium selected be able to: }\end{array}$ & 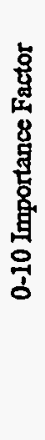 & 藏 & 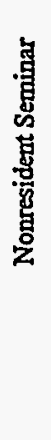 & $\begin{array}{l}\text { : } \\
\text { 总 } \\
\text { : }\end{array}$ & $\begin{array}{l}\text { 总 } \\
\text { 总 } \\
\text { 总 }\end{array}$ & $\begin{array}{l}\text { 苞 } \\
\text { 总 }\end{array}$ & 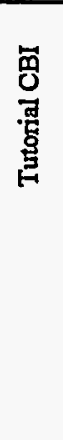 & 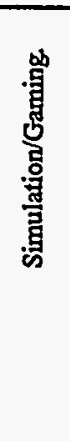 & $\begin{array}{l}\text { 惫 } \\
\text { 莒 } \\
\text { 总 } \\
\text { 总 }\end{array}$ & 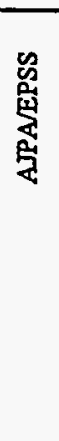 & 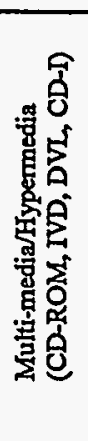 & 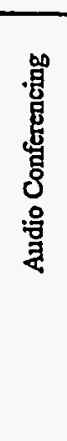 & 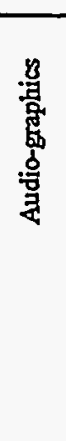 & 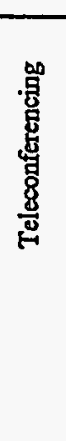 & 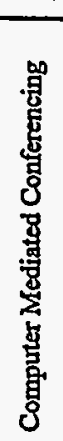 & 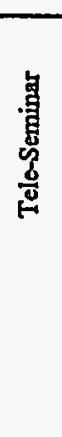 & 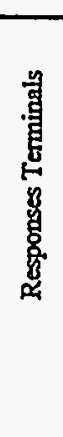 \\
\hline Subtotals (Page 1) $=$ & & & & & & & & & & & & & & & & & \\
\hline Subtotals (Page 2)= & & & & & & & & & & & & & & & & & \\
\hline Subtotals (Page 3)= & & & & & & & & & & & & & & & & & \\
\hline Subtotals $($ Page 4$)=$ & & & & & & & & & & & & & & & & & \\
\hline GRAND TOTALS & & & & & & & & & & & & & & & & & \\
\hline
\end{tabular}




\section{NONRESIDENT PROGRAMS SURVEY}

This survey is for those Air University schools with nonresident programs. It is intended to provide preliminary data for a series of future meetings to explore ways to enhance Air University's present nonresident programs through the expansion of available technologies.

INSTRUCTIONS: The course director or individual most knowledgeable about the nonresident program(s) offered by your school should complete this survey. Please complete a separate form for each nonresident program. If you have both correspondence and seminar programs, a separate survey is needed for each. For those questions requiring a lengthy explanation, type your response on a separate page and attach to this survey.

NONRESIDENT PROGRAMS SURVEY

Page 1 of 2

INSTITUTION NAME:

PROGRAM

Name/Duty Title/Phone Number of person completing this survey:

Name/Phone Number of $P O C$ for future meetings:

1. What type of distance learning does this program currently utilize?

2. How much time is allowed to complete this program?

3. How often is this program offered each academic year?

4. How many students are usually enrolled each academic year?

5. If applicable, what are the minimum and maximum class sizes accepted?

6. What is the location of your students? (Check all that apply) dispersed worldwide CONUS only AF bases only Military Bases Other (Identify:

7. What percentage of students are:

Reserve Civilian Active Duty AF International Army Navy Marines International Class sizes accepted? 
8. Do you foresee any changes that may impact the demand for your program in the future? (Explain)

9. How many personnel within your orgranization (full-time equivalents) are supporting this program?

10. What other organizations support this program?

11. Is there a resident version of this program? If yes, do the objectives of the resident program differ from those of this nonresident program?

12. If the answer to 11 was yes, has your school formally considered changing or expanding this nonresident program to make it more closely resemble the resident course?

If yes, how? (Explain)

If no, why not? (Explain)

13. If Air University has access to various telecommunications media enabling direct and live communication between students and instructors/guest lecturers, how might you use this technology to enhance this nonresident program? (Explain)

14. Are you currently using interactive courseware, computer-based, or multimedia technology to enhance this program? If yes, please list by type:

15. Do you foresee using interactive courseware, computer-based, or multimedia technology to enhance this program?

If yes, how? (Explain)

If no, why not? (Explain)

16. How might you alter existing nonresident programs' objectives to make use of these technologies if available in the future? (Explain)

17. What percentage of your program could benefit from computer enhancements? In what ways?

18. What percentage of your program could benefit from telecommunications enhancements? In what ways?

19. Do you have personnel in your organization trained to build computer-based or multimedia courseware? How many?

20. What have been the major factors hindering the application of technology in this course? (On a separate page, list in order of most significant to least significant)

21. What other general problems do you face in the development, production, distribution, and administration of this program?

22. Please feel free to add other thoughts you may have concerning distance learning at Air University on a separate page. 


\section{APPENDIX B}

\section{SURVEY DATA MATRIX}

B-1 
- 


\begin{tabular}{|c|c|c|c|c|c|}
\hline 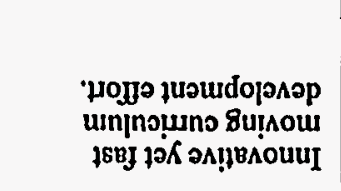 & 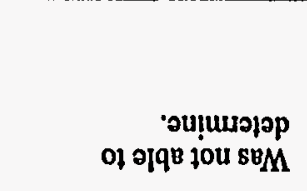 & 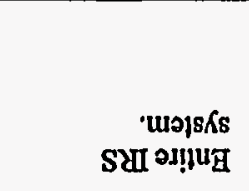 & 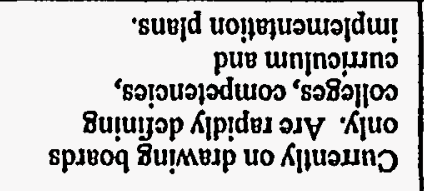 & 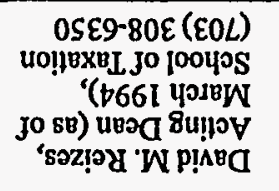 & 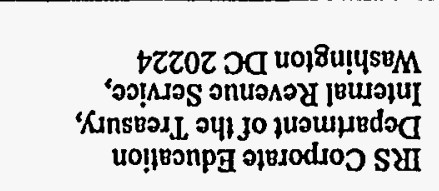 \\
\hline & 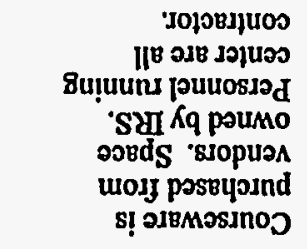 & 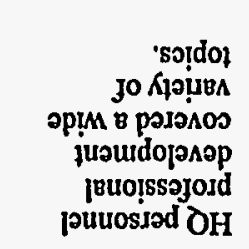 & 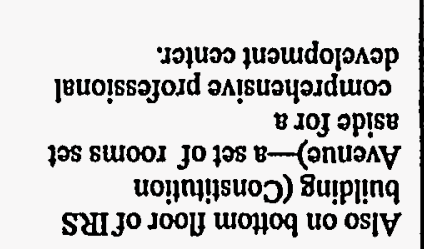 & 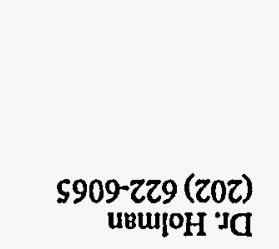 & 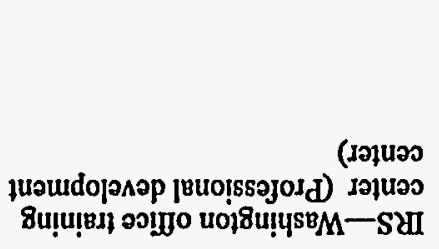 \\
\hline 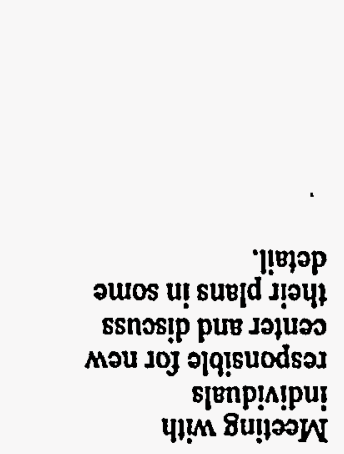 & 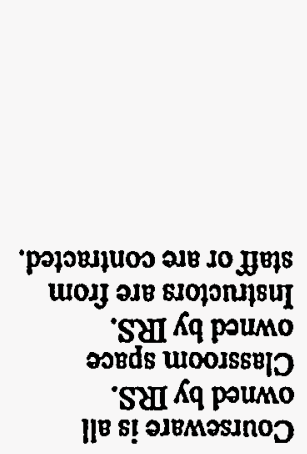 & 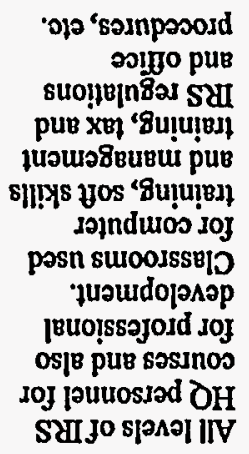 & 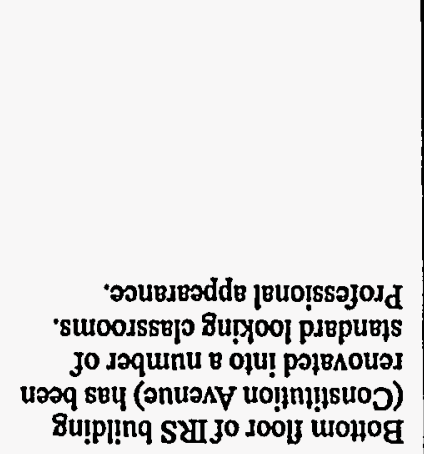 & 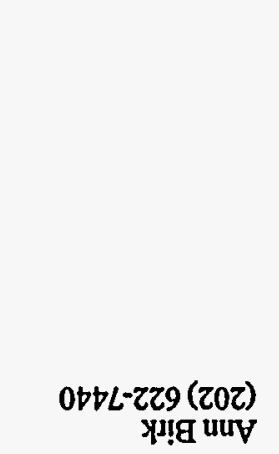 & 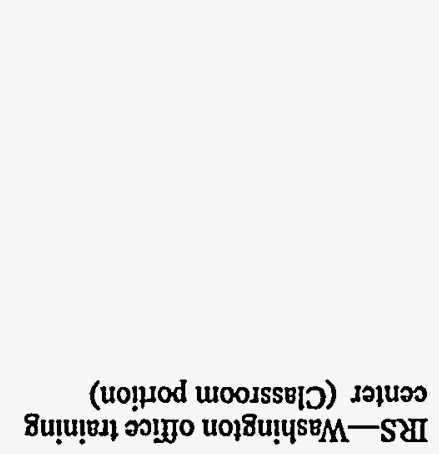 \\
\hline & & 4 & 117migr 109 & & 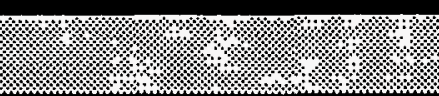 \\
\hline sa10N IB!̣วadS & d!ys.zวuм0 & 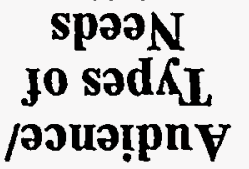 & 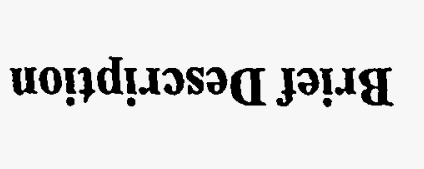 & $\begin{array}{l}\text { 108一u0D } \\
\text { Jo qu!Od }\end{array}$ & 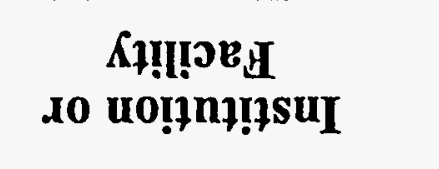 \\
\hline
\end{tabular}




\begin{tabular}{|c|c|c|c|c|c|}
\hline $\begin{array}{c}\text { Institution or } \\
\text { Facility }\end{array}$ & $\begin{array}{l}\text { Point of } \\
\text { Contact }\end{array}$ & Brief Description & $\begin{array}{c}\text { Audience/ } \\
\text { Types of } \\
\text { Needs }\end{array}$ & Ownership & Special Notes \\
\hline $\begin{array}{l}\text { USDA Graduate School } \\
\text { Rm } 1025 \text { South Agriculture } \\
\text { Building, } \\
14 \text { th St. and Independence Ave., } \\
\text { S.W. } \\
\text { Washington DC. } 20250 \\
\text { USDA Video and Teleconference } \\
\text { Division and USDA } \\
\text { Teleconference Center, } \\
\text { Rm } 1618 \text {-South Bldg, Washington } \\
\text { DC 20250-1300, }\end{array}$ & $\begin{array}{l}\text { Philip H. Hudson, } \\
\text { Director } \\
\text { (202) 720-2077 } \\
\text { Larry A. Quinn, } \\
\text { Chief, } \\
\text { (202) 720-6072 }\end{array}$ & $\begin{array}{l}\text { Institution of higher learning } \\
\text { under the umbrella of the } \\
\text { Department of Agriculture but } \\
\text { entirely cost-reimbursable. } \\
\text { Vast number of courses } \\
\text { offered in DC. Contract } \\
\text { services elsewhere. Most } \\
\text { courses are accredited. }\end{array}$ & $\begin{array}{l}\text { All agencies of } \\
\text { the } \\
\text { government. } \\
\text { Generic training } \\
\text { and } \\
\text { development } \\
\text { and a wide } \\
\text { range of } \\
\text { continuing } \\
\text { education areas. }\end{array}$ & $\begin{array}{l}\text { Courses are } \\
\text { developed by } \\
\text { contractors but owned } \\
\text { by school. Almost all } \\
\text { instructors are } \\
\text { contractors. Almost } \\
\text { all facilities are } \\
\text { contracted. }\end{array}$ & $\begin{array}{l}\text { Has a board that } \\
\text { functions much as a } \\
\text { college board of } \\
\text { regents would } \\
\text { function. }\end{array}$ \\
\hline $\begin{array}{l}\text { OPM Washington DC Regional } \\
\text { Training Center }\end{array}$ & $\begin{array}{l}\text { A. Edward Franklin, } \\
\text { Division Manager, } \\
\text { Administrative } \\
\text { Careers Training } \\
\text { Division, 1400 } \\
\text { Wilson Boulcvard, } \\
\text { Suite 300, Rosslyn, } \\
\text { VA 22210 } \\
\text { (703) 312-7210. } \\
\text { Also Jenise S. Rowe } \\
\text { at same location and } \\
\text { phone. }\end{array}$ & $\begin{array}{l}\text { Housed in a recently } \\
\text { refurbished } 12 \text { story office } \\
\text { building in Rosslyn. Lange } \\
\text { number of classrooms. One } \\
\text { of several regional training } \\
\text { centers, country-wide. }\end{array}$ & $\begin{array}{l}\text { Provides } \\
\text { interagency } \\
\text { training in } \\
\text { broad range of } \\
\text { areas and for all } \\
\text { GS levels. } \\
\text { (Other OPM } \\
\text { centers are } \\
\text { specifically } \\
\text { positioned for } \\
\text { advanced and } \\
\text { SES-level } \\
\text { training) }\end{array}$ & $\begin{array}{l}\text { Contracts the } \\
\text { development but all } \\
\text { courseware is owned } \\
\text { by OPM. Contracts } \\
\text { most of the } \\
\text { instructors. Facility is } \\
\text { leased. }\end{array}$ & $\begin{array}{l}\text { SES and Seminar } \\
\text { facilities should be } \\
\text { visited. }\end{array}$ \\
\hline
\end{tabular}




\begin{tabular}{|c|c|c|c|c|c|}
\hline $\begin{array}{l}\text { Institution or } \\
\text { Facility }\end{array}$ & $\begin{array}{l}\text { Point of } \\
\text { Contact }\end{array}$ & Brief Description & $\begin{array}{l}\text { Audience/ } \\
\text { Types of } \\
\text { Needs }\end{array}$ & Ownership & Special Notes \\
\hline $\begin{array}{l}\text { United States State Department } \\
\text { National Foreign Affairs Training } \\
\text { Center }\end{array}$ & $\begin{array}{l}\text { Alice Murry } \\
\text { (703) 302-6729 }\end{array}$ & $\begin{array}{l}\text { Recently completed a } \\
\text { beautiful, large custom-built, } \\
\text { campus. Many sizes and } \\
\text { types of classsooms and } \\
\text { training facilities. Do not } \\
\text { provide residency or } \\
\text { accreditation. Looks and feels } \\
\text { like a very nice small college } \\
\text { campus (minus dorms and } \\
\text { student union). }\end{array}$ & $\begin{array}{l}\text { Almost entirely } \\
\text { foreign service } \\
\text { and civil service } \\
\text { State } \\
\text { Department } \\
\text { employees. } \\
\text { Heavy but not } \\
\text { exclusive } \\
\text { emphasis on } \\
\text { language } \\
\text { training. } \\
\text { Consulate } \\
\text { training and a } \\
\text { senior executive } \\
\text { course are } \\
\text { among other } \\
\text { courses. }\end{array}$ & $\begin{array}{l}\text { Facility and all } \\
\text { equipment is owned } \\
\text { by school. A large } \\
\text { percentage of } \\
\text { instructors are } \\
\text { contracted. }\end{array}$ & $\begin{array}{l}\text { Very active } \\
\text { multimedia efforts. } \\
\text { Exploring distance } \\
\text { learning. }\end{array}$ \\
\hline GSA Interagency Training & $\begin{array}{l}\text { Ron Kobus } \\
(703) 603-3213\end{array}$ & $\begin{array}{l}\text { Leased rooms ( } 10 \text { classrooms, } \\
1 \text { office suite) in a plush } \\
\text { Crystal City Office building. } \\
\text { Easy access. }\end{array}$ & $\begin{array}{l}\text { Generic } \\
\text { computer } \\
\text { training, TQM, } \\
\text { team-building, } \\
\text { and GSA- } \\
\text { related courses, } \\
\text { All branches of } \\
\text { government. }\end{array}$ & $\begin{array}{l}\text { Courses are } \\
\text { developed by } \\
\text { contractors but owned } \\
\text { by GSA. All space } \\
\text { and instructors are } \\
\text { contracted. }\end{array}$ & $\begin{array}{l}\text { GSA schedules } \\
\text { extensive training } \\
\text { across the country. } \\
\text { Cost appears relatively } \\
\text { low. }\end{array}$ \\
\hline $\begin{array}{l}\text { General Accounting Office, } \\
\text { Washington, DC } 20548\end{array}$ & $\begin{array}{l}\text { H. Rosalind Cowie, } \\
\text { Special Assistant, } \\
\text { Training, Policy and } \\
\text { Liaison, GAO } \\
\text { Training Institute, } \\
\text { (202) S12-7790 }\end{array}$ & $\begin{array}{l}\text { Remodeled portion of the } \\
\text { GAO HQ building (about } 10 \\
\text { years ago). Includes several } \\
\text { classrooms and a learning } \\
\text { center. Professional look and } \\
\text { feel. }\end{array}$ & $\begin{array}{l}\text { Almost entirely } \\
\text { for internal } \\
\text { training needs. } \\
\text { Wide range of } \\
\text { training from } \\
\text { computer } \\
\text { training, soft } \\
\text { skills and } \\
\text { management, to } \\
\text { evaluation and } \\
\text { audit-related } \\
\text { courses. }\end{array}$ & $\begin{array}{l}\text { All space, instructors, } \\
\text { and courseware is } \\
\text { owned by GAO. }\end{array}$ & $\begin{array}{l}\text { Experimenting with } \\
\text { land-based video- } \\
\text { conferencing } \\
\text { options-utilizing } \\
\text { their existing } \\
\text { equipment. }\end{array}$ \\
\hline
\end{tabular}




\begin{tabular}{|c|c|c|c|c|c|}
\hline $\begin{array}{c}\text { Institution or } \\
\text { Facility }\end{array}$ & $\begin{array}{l}\text { Point of } \\
\text { Contact }\end{array}$ & Brief Description & $\begin{array}{l}\text { Audience/ } \\
\text { Types of } \\
\text { Needs }\end{array}$ & Ownership & Special Notes \\
\hline $\begin{array}{l}\text { United States Nuclear Regulatory } \\
\text { Commission } \\
\text { Technical Training Center, } \\
\text { Obsorne Office Center, Suite 200, } \\
\text { 5700 Brainerd Road, Chattanooga, } \\
\text { TN } 37411-4017\end{array}$ & $\begin{array}{l}\text { Steven A. Arndt, } \\
\text { Assistant Director } \\
\text { (615) 855-6641 also } \\
\text { Leonard Reidinger }\end{array}$ & $\begin{array}{l}\text { Will soon occupy four stories } \\
\text { of a beautiful office building } \\
\text { in Chattanooga, TN. Houses } \\
\text { staff, classrooms, and a half- } \\
\text { dozen full-scope simulators. }\end{array}$ & $\begin{array}{l}\text { NRC HQ staff, } \\
\text { regional staff } \\
\text { and plant } \\
\text { inspectors. } \\
\text { Systems } \\
\text { courses, } \\
\text { hands-on } \\
\text { simulator } \\
\text { training and } \\
\text { mann other } \\
\text { technical } \\
\text { engineering } \\
\text { related areas } \\
\text { (e.g., PRA). }\end{array}$ & $\begin{array}{l}\text { All equipment and } \\
\text { courses are owned by } \\
\text { the NRC. Some } \\
\text { courses are contracted } \\
\text { for development and } \\
\text { teaching. Facility is } \\
\text { leased. Some support } \\
\text { services are leased. }\end{array}$ & $\begin{array}{l}\text { Currently starting a } \\
\text { classroom } \\
\text { modernization project. }\end{array}$ \\
\hline $\begin{array}{l}\text { NRC White Flint II Training } \\
\text { Center }\end{array}$ & $\begin{array}{l}\text { Carolyn Bassin } \\
\text { (301) 492-8526, } \\
\text { USNRC, Rockville } \\
\text { Maryland }\end{array}$ & $\begin{array}{l}\text { Recently completed center in } \\
\text { a brand-new building. Three } \\
\text { computer training classrooms. } \\
\text { Four regular classrooms with } \\
\text { large video monitors and } \\
\text { movable teleconferencing } \\
\text { setup. Innovative information } \\
\text { access concepts for students. } \\
\text { Also a multimedia learning } \\
\text { center. }\end{array}$ & $\begin{array}{l}\text { NRC staff at all } \\
\text { levels. All } \\
\text { except technical } \\
\text { training } \\
\text { provided by } \\
\text { center in } \\
\text { Chattanooga. }\end{array}$ & $\begin{array}{l}\text { Much of the training } \\
\text { is contracted out. }\end{array}$ & $\begin{array}{l}\text { Have gone to 32" } \\
\text { monitors rather than } \\
\text { video projection. } \\
\text { Interesting } \\
\text { information services } \\
\text { via LAN and speciai } \\
\text { computers. }\end{array}$ \\
\hline $\begin{array}{l}\text { FBI Academy, } \\
\text { Quantico,VA 22135 }\end{array}$ & $\begin{array}{l}\text { Charles G. } \\
\text { Bollmann, Chief, } \\
\text { Instructional } \\
\text { Technology Services } \\
\text { (703) 640-1124 also } \\
\text { Les Davis (703) } \\
\text { 640-1145 }\end{array}$ & $\begin{array}{l}\text { Ten to twenty-year-old } \\
\text { residence campus facility in } \\
\text { Quantico, Va. Houses around } \\
\text { a } 1000 \text { students at a time. }\end{array}$ & $\begin{array}{l}\text { FBI, DEA, ATF } \\
\text { agent training } \\
\text { and many other } \\
\text { law- } \\
\text { enforcement } \\
\text { courses. }\end{array}$ & $\begin{array}{l}\text { Contract out food } \\
\text { services. All } \\
\text { instructors are } \\
\text { brought in as long- } \\
\text { term or short-term } \\
\text { faculty. }\end{array}$ & \\
\hline
\end{tabular}




\begin{tabular}{|c|c|c|c|c|c|}
\hline $\begin{array}{l}\text { Institution or } \\
\text { Facility }\end{array}$ & $\begin{array}{l}\text { Point of } \\
\text { Contact }\end{array}$ & Brief Description & $\begin{array}{l}\text { Audience/ } \\
\text { Types of } \\
\text { Needs }\end{array}$ & Ownership & Special Notes \\
\hline $\begin{array}{l}\text { Federal Aviation Administration } \\
\text { Regulations \& Standards, } \\
\text { Training Program Division (AHT- } \\
\text { 200), } \\
\text { NASSIF Bldg., } \\
\text { NW Plaza (PL-100), } 400 \text { Seventh } \\
\text { Street, SW, Washington, DC } \\
\text { 20590-0001 }\end{array}$ & $\begin{array}{l}\text { Larry A. Blevins, } \\
\text { Manager, } \\
\text { (202) } 366-7200\end{array}$ & $\begin{array}{l}\text { Have completed extensive } \\
\text { mission analysis, market } \\
\text { survey, cost-effectiveness } \\
\text { analysis for use of } 1 \text {-way } \\
\text { video and 2-way audio for } \\
\text { higher education and training. }\end{array}$ & $\begin{array}{l}\text { FAA personnel } \\
\text { around the } \\
\text { country, } \\
\text { reducing the } \\
\text { number of } \\
\text { courses offered } \\
\text { only at regional } \\
\text { training centers. }\end{array}$ & $\begin{array}{l}\text { Contractor support for } \\
\text { conversion of courses } \\
\text { for distance delivery. } \\
\text { Satellite and audio } \\
\text { hardware will be } \\
\text { owned by } \\
\text { administration. }\end{array}$ & $\begin{array}{l}\text { Excellent ground } \\
\text { work laid-are very } \\
\text { willing to share and } \\
\text { help others facing } \\
\text { similar challenges. }\end{array}$ \\
\hline $\begin{array}{l}\text { United States Postal Service } \\
\text { Training Center } \\
\text { Norman, OK }\end{array}$ & $\begin{array}{l}\text { Richard Manor } \\
\text { (405) 366-4610 }\end{array}$ & $\begin{array}{l}\text { Large training center in } \\
\text { Norman, OK. }\end{array}$ & $\begin{array}{l}\text { Variety of } \\
\text { training. } \\
\text { Specialized } \\
\text { hardware } \\
\text { maintenance } \\
\text { was specifically } \\
\text { described. }\end{array}$ & $\begin{array}{l}\text { Conducted much of } \\
\text { the training on actual } \\
\text { equipment, with } \\
\text { amazingly little } \\
\text { impact to overall } \\
\text { resource availability. }\end{array}$ & \\
\hline $\begin{array}{l}\text { DOE Central Training Academy, } \\
\text { P.O. Box } 5400 \text {, } \\
\text { Albuquerque, NM } 87115\end{array}$ & $\begin{array}{l}\text { Don Cook, Director } \\
\text { or Robbie Smith, } \\
\text { Senior Training } \\
\text { Programs Specialist, } \\
\text { (505) } 845.4804\end{array}$ & $\begin{array}{l}\text { Making extensive use of } \\
\text { multimedia, CBT and } \\
\text { distance learning (in near } \\
\text { future). }\end{array}$ & $\begin{array}{l}\text { Security } \\
\text { training through } \\
\text { DOE. }\end{array}$ & $\begin{array}{l}\text { Leasing distance } \\
\text { learning support from } \\
\text { HP. }\end{array}$ & $\begin{array}{l}\text { Will be running first } \\
\text { distance learning } \\
\text { courses in the near } \\
\text { future. }\end{array}$ \\
\hline $\begin{array}{l}\text { Hanford Site } \\
\text { P.O. Box } 1970 \\
\text { Richland, WA } 99352\end{array}$ & $\begin{array}{l}\text { Leopold Smigelski } \\
\text { Manager, Instructor } \\
\text { Training and } \\
\text { Training Evaluations } \\
\text { (509) } 372-3210 \\
\text { Steve Haliday } \\
\text { (WHC) Advanced } \\
\text { Training Technology } \\
\text { Group }\end{array}$ & $\begin{array}{l}\text { Three multimedia learning } \\
\text { centers of } 25 \text { learning stations } \\
\text { each service } 15,000 \\
\text { employees. One center is } \\
\text { located in community college } \\
\text { and used by college during } \\
\text { evening hours. High } \\
\text { acceptance, cost savings, and } \\
\text { utilization rates due to careful } \\
\text { scheduling. Extensive } \\
\text { management support. }\end{array}$ & $\begin{array}{l}\text { All employees } \\
\text { of } \\
\text { Westinghouse } \\
\text { Hanford } \\
\text { Company, their } \\
\text { DOE } \\
\text { customers, and } \\
\text { site visitors. } \\
\text { General } \\
\text { employee } \\
\text { training, various } \\
\text { other mandated } \\
\text { training. }\end{array}$ & $\begin{array}{l}\text { Staff of full-time } \\
\text { employees developed } \\
\text { courseware and outtit, } \\
\text { schedules, runs and } \\
\text { maintains centers. } \\
\text { Has been actively } \\
\text { seeking other DOE } \\
\text { sites interested in } \\
\text { receiving free copies } \\
\text { of courseware. }\end{array}$ & $\begin{array}{l}\text { Seeking to make a } \\
\text { generic version of } \\
\text { general employee } \\
\text { training for broader } \\
\text { application across } \\
\text { DOE. }\end{array}$ \\
\hline
\end{tabular}




\begin{tabular}{|c|c|c|c|c|c|}
\hline $\begin{array}{l}\text { Institution or } \\
\text { Facility }\end{array}$ & $\begin{array}{l}\text { Point of } \\
\text { Contact }\end{array}$ & Brief Description & $\begin{array}{l}\text { Audience/ } \\
\text { Types of } \\
\text { Needs }\end{array}$ & Ownership & Special Notes \\
\hline $\begin{array}{l}\text { Savannah Rivers Site, } \\
\text { Training Integration Division, } \\
\text { Westinghouse Savannah River } \\
\text { Company, Building } 991-\text { W Aiken } \\
\text { Commercial Center } 139 \\
\text { Darlington Drive, } \\
\text { Aiken, SC } 29803\end{array}$ & $\begin{array}{l}\text { James Glassman, } \\
\text { Computer-Based } \\
\text { Training Manager, } \\
\text { (803) 644-4912 }\end{array}$ & $\begin{array}{l}\text { Eight multimedia learning } \\
\text { centers consisting of } 15-20 \\
\text { learning stations each. } \\
\text { Service separate departments. } \\
\text { Provides skill training, } \\
\text { primarily. Some utilization } \\
\text { problems. }\end{array}$ & $\begin{array}{l}\text { Utilizes some } \\
\text { internally } \\
\text { developed } \\
\text { courseware and } \\
\text { several } \\
\text { commercially } \\
\text { acquired/develo } \\
\text { ped courses for } \\
\text { skill training } \\
\text { and some } \\
\text { mandated } \\
\text { training. }\end{array}$ & $\begin{array}{l}\text { Government owned } \\
\text { hardware. Support } \\
\text { staff are contractor } \\
\text { employees. Some } \\
\text { internal development. } \\
\text { Contracting } \\
\text { development with } \\
\text { major IVD supplier. }\end{array}$ & \\
\hline $\begin{array}{l}\text { Idaho National Engineering } \\
\text { Laboratory, P.O. Box } 1625 \text {, } \\
\text { Idaho Falls, ID } 83415\end{array}$ & $\begin{array}{l}\text { Loren Peterson } \\
\text { (new), Coleman } \\
\text { Technologies, } \\
\text { Director of Central } \\
\text { Training, PO Box } \\
\text { 1625, Idaho Falls, ID } \\
\text { 83415 } \\
\text { (208) } 526-4179\end{array}$ & $\begin{array}{l}\text { Traditional classrooms. Just } \\
\text { establishing a small } \\
\text { multimedia center. Will } \\
\text { expand number of centers in } \\
\text { near future. }\end{array}$ & $\begin{array}{l}\text { All employees, } \\
\text { mandatory } \\
\text { training. } \\
\text { Looking at } \\
\text { management } \\
\text { and other types } \\
\text { of training. }\end{array}$ & $\begin{array}{l}\text { Department of Energy } \\
\text { developed and } \\
\text { commercially } \\
\text { developed materials. } \\
\text { Facility-owned } \\
\text { hardware. }\end{array}$ & $\begin{array}{l}\text { Of late very keen } \\
\text { management support. }\end{array}$ \\
\hline $\begin{array}{l}\text { Air Force Academy } \\
\text { HQ USAFA/DFE } \\
2354 \text { Fairchild Dr. Suite } 4 \mathrm{~K} 25 \\
\text { USAF Academy, CO } 80840-6200\end{array}$ & $\begin{array}{l}\text { Mary Marlino, Ed.D, } \\
\text { Director } \\
\text { Educational } \\
\text { Technology } \\
\text { (719) } 472-2549\end{array}$ & $\begin{array}{l}\text { Academy has several } \\
\text { multimedia learning centers } \\
\text { distributed throughout the } \\
\text { academy. Used to deliver } \\
\text { language and history courses. }\end{array}$ & Cadets. & $\begin{array}{l}\text { All resources owned } \\
\text { by the Air Force. } \\
\text { Cadets are issued their } \\
\text { individual computers. }\end{array}$ & $\begin{array}{l}\text { Very advanced. All } \\
\text { cadets have own } \\
\text { computers and a } \\
\text { computer in every } \\
\text { classroom. }\end{array}$ \\
\hline Air Force Institute of Technology & $\begin{array}{l}\text { Capt William } \\
\text { Cramer, Chief, } \\
\text { Media Management } \\
\text { Div. } \\
\text { wcramer@afit.af.mil } \\
(513) 255-6863\end{array}$ & $\begin{array}{l}\text { Teaching a number of courses } \\
\text { via a large satellite network. } \\
\text { 1-way video, 2-way audio. }\end{array}$ & $\begin{array}{l}\text { Airmen, } \\
\text { technical } \\
\text { training. }\end{array}$ & $\begin{array}{l}\text { Air Force owned } \\
\text { equipment. }\end{array}$ & \\
\hline
\end{tabular}




\begin{tabular}{|c|c|c|c|c|c|}
\hline $\begin{array}{c}\text { Institution or } \\
\text { Facility }\end{array}$ & $\begin{array}{l}\text { Point of } \\
\text { Contact }\end{array}$ & Brief Description & $\begin{array}{l}\text { Audience/ } \\
\text { Types of } \\
\text { Needs }\end{array}$ & Ownership & Special Notes \\
\hline Air University & $\begin{array}{l}\text { Adelaide Cherry, } \\
\text { Chief, Educational } \\
\text { Technology } \\
\text { (205) 953-3003 or } \\
\text { LTC Ralph Cabaniss } \\
\text { (Air Command \& } \\
\text { Staff College) }\end{array}$ & $\begin{array}{l}\text { Recently was traditional } \\
\text { school house education and } \\
\text { training. Making rapid strides } \\
\text { in adopting distance education } \\
\text { and multimedia options. }\end{array}$ & $\begin{array}{l}\text { Broad range of } \\
\text { courses. } \\
\text { Further } \\
\text { research } \\
\text { needed. }\end{array}$ & $\begin{array}{l}\text { Air Forced owned } \\
\text { facilities. }\end{array}$ & $\begin{array}{l}\text { Looking seriously at } \\
\text { distance learning } \\
\text { options. }\end{array}$ \\
\hline Air Force Air Combat Command & & $\begin{array}{l}\text { Supported work on innovative } \\
\text { multimedia training of } \\
\text { troubleshooting for aircraft } \\
\text { maintenance. }\end{array}$ & $\begin{array}{l}\text { Troubleshootin } \\
\text { g technicians. }\end{array}$ & $\begin{array}{l}\text { Further research } \\
\text { needed. }\end{array}$ & \\
\hline $\begin{array}{l}\text { Brooks, Randolph Air Force Bases, } \\
\text { San Antonio, TX. }\end{array}$ & $\begin{array}{l}\text { Pat Bowden } \\
\text { Air Education \& } \\
\text { Training Command } \\
\text { (210) 652-6449 }\end{array}$ & $\begin{array}{l}\text { Brooks and Randolph AFB } \\
\text { conduct research and } \\
\text { feasibility studies on new } \\
\text { training technologies for } \\
\text { incorporation in the Air Force } \\
\text { training commands. }\end{array}$ & $\begin{array}{l}\text { Broad range of } \\
\text { courses. }\end{array}$ & Air Force owned. & \\
\hline $\begin{array}{l}\text { Army Research Institute, Orlando, } \\
\text { FL. }\end{array}$ & $\begin{array}{l}\text { Steven Goldman, } \\
\text { STRICOM, Orlando } \\
\text { Ficld Unit, 12350 } \\
\text { Research Parkway, } \\
\text { Orlando, FL 23826- } \\
3276 \\
\text { (407) 380-4378 }\end{array}$ & $\begin{array}{l}\text { Studying potential of virtual } \\
\text { reality for Army training. }\end{array}$ & $\begin{array}{l}\text { Application of } \\
\text { advanced } \\
\text { technology for } \\
\text { various kinds of } \\
\text { simulation and } \\
\text { training. }\end{array}$ & Air Force owned. & \\
\hline $\begin{array}{l}\text { Army Research Institute, } \\
\text { Boise, } \mathbb{D}\end{array}$ & $\begin{array}{l}\text { Ruth Phelps, } 1910 \\
\text { University Dr, Boise, } \\
\text { ID 83725-1140, } \\
\text { (208) 334-9390 }\end{array}$ & $\begin{array}{l}\text { Extensive experience with a } \\
\text { wide variety of multimedia for } \\
\text { remote training. Leaders in } \\
\text { Army application of } \\
\text { asynchronous computer } \\
\text { conferencing. }\end{array}$ & $\begin{array}{l}\text { Reserve } \\
\text { component-wi } \\
\text { de range of } \\
\text { skills and } \\
\text { knowiedge, } \\
\text { from BNCOC } \\
\text { to Advanced } \\
\text { training. }\end{array}$ & Army owned. & $\begin{array}{l}\text { Looking extensively at } \\
\text { dual use and } \\
\text { repurposing of } \\
\text { existing materials. }\end{array}$ \\
\hline
\end{tabular}




\begin{tabular}{|c|c|c|c|c|c|}
\hline $\begin{array}{l}\text { Institution or } \\
\text { Facility }\end{array}$ & $\begin{array}{l}\text { Point of } \\
\text { Contact }\end{array}$ & Brief Description & $\begin{array}{l}\text { Audience/ } \\
\text { Types of } \\
\text { Needs }\end{array}$ & Ownership & Special Notes \\
\hline $\begin{array}{l}\text { Army Logistics Management } \\
\text { College, Fort Lee, VA. }\end{array}$ & $\begin{array}{l}\text { Kenneth A. Johnson } \\
(804) 765-4004\end{array}$ & $\begin{array}{l}\text { Extensive 1-way satellite, } 2 \text { - } \\
\text { way audio instruction. } \\
\text { Several studios. Train } \\
\text { instructors in distance } \\
\text { learning teaching methods. }\end{array}$ & $\begin{array}{l}\text { Logistics related } \\
\text { training. } \\
\text { Further } \\
\text { research is } \\
\text { needed. }\end{array}$ & $\begin{array}{l}\text { Army owned studios } \\
\text { and broadcasting } \\
\text { equipment. }\end{array}$ & $\begin{array}{l}\text { Noted instructor } \\
\text { training course. }\end{array}$ \\
\hline $\begin{array}{l}\text { Army Professional Training, } \\
\text { Fort Eustis, VA. }\end{array}$ & & $\begin{array}{l}\text { HQ for network for satellite } \\
\text { training (2-way video and } \\
\text { audio) called VTT. }\end{array}$ & $\begin{array}{l}\text { Broad range of } \\
\text { content. }\end{array}$ & $\begin{array}{l}\text { Army owned studios, } \\
\text { equipment, and } \\
\text { satellite time. }\end{array}$ & Top of the line. \\
\hline $\begin{array}{l}\text { Army Field Artillery School } \\
\text { (Fort Sill) }\end{array}$ & $\begin{array}{l}\text { Johnsie Brown, } \\
\text { Director, Training } \\
\text { Development, } \\
\text { USAFAS, Fort Sill, } \\
\text { OK }\end{array}$ & $\begin{array}{l}\text { Extensive use of VTT. Also } \\
\text { multimedia learning center } \\
\text { adjacent to satellite classroom. }\end{array}$ & $\begin{array}{l}\text { Field Artillery } \\
\text { training } \\
\text { including new } \\
\text { equipment team } \\
\text { training. }\end{array}$ & $\begin{array}{l}\text { Army owned } \\
\text { resources. }\end{array}$ & $\begin{array}{l}\text { Creative distributed } \\
\text { training concepts. }\end{array}$ \\
\hline $\begin{array}{l}\text { National Defense University- } \\
\text { Information Resources } \\
\text { Management College (NDU-IRM) }\end{array}$ & $\begin{array}{l}\text { Al Luke, Director } \\
\text { Distance Education, } \\
\text { NDU, Ft. McNair, } \\
\text { Washington, D.C. } \\
\text { 20319-6000 } \\
\text { (202) 287-9317 also } \\
\text { Donita McGeary } \\
\text { (202) 287-9314 }\end{array}$ & $\begin{array}{l}\text { Beautiful facility situated at } \\
\text { Fort McNair. Teaches } \\
\text { advanced officer education } \\
\text { program courses in } \\
\text { Information Resource } \\
\text { Management and Information } \\
\text { Warfare. }\end{array}$ & $\begin{array}{l}\text { Majors through } \\
\text { Generals. } \\
\text { Information } \\
\text { resource } \\
\text { management, } \\
\text { decision- } \\
\text { making, and } \\
\text { information } \\
\text { warfare. }\end{array}$ & $\begin{array}{l}\text { Army owned facility } \\
\text { and equipment. } \\
\text { Faculty are hired full- } \\
\text { time. }\end{array}$ & \\
\hline $\begin{array}{l}\text { Defense Acquisition University } \\
\text { (DAU), } \\
\text { Room 422, } \\
2001 \text { N. Beauregard St. } \\
\text { Alexandria, VA 22311-1772 }\end{array}$ & $\begin{array}{l}\text { Frank Sobieszczyk, } \\
\text { Director for } \\
\text { University } \\
\text { Operations, } \\
\text { (703) } 845-6763 \text { or } \\
\text { Lenore E. Saltman } \\
\text { (703) } 845-6767\end{array}$ & $\begin{array}{l}\text { Virtual university consisting } \\
\text { of small staff who define } \\
\text { competencies, contract } \\
\text { courses, prioritize attendance } \\
\text { requests. Studying distance } \\
\text { learning options. }\end{array}$ & $\begin{array}{l}\text { All DOD } \\
\text { civilians, } \\
\text { contractor, } \\
\text { military } \\
\text { personnel that } \\
\text { have acquisition } \\
\text { responsibilities. }\end{array}$ & $\begin{array}{l}\text { Currently contract for } \\
\text { all resources. }\end{array}$ & $\begin{array}{l}\text { Notable methods for } \\
\text { determining } \\
\text { competencies. Very } \\
\text { rapid response to } \\
\text { congressional } \\
\text { mandate. }\end{array}$ \\
\hline
\end{tabular}




\begin{tabular}{|c|c|c|c|c|c|}
\hline $\begin{array}{l}\text { Institution or } \\
\text { Facility }\end{array}$ & $\begin{array}{l}\text { Point of } \\
\text { Contact }\end{array}$ & Brief Description & $\begin{array}{l}\text { Audience/ } \\
\text { Types of } \\
\text { Needs }\end{array}$ & Ownership & Special Notes \\
\hline $\begin{array}{l}\text { Navy Health Science Education } \\
\text { Training Command, } \\
\text { Biomedical Communications } \\
\text { Management Department, } \\
\text { Attn: Code } 42 \\
8901 \text { Wisconsin Avenue, } \\
\text { Bethesda, MD } 20889-5612 \\
\text { (301) 295-5757 }\end{array}$ & $\begin{array}{l}\text { Lt James Studebaker } \\
\text { (301) 295-5757 }\end{array}$ & $\begin{array}{l}\text { Develops over } 400 \text { medical } \\
\text { multimedia and delivers } \\
\text { worldwide to Navy Medical } \\
\text { Personnel. }\end{array}$ & $\begin{array}{l}\text { All Navy } \\
\text { Medical } \\
\text { technicians } \\
\text { through world. }\end{array}$ & $\begin{array}{l}\text { Navy owned } \\
\text { materials. Contractor } \\
\text { support in } \\
\text { development. }\end{array}$ & $\begin{array}{l}\text { Moving from IVD to } \\
\text { CD-ROM. }\end{array}$ \\
\hline Naval Training Systems Center & $\begin{array}{l}\text { Ed Salas, } 12350 \\
\text { Research Parkway, } \\
\text { Orlando, FL } \\
\text { (407) 380-4651 }\end{array}$ & $\begin{array}{l}\text { Researching team training } \\
\text { methodologies simulation } \\
\text { fidelity requirements. }\end{array}$ & General R\&D. & Contracts support. & $\begin{array}{l}\text { Cutting edge in group } \\
\text { and cognitive areas. }\end{array}$ \\
\hline $\begin{array}{l}\text { Dow Chemical } \\
\text { Employee Development Center } \\
\text { (EDQP) } \\
\text { Midland, MI } 48640\end{array}$ & $\begin{array}{l}\text { Randy Jensen (517) } \\
636-0598\end{array}$ & $\begin{array}{l}\text { Advanced learning classroom } \\
\text { facility in Midland, Michigan. } \\
\text { Designed for professional type } \\
\text { educational courses. }\end{array}$ & $\begin{array}{l}\text { Management } \\
\text { training and } \\
\text { advanced } \\
\text { technical } \\
\text { training. }\end{array}$ & $\begin{array}{l}\text { Contractor support in } \\
\text { developing. } \\
\text { Resources own by } \\
\text { Dow. }\end{array}$ & $\begin{array}{l}\text { Top of the line for } \\
\text { classroom technology. }\end{array}$ \\
\hline $\begin{array}{l}\text { Arthur Andersen \& Company } \\
\text { Training Center, } \\
1405 \mathrm{~N} \text {. 5th Avenue, } \\
\text { Saint Charles, IL } 60174\end{array}$ & $\begin{array}{l}\text { Keith Garland (708) } \\
444-4526\end{array}$ & $\begin{array}{l}\text { Large residence style facility } \\
\text { in St. Charles, } \\
\text { Illinois-houses } 1800 \\
\text { students. Provides initial } \\
\text { education for new hires, } \\
\text { continuing education and } \\
\text { customer training. }\end{array}$ & $\begin{array}{l}\text { Entry level, } \\
\text { continuing } \\
\text { education for } \\
\text { CPAs. }\end{array}$ & $\begin{array}{l}\text { Contractor support for } \\
\text { multimedia } \\
\text { development. } \\
\text { Facilities owned and } \\
\text { operated internally. }\end{array}$ & $\begin{array}{l}\text { Using multimedia for } \\
\text { powerful case-based } \\
\text { education. }\end{array}$ \\
\hline Motorola University & $\begin{array}{l}\text { Bill Wiggenhom, } \\
\text { President } \\
\text { Ed Callahan } \\
\text { (708) 538-32343 }\end{array}$ & $\begin{array}{l}\text { Teach generic courses that } \\
\text { apply company-wide. Also do } \\
\text { extensive development for } \\
\text { new corporate initiatives such } \\
\text { as quality, empowerment, and } \\
\text { re-engineering. Standard } \\
\text { classroom facilities. }\end{array}$ & $\begin{array}{l}\text { All employees, } \\
\text { management. }\end{array}$ & $\begin{array}{l}\text { Need more } \\
\text { information. }\end{array}$ & $\begin{array}{l}\text { Use training } \\
\text { organization as part of } \\
\text { change process. }\end{array}$ \\
\hline
\end{tabular}




\begin{tabular}{|c|c|c|c|c|c|}
\hline $\begin{array}{c}\text { Institution or } \\
\text { Facility }\end{array}$ & $\begin{array}{l}\text { Point of } \\
\text { Contact }\end{array}$ & Brief Description & $\begin{array}{l}\text { Audience/ } \\
\text { Types of } \\
\text { Needs }\end{array}$ & Ownership & Special Notes \\
\hline Tennessee Valley Authority & $\begin{array}{l}\text { Larry Durham, } \\
\text { Director of Training, } \\
\text { (615) } 751-6108\end{array}$ & $\begin{array}{l}\text { Four training facilitics next to } \\
\text { four nuclear power plants. } \\
\text { Include full-scope simulators. } \\
\text { Have gotten into multimedia } \\
\text { and have plans for distance } \\
\text { learning. }\end{array}$ & $\begin{array}{l}\text { Operator } \\
\text { training } \\
\text { (focused on) }\end{array}$ & $\begin{array}{l}\text { Developed } \\
\text { commercially. } \\
\text { Instructors, facilities } \\
\text { and equipment all } \\
\text { owned by TVA. }\end{array}$ & $\begin{array}{l}\text { Recognize importance } \\
\text { of an integrated } \\
\text { approach. }\end{array}$ \\
\hline $\begin{array}{l}\text { IBM Skill Dynamics Technical } \\
\text { Training Center }\end{array}$ & $\begin{array}{l}\text { William W. Johns, } \\
\text { Program } \\
\text { Administrator, Skill } \\
\text { Dynamics, an IBM } \\
\text { Company, 3100 } \\
\text { Windy Hill Road, } \\
\text { Marietta, GA } \\
300067 \\
\text { (404) 835-3524 }\end{array}$ & $\begin{array}{l}\text { Huge classroom and lab } \\
\text { building in Atlanta where they } \\
\text { train maintenance personnel } \\
\text { for all their computers from } \\
\text { PCs to Mainframes. }\end{array}$ & $\begin{array}{l}\text { Internal training } \\
\text { needs as well as } \\
\text { contractor } \\
\text { support at any } \\
\text { level. }\end{array}$ & $\begin{array}{l}\text { Own learning centers } \\
\text { nation wide, extensive } \\
\text { multimedia } \\
\text { courseware, and } \\
\text { major training center } \\
\text { visited. }\end{array}$ & $\begin{array}{l}\text { Huge number of } \\
\text { courses offered } \\
\text { platform or } \\
\text { multimedia. }\end{array}$ \\
\hline $\begin{array}{l}\text { Caterpillar Incorporated } \\
605 \mathrm{E} \text {. Springfield Ave. } \\
\text { Champaign, IL 61280 }\end{array}$ & $\begin{array}{l}\text { Kem Ahlars } \\
\text { (217) 244-5571 or } \\
\text { Orvill Raitt, or } \\
\text { Jim Helms } \\
\text { (309) 675-555 }\end{array}$ & $\begin{array}{l}\text { Providing extensive satellite- } \\
\text { based training to marketing } \\
\text { reps. Also developing and } \\
\text { distributing multimedia } \\
\text { training to customers on } \\
\text { maintenance of their } \\
\text { hardware. }\end{array}$ & $\begin{array}{l}\text { Intermal } \\
\text { training, } \\
\text { marketing } \\
\text { training, } \\
\text { customer } \\
\text { scrvice training. }\end{array}$ & $\begin{array}{l}\text { Own conferencing } \\
\text { capabilities. Develop } \\
\text { multimedia. }\end{array}$ & \\
\hline $\begin{array}{l}\text { Union Pacific Railroad } \\
210 \text { N. } 13 \text { th St. Rm } 1502 \\
\text { ST. Louis, MO } 63103\end{array}$ & $\begin{array}{l}\text { David Dwerlkotte, } \\
\text { Director of Program } \\
\text { Development \& } \\
\text { Systems Training } \\
\text { (314) 992-2333 }\end{array}$ & $\begin{array}{l}\text { Providing training on new } \\
\text { tracking system to blue-collar } \\
\text { workers using multimedia } \\
\text { learning stations in a dozen } \\
\text { learning centers. }\end{array}$ & $\begin{array}{l}\text { Skills } \\
\text { development. }\end{array}$ & $\begin{array}{l}\text { Contracted out } \\
\text { development. Own } \\
\text { all resources. }\end{array}$ & \\
\hline Shell Oil & & $\begin{array}{l}\text { Providing much the skill } \\
\text { training at an oil refinery } \\
\text { using multimedia learning } \\
\text { center. }\end{array}$ & $\begin{array}{l}\text { Skills } \\
\text { development. }\end{array}$ & $\begin{array}{l}\text { Own multimedia } \\
\text { equipment. }\end{array}$ & \\
\hline $\begin{array}{l}\text { 3M Corporate Technical Planning } \\
\text { and Coordination, } \\
\text { 3M Center, } \\
\text { Building 255-2N-01, } \\
\text { St. Paul, MN 55144-1000 }\end{array}$ & $\begin{array}{l}\text { John R. Humphrey, } \\
\text { Administrator, } \\
\text { Technical } \\
\text { Development, } \\
\text { (612) } 736-4772\end{array}$ & $\begin{array}{l}\text { Utilizing land-based video } \\
\text { conferencing as well as } \\
\text { extensive satellite reception to } \\
\text { provide continuing education } \\
\text { to engineers. }\end{array}$ & $\begin{array}{l}\text { Profession } \\
\text { development. }\end{array}$ & $\begin{array}{l}\text { Buying courseware. } \\
\text { Own communications } \\
\text { links. }\end{array}$ & \\
\hline
\end{tabular}




\begin{tabular}{|c|c|c|c|c|c|}
\hline $\begin{array}{l}\text { Institution or } \\
\text { Facility }\end{array}$ & $\begin{array}{l}\text { Point of } \\
\text { Contact }\end{array}$ & Brief Description & $\begin{array}{l}\text { Audience/ } \\
\text { Types of } \\
\text { Needs }\end{array}$ & Ownership & Special Notes \\
\hline (3) & ?.. & \&.radentia. & & & \\
\hline $\begin{array}{l}\text { Brigham Young University } \\
\text { Provo, UT } 84601\end{array}$ & $\begin{array}{l}\text { Dane S. Rigby } \\
\text { (Independent Study) } \\
\text { (801) 378-2642 } \\
\text { Curtis Fawson } \\
\text { (Director, Imaging } \\
\text { Technology Center, } \\
\text { Media Services) } \\
\text { (801) 378-4437 }\end{array}$ & $\begin{array}{l}\text { Several multimedia equipped } \\
\text { classrooms. Some with rear } \\
\text { projection, others with two } \\
\text { ceiling mounted video } \\
\text { projectors. Learning labs. } \\
\text { Continuing education. }\end{array}$ & $\begin{array}{l}\text { Students on } \\
\text { campus and } \\
\text { taking } \\
\text { correspondence. }\end{array}$ & $\begin{array}{l}\text { All classroom } \\
\text { improvements done } \\
\text { through intemal } \\
\text { consulting. }\end{array}$ & \\
\hline $\begin{array}{l}\text { Utah State University } \\
\text { Dept of Instructional Technology } \\
\text { D2 Research } \\
\text { Logan, UT 84322-2830 } \\
\text { Center for Persons With } \\
\text { Disabilities }\end{array}$ & $\begin{array}{l}\text { M. David Merrill } \\
\text { (801) 750-2779 } \\
\text { Andrew Gibbons } \\
\text { (801) 750-2393 } \\
\text { Steven Soulier (801) } \\
750-2653 \text {, Nathan } \\
\text { Smith } \\
\text { Alan M. Hofmeister } \\
\text { Director, } \\
\text { Technology } \\
\text { Division, (801) 750- } \\
\text { 3718 }\end{array}$ & $\begin{array}{l}\text { Leaders in instructional theory } \\
\text { and in finding ways to reduce } \\
\text { costs of multimedia } \\
\text { development. Have several } \\
\text { multimedia projects and a } \\
\text { multimedia presentation only } \\
\text { classroom. }\end{array}$ & $\begin{array}{l}\text { Students in } \\
\text { college of } \\
\text { education. }\end{array}$ & $\begin{array}{l}\text { Learning centers } \\
\text { managed by full-time } \\
\text { staff. }\end{array}$ & \\
\hline $\begin{array}{l}\text { Florida State University, } \\
\text { Center for Educational } \\
\text { Technology, } \\
406 \text { Milton Carothers Hall, } \\
\text { Tallahassee, FL 32306-4018 }\end{array}$ & $\begin{array}{l}\text { Robert K. Branson, } \\
\text { David Salisbury, and } \\
\text { Owen Gaede (904) } \\
644-1651\end{array}$ & $\begin{array}{l}\text { Developing prototype } \\
\text { instructor and student } \\
\text { electronic performance } \\
\text { support systems using } \\
\text { wireless pen-based } \\
\text { technology. }\end{array}$ & $\begin{array}{l}\text { K-12 schools, } \\
\text { primarily. }\end{array}$ & $\begin{array}{l}\text { Have found and are } \\
\text { looking for co- } \\
\text { development partners } \\
\text { for learning/ teaching } \\
\text { tools. }\end{array}$ & $\begin{array}{l}\text { Deeply involved in } \\
\text { long-term, systems } \\
\text { thinking and cognitive } \\
\text { engineering. }\end{array}$ \\
\hline $\begin{array}{l}\text { University of Central Florida, } \\
\text { Institule for Simulation and } \\
\text { Training, } \\
3280 \text { Progress Drive, } \\
\text { Orlando, FL 32826-0544 } \\
\text { (407) 658-5000 }\end{array}$ & $\begin{array}{l}\text { Mike Campion, } \\
\text { Peter Kincaid, } \\
\text { Neill Foshee, } \\
\text { Military Training } \\
\text { Specialist, } \\
\text { (407) 658-5057 }\end{array}$ & $\begin{array}{l}\text { Model high tech classroom } \\
\text { with multimedia projection, } \\
\text { group interaction via } \\
\text { computer at each desk. }\end{array}$ & $\begin{array}{l}\text { Government } \\
\text { and military } \\
\text { agencies. }\end{array}$ & $\begin{array}{l}\text { Develop prototype } \\
\text { courses and } \\
\text { equipment. Support } \\
\text { simulation studies. }\end{array}$ & $\begin{array}{l}\text { Wide range of } \\
\text { integrated high-tech } \\
\text { skills. }\end{array}$ \\
\hline
\end{tabular}




\begin{tabular}{|c|c|c|c|c|c|}
\hline $\begin{array}{l}\text { Institution or } \\
\text { Facility }\end{array}$ & $\begin{array}{l}\text { Point of } \\
\text { Contact }\end{array}$ & Brief Description & $\begin{array}{l}\text { Audience/ } \\
\text { Types of } \\
\text { Needs }\end{array}$ & Ownership & Special Notes \\
\hline $\begin{array}{l}\text { University of Florida, } \\
\text { Medical School } \\
\text { P.O. Box } 100294 \\
\text { Gainesville, FL 32610-0294 }\end{array}$ & $\begin{array}{l}\text { Douglas S. Richards, } \\
\text { M.D. } \\
\text { Assoc. Professor } \\
\text { (904) 392-2894 }\end{array}$ & $\begin{array}{l}\text { Utilize IVD to provide interns } \\
\text { with examples and CBT for } \\
\text { ultrasound and other specialty } \\
\text { areas. Priceless video clips } \\
\text { were captured over many } \\
\text { years of experience and show } \\
\text { a wide range of possible } \\
\text { situations Physicians may } \\
\text { face. }\end{array}$ & Interns. & $\begin{array}{l}\text { Source video comes } \\
\text { from own videotape } \\
\text { libraries. Use own } \\
\text { physicians to develop } \\
\text { content of hypermedia } \\
\text { lessons. }\end{array}$ & \\
\hline $\begin{array}{l}\text { University of Illinois, Urbana } \\
\text { Champaign, } \mathbb{L}\end{array}$ & $\begin{array}{l}\text { Rand Spiro } \\
\text { Prof, Inst affiliate, } \\
\text { Beckman, } \\
\text { Dept chair } \\
\text { (217) 333-2245 }\end{array}$ & $\begin{array}{l}\text { Several innovative multimedia } \\
\text { projects that teach complex } \\
\text { analysis and decisionmaking } \\
\text { skills }\end{array}$ & $\begin{array}{l}\text { Complex } \\
\text { problem- } \\
\text { solving. }\end{array}$ & $\begin{array}{l}\text { Developing authoring } \\
\text { tools. }\end{array}$ & $\begin{array}{l}\text { Innovative approach } \\
\text { for teaching complex } \\
\text { subject matter. }\end{array}$ \\
\hline $\begin{array}{l}\text { University of Maryland } \\
\text { College Park, MD } 20742\end{array}$ & $\begin{array}{l}\text { Ben Schneiderman, } \\
\text { Head of Human- } \\
\text { Computer } \\
\text { Interaction Lab. } \\
\text { ben@cs.umd.edu } \\
\text { also Theo Stone } \\
\text { (301) 405-2977 } \\
\text { ts65@umail.umd.edu }\end{array}$ & $\begin{array}{l}\text { Two high-tech classrooms. } \\
\text { Designed by group of } \\
\text { computer scientipto, cognitive } \\
\text { scientists, and media experts, } \\
\text { have created and use regularly } \\
\text { teaching theaters with } \\
\text { computers for each student. } \\
\text { Very interactive classroom- } \\
\text { based multimedia } \\
\text { environment. }\end{array}$ & Students. & $\begin{array}{l}\text { Donated equipment } \\
\text { (grants from AT\&T } \\
\text { and IBM). Instructors } \\
\text { are faculty members. }\end{array}$ & $\begin{array}{l}\text { Exciting application of } \\
\text { groupware and } \\
\text { cognitive engineering. }\end{array}$ \\
\hline $\begin{array}{l}\text { Learning Technology Center, } \\
\text { Cognition and Technology Group, } \\
\text { Vanderbilt University }\end{array}$ & $\begin{array}{l}\text { John Branson, } \\
\text { Director, Box } 45 \\
\text { Peabody College, } \\
\text { Nashville, TN } 37203 \\
\text { (615) 322-8070 } \\
\text { Olin Campbell Box } \\
3212 \\
(615) \text { 322-8414 }\end{array}$ & $\begin{array}{l}\text { Group of computer scientists } \\
\text { (AD), cognitive scientists, and } \\
\text { media experts, creating highly } \\
\text { interactive group-based } \\
\text { multimedia learning tools. } \\
\text { Effectively teach math and } \\
\text { soft skills using media } \\
\text { support. }\end{array}$ & $\begin{array}{l}\text { Primary school } \\
\text { age math skills, } \\
\text { college level } \\
\text { teaching of soft } \\
\text { skills. }\end{array}$ & $\begin{array}{l}\text { Do own curriculum } \\
\text { development. Own } \\
\text { studios and intermal } \\
\text { expertise. }\end{array}$ & \\
\hline
\end{tabular}




\begin{tabular}{|c|c|c|c|c|c|}
\hline $\begin{array}{l}\text { Institution or } \\
\text { Facility }\end{array}$ & $\begin{array}{l}\text { Point of } \\
\text { Contact }\end{array}$ & Brief Description & $\begin{array}{l}\text { Audience/ } \\
\text { Types of } \\
\text { Needs }\end{array}$ & Ownership & Special Notes \\
\hline University of Pittsburgh, LRDC & $\begin{array}{l}\text { Alan Lesgold, } \\
\text { Learning Research } \\
\text { and Development } \\
\text { Center, University of } \\
\text { Pittsburg, Pittsburg, } \\
\text { PA }\end{array}$ & $\begin{array}{l}\text { Group of computer scientists } \\
\text { (AD and cognitive scientists } \\
\text { creating intelligent tutors for } \\
\text { teaching complex } \\
\text { troubleshoot skills. }\end{array}$ & $\begin{array}{l}\text { Military } \\
\text { troubleshooters } \\
\text { (focused on) }\end{array}$ & $\begin{array}{l}\text { Internal technical } \\
\text { skills. }\end{array}$ & \\
\hline Northwestern University & $\begin{array}{l}\text { Roger Shrank, } \\
\text { Directory, Institute } \\
\text { for Learning } \\
\text { Sciences, } \\
\text { Northwestem } \\
\text { University }\end{array}$ & $\begin{array}{l}\text { Group of computer scientists } \\
\text { (A), cognitive scientists, and } \\
\text { media experts, creating highly } \\
\text { interactive group-based } \\
\text { multimedia leaming tools. }\end{array}$ & $\begin{array}{l}\text { Variety of } \\
\text { audiences } \\
\text { including K-12 } \\
\text { schools, } \\
\text { college-age } \\
\text { students, } \\
\text { customer } \\
\text { support, } \\
\text { professional } \\
\text { development. }\end{array}$ & $\begin{array}{l}\text { Extensive cognitive, } \\
\text { computer science, and } \\
\text { multimedia expertise. }\end{array}$ & \\
\hline
\end{tabular}




\section{APPENDIX C DEFINITIONS}

C-1

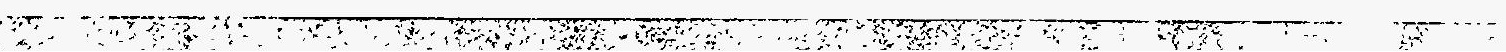




\section{APPENDIX C DEFINITIONS}

Analog Recording. Recording method in which the waveform of the recorded signal resembles the waveform of the original signal.

Analog Video. Video that is stored as an electrical signal with a continuous scale. Videotape and video disc generally store analog video.

ASCII (American Standard Code for Information Interchange). Established code that defines all characters, punctuation marks, and digits in binary form.

Authoring System. Computer program designed specifically to create computer-based instruction.

Bit (BInary digiT). Basic unit of computer information expressed numerically as O-zero or 1-one.

Branch. Movement from one location of a program to another. For example, if a button initiates a video disc sequence, it is said to branch to video.

Browse. In hypermedia, use of a completed hypermedia stack.

Button. Object in hypermedia used to initiate an action, such as a branch to another card or a video disc sequence.

Byte. Grouping of eight bits. A byte provides sufficient information to define one ASCII character.

Channel. Paths over which MIDI (Musical Instrument Digital Interface) information travels. MIDI can send data on as many as 16 channels with a single MIDI cable.

Compact Disc. Plastic platter 4.72 inches wide that stores digital data or music, encoded and read by laser beam. Sometimes called optical discs.

Compact Disc Audio (CD audio). Popular format for high-fidelity digital music. Each disc offers 74 minutes of programmable sound with no degradation of quality during playback.

Compact Disc Interactive (CD-I). System specification for an interactive audio, video and computer system based on compact disc as the storage medium. CD-I has a wide range of capabilities and is focused on the consumer market.

Compact Disc-Read Only Memory (CD-ROM). Prerecorded, nonerasable disc that stores over $650 \mathrm{MB}$ of digital data. It should be noted that the storage capacity of the CD-ROM will vary.

Compact Disc-Read Only Memory eXtended Architecture (CD-ROM XA). Special CD-ROM disc that interleaves the audio with the graphics/text. 
Compression. Reduction of a signal's output level in relation to its input level to reduce storage requirements.

Dedicated Telephone Line. Normal telephone line that is reserved for telecommunications.

Dialog Box. Window that asks a question or allows users to input information.

Digital Recording. Method of recording in which samples of the original analog signal are encoded as bits and bytes.

Digital Video. Video stored in bits and bytes on a computer. It can be manipulated and displayed on a computer screen.

Digital Video Interactive (DVI). Technology for compressing and decompressing video and audio to create multimedia applications. DVI can store 72 minutes of full-motion video on a compact disc.

Digitizing. Process of converting an analog signal into a digital signal.

Disc. Usually, a video disc or compact disc. Computer diskettes are electromagnetic and referred to as disks (with a " $\mathrm{k}$ "). Video discs and other optical storage media are referred to as discs (with a "c").

Electronic Mail (E-mail). Mail or communications sent and received through electronic, nonpaper methods. Usually a mainframe, a LAN, or a BBS is the vehicle.

Ethernet. Network communications standard developed by Xerox. Data transmission speed is typically 10 megabits per second.

Fiber Optic Cable. Cable that contains a fine strand of glass-like material. Light, not electricity, is conducted through the cable.

Foreground Layer. In most hypermedia programs, screens have two layers, the background and the foreground. The foreground layer is unique to each screen and cannot be shared. Generally, the foreground layer is viewed as being transparent-any objects on the background layer will show through the foreground layer.

Full-Motion Video. Display of video frames at 30 frames per second.

Host Computer. Computer that is called when initiating telecommunications; may be a mainframe, LAN, BBS, or personal computer.

Hypermedia. Delivery of information through multiple connected pathways. Hypermedia allows users to branch seamlessly between text, graphics, audio, or video.

Hypermedia Program. Software program that provides seamless access to text, graphics, audio and video discs.

Interactive Video disc (IVD). Generally refers to ILevel III interactivity in which a computer is used to control the video disc player. 
Interface. Link between two components, such as a CD-ROM player and a computer.

Internet. Internet is the name for a group of worldwide information resources. The Internet can be considered as a worldwide connection of individual computer networks. The roots of the Internet lie in a collection of computer networks that were developed in the 1970s. They started with a network called the ARPANET that was sponsored by the United States Department of Defense. The original ARPANET has long since been expanded and replaced, and today its descendents form the global backbone of what we call the Internet. There is no surcharge to use Internet. The new name for Internet will be National Research and Education Network.

Level I Interactivity. Interactivity achieved when the video disc player is controlled through the player, a remote control, or a barcode reader. The player is not connected to a computer.

Level II Interactivity. Interactivity achieved when the video disc contains a control program as well as the video material. The player is not connected to a computer.

Level III Interactivity. Interactivity achieved when a computer is used to control the video disc player.

Link. Connection from one place or medium to another. For example, buttons contain the linking information between cards in hypermedia.

Local Area Network (LAN). Interlinked microcomputer system, the dimensions of which are usually less than two miles. Transmission rates are usually above one megabit per second.

Modem (MOdulator-DEModulator). Device used to link computers together through telephone lines. Modulation is the process of changing computer data into tones that can be sent through a telephone line, and demodulation is the process of changing the tones back into computer data.

Multimedia. In its narrowest sense, "multimedia" means the integration of two or more media with a personal computer. The media list includes audio, video, text, graphics, and animation. The latest technologies even add odors. The dynamic growth of many technologies, including the integration technologies that bring the diverse systems under the precise control of a personal computer, offer extremely powerful tools in many fields, especially education and training.

National Television Systems Committee (NTSC). Committee that formulated the United States television standard of 525 horizontal lines per frame at 30 frames per second.

Object. In hypermedia, generally refers to an element placed on the screen, such as a button, field, or graphic. Objects are components that can be manipulated and can contain links to other objects.

Optical Disc. Disc encoded and read with a beam of light. Usually refers to a compact disc or video disc.

Optical Media. Media read with a laser beam. CD-ROM and video disc technologies utilize optical media for storage. 
Overlay. Ability of a computer and monitor to place a computer-generated graphic on top of a video display.

Personal Digital Assistant. A small, hand-held device that combines computer power with graphics, sound, video, and communications capabilities. They can take several forms including electronic note takers and portable display telephone. They hold various programs, address files, and databases depending on the user's needs. Many feature a modem, fax, radio mail, and computer.

Photo CD (Photographic Compact Disc). Disc used by Kodak to store photographic images.

Protocol. In telecommunications, complete structure of information going from one modem to the other. Data speed in bits per second, error checking, the number of start bits, the number of data bits, and the number of stop bits all constitute the protocol. The same settings must be used in both computer modems.

QuickTime. File format that allows Macintosh computers to compress and play digitized video movies.

Rewritable Compact Disc. Computer drive that allows the user to write, erase and rewrite on a compact disc (a developing technology).

Slide Show (Electronic). Computer screens designied in a sequence for projection purposes. Many hypermedia programs provide transitional effects for these sequences (such as dissolves or wipes).

Stack. In hypermedia, a group of cards in the same file, usually based on the same theme.

Still Video. Camera that stores pictures on a small diskette instead of film. The pictures can be displayed on a video monitor or can be digitized and displayed on a computer.

Telecommunication Software. Program used to allow the computer to communicate through a modem. Most software of this type dials the requested number and sets the modem for the system being called.

Terminal Emulation. Most mainframe computers are designed to communicate with specific workstations called terminals. For a microcomputer to communicate with a mainframe, the microcomputer telecommunication software must be able to perform as, or emulate, an appropriate terminal.

Token Ring. Network standard that uses a ring topology with token-passing techniques to prevent data collisions. Transmission rates are 4 or 16 megabits per second, depending upon interface cards and type of cable.

Twisted-Pair Cable. Two wires twisted together. This type of cable is often used for telephone communications.

Uniform Resource Locator (URL). The specification that defines the method of encoding for specific access protocols, as defined by the Internet Engineering Task Force (IETF) URL Working Group and was edited by various people in the Internet community. The specification basically describes how to access information on the Internet (i.e., what protocol to use), on 
which computer (on the Internet) it is located, and in which file and/or directory on that computer. This specification is not stable yet, however it does describe present-day practice used by World Wide Web information providers.

Workstation. Unit, consisting of a computer and peripherals, used to deliver lessons or provide a work area.

World Wide Web (WWW). A networked, information delivery system that presents information in hypdermedia-based format. The World Wide Web displays pages of information with links to other pages, images, video clips, and sound clips. The World Wide Web was originally developed by the European Laboratory Particle Physics (CERN) located near Geneva, Switzerland and France.

WORM (Write Once-Read Many). Special technology that can record (but not erase) a compact disc. 